UNIVERSIDADE DE SÃO PAULO

FACULDADE DE FILOSOFIA, LETRAS E CIÊNCIAS HUMANAS

DEPARTAMENTO DE LETRAS ORIENTAIS

PROGRAMA DE PÓS-GRADUAÇÃO EM LITERATURA E CULTURA RUSSA

MARIA PETROVA

\title{
A poética do romance gótico na coletânea Noites em uma granja perto de Dikanka de N.V. Gógol
}

São Paulo

2016 
LOMBADA

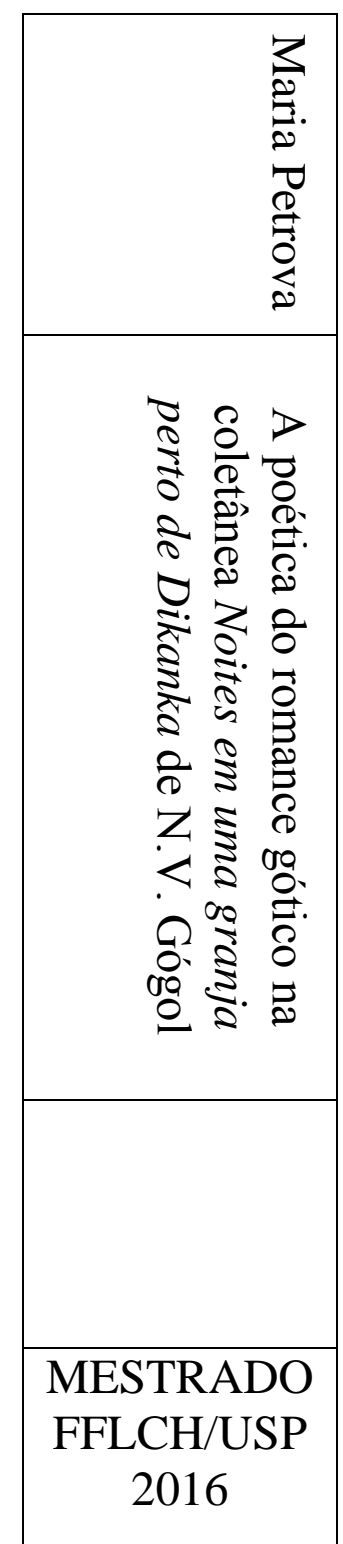


UNIVERSIDADE DE SÃO PAULO

FACULDADE DE FILOSOFIA, LETRAS E CIÊNCIAS HUMANAS

DEPARTAMENTO DE LETRAS ORIENTAIS

PROGRAMA DE PÓS-GRADUAÇÃO EM LITERATURA E CULTURA RUSSA

\section{A poética do romance gótico na coletânea Noites em uma granja perto de Dikanka de N.V. Gógol}

Dissertação apresentada ao Programa de PósGraduação em Literatura e Cultura Russa do Departamento de Letras Orientais da Faculdade de Filosofia, Letras e Ciências Humanas da Universidade de São Paulo, como exigência parcial para a obtenção do título de Mestre em Letras.

Orientadora: Profa. Dra. Arlete Orlando Cavaliere Ruesch

São Paulo

2016 
Autorizo a reprodução e divulgação total ou parcial deste trabalho, por qualquer meio convencional ou eletrônico, para fins de estudo e pesquisa, desde que citada a fonte.

Catalogação na Publicação

Serviço de Biblioteca e Documentação

Faculdade de Filosofia, Letras e Ciências Humanas da Universidade de São Paulo

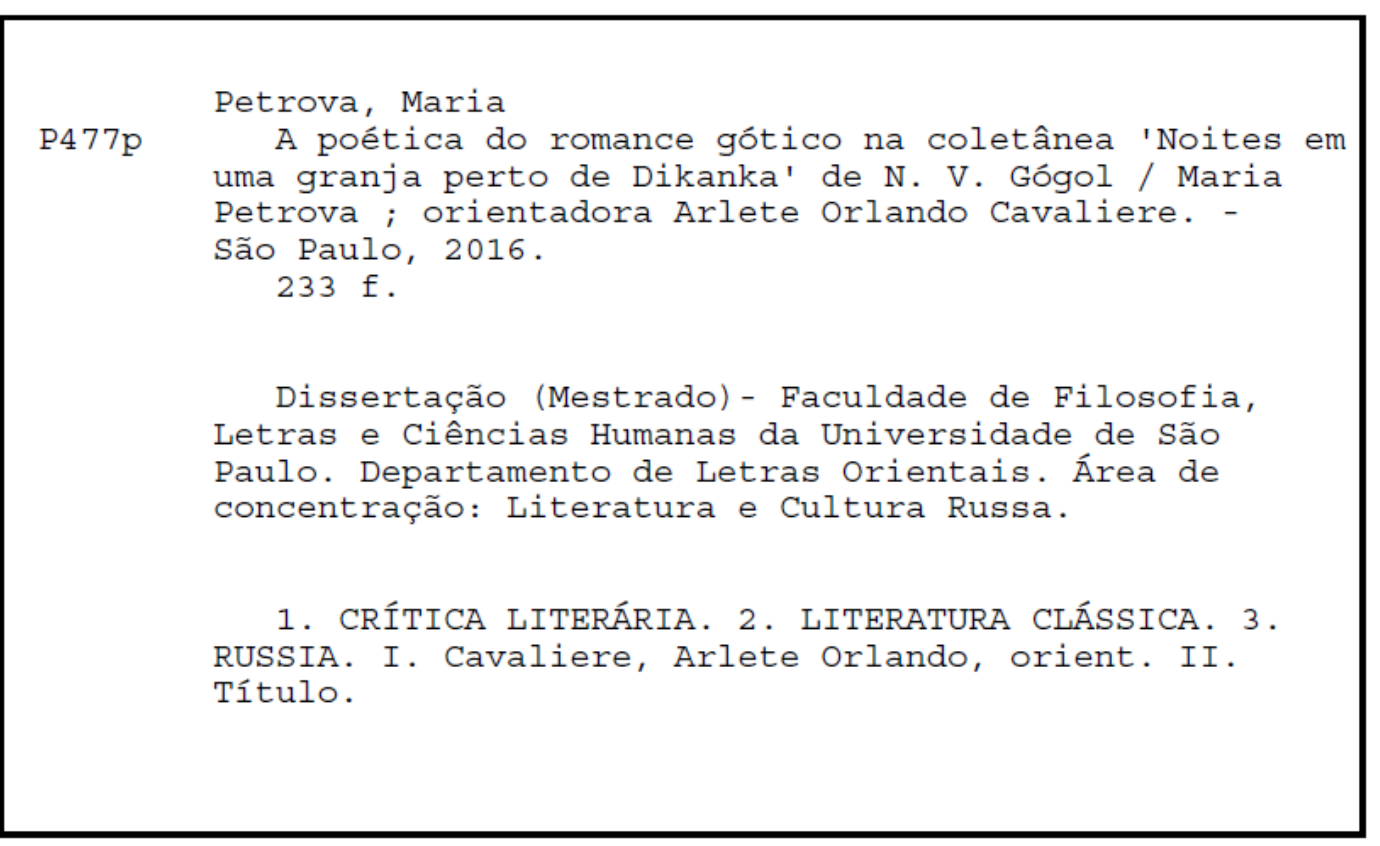




\title{
Folha de aprovação
}

\author{
Maria Petrova
}

A poética do romance gótico na coletânea Noites em uma granja perto de Dikanka de N.V. Gógol

Dissertação apresentada ao Programa de PósGraduação em Literatura e Cultura Russa do Departamento de Letras Orientais da Faculdade de Filosofia, Letras e Ciências Humanas da Universidade de São Paulo, como exigência parcial para a obtenção do título de Mestre em Letras

\section{Banca examinadora}

Prof. Dr.

Instituição: Assinatura:

Prof. Dr.

Instituição:

Assinatura:

Prof. Dr.

Instituição:

Assinatura:

Prof. Dr.

Instituição:

Assinatura:

Prof. Dr.

Instituição:

Assinatura:

São Paulo, de 2016 


\section{Agradecimentos}

À minha orientadora Profa. Dra. Arlete O. Cavaliere por ter sempre incentivado meu trabalho.

Aos meus amigos Giselle Mussi Moura e Filipe de Brito pela generosidade com que me ajudaram a esclarecer diversas dúvidas de tradução das novelas de Gógol para o português.

À minha amiga, doutoranda, Letícia Mei, que contibuiu para este trabalho com a versificação de um dos poemas gogolianos na novela Uma noite de maio, ou uma moça afogada.

À minha amiga Erivoneide Barros que me ajudou muito com a redação da dissertação.

Aos meus queridos alunos de russo, que, praticamente, financiaram esta pesquisa.

Aos meus pais, Margarita e Andrei Petróvy, que me apoiaram psicologicamente nos momentos mais difíceis. Sinto muito que o meu pai não sobreviveu até o final do meu mestrado.

Ao meu namorado, Nilo Almeida, que me inspirou e acompanhou essa pesquisa a cada passo com seu carinho e inteligência. 


\section{Resumo}

Duas coletâneas das novelas Noites em uma granja perto de Dikanka, de Nikolai Gógol (1809-1852), publicadas entre 1831 e 1832 e chamadas pelos pesquisadores de ucranianas, formaram o primeiro livro que trouxe o então jovem escritor à fama na sociedade literária russa. A obra, além de apresentar ao público o ainda pouco conhecido material etnográfico, ganhou destaque por formar uma complexa síntese das várias camadas literárias e culturais, colocando Noites dentro do sistema de várias oposições (romantismo/realismo; cristianismo/paganismo; catolicismo/ortodoxia, russo/europeu), sujeito à discussão até nossos dias.

Nesta dissertação, discute-se a possível conexão das obras de Nikolai Gógol, em especial as suas novelas ucranianas, com a poética do romance gótico inglês, gênero popular e difundido na Rússia no início do século XIX. Tal circunstância proporcionou o vasto uso e adaptação dos procedimentos típicos góticos pelos autores russos na época gogoliana. Para mostrar isso, são procurados e analisados os traços recorrentes do gênero em questão, que mostram a evolução e a transformação do gótico em um novo território e na poética de Gógol em particular.

Compõe, ainda, o volume desta dissertação a tradução de duas novelas gogolianas $-A$ noite da véspera do dia de Ivan Kupala (Vêtcher nakanune Ivana Kupala) e Uma noite de maio, ou uma moça afogada (Máiskaia notch', ili utóplennitsa). O critério de seleção dos textos em questão foi a presença marcante dos traços da tradição gótica.

Palavras-Chave:

Nikolai Gógol, Noites em uma granja perto de Dikanka, romance gótico, Rússia século XIX. 


\begin{abstract}
Two collections of tales Evenings on a farm near Dikanka, by Nikolai Gogol (18091852), published between 1831 and 1832 and named by the researchers "Ukrainian", formed the first book that brought a then young writer to fame in the Russian literary society. The work, aside from introducing to the public the yet little known ethnographic material, was highlighted for forming a complex synthesis of different cultural and literary layers, putting the Evenings into a system of various oppositions (romanticism/realism, Christianity/paganism, catholicism/orthodoxy, Russian/European), subject to a discussion until nowadays.

This dissertation discusses a possible connection of Gogol's works, especially his Ukrainian tales, with the poetics of English gothic romance, a popular and diffused genre in Russia in the beginning of the $\mathrm{XIX}^{\text {th }}$ century. That circumstance conditioned the widespread use and adaptation of typical Gothic devices by the Russian authors during the gogolian era. To prove that, our work researches and analyses the recurrent traces of the genre in question, that show the evolution and transformation of Gothic in the new territory in general and in Gogol's poetics in particular.

This dissertation also presents the translation into Portuguese of two Gogol's tales - St. John's Eve (Vecher nakanune Ivana Kupala) and May Night, or The Drowned Maiden (Mayskaya noch', ili Utoplennitsa). The selection criteria was the most outstanding presence of the Gothic traces in these texts.
\end{abstract}

Key Words:

Nikolai Gogol, Evenings on a farm near Dikanka, Gothic romance, Russia XIX ${ }^{\text {th }}$ century. 


\begin{abstract}
Аннотация
Два сборника повестей “Вечера на хуторе близ Диканьки”, впоследствии названные исследователями “украинскими”, были опубликованы Николаем Гоголем в 1831-1832 гг. Эта книга обеспечила молодому писателю первый успех в русском литературном обществе того времени. Помимо этнографического материала, представленного в книге и мало известного до этого широкой публике, в “Вечерах" впервые в гоголевском творчестве наметился сложный синтез различных культурных и литературных слоев, выразившийся в системе многочисленных оппозиций (романтизм/реализм, христианство/язычество, католичество/православие, русское/европейское). Их соотношение в произведениях автора является предметом дискуссии и по сей день.

В данной работе мы исследуем возможную связь произведений Гоголя с поэтикой английского готического романа - литературного жанра, имевшего широкое распространение в России в начале XIX века. Это обстоятельство обусловило творческую адаптацию типичных готических приемов среди российских авторов в гоголевскую эпоху. Мы изучаем и анализируем характерные особенности этого жанра, чтобы показать развитие и трансформацию готики на российской территории вообще и в поэтике Гоголя - в частности.

В диссертации также представлен перевод на португальский язык двух повестей Гоголя - "Вечер накануне Ивана Купала" и “Майская ночь, или утопленница". Критерием выбора этих произведений стало наиболее ярко выраженное присутсвие в них следов готической традиции.
\end{abstract}

Ключевые слова:

Николай Гоголь, “Вечера на хуторе близ Диканьки”, готический роман, Россия XIX века. 


\section{Sumário}

Introdução

Noites em uma granja perto de Dikanka: criação da obra, crítica da época e situação cultural na Rússia dos anos 30, do século XIX

\section{PARTE I}

Capítulo I. O romance gótico como um fenômeno literário 22

O primeiro romance gótico: Horace Walpole e $O$ castelo de Otranto (1764). 28

Outros autores góticos ingleses: Radcliffe, Lewis e Maturin..... 30

O impacto do gótico na cultura 33

Capítulo II. Recepção do gótico na Rússia 38

Alguns romances góticos russos 42

A Ilha Bornholm, de Nikolai Karamzin (1794). 42

O Couraceiro de Aleksandr Bestújev-Marlínski (1832). 45

Aleksandr Púchkin e o gótico 46

Capítulo III. A poética do gótico em Noites em uma granja perto de Dikanka de Nikolai Gógol

Gógol e o gótico: as pesquisas acerca do tema 49

O espaço gótico 55

O sistema dos narradores 82

Oposição herói/vilão 108

Gótico literário, arquitetura e artes plásticas: pontos de comparação. Transformação das imagens da arquitetura e pintura em Noites em uma granja perto de Dikanka temas recorrentes e figuras da linguagem 


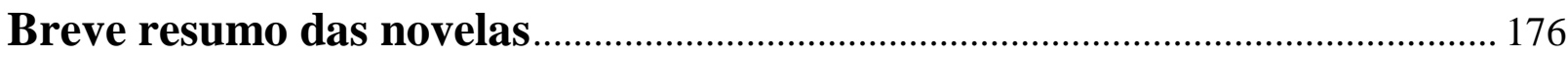

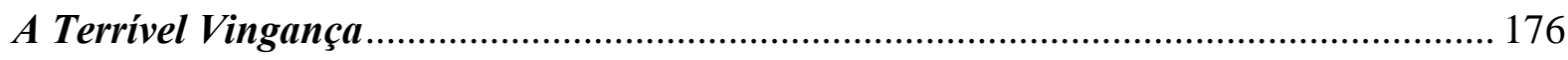

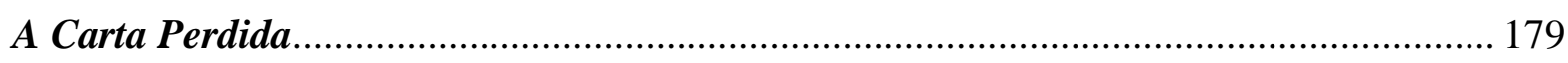

Novelas traduzidas para português.................................................................... 181

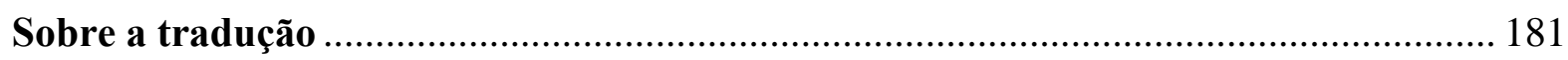

A Noite na véspera do dia de Ivan Kupala .......................................................... 183

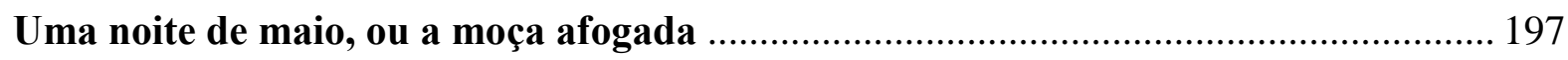

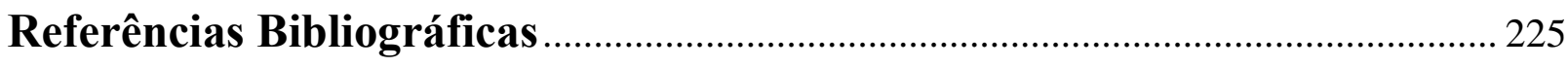




\section{Introdução}

Nikolai Gógol é considerado um dos escritores russos mais multifacetados do século XIX. Há, na sua obra, tantas camadas culturais, que até hoje ela está sujeita a interpretações diferentes. O escritor simbolista russo do século XX, Andrei Bélyi, assim comentou sobre este fenômeno: "Gógol é um gênio do qual não se pode aproximar com uma definição escolar. Eu tenho uma inclinação ao simbolismo, portanto é mais fácil para eu ver os traços de simbolismo de Gógol; o romântico vê nele um romântico, o realista - um realista"”.

Nas novelas ucranianas de Gógol, incluídas na coletânea Noites em uma granja perto de Dikanka, os críticos destacaram pelo menos três camadas principais: romântica, religiosa e folclórica; as duas últimas ligadas fortemente à primeira. Outros trabalhos revelam também os traços de barroco ${ }^{2}$, conectando a obra de Gógol ao teatro popular de vertep ${ }^{3}$ e a cultura não oficial medieval. Um dos primeiros a indicar o caráter profundamente barroco do estilo gogoliano foi, provavelmente, o historiador da literatura Andréi Siniávski, em seu renomado trabalho, Na sombra de Gógol. Segundo Siniávski,

Todas as feições e componentes deste estilo caprichoso que florescia na exposição europeia nos séculos XVI e XVII estão presentes em Gógol - se prestarmos atenção às suas composições abissais preferidas, que introduzem agitação e explosão em formas mais estagnantes, que puxam o espectador para suas gargantas abertas e expulsam, de volta, cascatas monstruosas de coisas; se prestarmos atenção às combinações, tradicionais para o barroco e próprias de Gógol, da escuridão exagerada, dificuldades da língua com suas construções lógicas e racionalismo retórico, sensualidade que cai na grosseria, com abstração especulativa na procura de fórmulas universais e sistemas

\footnotetext{
${ }^{1}$ BÉLYI, Andrei. Simvolizm kak miroponimánie. Moskvá: Respúblika, 1994. p. 365.

${ }^{2}$ Para saber mais sobre o tema, deixamos algumas referências a seguir: ARKHÍPOVA, I. V. Khudójestvennoe soznánie N.V. Gógolia $i$ estétika barokko. Tese de doutorado em filologia. Ekaterinburg, 2004; PARFIÓNOV, A.T. Gógol' $i$ barokko: “Igroki”. In Mirovoe drevo, 1996, n.4; CHAMBINAGO, S. Trilógiia romantizma (N. V. Gógol'). Moskvá, 1911; KALÁCHNIKOVA, O. L. Gógol' $i$ “drugoe” barokko: tol'ko li profetítcheski páfos?’'In VIKÚlOVA, V. P. (org.) N. V. Gógol' i sovreménnaia kul'tura: 6-e gógolevskie tchténiia. Moskvá: KDU, 2007; CHAPIRO, Gavriel. Nikolai Gogol' and the Baroque Heritage. In Slavic Review, Vol. 45 №1 (Spring 1986). pp. 95-104.

${ }^{3}$ CAVALIERE, Arlete. Teatro russo: percurso para um estudo da paródia e do grotesco. São Paulo: Humanitas, 2009. pp. 132-134.
} 
pesados que explicam com os métodos da neoescolástica todos os enigmas e mistérios $[\ldots]^{4}$.

Também o estudioso Gavriel Chapiro mostra numerosos contatos de Gógol com a cultura barroca. Ele surpreende os elementos do barroco por meio do rico uso de cores nos textos gogolianos, nos procedimentos estilísticos, como antítese e oxímoro, e nas frases massivas e luxuosas, mostrando, em seu artigo, como a educação de Gógol, no Liceu de Niéjin, ampliou seu conhecimento sobre os autores barrocos do século XVII e XVIII, entre os quais Luís Vaz de Camões e Torquato Tasso ${ }^{5}$. Segundo ele, durante toda a sua vida, Gógol estava profundamente interessado na literatura barroco russo-ucraniana eclesiástica ${ }^{6}$.

Considerando a multiplicidade de planos de análise de Noites, tentamos preencher as lacunas em mais um aspecto da poética gogoliana: a possível presença nesses textos dos traços da tradição do gótico. Como é difícil encontrar em Gógol uma temática dominante ao redor da qual gravitem outros aspectos ou elementos narrativos ${ }^{7}$, podemos dizer que o aspecto gótico é somente uma de suas numerosas facetas.

Nesta pesquisa, pretendemos nos restringuir à análise de quatro das oito novelas gogolianas da coletânea Noites em uma granja perto de Dikanka (1831-1832). São A Terrível Vingança, A noite da véspera do dia de Ivan Kupala, Uma noite de maio, ou uma moça afogada e A Carta Perdida. Como o foco da pesquisa é uma análise detalhada dessas novelas, relativamente desconhecidas no Brasil, faz-se necessário incorporar na dissertação os breves resumos dos textos já traduzidos e as traduções das novelas ainda não traduzidas ${ }^{8}$.

A presente dissertação contém, em sua introdução, uma breve história da criação da coletânea de novelas Noites em uma granja, com os comentários sobre a crítica e a situação cultural geral na Rússia do primeiro quartel do século XIX. Nesse item, explica-se também a importância do gênero novela, associada à tradição literária europeia e ao nome de Giovanni Boccaccio. Na literatura russa, as novelas estão ligadas ao folclore eslavo e a tradição popular de "vetchêrnitsy" - encontros amistosos noturnos dos camponeses, em que os hóspedes contavam as histórias sobre os encontros com o sobrenatural.

\footnotetext{
4 TERTS, Abram. $\quad V \quad$ teni $\quad$ Gógolia. Disponível em: <http://modernlib.ru/books/arzhak_nikolay_terc_abram/v_teni_gogolya/read>. Acesso em: 13 mai. 2015.

${ }^{5}$ CHAPIRO, 1986, p. 98.

${ }^{6}$ Esses estudos enriquecem a nossa análise dos traços góticos em Gógol, porque o barroco é um dos estilos que influenciou fortemente o gênero literário em questão.

${ }^{7}$ CAVAliERE, Arlete. A magia das máscaras. In GÓGOL, N.V. O nariz e a A Terrível Vingança. São Paulo: Editora da Universidade de São Paulo, 1990. p. 95.

${ }^{8}$ Ver no final da dissertação, a partir da p. 174.
} 
A primeira parte da presente dissertação propõe uma breve descrição da poética do romance gótico inglês e mostra as novidades que este gênero introduziu na literatura mundial; observa a influência e a adaptação do gótico na Rússia do primeiro quartel do século XIX e usa, como exemplos, algumas obras dos escritores russos próximos dessa tradição literária ${ }^{9}$; finalmente, vincula Noites em uma granja de Gógol com o gótico, destaca alguns momentos da biografia do autor relacionados ao assunto, e tenta localizar e fazer um breve comentário de alguns traços góticos nas novelas ucranianas. Já a segunda parte deste trabalho é dedicada à tradução de duas novelas gogolianas, pela primeira vez, traduzidas diretamente do russo.

Tendo surgido no final do século XVIII, o romance gótico inspirou numerosos autores em todos os países europeus, fazendo-os questionar e examinar os valores morais tradicionais; abordar de um modo novo o tema do bem e do mal, explorar mais objetivamente as virtudes e os vícios humanos, usando para isso, como instrumento principal, o fantástico e o insólito. $\mathrm{O}$ intuito do primeiro capítulo deste trabalho é descrever, brevemente, de acordo com o seu aparecimento cronológico, algumas das obras dos autores góticos ingleses mais importantes, focando os textos que influenciaram particularmente a cultura russa - entre eles os romances de Ann Radcliffe e Charles Maturin.

O segundo capítulo, ao se ocupar da recepção do romance gótico na Rússia do início do século XIX, procurou explicar as possíveis razões para a popularidade desse gênero em novo solo, entre as quais - uma atração forte pelo espírito de libertação e individualismo, particularmente, desejados pela sociedade russa após a revolta dos Dezembristas em 1825; a conexão profunda do gênero com as tragédias de Shakespeare, e uma ligação forte do gótico com o folclore e a mitologia. Para traçar a história do desenvolvimento do "romance de terror", na Rússia, contamos com a ajuda dos estudiosos russos e ingleses como V. Vatsuro, N. Tamártchenko, V. Málkina, E. Samoródnitskaia, S. Simpson, N. Cornwell, D. Punter entre outros.

A questão da refração da tradição gótica inglesa na literatura russa é, em primeiro lugar, uma questão de correspondência entre as duas culturas, uma questão de adaptação de algumas ideias inglesas no panorama eslavo. Pode-se dizer que, na Rússia, a tradição do gótico existia na consciência literária com contornos desfocados, com refrações dos motivos, das

\footnotetext{
${ }^{9}$ Parece-nos útil mencionar a definição de "tradição literária" feita por Iuri Tiniánov: "quando se fala da "tradição literária' ou de sucessão, costuma-se figurar apenas uma linha reta que une o representante mais jovem de um determinado ramo literário ao mais antigo. Mas, na realidade, a questão é muito mais complexa. Não se trata de uma linha reta contínua, mas antes de um ponto de partida, de um distanciamento de um determinado ponto; tratase de uma luta". Cf. "Dostoiévski i Gógol" (k teórii paródii") In. Avanguardia e tradizione. Bari: Ed. Dedalo libri, 1968, p. 135 (edição em italiano). In. CAVALIERE, 2009, p. 17, nota de rodapé 12. (citação em língua portuguesa).
} 
personagens e do cronotopo $^{10}$ góticos. O enfoque fica nas obras russas que possuem a semelhança tipológica com o gênero em questão: A Ilha Bornholm, de Karamzin, O Couraceiro, de Bestújev-Marlínski, e A dama de espadas, de Aleksandr Púchkin, obras bem conhecidas por Gógol.

O terceiro e último capítulo é reservado a uma análise minuciosa do aspecto gótico das novelas ucranianas de Nikolai Gógol. Inicialmente, mencionamos os escassos artigos dedicados ao tema "Gógol e o gótico" - os quais serviram como uma base inicial à nossa pesquisa. Em seguida, debruçamo-nos sobre questões específicas da poética do gótico na obra gogoliana. Para isso, descrevemos as peculiaridades de vários elementos que mostram o gótico em sua essência (o espaço, a narrativa, as personagens típicas, correlações textuais com a arquitetura), assim como os procedimentos característicos do gótico, tirando os exemplos abundantes das quatro novelas ucranianas; algumas, em um grau maior que outras, estão próximas ao romance de terror, e, por isso, são citadas com mais frequência.

A segunda parte destina-se, como já foi mencionado, à tradução. As duas novelas gogolianas - A noite da véspera do dia de Ivan Kupala e Uma noite de maio, ou a moça afogada - foram escolhidas com o objetivo de facilitar a análise dos traços góticos na obra do escritor e realizar uma breve amostra dos procedimentos góticos nos textos em questão. A primeira novela apresenta o enredo clássico para o romance gótico de uma sedução do homem pelo diabo e de sua queda moral. A segunda novela mostra os temas de maldição e vingança, ambos importantes para o gótico.

No final do trabalho, encontram-se as referências bibliográficas, divididas em três partes essenciais: obras de Nikolai Gógol, em português e russo, obras críticas acerca do tema em russo e obras críticas em outras línguas.

\footnotetext{
${ }^{10}$ Termo criado por Mikhail Bakhtin para definir a unidade do espaço e tempo e sua correlação na obra literária. No estilo gótico, existe uma correlação específica entre o espaço e o tempo, em que o passado, como uma categória temporal, tem presença física no espaço da obra.
} 


\title{
Noites em uma granja perto de Dikanka: criação da obra, crítica da época e situação cultural na Rússia dos anos 30, do século XIX
}

\author{
Deixa-o, usando uma velha talagarça, bordar os desenhos \\ novos e mostrar-nos em pequena moldura um quadro da \\ sociedade e das pessoas que ele conhece tão bem ${ }^{11}$.
}

(Aleksandr Púchkin, O Romance nas cartas, 1829).

As duas coletâneas de oito novelas Vetcherá na khútore bliz Dikanki (Noites em uma granja perto de Dikanka), chamadas pelos pesquisadores de folclóricas ou ucranianas, publicadas entre 1831 e 1832, formaram o primeiro livro que tornou famoso o então jovem Nikolai Gógol na sociedade literária russa. Esse livro levou-o ao sucesso como escritor prosaico; anteriormente, Gógol havia feito uma tentativa fracassada na poesia com o poema Hanz Kukhelgárten (publicado em 1829, sob o pseudônimo V. Álov). Mas esse texto, possuindo fortes traços da influência dos poetas alemães do século XVIII, especialmente de Johann Heinrich Voss e seus idílios, foi recebido com frieza pelos críticos literários e leitores fato que levou Gógol a comprar todos os livros da editora e queimá-los ${ }^{12}$. O escritor Vladímir Nabókov, comentando esse primeiro fracasso de Gógol, explica que "a jovialidade natural ucraniana de Gógol obviamente venceu o romantismo alemão ${ }^{13}$ ".

Tendo crescido na Ucrânia, Gógol, porém, escreveu toda a sua obra em russo - isso porque a Maloróssia $^{14}$, a região do seu nascimento, pertencia, naquela época, ao Império Russo. A língua russa, além de ser a única língua com estatuto legítimo no país, era também a única língua adequada para resolver todos os problemas universais criativos que o escritor enfrentava: "Gógol entendia muito bem que a posição oprimida da língua ucraniana no império, desde o início, o condena como um escritor a não ser ouvido em todo o espaço do império, sem mencionar o mundo inteiro. Pois ele media sua futura atividade exatamente com tais medidas -

\footnotetext{
11 PÚCHKIN, A. S. Roman v pis'makh. In GÓRKI, M. BLAGÓI, D., BONDI, S. et. al. (Org.). PÚCHKIN, A. S. Pólnoe sobránie sotchinénii v 16 tomakh, tomo VIII. Moskvá, Leningrad: AN SSSR, 1948. p.50.

${ }^{12}$ Para saber mais sobre a juventude de Gógol, recomendamos as seguintes fontes: VERESSÁEV, V.V. Gógol'v jizni:sistematitcheskii svod svidételstv sovreménnikov. Moskvá/Leningrad: Academia, 1933; ZOLOTÚSSKI, I. P. Gógol', 5a edição. Moskvá: Molodáia Gvárdiia, 2005.

${ }^{13}$ NABÓKOV, Vladímir. Gógol'. Disponível em: <http://gatchina3000.ru/literatura/nabokov_v_v/gogol.htm>. Acesso em: 7 mai. 2015.

${ }^{14}$ Maloróssia (literalmente: “a pequena Rússia”) - é o nome habitualmente aplicado a partes do atual território da Ucrânia, antes do século XX.
} 
mundiais, universais ${ }^{15}$ ". Mas, apesar disso, pode-se dizer que o caráter do seu talento possuía raízes fortes na cultura popular ucraniana. As duas fontes principais de inspiração para Noites em uma granja eram as impressões de sua infância, na Maloróssia, com histórias engraçadas e contos maravilhosos, narrados para ele por sua mãe e outros parentes, e a atividade literária de seu pai, que tinha escrito duas comédias em ucraniano.

Representação teatral do cotidiano, as cenas de farras, glutonaria, brigas, materiais folclóricos, o desenvolvimento do enredo de uma anedota, as personagens caricaturescas - tudo isso já fazia parte do teatro popular na juventude de Gógol, que, não por acaso, decidiu apresentar a rica cultura ucraniana ao público petersburguês: a sociedade literária russa, no início dos anos 1830, estava muito interessada na vida da sua colônia sudoeste, como o próprio Gógol tinha anotado em uma das cartas a sua mãe: Aqui todos são tão curiosos sobre tudo da Maloróssia $[\ldots]^{16}$.

No início dos anos 30, a obra do jovem autor, refletindo os caminhos complexos da cultura do século XIX, era um fenômeno romântico com seu dualismo e contradições absolutas. Noites em uma granja surgiu em um período de várias transições na literatura russa: os anos 1830 assinalaram o deslocamento da poesia à prosa, do romantismo ao realismo, do romance aos gêneros mais curtos. Um dos críticos de Gógol da época, Ándri Tzarynnyi, assim dizia a respeito desse fenômeno, em tom irônico:

Graças ao espírito do tempo [...], há muitos leitores russos agora; a literatura nacional não os satisfaz por completo, limitada por uma quantidade não muito grande de romances. Nossos escritores ociosos os alimentam com poeminhas, novelas leves e curtinhas, e, se alguém não estiver com preguiça de encher com tais obras, uns dois livrinhos, [...] a fraternidade o compara com os autores mais famosos da iluminada Europa ${ }^{17}$.

Foi exatamente isso que Gógol fez quando publicou os seus dois livros com as novelas folclóricas. Um observador atento desde jovem, o escritor percebeu as duas tendências principais do processo literário na Rússia de sua época: o interesse pelos gêneros prosaicos de

15 BARABACH, I. Chotlandsko-irlándskie paralleli $v$ gogolevédenii ukraínskovo zarubéj’ia. In MANN, I. V. (org.).Gógol' kak iavlénie mirovoi literatury. Moskvá: IMLI RAN, 2003. p. 358.

${ }_{16}$ GÓGOL, N. V. Pólnoe sobránie sotchinenii $v$ semí tomakh. Tomo I. In MACHÍNSKI S. I, KHRÁPTCHENKO M. B. (org.). Moskvá: Khudójestvennaia literatura, 1976. p. 58.

17 TZARYNNYI, Ándrii. Mysli malorossiiánina, posle protchténiia povestéi pásitchnika Rúdovo Panká, opublikóvannykh v knige pod nazvániem 'Vetcherá na khútore bliz Dikanki', i retsenzii na onye, Sankt-Peterburg: Tipográfiia N. Gretcha, 1832. p. 9. 
pequena extensão (especialmente, o conto [rasskaz] e a novela [póvest']) e uma tendência à ciclização, isto é, a tentativa dos autores formarem os ciclos das narrativas dentro de única obra $^{18}$. O mais famoso exemplo desses "ciclos" na literatura russa é uma obra de Aleksandr Púchkin (1799-1837), Póvesti Bélkina (Os contos de Belkin), publicada no mesmo ano que o primeiro volume de Noites ${ }^{19}$.

O gênero inicialmente atribuído a Noites - os "vetchêrnitsy" (encontros noturnos), mencionados por Gógol já no prefácio ao primeiro volume - era uma história, novela, narrada por uma pessoa a outras durante um encontro noturno amistoso ${ }^{20}$. Tal coletânea não foi a primeira desse tipo. Essa forma de narrativa tem suas raízes na mitologia e passou a ter um verdadeiro renascimento na Europa, na época do pré-romantismo. De acordo com o estudioso André Jolles ${ }^{21}$, o gênero novela existia desde o século XIV, quando foi publicada a obra consagrada de Giovanni Boccaccio, Decameron. Pouco depois do conjunto de obras de Boccaccio, as novelas chegaram a ser, normalmente, produzidas em duas variedades: em coletâneas ou isoladas.

As narrativas em coletâneas costumavam ser ligadas entre si por um quadro que assinalava "onde", "em que ocasião" e "por que" uma ou outra novela foi contada. Esse quadro, na tradição crítica, recebeu o nome de narrativa-moldura. Era típica para o gênero, desde aquela época, a tentativa de "contar um fato ou um incidente impressionante de maneira tal que se tenha a impressão de um acontecimento efetivo e, mais exatamente, a impressão de que esse incidente é mais importante do que as personagens que o vivem $22 \%$. A figura mais viva na obra era a do narrador, que dava à novela um caráter original e individual, interrompendo o enredo com comentários ou desvios explicativos que, além de retardar a ação, exerciam a função de ganchos sintáticos que desviavam o relato de seu curso normal, instituindo rupturas no plano da lógica verbal.

No início do século XIX, vários autores europeus usavam uma técnica de narrativa parecida. A máscara do narrador-contador tornou-se um lugar-comum na literatura europeia já no final dos anos 20 do século XIX. Essa técnica, por exemplo, é parte importante da

\footnotetext{
${ }^{18}$ EIKHENBAUM, Boris. O proze. Sbórnik statéi. Leningrad: Khudójestvennaia literatura, 1969. p. 250.

${ }^{19}$ Fato que, a propósito, exclui a possibilidade da influência do poeta em Gógol durante a criação de Noites.

${ }^{20} \mathrm{Na}$ novela A feira de Sorótchintsy, o editor da coletânea - o colmeeiro - diz: Mas, melhor que tudo, é quando todos se juntam num monte apertado e começam a propor adivinhas ou simplesmente bater papo. Meu Deus! O que eles não contarão! Quantas velhas estórias não lembrarão! Quantos medos não inspirarão!. In GÓGOL, 1976, tomo I, p. 8. Essa descrição, em nossa opinião, é uma boa tentativa do autor de formar seus critérios para este gênero literário.

${ }^{21}$ JOLLES, André. Formas simples: Legenda, Saga, Mito, Adivinha, Ditado, Caso, Memorável, Conto, Chiste. Trad. Álvaro Cabral. São Paulo: Ed. Cultrix. 1976.

${ }^{22}$ Idem, Ibidem, p. 189.
} 
composição do romance Frankenstein: or, The modern Prometheus (Frankenstein: ou $O$ Prometeu Moderno, 1818), de Mary Shelley; das coletâneas das novelas do escritor romântico E.T.A. Hoffmann, Die Serapionsbrüder (Os irmãos de Serapião, 1819-21); e de Tales of my lanlord (Os contos do meu senhorio, 1816-31), do criador do romance histórico, Walter Scott. $\mathrm{O}$ encontro noturno como elemento do enredo era também inevitável no gênero ghost story (conto de fantasmas), que surgiu na Inglaterra do século XVIII e que depois formou a "base sobrenatural" para o romance gótico.

Quanto à Rússia, alguns conjuntos de novelas chegaram a ser populares no final do século XVIII, quando saíram várias coletâneas, inclusive sob o título "Vetcherá" ("Noites"): Zabávnye vetcherá (As noites engraçadas, 1789), de Koz'ma Golubiánski, Krestiánskie skazki, ili dvenádtsat' vetcherov dliá preprovojdéniia prázdnovo vrémeni (Os contos camponeses, ou as doze noites para passar o tempo livre, 1790), cujo autor é desconhecido, e Vetchêrnie chassy (As horas noturnas, 1787-1788) de V. Lévchin. Os conjutos das novelas "noturnas" continuaram sendo publicados no século XIX: por exemplo, Slavênskie vetcherá (As noites eslavas, 1826), de V. T. Naréjnyi, e Noites em uma granja, de Nikolai Gógol ${ }^{23}$.

O interesse pelo folclore também não era novidade na literatura russa. Outros autores se ocuparam com frequência dos mesmos temas e assuntos ligados a certa tradição popular, efabulações nascidas das lendas populares e da demonologia, que estavam em voga no final do século XVIII. Já nos anos 1770, coletâneas dedicadas à cultura, história e aos costumes da Maloróssia foram publicadas em abundância, entre elas, de I. Márkovitch, Zapisski o Maloróssii (Os retratos da Maloróssia, 1798); P. Chálikov, Putechéstvie v Maloróssiiu (Viagem à Maloróssia, 1803); A. Lévchin, Piss'ma iz Maloróssii (Cartas da Maloróssia, 1816), e muitas outras ${ }^{24}$. Mas, embora abordassem o mesmo tema que Gógol, diferenciavam-se no foco narrativo.

Os autores oitocentistas, seguindo a ideia de enciclopedismo, foram simples descritores fiéis dos hábitos e costumes. No início da sua criação literária, Gógol pretendia seguir o mesmo plano. Em uma carta escrita à sua mãe, no início do ano de 1830, pedia-lhe que mandasse informações sobre a Maloróssia, isto é, as anedotas, os costumes, os hábitos e as crenças curiosas:

\footnotetext{
${ }^{23}$ KALÁCHNIKOVA, 2007.

${ }^{24}$ ZAMÁNOVA, I. F., Prostranstvo i vrémia v khudójestvennom mire sobrnika Gógolia “Vetcherá na khútore bliz Dikanki”. Tese de doutorado em letras. Oriól: Universidade de estado de Oriól, 2000.
} 
A senhora pode perguntar sobre os velhos tempos [...] quais vestidos os sótniks ${ }^{25}$, as suas esposas, os tysiatchniks ${ }^{26}$, [...] usavam no seu tempo, quais tecidos eram conhecidos no seu tempo, e tudo com o maior detalhe possivel; quais anedotas e casos engraçados, divertidos, tristes, horriveis aconteceram no seu tempo. Não ignore nada, tudo tem valor para mim $^{27}$.

$\mathrm{O}$ aspecto folclórico de Noites em uma granja correspondia às tendências literárias europeias daquela época. Cabe salientar que a coletânea de Gógol congregava "o romantismo alemão, com seus temas de feitiçaria a erigir um universo fantástico e grotesco, e o conto folclórico ucraniano, com a luta tradicional do homem com o diabo e a difícil vitória do bem

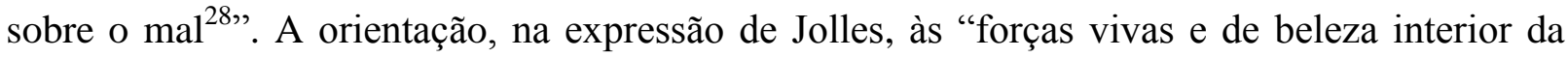
realidade popular nacional ${ }^{29,}$, era também característica da obra de Walter Scott, autor que sempre interessou a Gógol.

Mas, durante o processo criativo, Gógol não se concentrou na exatidão dos costumes populares: o folclore ucraniano misturou-se com a fantasia romântica, a prosa inclinou-se à poesia $^{30}$ - mesmo tendo fracassado com o poema, o escritor continuava sendo um poeta. As crenças pagãs foram modificadas pela profunda religiosidade do autor, formando uma obra complexa, diferente de tudo que tinha sido publicado antes na Rússia e introduzindo várias novidades para aliteratura russa.

Unidade na variedade. Cada uma das novelas de Noites em uma granja é independente das outras em relação ao enredo e, ao mesmo tempo, forma uma parte do mesmo mundo ficcional, unida pelo lugar dos acontecimentos, temas, as personagens e os narradores. No nível composicional, todas as novelas de Gógol formam um ciclo de acordo com o calendário das festas camponesas de origem pagã: começa com a feira de Sorótchintsy no início do outono, continua com a festa de Ivan Kupala em junho, seguida por koliady - as festividades pagãs associadas ao período de solstício de inverno que tradicionalmente acompanhavam o Natal, e

\footnotetext{
${ }^{25}$ Os chefes de centenas administrativo-territoriais ou militares na Ucrânia entre os séculos XVI e XVIII (Nota de trad.).

${ }^{26}$ Os chefes de milhares de militares na Ucrânia entre os séculos XVI e XVIII (Nota de trad.).

27 GÓGOL, N. V. Pólnoe sobránie sotchinenii $v$ semí tomakh. Tomo VII. In MACHÍNSKI S. I, KHRÁPTCHENKO M. B. (org.). Moskvá: Khudójestvennaia literatura, 1976. p. 62.

${ }^{28}$ CAVALIERE, 2009, p. 161.

${ }^{29}$ JOLLES, 1976, p. 182.

${ }^{30}$ Devemos mencionar aqui um texto interessante de ORLÍTSKI, I., Sillabo-tonitcheskii metr v proze Gógolia, in MANN (Org.), 2003. pp. 96-106. O estudioso fez uma análise textual de toda a obra gogoliana, inclusive seus artigos e cartas, e chegou à conclusão de que a prosa do escritor contém muitos trechos parecidos com os pés poéticos, especialmente as coletâneas Noites em uma granja e Mírgorod. Entre essas, as novelas mais "métricas", parecidas com o ritmo poético, são Uma noite de maio, A feira de Sorótchintsy e A Terrível Vingança. Isso mais uma vez comprova nossa ideia de que a obra do jovem Gógol reflete uma situação fronteiriça na literatura russa do início dos anos 1830, na qual a prosa e a poesia não foram completamente separadas uma da outra.
} 
termina com as festas das sereias (russálii) em maio. As personagens têm conexões familiares: em $A$ noite da véspera do dia de Ivan Kupala aparece "a tia do falecido avô", em A Carta Perdida e em Um lugar encantado, o protagonista é o falecido avô. Todos os narradores são membros do mesmo círculo reunido junto à mesa do colmeeiro.

O sistema dos narradores. O colmeeiro Rúdyi Pankó é apenas o editor das novelas, cada história tem seu próprio contador. Os narradores são divididos em dois grupos, que podem ser definidos como "os próprios" e "os estrangeiros". Os primeiros são associados ao mundo de Dikanka e representam seus valores. São o diácono Fomá Grigórievitch ( $A$ noite da véspera do dia de Ivan Kupala, A Carta Perdida, Um lugar encantado), o narrador sem nome de A Noite de Natal (alguns pesquisadores atribuem a autoria dessa novela ao colmeeiro), Stepan Kúrotchka (Ivan Fiódorovitch Chponka e sua tia) e o editor, cuja opinião e visão do mundo são definidas nos dois prefácios de Noites.

Opostos a esses, são os "estrangeiros" - portadores dos valores alheios. São o polonês de caftan cor verde-ervilha, Makar Nazárovitch (A feira de Sorótchintsy, Uma noite de maio, ou uma moça afogada) e o narrador sem nome de A Terrível Vingança, alcunhado por Rúdyi Pankó como "o escuro". Esses dois grupos de narradores, condicionalmente, representam os dois lados da obra gogoliana: a comicidade e o terror.

Os cinco narradores, com sua visão do mundo diferente e maneira peculiar de contar histórias, ajudam ao autor de Noites a criar uma impressão da multiplicidade dos pontos de vista e das visões do mundo. Todas as opiniões têm direito da existência, elas não contradizem, mas completam uma a outra. Assim o autor se aproxima do objeto de descrição ou visivelmente se afasta dele ${ }^{31}$. A análise mais escrupulosa das imagens dos narradores será feita no item "O sistema dos narradores" ${ }^{\prime 2}$.

Imitação da fala popular. A introdução dos narradores e as suas reflexões sobre os méritos do relato oral, assim como os seus pensamentos sobre as maneiras de contar histórias, mostram a orientação geral do autor ao caráter verbal da narração, o que aproxima Noites em uma granja da técnica do $\mathrm{skaz}^{33}$. Gógol não somente imita o discurso verbal nas novelas, mas recria as situações comunicativas diferentes para conferir a importância da fala popular para a coletânea inteira. Os seus heróis conversam, brigam, contam piadas, xingam, juram por Deus etc. $^{34}$

\footnotetext{
${ }^{31}$ ZAMÁNOVA, 2000, p. 41.

${ }^{32}$ Verificar o item nas pp. 80-105 da presente dissertação.

${ }^{33}$ Termo criado pelo formalista russo Boris Eikhenbaum, que significa introdução ampla dos elementos da fala popular na obra literária.

${ }^{34}$ SOFRÓNOVA, L. A. Mifopoètika ránnevo Gógolia. Sankt-Peterburg: Aleteiia, 2010. pp. 14-15.
} 
Mikhail Bakhtin considera o skaz como um método para mostrar o objeto de descrição sob uma nova luz: os pontos de vista dos narradores são limitados, mas produtivos em relação aos outros horizontes culturais (do autor e dos leitores). O autor, usando o discurso da outra personagem, não só mostra seu ponto de vista sobre aquele, sobre sua fala e sua linguagem, mas também sobre o objeto da narrativa. Assim, o leitor experimenta qualquer momento da narrativa em dois planos: o plano do narrador e seu horizonte, e o plano do autor, que está se expressando através dessa narrativa alheia ${ }^{35}$.

A composição de cada novela depende muito do tom pessoal do autor. De acordo com o formalista Boris Eikhenbaum, "a composição em Gógol não é definida pelo enredo - seu enredo é sempre pobre; é melhor dizer que não há enredo algum, e só é usada alguma situação cômica (ou até mesmo não cômica por si própria) que serve de impulso ou causa para o desenvolvimento dos modos cômicos ${ }^{36}$ ". Provavelmente não será correto falar em falta de enredo em Noites em uma granja, já que muitos dos enredos são parcialmente baseados em contos maravilhosos eslavos ${ }^{37}$. Todavia devemos concordar que o escritor, frequentemente, usava várias situações para, saindo do enredo principal, aplicar os modos da mímica oral, inventar as articulações cômicas, trocadilhos sonoros etc. - tudo para acentuar a figura do narrador, atrás do qual se escondia um ator. Na literatura russa, Gógol foi um dos primeiros a usar esse método narrativo.

\footnotetext{
35 BAKHTIN, M.M. Teóriia romana. In Pólnoe sobránie sotchinénii, v. III.Moskvá: Iazykí slaviánskikh kul'tur, 2012. pp. 126-127.

${ }^{36}$ EIKHENBAUM, 1969, p. 307.

${ }^{37}$ PETROVA, M. Proximidade dos contos ucranianos de Nikolai Gógol ao conto maravilhoso. In VIII Encontro de Letras Orientais e Eslavas, 2013, Rio de Janeiro. Caderno de Programação e Resumos do VIII Encontro de Letras Orientais e Eslavas, 2013.
} 


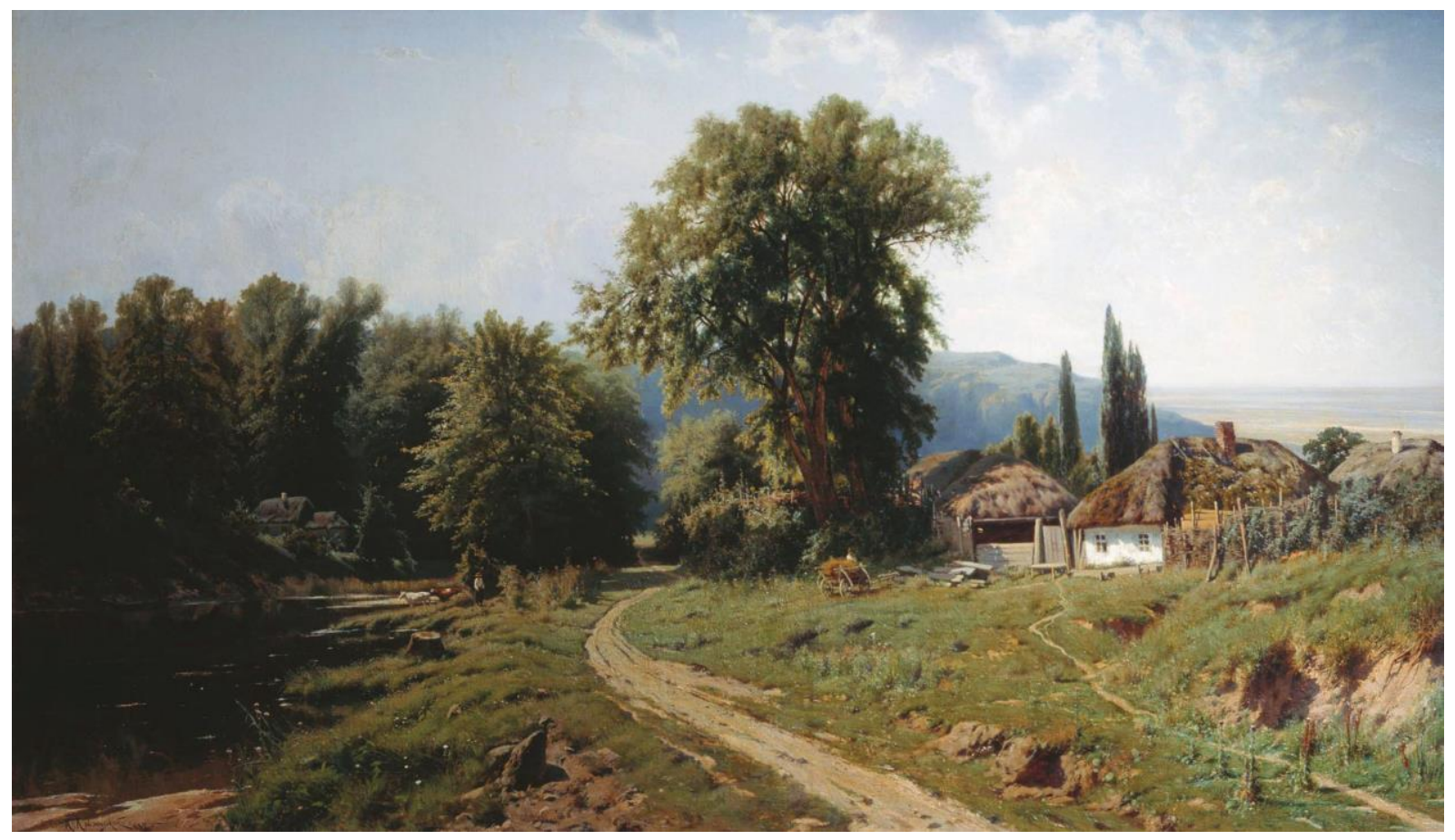

Kryjítskii, K. I. Uma granja na Maloróssia (1884) ${ }^{38}$

${ }^{38}$ Disponível em: <https://ru.wikipedia.org/wiki/\%CA\%F0\%FB\%E6\%E8\%F6\%EA\%E8\%E9,_\%CA\%EE\%ED\%F1\%F2\%E0\%ED $\% \mathrm{~F} 2 \% \mathrm{E} 8 \% \mathrm{ED} \% \mathrm{DF} \% \mathrm{EA} \% \mathrm{EE} \% \mathrm{E} 2 \% \mathrm{~EB} \% \mathrm{E} 5 \% \mathrm{E} 2 \% \mathrm{E} 8 \% \mathrm{~F} 7 \# /$ media/File:KonstantinKryzhitsky_HutorVMaloross ii_1884.jpg>. Acesso em: 17 mai. 2015. 
PARTE I 


\section{O romance gótico como um fenômeno literário}

O romance gótico inglês é um dos gêneros mais marcantes da prosa pré-romântica. Sua estética teve grande impacto na literatura mundial. Tendo surgido no final do século XVIII, o gênero inspirou numerosos autores tanto na Grã-Bretanha quanto fora - na França, na Alemanha e na Rússia. Começando como uma leitura popular para as mulheres, o romance gótico ganhou enorme sucesso no século XIX e permaneceu um gênero literário popular, mas controverso, durante toda a época do romantismo. Existem três variedades mais destacadas do gótico: o romance gótico inglês, o Schauerroman alemão e o roman noir francês. Da mistura desses três tipos, resultou a literatura fantástica do jovem romantismo alemão, no início do século XIX, posteriormente, muito influente na literatura russa e, particularmente, em Nikolai Gógol.

Segundo uma descrição que o estudioso Remo Ceserani dá ao romance gótico, entre as suas características principais estão

um gosto ambiguamente iluminado pelas manifestações do sobrenatural, dos fenômenos como o mesmerismo e a parapsicologia, das visitações e presenças dos espíritos e de fantasmas; uma atração fascinante pelo mistério da maldade humana, das perversões dos instintos e do caráter; uma preferência retórica pelo estilo e pelas ambientações elevadas e sublimes ${ }^{39}$.

Mas a peculiaridade principal do gótico consiste em uma mentalidade específica que questiona os valores morais tradicionais, o bem e o mal, as virtudes e os vícios humanos. $\mathrm{O}$ gótico submetia à prova as convicções filosóficas, religiosas e éticas do tempo, usando para isso situações extraordinárias, descomunais para os leitores. O insólito foi entrelaçado nas ocorrências obviamente "normais". Embora os autores góticos estivessem em oposição aos autores iluministas, sua ideia inicial, em sua essência, era bem iluminista: o mal não existe como uma parte da natureza humana, mas é formado pelas leis artificiais da moralidade e da ética.

\footnotetext{
${ }^{39}$ CESERANI, Remo. O fantástico. Trad. Nilton Cezar Tridapali. Curitiba: UFPR, 2006. p.89.
} 
Até hoje os pesquisadores da poética do gótico estão discutindo o que se pode incluir no assim chamado "cânone" do gênero. Alguns teóricos, como Ernest A. Baker ${ }^{40}$ e Mark Simpson ${ }^{41}$, supõem que o romance gótico, tendo seu florescimento no início do século XIX, após 1820 cedeu gradativamente seu espaço literário aos outros fenômenos da cultura. As fronteiras da poética do gótico, segundo esse conceito, devem ser, então, bem definidas: desde $O$ castelo de Otranto (The Castle of Otranto, 1764), de Horace Walpole, e até Melmoth ou o homem errante (Melmoth the Wanderer, 1820), de Charles Robert Maturin. Se seguirmos esse modo de raciocínio, deveremos analisar somente uma quantidade limitada dos romances dos autores britânicos: Horace Walpole, Matthew Gregory Lewis, Sophia Lee, William Beckford, Clara Reeve, Ann Radcliffe e Charles Maturin, entre alguns outros, excluindo seus seguidores e adaptadores de outros países.

O outro ponto de vista, mais popular entre os estudiosos ingleses e americanos - por exemplo, Devendra Varma ${ }^{42}$, Montague Summers ${ }^{43}$, George Haggerty ${ }^{44}$ - consiste em que o gótico inspirou o nascimento do romantismo, sobreviveu ao seu declínio e à existência do realismo, combinou com os descobrimentos do simbolismo e modernismo, mostrando sua continuidade literária durante quase três séculos. De acordo com o estudioso russo Vadim Vatsuro,

O romance gótico é um sistema íntegro e bem estruturado que foi gerado pela estética e filosofia pré-românticas; essa última predeterminou o caráter do conflito, a disposição das personagens, a hierarquia dos motivos e a soma dos procedimentos narrativos; ela criou também os modelos dos romances; sendo assimilados ou negados pela literatura subsequente, eles podiam ser desintegrados como uma formação íntegra, enriquecendo a tradição com seus elementos isolados ${ }^{45}$.

Até hoje esses elementos, ou, melhor dizer, traços da poética do gótico existem não só na literatura, mas na cultura popular: teatro, cinema e televisão, mostrando seus temas típicos como repressão, luta com a opressão, terror, uma tentativa de ultrapassar as limitações físicas e psicológicas de um indivíduo etc. Diz o estudioso americano Jerrold E. Hogle: “Agora não há dúvida de que o gótico, particularmente, na narrativa em prosa ou verso, teatro

\footnotetext{
${ }^{40}$ BAKER, Ernest. The history of the English novel. Vol. 5: The novel of sentiment and the Gothic romance. London: H.F. \& G. Witherby, 1942.

${ }^{41}$ SIMPSON, Mark S. The Russian Gothic novel and its British antecedents.Ohio: Slavic Publishers, 1986.

${ }^{42}$ VARMA, Devendra P. The Gothic Flame. London: The Scarecrow Press, 1987.

${ }^{43}$ SUMMERS, M. The Gothic Quest: A History of the Gothic Novel. New York: Russell \& Russell, 1964.

${ }^{44}$ HAGGERTY, George H. Gothic Fiction / Gothic Form. The Pennsylvania State University Press: University Park and London, 1989.

${ }^{45}$ VATSURO, V. E. Gotítcheski roman v Rossíi. Moskvá: Nóvoe literatúrnoe obozrénie, 2002. p. III.
} 
e filme - tudo que nós subentendemos na frase "ficção gótica" - tornou-se numa esfera duradoura e principal, embora amplamente variável, simbólica na cultura moderna e até pósmoderna ${ }^{46 "}$. A ideia de considerar como góticas as obras de um espectro histórico e poético bastante amplo parece-nos mais produtiva para uma tentativa de procurar uma semelhança tipológica entre essa tradição literária e as novelas de Gógol. Contudo é necessário delinear brevemente um quadro das obras dos seus supostos predecessores ingleses e discutir a novidade introduzida por eles na literatura europeia.

${ }^{46}$ HOGLE, Jerrold E. The Cambridge Companion to Gothic Fiction. New York: Cambridge University Press, 2002. p. 2. 


\section{O primeiro romance gótico: Horace Walpole e $O$ castelo de Otranto (1764)}

A vasta tradição crítica considera como o primeiro texto gótico $O$ castelo de Otranto, de Horace Walpole, que deu a sua obra o subtítulo "O conto Gótico" (The Gothic story). O romance de Walpole determinou o princípio do novo gênero que era uma combinação dos dois tipos de romance - o antigo romance de cavalaria, no qual tudo era "fantástico e inverossímil", com suas oportunidades para um jogo livre da fantasia, e o romance moderno, com sua reprodução fiel da natureza e dos heróis.

Em outras palavras, Walpole introduziu as ocorrências sobrenaturais no período histórico não muito distante do atual - na Idade Média. Porém o tempo histórico é convencional: as personagens de $O$ castelo de Otranto se comportam e conversam não como as pessoas do século XII, mas como os representantes do século XVIII. Tal "hibridismo" juntava a narrativa "medieval" e a "presente" numa mistura das fantasias sobrenaturais e da verossimilhança do tempo atual, dos caráteres convincentes e do seu comportamento autêntico e verdadeiro nas situações "extraordinárias". O elemento fantástico foi explicado pela difusão das crenças populares na Idade Média - um argumento histórico da Época do Iluminismo que foi também aplicado pelos autores russos no século $\mathrm{XIX}^{47}$. O terror como a "carta na manga" do autor chegou a ser um fundamento estético para o romance gótico posterior. O rico folclore britânico, especialmente os ghost stories, com suas bruxas e seus fantasmas, serviu como uma fonte de inspiração para as descrições dos fenômenos horríveis.

No seu prefácio para a segunda edição do livro, Walpole desenvolveu seu entendimento da autenticidade do caráter das personagens, baseando a sua estética em Shakespeare $^{48}$. Nas suas peças, os fantasmas apareciam para denunciar o crime escondido, assim como no gótico. Grande admirador dos métodos teatrais do dramaturgo britânico, Walpole também achava possível introduzir em sua obra tais fenômenos sobrenaturais. Não é uma coincidência que, nas obras góticas, o surgimento do elemento fantástico esteja ligado ao segredo não descoberto, como acontece nas tragédias Hamlet e Macbeth.

Entre os problemas que Walpole enfrentou, estava a mistura do estilo "alto" e "baixo" nas narrativas trágicas e dramáticas. As personagens de origem nobre não podiam

\footnotetext{
${ }^{47}$ O que não contarão as babas e o povinho estúpido!, exclama tipicamente uma das personagens de Noites em uma granja perto de Dikanka quando conta uma história sobre feitiçaria.

${ }^{48}$ WALPOLE, Horace. The Castle of Otranto, a Gothic Story. The third edition. London: Printed for John Murray, Successor to Mr. Sandby, №32, Fleet-street, 1769. p.xxiii. Disponível em: $<$ https://play.google.com/books/reader?printsec=frontcover\&output=reader\&id=QiAGAAAAQAAJ\&pg=GBS.P R3>. Acesso em: 13 mar. 2014.
} 
falar como camponeses, mas Walpole queria atingir o efeito do contraste entre os sofrimentos profundos dos heróis aristocratas e a comicidade e ingenuidade das personagens do povo. Portanto um dos componentes importantes da estética do gótico é a mistura da patética trágica com uma "palhaçada", tolice, ou truques engenhosos. Essa peculiaridade do gótico, junto com a potencial teatralidade, era também importante para Gógol nas suas novelas ucranianas.

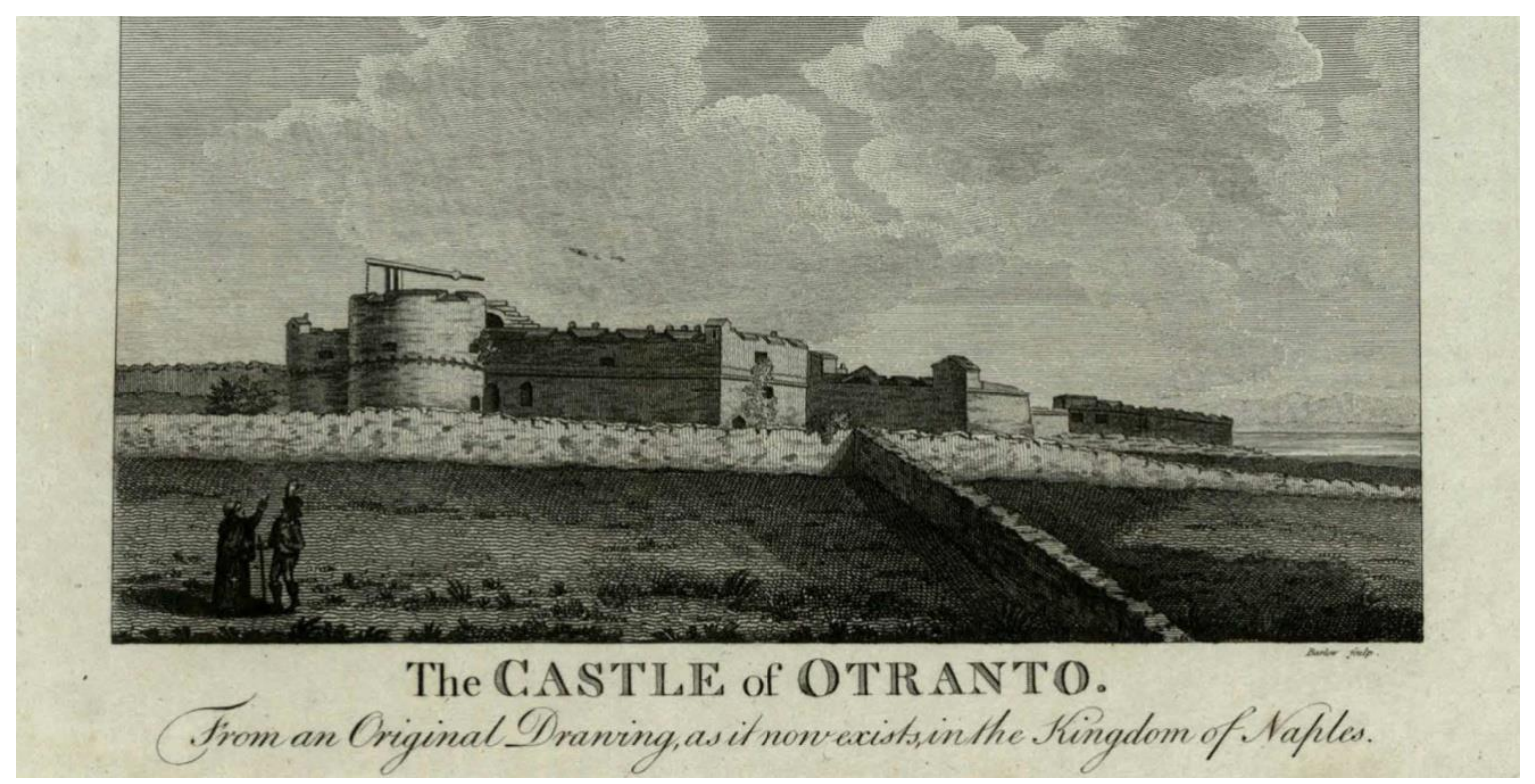

O castelo de Otranto. Uma gravura publicada em The works of Horacio Walpole, Earl of Oxford. In five volumes. London, printed for G. G. and J. Robinson and J. Edwards, 1798. 


\section{Outros autores góticos ingleses: Radcliffe, Lewis e Maturin}

Segundo Simpson, "a natureza humana é a feição central dos três romances góticos britânicos mais influentes: Os mistérios de Udolpho, de Ann Radcliffe; O Monge, de Matthew Gregory Lewis, e Melmoth ou o homem errante, de Charles Maturin ${ }^{49}$ ". Observando a dicotomia do bem e do mal sob novo ângulo, esses autores atingiram popularidade enorme, especialmente na Rússia. Eles compreenderam a obsessão com que os europeus apreciavam a liberdade, e disso surgiu, no gótico, uma luta constante contra as numerosas injustiças do mundo: contra o encarceramento, a atitude cruel do pai com sua filha, do marido com a mulher, a tirania da igreja e dos seus representantes, as dificuldades da vida feminina como o amor não correspondido, leis que impedem a união amorosa etc. Sem essa luta, o romance gótico não poderia existir.

Para a cultura russa, toda compreensão do romance gótico inglês estava relacionada ao nome de Radcliffe. Nos anos 1820, com o crescimento das tendências ligadas so irracional na literatura, os seus romances geraram novo interesse para com os fenômenos sobrenaturais, embora a posição iluminista da sua autora negasse a existência de espíritos e fantasmas. As discussões elevadas no final do século XVIII, no seu livro, Os mistérios de Udolpho (1794), sobre a possibilidade de manifestação das almas após a morte, surgiram com nova força na Rússia 30 anos mais tarde - nas novelas de Mikhail Zagóskin, Vladímir Odóevski e outros.

Os mistérios de Udolpho tornou-se muito renomado graças a vários fatores. Em primeiro lugar, era a descrição do vilão gótico Montoni. Apesar da sua crueldade, Montoni tinha profundidade do caráter e o humanismo - uma feição não típica para as personagens negativas da época, que não tinham nada de positivo na sua personalidade.

A segunda novidade que o romance introduziu foi a sensibilidade da heroína Emily St. Aubert, que criava premissas psicológicas e realistas para a motivação dos acontecimentos extraordinários. O leitor envolvia-se na ação do romance porque via tudo através das emoções da heroína, duvidando, muitas vezes, se algum fenômeno fantástico era realmente visto ou apenas imaginado por Emily.

O terceiro aspecto do romance da escritora é sua ênfase em paisagem. As descrições da natureza e dos edifícios são tão subsequentes na sua obra que os críticos nomearam seu estilo "uma arte pictórica"50". Uma pintora amadora na infância, Radcliffe aplicou seu

\footnotetext{
${ }^{49}$ SIMPSON, 1986, p. 13.

${ }^{50}$ Uma expressão de MILES, Robert, no seu artigo "Radcliffe, Ann” In KASTAN, David Scott (Org.) The Oxford Encyclopedia of British Literature. Oxford: Oxford University Press, 2005, tomo 4, p. 309.
} 
entendimento da arte às descrições da natureza, criando um padrão novo para seus seguidores. Por exemplo: "Ela viu somente imagens de grandeza sombria, ou de sublimidade espantosa, acerca de si; outras imagens, igualmente sombrias e igualmente terriveis, brilhavam na sua

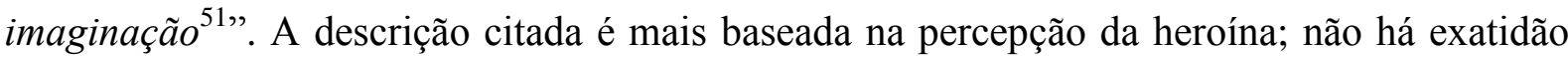
nos detalhes. O mesmo acontece nas descrições dos lugares, especialmente castelos, também vistos pelos olhos de Emily:

De lugares profundamente solitários nos quais ela estava emergindo, e do castelo sombrio, sobre qual ela tinha ouvido alguns avisos misteriosos, seu coração adoentado recuou em desespero, e ela percebeu que, apesar do que a sua mente já estava ocupada por aflição peculiar, ainda estava viva a influência de circunstâncias novas e locais; por que outro motivo ela estremeceria com a ideia deste castelo isolado?" ${ }^{, 52}$

Tais descrições subjetivas se tornaram padrão para o sentimentalismo russo do início do século XIX, por exemplo, nas obras de Nikolai Karamzin e Aleksandr Bestújev-Marlínski, os inspiradores e os fundadores do estilo gótico na literatura russa.

O Monge (1796), de Lewis, chocava o leitor já pelo tema escolhido: a queda moral do acólito que, pelo ímpeto de uma paixão proibida, assassinou sua mãe e se envolveu em um relacionamento incestuoso com sua irmã. A contribuição de $O$ Monge para a literatura era grande, por exemplo, ele inspirou $O$ Elixir do Diabo (Die Elixiere des Teufels, 1815), de E.T.A. Hoffmann ${ }^{53}$, cuja obra também é dedicada às aventuras e aos crimes do mongecapuchinho. O romance de Lewis trouxe para o gênero não apenas o sobrenatural, que já figurava prominentemente no gótico, mas o verdadeiramente satânico, o bizarro, o fantástico e o grotesco. Foi esse romance que polarizou a literatura gótica em duas tradições: a "terrível" (terrible) - sentimental, e a "horrível" (horrible) - negra.

Traduzido para o russo em 1802, o livro foi publicado com o nome de Ann Radcliffe na capa - um truque comercial para tentar vender mais exemplares. Essa edição estava presente nas várias bibliotecas particulares dos proprietários de terra russos, entre eles o

\footnotetext{
${ }^{51}$ RADCLIFFE, Ann. The Novels. Complete in one volume. New York: Georg Olms Verlag Hildesheim, 1974. pp. 245-246 (grifo nosso). ${ }_{53}$ Idem, Ibidem, grifo nosso.

53 A questão da relação entre a obra gogoliana e Hoffman é bem analisada, por exemplo, no artigo de IVANÍTSKI, Aleksandr, Gógol' $i$ Gofman: istok i preodolénie groteska. In MANN (org.), 2003, pp. 327-335. O pesquisador compara Gógol e Hoffmann em seu uso do grotesco como um procedimento artístico. Particularmente, ele observa que ambos os autores, desde sua obra jovem, misturavam os princípios vegetais, animalísticos e humanos nas suas metáforas.
} 
parente de Gógol, Dmitri Tróchtchinski ${ }^{54}$ e também o poeta e o amigo de Gógol, Vassíli Jukóvski $^{55}$.

Melmoth ou o homem errante (1820) de Maturin, extremamente popular na Rússia já nos anos 20 do século XIX (por exemplo, ele estava debaixo do travesseiro da heroína do romance em verso de Aleksandr Púchkin, Eugênio Onéguin), é o romance sobre um homem de origem nobre que vendeu sua alma ao diabo em troca da vida eterna, mas, por causa disso, ele é incapaz de conhecer o amor verdadeiro. Muitas potencialidades do gótico foram realizadas nesta obra: a profundidade da caracterização das personagens, o sobrenatural plausível, o herói simpático, mas mau, as paisagens exóticas e um interesse sincero por muitos aspectos contraditórios da natureza humana.

Segundo Simpson, Melmoth ou o homem errante, com sua imagem do vilão Melmoth - "um mal-entendido demônio arquetípico e patético ${ }^{56 "}$ - era um dos romances góticos mais importantes para a cultura russa. Ele observa os traços de sua influência na novela A Dama de Espadas, de Aleksandr Púchkin, e no poema de Mikhail Lérmontov, O Demônio. O estudioso do romance M. Alekséev explica que o sucesso do romance na sociedade russa estava relacionado ao significado filosófico profundo da obra em questão, mostrado através das imagens inesperadas e formas fantásticas ${ }^{57}$. Melmoth venceu os leitores com sua negação romântica da realidade, a sua ideia do domínio fatal do mal nas esferas diferentes da vida social do mundo contemporâneo, na força da acusação apaixonada do escritor. O nome de Melmoth, em muitas literaturas, inclusive russa, tornou-se um termo comum para dar uma característica a uma personagem decepcionada, que critica ferozmente todas as tradições, as normas éticas, os numerosos vícios dos humanos independentemente do lugar onde eles moram e do tempo em que vivem.

\footnotetext{
${ }^{54}$ Consideramos o catálogo da biblioteca de Dmitri Tróstchinski um importante documento histórico. De acordo com a lista dos livros que ele possuía, podemos chegar à conclusão de que ele era um grande colecionador de romances góticos, não só dos livros de Radcliffe e Lewis, mas também de todas suas imitações. Nela estava $O$ sino de meia-noite (The Midnight Bell, 1798), de Francis Lathom, O Romance de Pirineus (Romance of the Pyrenees, 1803), de Catherine Cuthbertson, e livros de outros autores próximos ao gênero gótico, como Anna Maria McKenzie, John Moore, Christian Heinrich Spiess, François Guillaume Ducray-Duminil - Cf. TCHUDAKOV, G.I., Otnochénie tvórtchestva N.V. Gógolia k zapadnoevropéiskim literaturam. Kiev: 1908. Como há muitas testemunhas de que na infância Gógol passou bastante tempo na casa de Tróstchinskii e emprestava seus livros (Ver, por exemplo, VERESSÁEV, 1933, ZOLOTÚSSKI, 2005), consideramos extremamente plausível que Gógol tivesse conhecimento sobre esses autores góticos.

55 LOBÁNOV, V.V. (Org.). Biblioteka Jukóvskovo: opissánie. Tomsk: Izdátel'stvo Tómskogo universiteta, 1981. p. 38, ítem № 200.

${ }^{56}$ SIMPSON, 1986, p. 74.

57 ALEKSÉEV, M. P. Tch. P. Mét'iurin i evo “Mel'mot skitálets”.Moskvá: Naúka, 1983. Disponível em: <http://thelib.ru/books/alekseev_m/chrmetyurin_i_ego_melmot_skitalec-read.html>. Acesso em: 20 jun. 2015.
} 


\section{O impacto do gótico na cultura}

Apesar de suas diferenças, os escritores góticos ingleses estabeleceram um conjunto de procedimentos que poderiam variar de um romance para outro, mas em sua essência formavam um padrão para o gênero. Um dos primeiros estudos detalhados do gótico como um fenômeno cultural foi feito pelo escritor Walter Scott. Em 1824, publicou um breve artigo póstumo dedicado a Ann Radcliffe, sob o nome Biografia preliminar aos romances de Mrs Ann Radcliffe (Prefatory Memoir to the Novels of Mrs Ann Radcliffe) ${ }^{58}$, que dois anos depois foi traduzido e publicado na revista russa Filho da pátria (Syn Otétchestva). As feições góticas que Scott destaca até hoje podem servir como uma síntese precisa dos seus procedimentos:

- Os romances góticos possuem o efeito profundo e poderoso de provocar medo nos seus leitores, seja ele produzido pelos perigos naturais ou pelas sugestões de superstição.

- É comum o uso da imaginação, aventuras seguidas de aventuras, com muitas fugas, capturas e perseguições que desviam o enredo e prorrogam o tempo da ação.

- A obra mostra personagens típicas. As pessoas são retratadas não com as feições individuais, mas com as características da classe a qual elas pertencem: "Um conde sombrio e tirânico; uma velha governanta, um contador de lendas familiares; uma empregada doméstica tagarela; um criado alegre e despreocupado; um ou dois vilões na obra; e uma heroína, cheia de perfeições e sujeita a qualquer espécie de perigo ${ }^{59,}$.

- Presença obrigatória do exótico, característico para a Europa medieval: a inquisição onipotente, os castelos com masmorras e os terrores de torturas para criar um ambiente de opressão e para ter uma justificação do elemento fantástico.

- Suspense e mistério como componentes da obra, porque "existem poucos perigos que não se familiarizam a uma mente firme se eles são apresentados à consideração como certezas, $[\ldots]$ enquanto, por outro lado, os mais corajosos se esquivavam do escuro e duvidoso ${ }^{60}$,

\footnotetext{
58 SCOTT, Walter. Prefatory Memoir to Mrs. Ann Radcliffe. In London: Hurst, Robinson and Co. 1824.

${ }^{59}$ Idem, Ibidem, p. xviii.

${ }^{60}$ Idem, Ibidem.
} The novels of Mrs. Ann Radcliffe. 
- Todas as circunstâncias da narrativa, não importam o quão misteriosas ou, aparentemente, sobre-humanas, podem ser explicadas; pertencem aos princípios naturais no final.

- A paisagem na obra é indefinida e deixa muito à imaginação dos leitores: em vez de descrições concretas da natureza, o autor aplica os adjetivos abstratos, como sublime, majestoso, grandioso, apavorante etc.

- Introdução da narrativa poética na prosa (trechos de verso dentro do romance ou descrições poéticas).

O romance gótico surpreendeu os leitores com uma vitimização incessante das pessoas inocentes. Os vilões eram obcecados pelo poder, luxúria, dinheiro. Essa luta das personagens levantava um sistema de oposições: o gótico mostrava um confronto entre a vida e a morte, o natural e o sobrenatural, o antigo e o moderno, o justo e o injusto, o inconsciente e o consciente. Segundo o estudioso Fisher, o arsenal de ferramentas que na mente do leitor comum é ligado ao gótico como castelos, fantasmas e sepulturas seguia um objetivo sério: com as cenas chocantes levantar "questões de identidade e poder, frequentemente ligadas às situações familiares [...] que ao lado da sexualidade e considerações do gênero, chegaram a ter mais importância que os cenários lúgubres que forneciam fundos misteriosos para discursos igualmente misteriosos e ações nos trabalhos góticos anteriores ${ }^{61 "}$.

Uma das contribuições do gótico mais importante para a cultura mundial e, especialmente, para a cultura russa é o tema da luta do homem contra seus limites - materiais, psicológicos, sociais, religiosos etc. Esse tema é a base para muitos enredos góticos. Em O castelo de Otranto, por exemplo, a heroína Isabella tenta escapar do vilão Manfred que quer casar com ela contra sua vontade. Para fugir ao casamento, ela precisa passar por várias aventuras, entre as quais - a longa jornada nos numerosos corredores do castelo de Otranto. Seu caminho para a liberdade física corresponde, na obra, à sua libertação psicológica e social - no final ela casa com o homem que ama de verdade, um simples camponês. O mesmo acontece com a heroína de Os mistérios de Udolpho, Emily St. Aubert, uma jovem órfã, que é forçada a morar com sua tia, Madame Cheron. O marido de Madame Cheron, Montoni, leva Emily e a sua esposa no seu remoto castelo de Udolpho. Muitos testes terríveis e misteriosos esperam Emily quando ela tenta escapar do castelo; porém ela consegue se livrar e casar com o homem pobre que a ama.

\footnotetext{
${ }^{61}$ FISHER, Benjamin Franklin. Poe and the gothic tradition. In HAYES, Kevin The Cambridge companion to Edgar Allan Poe. Cambdridge: Cambridge University Press, 2002. p. 74.
} 
O tema da luta contra os limites da religião é mostrada em $O$ Monge. Nesse romance, o monge Ambrósio sucumbe às várias tentações proibidas: quebra o juramento de celibato; usa magia negra; comete, sem saber, o incesto com sua irmã e mata sua mãe. Ao mesmo tempo, uma das freiras do outro monastério é condenada a uma morte horrível, por envenenamento, pelo crime de se apaixonar por um homem e engravidar. A ideia do romance é o carater artificial de algumas restrições religiosas, que pode levar as pessoas a crimes muito mais horríveis.

A luta contra as limitações também é um dos temas principais em Noites em uma granja, de Gógol. Seus heróis constantemente tentam, embora nem sempre com sucesso, ultrapassar várias fronteiras para atingir sua felicidade. O cossaco Danilo, em A Terrível Vingança, recusa obedecer às leis seculares do clã para defender sua esposa. Petró, de $A$ noite da véspera do dia de Ivan Kupala, vende sua alma ao diabo para conseguir o ouro que ele necessita para se casar com sua namorada. Levkó, de Uma noite de maio, e o cossaco de A Carta Perdida empreendem uma viagem perigosa ao mundo do além para procurar os objetos perdidos.

A sensibilidade das heroínas, provavelmente, entrou "na moda" com o gótico. Os primeiros índices do psicologismo foram realizados numa heroína de novo tipo - não só uma donzela em perigo, mas uma pessoa sensível e inteligente. Tatiana Lárina, em Eugênio Oneguin, de Púchkin, no seu modo de pensar e refletir sobre as situações dramáticas, copia rigorosamente as heroínas dos romances sentimentais de Radcliffe. Em Gógol, Katerina, de $A$ Terrivel Vingança, Pidorka, de A Noite de véspera do dia de Ivan Kupala, Ganna e Pánnotchka de Uma noite de maio - todas são extremamente sensíveis, elas preveem os desastres que podem acontecer com elas e com seus próximos.

As preocupações, os pressentimentos de algo terrível, especialmente nos caráteres femininos, tornaram-se populares com a imagem de Emily St. Aubert, de Os mistérios de Udolpho. Essa jovem aprecia profundamente a beleza da natureza, é apaixonada por livros, poesia e música. Radcliffe a descreve como extremamente virtuosa, obediente, mas ao mesmo tempo engenhosa, corajosa e independente. A personagem aprofunda a visão do leitor do romance com sua versão subjetiva dos acontecimentos e deixa dúvidas sobre a sua natureza. Segundo Baker, o desenvolvimento extremo da sensibilidade das heroínas, e particularmente sua suscetibilidade aguda às emoções de terror e temor, são dominantes na poética do gênero ${ }^{62}$.

\footnotetext{
${ }^{62}$ BAKER, 1942, p. 193.
} 
Entrando em polêmica com o Iluminismo, o gótico propôs uma revisão das questões morais e éticas. A quintessência dessa revisão é mostrada por meio da imagem contraditória do vilão gótico. O feiticeiro de Gógol, em $A$ Terrível Vingança, sem dúvida, não poderia existir sem a descrição brilhante de Melmoth. O romance gótico foi um dos primeiros a transformar a visão do vilão na obra: antes ele era unívoco, sem feições atraentes; até a sua aparência, via de regra, era repugnante. O vilão gótico é diferente, ele desafia os valores falsos da sociedade, visto não somente como um criminoso, mas também como uma vítima. Perturbador e demoníaco, o vilão possui um charme encantador e ambivalente de um rebelde, um desafiador das restrições dos costumes sociais. O mal verdadeiro é visto em manifestações de tirania, corrupção e hipocrisia, em pessoas ou instituições de poder, em hierarquias governamentais, normas sociais e superstições religiosas. Enganosa, desumana e má, a sociedade não deixa ao vilão uma alternativa no seu caminho ${ }^{63}$. Melmoth parece menos cruel que a Inquisição, que condena as pessoas inocentes. Incapaz de sentir o amor, ele suscita mais simpatia no leitor do que aqueles que o condenam.

Tendo surgido em uma época de várias transições politicas, econômicas e culturais, o romance gótico suscitou uma onda de interesse pela história, e não por coincidência. $\mathrm{O}$ tempo das revoluções é anti-histórico por sua natureza, o tempo das reformas sempre faz as pessoas refletir sobre os caminhos de história ${ }^{64}$. Disso surge, nos romances, uma correlação entre acontecimentos do passado e da modernidade e os temas relacionados com o tempo histórico. O tempo no gótico não é linear: os acontecimentos do passado possuem influência mágica sobre o presente. O crime escondido "tenta" ser desvelado através das aparições dos fantasmas, da leitura dos manuscritos antigos, da compra dos retratos dos parentes que parecem ser os duplos idênticos dos heróis, e das revelações tardias dos criados. É introduzido o tema da maldição familiar, que também conecta os eventos do passado com o presente. A estrutura da narrativa mostra o desenrolar dos acontecimentos de um modo retrospectivo, em primeiro lugar, mostrando um fenômeno e só depois explicando-o. Tal atitude em relação ao tempo é característica em Noites: em três das quatro novelas aqui analisadas, os eventos do passado distante ou próximo definem a imagem do presente. Uma novela mais curiosa nesse sentido é, provavelmente, A Terrivel Vingança, com sua estrutura temporal complexa. O texto é dividido em três níveis temporais: o presente, o passado próximo e o tempo pré-histórico, mostrados ao leitor através dos narradores.

\footnotetext{
${ }^{63}$ BOTTING,Fred. Gothic. London: Routledge, 1996. p. 98.

${ }^{64}$ LÓTMAN, Iúri. Bessedy o rússkoi kul'ture. Sankt-Peterburg: Ázbuka, 2014. p. 15.
} 
A paisagem começa a ser um "catalisador" da atmosfera sinistra do romance gótico. Os fenômenos fantásticos (ou, no gótico sentimental, os fenômenos que o próprio herói percebe como fantásticos), na obra, combinam com a contemplação da natureza, que, no herói sensível, provoca emoções de enlevo e sublime. Isto é, especialmente, visível nos romances de Ann Radcliffe, porque, antes dela, ninguém usava o ambiente como elemento principal do enredo. Mesmo nas situações desastrosas, suas heroínas não deixam de sentir conforto espiritual quando contemplam florestas, lagos, mares, montanhas. Isso é um resultado natural da sua sensibilidade, que também combina bem com os sentimentos de suspense ${ }^{65}$.

Em Gógol, a paisagem e o espaço, em geral, cumprem um papel importante: usando o procedimento que nós chamamos de "ativação do gótico", o autor coloca os objetos e os fenômenos mágicos dentro de um ambiente cotidiano. Uma descrição de um elemento provocador, como, por exemplo, o castelo, em A Terrível Vingança; um barranco, em A noite da véspera do dia de Ivan Kupala; uma casa abandonada, em Uma noite de maio e um bosque, em A Carta Perdida, dão ao autor uma oportunidade de deslocar a ação para o mundo diferente. A análise rigorosa do espaço em Noites encontra-se no Capítulo III da presente dissertação: Elementos da poética do gótico em Noites em uma granja perto de Dikanka de Nikolai Gógol.

${ }^{65}$ BOTTING, 1996, p. 194. 


\title{
II.
}

\section{Recepção do gótico na Rússia}

\author{
Da musa inglesa, a fantasia \\ Da jovem o sono interrompia, \\ E ora seu ídolo adotivo \\ Fez-se o Vampiro pensativo, \\ Ou o Melmoth, um ocioso, \\ Ou o Corsário, o Hebreu Errante, \\ Também Sbogar, vago, distante ${ }^{66}$. \\ (Aleksandr Púchkin. "Eugênio \\ Oneguin", capitulo III, estrofe XII, \\ 1833).
}

A questão da refração da tradição gótica inglesa na literatura russa é, em primeiro lugar, uma questão de correspondência entre as duas culturas, de adaptação de algumas ideias inglesas no panorama eslavo. A primeira onda de interesse pelo romance gótico na Rússia, mais conhecido na época como "o romance dos terrores e mistérios", "o romance em tom horrorizante" ou "em estilo inglês", ocorreu no final do século XVIII e no início do século XIX. A princípio, os textos dos autores britânicos chegaram a ser conhecidos na Rússia indiretamente - por meio de traduções, adaptações, imitações e até plágios franceses e alemães. Mesmo assim, como veremos, ficaram incorporados nos fundamentos da cultura do país.

Simpson supõe que uma provável razão da popularidade do gótico na Rússia fosse sua natureza iconoclasta: "A norma gótica prevalecente é sempre uma luta contra aprisionamento e prejuízo social. A literatura gótica é antiautoritária e invariavelmente lida com as vítimas do despotismo e tirania - religiosa, social, política e familiar ${ }^{67 \%}$. O que interessou o leitor russo foi essa tentantiva de libertação. Tal estado de espírito coincidiu com o ambiente histórico da época: na alta sociedade russa da primeira metade do século XIX, particularmente, após a revolta dos Dezembristas, em 1825, havia um sentimento coletivo de pavor pelas repressões que a seguiram. Tais repressões afetaram um grande círculo de

\footnotetext{
${ }^{66}$ PUSHKIN, Aleksandr. Eugênio Oneguin. Romance em versos. Moscou: Grupo Editorial "Azbooka - Atticus", 2008. p. 137.

${ }^{67}$ SIMPSON, 1986, p. 19.
} 
pessoas. Os terrores na vida combinavam com as descrições dos horrores nos romances góticos, a literatura se desdobrava na cultura e vice-versa.

Outras razões para a popularidade do romance gótico eram seu apego a Shakespeare, que gerava grande interesse entre os russos, desde meados do século XVIII, e uma conexão profunda do gótico com o folclore e a mitologia, conforme salientamos anteriormente. A associação do gótico com o conto maravilhoso pode não parecer tão evidente, mas as personagens dos romances, na mente de muitos leitores, se mesclavam aos heróis e aos vilãos dos contos populares eslavos. O romance e o conto não contradiziam um ao outro ${ }^{68}$. A tradição do gótico, na sua essência, era baseada nas lendas, sagas, contos maravilhosos. Os críticos russos sentiam essa ligação desde os primeiros romances góticos traduzidos. $\mathrm{O}$ autor desconhecido de A Revista Moscovita (Moskovski Jurnal) escreveu (na sua resenha №7, junho, 1792), que, nos textos góticos, o esplendor dos assuntos folclóricos e mitológicos consistia, em sua posição, "acima e além de todos os nossos conceitos de moralidade ${ }^{69 "}$.

Provavelmente, a primeira obra gótica que atingiu o público russo foi $O$ castelo de Otranto. O público russo conheceu o romance na tradução francesa que foi publicada em 1767. Mais tarde, nos anos 1790, Ann Radcliffe atingiu sucesso na Rússia, o que coincidiu com o florescimento do sentimentalismo no país. Seus romances foram lidos logo que saíram as traduções para o francês. Lev Tolstói, em um dos seus rascunhos para o romance Guerra e $P a z$, descreveu uma situação cultural dos primeiros anos do reinado de Alexandre I: "Nossas mães $[\ldots]$ admiravam os romances da madame Radcliffe ${ }^{70,}$.

Um dos primeiros admiradores de Radcliffe na literatura russa foi o escritor Piótr Chálikov (1768-1852). Em Os mistérios de Udolpho, Chálikov via, em primeiro lugar, a estética do "terror doce". Esse conceito, divulgado no fim do século XVIII, baseava-se nas ideias do livro Um inquérito filosófico dentro da origem de nossas ideias sobre o Sublime e Lindo (A Philosophical Enquiry into the Origin of Our Ideas of the Sublime and Beautiful, 1757), do filósofo inglês, Edmund Burke. De acordo com sua estética, o sublime era uma necessidade mental e fisiológica da alma humana ${ }^{71}$. Segundo Burke, existem duas variedades de sublime: o "terror" e o "horror". O pesquisador Devendra Varma explica a diferença entre elas: o terror provoca a intangível atmosfera de pavor psíquico e espiritual, certo

\footnotetext{
${ }^{68}$ Iúri Lótman diz que os romances, no começo do século XIX, influenciavam muito na formação das pessoas; eles tinham impacto nunca visto antes ou depois. LÓTMAN, 2014, pp. 81-82.

${ }^{69}$ SIMPSON, 1986, p. 282.

${ }^{70}$ TOLSTÓI, L. N. Pólnoe sobránie sotchinéni v 90 tomakh. Moskvá: Gosudárstvennoe izdátel'stvo khudójestvennoi literatury, 1928-1958. Tomo 13. p. 75.

${ }^{71}$ CLERY, E.J. The genesis of “Gothic” fiction. In HOGLE (Org.), 2002, p. 35.
} 
estremecimento supersticioso com o outro mundo. O horror expõe uma imagem mais crua do macabro por uma representação exata do fisicamente horrível e revoltante ${ }^{72}$. Na ideia de Burke, "o terror estimula a imaginação enquanto o horror paraliza a alma ${ }^{73}$ ". O terror mantém as personagens e os leitores em estado de ansiedade devido às ameaças (à vida, à segurança e à saúde mental) que, normalmente, não são vistas ou são representadas pelas sombras do passado desconhecido. Radcliffe e seus seguidores, mais conhecidos como os autores do "gótico sentimental", provocaram exatamente esse sentimento. O horror mostra o confronto dos protagonistas com a bruta violência física ou psíquica, destruindo explicitamente as normas assumidas pela sociedade ${ }^{74}$, variedade do gótico que é mais associada ao nome de Matthew Gregory Lewis.

Na Rússia, a partir dos anos 1800, a popularidade de Radcliffe era tão grande que gerou um sem-número de livros e contos com seu nome fraudulentamente colocado para aumentar as vendas. Curiosamente, essa "pseudo-Radcliffe" criava uma imagem específica da escritora: o estilo sentimental, típico para a autora, era unido com a poética do horror gótico, com suas descrições aterrorizantes e chocantes. Assim, o terror e o horror, essas duas tendências estéticas muito diferentes, se juntavam na recepção do leitor russo.

Os anos 1800 assinalam também o crescimento do interesse dos leitores russos por outros autores góticos, entre eles, Clara Reeve, Sophia Lee e William Beckford. As traduções indiretas dos seus textos, muitas vezes feitas pelos autores anônimos do francês, foram ainda retrabalhadas artisticamente. Trechos inteiros eram alterados e alguns episódios ou diálogos, removidos. Podem-se considerar essas adaptações uma primeira tentativa de transferência parcial do romance gótico para o sistema cultural da prosa iluminista russa.

$\mathrm{Na}$ opinião da estudiosa Ekaterina Samoródnitskaia, a recepção russa da abundante produção literária gótica enfatizava os dois princípios que formavam sua poética - o terror e o mistério, enquanto os "acessórios cênicos", como um meio de atingir o efeito necessário, tomavam o segundo lugar ${ }^{75}$. Esses acessórios, ao contrário, foram criticados. O famoso jornalista da época, Orest Sómov, parodiando os romances góticos, até publicou uma "receita" cômica para escrever um bom romance de terror:

\footnotetext{
${ }^{72}$ VARMA, 1987, p. 98

${ }^{73}$ SUMMERS M. The Gothic Quest: A History of the Gothic Novel. New York: Russell \& Russell 1964. apud VATSURO, 2002, p. 107.

${ }^{74}$ HOGLE (Org.), 2002, p. 3.

75 SAMORÓDNITSKAIA, Ekaterina. "Británskoi muzy nebylitsy”: ob otnochénii Gógolia $k$ gotítcheskim romanam.In MANN (org.), 2003. pp. 305-311.
} 
Tenha um castelo antigo em ruínas, coloque-o onde quiser, tanto faz, o lugar só deve ser bruto, o ar insalubre e nebuloso. O castelo deve ser inabitado. [...] Acrescente a isso subterrâneos húmidos e sombrios, nos quais se entram através de portas deslizantes e nos quais deve haver uma grande quantidade de masmorras, as mais terríveis que se pode imaginar. [...] Quando dispuser os lugares e assim abastecer-se, você terá tudo necessário para seu romance ${ }^{76}$.

Nos anos 1810, os críticos russos começaram a compreender o gótico como uma mistura de meios literários já estabelecidos, “juntados” mecanicamente. A ampla divulgação de imitações de clássicos góticos deslocava esse gênero da literatura alta para a literatura de massa. A mera menção do nome de Radcliffe era significativa: a devoção às suas obras era alvo de piadas, ou, até mesmo, considerada um indício de nível cultural e social provinciano.

Parece representativa a resenha do crítico anônimo na revista O Filho da Pátria (Syn Otétchestva), na qual o seu autor desconhecido fala sobre uma tradução de um dos Schauerroman do autor alemão, Christian August Vulpius. Para esse crítico, o romance gótico é um produto literário de baixa qualidade: "Não, prezados senhores, apesar do afinco de atividade da polícia literária, bandoleiros, mortos, diabos ainda estão aninhados nos castelos, nas ruínas, cavernas e florestas, assustam os transeuntes, arrancam seu dinheiro e o carregam - para as livrarias ${ }^{77,}$.

A primeira vista, desde os anos 1820, o romance gótico, já era um fenômeno arcaico para a literatura russa. Mas essa opinião não é completamente correta. Durante os anos 18201830, as revistas continuaram publicando muitas traduções, imitações e obras originais próximas ao romance gótico. Entre os autores que contribuíram para essa tradição, estão Nikolai Karamzin, Aleksandr Bestújev-Marlinski, Vassíli Jukóvski, Aleksandr Izmáilov, Vassíli Naréjnyi, Nikolai Gnéditch, Evgéni Baratynski, Mikhail Zagóskin e até Aleksandr Púchkin. Simpson afirma que, na Rússia, a influência gótica britânica era duradoura e os autores a seguiram com incrível fidelidade ${ }^{78}$.

\footnotetext{
${ }^{76}$ Syn Otétchestva (1816) apud VATSURO, 2002. pp. 339-340.

${ }^{77}$ Idem, Ibidem.

${ }^{78}$ SIMPSON, 1986, p. 19.
} 


\section{Alguns romances góticos russos}

\section{A Ilha Bornholm, de Nikolai Karamzin (1794)}

Desde os anos 1790, pode-se já falar não só em consumo passivo do gótico na

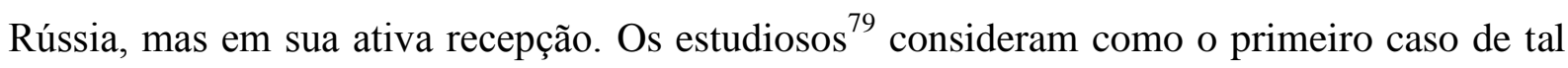
domínio do estilo gótico a novela de Nikolai Karamzin A Ilha Bornholm (Óstrov Borngol'm). Gógol, sem dúvida, conhecia essa obra. O autor, em uma viagem, em 1829, observou a ilha na Noruega que inspirou Karamzin e escreveu em uma carta a sua mãe: "A vista da ilha Bornholm, com suas rochas selvagens e descobertas e, ao mesmo tempo, com a verdura florescente dos vales e as casinhas bonitas, é maravilhosa ${ }^{80 "}$.

Publicada em 1794, a novela de Karamzin ainda não é independente dos seus predecessores da Inglaterra. Assim como Walpole, no seu romance, descrevia os eventos misteriosos na Itália medieval, um espaço exótico para os leitores britânicos, Karamzin também coloca a ação fora do seu país nativo - em o caso de A Ilha Bornholm, destaca a Noruega. Essa ilha realmente existe no mar Báltico, no território da atual Dinamarca. O castelo Hammershus, mencionado na novela, existia desde a Idade Média. Como está descrito na obra, os barcos realmente paravam com frequência numa das baías da ilha à noite.

Os temas usados em A Ilha Bornholm também são próximos à poética do gênero particularmente o tema do incesto, difundido nos romances ingleses ${ }^{81}$. Para os autores góticos, o incesto chegou a ser um instrumento útil para confrontar o problema ético das pessoas bondosas e jovens que cometem um pecado mortal, às vezes, contra sua vontade ou por falta do conhecimento de todas as circunstâncias. Na sua novela, Karamzin conta uma triste história do amor incestuoso entre o jovem irmão e sua irmã que são punidos cruelmente por seu pai.

Karamzin introduziu os trechos poéticos dentro do texto prosaico - uma pecularidade característica dos romances sentimentais de Ann Radcliffe. O estado de espírito do narrador é definido pela canção que ele ouve do seu amigo: “As leis condenam o objeto do meu amor". Esse poema, em um contexto paródico, aparece, em 1841, no texto da comédia

\footnotetext{
${ }^{79}$ SIMPSON, 1986; VATSURO, 2002.

80 GÓGOL, N.V. Pólnoe sobránie sotchinénii v 14 tomakh. Tomo 10. Cartas, 1820-1835. In MECHTCHERIAKOV N. K. (org.). Moskvá-Leningrad: AN SSSR, 1940. p. 161.

${ }^{81}$ A estudiosa Ann Tracy fez uma pesquisa detalhada dos romances góticos e descobriu que, no período entre os anos 1790 e 1830, pelo menos, 53 romances, dos mais divulgados, tratavam do tema do incesto. In TRACY, Ann B. The Gothic Novel, 1790-1830. Lexington: University of Kentucky, 1981.
} 
gogoliana $O$ inspetor geral - fato que mostra uma ampla divulgação da novela de Karamzin na Rússia, porque até uma pessoa inculta, como o protagonista da comédia, a conhece.

O espaço exótico, o tema do incesto e o uso da poesia dentro da prosa indicam a influência dos romances de terror na obra de Karamzin. Contudo, A Ilha Bornholm era uma obra original. $\mathrm{O}$ escritor russo não repetiu o estilo gótico por completo. Para os romances "com o espírito de Ann Radcliffe", era característica a complexidade do enredo e da composição da frase. Não conseguindo chocar o leitor a cada instante, tais romances eram sobrecarregados de detalhes. Karamzin, pelo contrário, tentou ser breve e exato. Simpson menciona três elementos do estilo de Karamzin: brevidade, estudo atento dos sentimentos humanos e uma simplificação geral da língua literária ${ }^{82}$. Ele recusou o uso dos estilos "alto" e "baixo", tentando formar uma linguagem mais homogênea, mais próxima da fala popular.

Com sua novela, Karamzin deu um forte impulso ao nascimento de mais uma "onda do gótico" na Rússia. Dos seus textos pré-românticos, surgiram muitas imitações. Karamzin foi o primeiro autor russo a introduzir uma paisagem "psicológica" na obra, isto é, a descrição da natureza que evocava emoções de melancolia em leitores, os fazia pensar na brevidade da vida e na proximidade da morte. As descrições de natureza em Noites, de Gógol, carregam os traços vagos da tradição karamziniana: a paisagem sombria e sinistra prepara o leitor para os acontecimentos descomunais e possivelmente perigosos. Por exemplo, a descrição do lago, em Uma noite de maio, dá ao autor a oportunidade de introduzir o elemento mágico no enredo: observando o lago e a casa, os leitores, junto com a heroína, imediatamente, querem saber o que acontecera nesse lugar no passado:

[...] o lago sombrio, cercado por uma floresta escura de bordo e pelos salgueiros chorosos, que afogaram nele seus galhos lamentosos. Como um fraco ancião, ele agarra com seus abraços frios o céu longínquo, escuro, cobrindo de beijos gélidos as estrelas ardentes que, opacas, deslizam no meio do morno ar noturno, como se estivessem pressentindo o surgimento próximo do esplêndido rei da noite. Ao lado do bosque, num morro, cochilava uma velha casa de madeira com contraventos fechados; o musgo e a erva daninha cobriam seu telhado; macieiras frondosas haviam crescido em abundância diante de suas janelas; o bosque, envolvendo-a com sua

${ }^{82}$ SIMPSON, 1986, p. 30. 
sombra, conferia-lhe um aspecto soturno e selvagem; um nogueiral estendia-se junto a sopé dele e descia ao lago ${ }^{83}$.

${ }^{83}$ GÓGOL, 1976, tomo I, p. 57. 


\section{O Couraceiro de Aleksandr Bestújev-Marlínski (1832)}

Aleksandr Bestújev-Marlínski por muito tempo foi um dos poucos autores russos cujas conexões com o romance gótico - verdadeiras ou fictícias - foram discutidas em numerosos trabalhos científicos. Participante da Revolta dos Dezembristas - situação que afetou consideravelmente a escolha dos enredos nos seus romances, cheios de aventuras e desenlaces inesperados - Marlínski não só era grande admirador das obras de Ann Radcliffe, mas também seu agudo estudioso. Ele lia com atenção a crítica do tempo sobre o gótico, inclusive os artigos de Walter Scott, e tentou aplicar algumas leis da sua poética nas suas obras, como, por exemplo, introduzindo um espaço exótico no enredo, empregando suspense e mistério como componentes importantes da ação, descrevendo uma paisagem "sugestiva" etc. Seu $O$ Couraceiro (Látnik) pode ser considerado um romance que explora, de um modo mais distinto e detalhado, a tradição do gótico na Rússia.

O enredo de $O$ Couraceiro é baseado, parcialmente, no folclore e na história russos. Marlínski era o primeiro autor que transportou o lugar dos acontecimentos da Europa medieval para a Rússia quase contemporânea (do final do século XVIII). Ele provou que, para o romance gótico, o ambiente medieval não é necessário. Assim como Charles Maturin acreditou que a sua sociedade nativa irlandesa poderia servir como uma fonte de inspiração para um bom romance de terror, Bestújev também acreditou que a realidade russa poderia fornecer uma atmosfera gótica crível. Ele notou que as bruxas, as sereias e os monstros das florestas escuras dos contos maravilhosos russos poderiam ser usadas como os personagens num ambiente gótico.

O escritor retrabalhou uma velha lenda russa sobre o castelo de Churán, na margem do rio Kama (Rússia Central). No século XVIII, nesse castelo, morava um proprietário de terras Narmátski, famoso por suas crueldades com os servos e os membros da sua família. O escritor aprofundou a imagem de um tirano doméstico. $\mathrm{O}$ seu herói não é somente possuído pelas paixões proibidas, mas também tem personalidade profunda e complexa. Uma paixão amorosa combina nele com um sofrimento titânico, hiperbólico, mais característicos para o herói romântico byroniano.

Com seu romance, Marlínski provou que o cotidiano escravocrata da Rússia do século XVIII poderia dar um material rico e original para uma história de luta contra opressão e injustiça, abrindo o caminho para outros escritores russos. 


\section{Aleksandr Púchkin e o gótico}

O poeta Aleksandr Púchkin (1799-1837), quem Gógol considerava seu mentor literário, também mostrou seu interesse pelo romance gótico. De acordo com o pesquisador Modzalévski, na biblioteca do poeta, havia cinco tomos de "Biblioteca de romancistas" (Ballantyne's novelists 'library), de John Ballantyne (1774-1821), um editor escocês e colega de Walter $\mathrm{Scott}^{84}$. Entre as obras dessa série de livros estavam $O$ castelo de Otranto, de Walpole, O velho barão inglês, de Clara Reeve, junto aos ensaios biográficos de Scott sobre esses autores.

Púchkin admirava Melmoth ou o homem errante, de Maturin: o seu primeiro contato com essa obra ocorreu já em 1823, em Odessa. Tendo lido o livro no original, o poeta ficou impressionado com o romance de Maturin na época em que a obra ainda era pouco conhecida na Rússia; por isso, mencionando o herói Melmoth, no terceiro capítulo do seu romance em verso, Eugênio Oneguin, como "um peregrino sombrio" (brodiága mrátchnyi), ele precisou explicar para os seus leitores quem era essa personagem, usando uma nota de rodapé: "Melmoth é uma obra genial de Maturin ${ }^{85 "}$ - uma observação polêmica para os críticos do seu tempo e para alguns do tempo posterior. A razão do interesse de Púchkin por Melmoth estava, provavelmente, no fato de que o caráter demoníaco do protagonista do romance juntava em si as feições fundamentais do homem nobre, inteligente e decepcionado do início do século XIX: para o poeta, os termos "byroniano" e o assim chamado "melmótico" eram quase sinonímicos. O começo de Oneguin lembra vagamente o início do romance de Maturin: um jovem sobrinho e o único sucessor de um tio rico está se apressando para visitar o parente quando descobre que ele está à beira da morte. Algumas feições de Melmoth podem ser traçadas em vários poemas puchkinianos, como, por exemplo, "O demônio".

A obra de Púchkin mais próxima da tradição gótica é A dama de espadas (1834), publicada dois anos mais tarde de Noites, de Gógol. Simpson considera essa novela, parcialmente, uma paródia do romance de terror, em alguns momentos parecida com o famoso romance de Jane Austen, A Abadia de Northanger (Northanger Abbey, 1817), que ridiculariza os clichês góticos ${ }^{86}$. Podemos concordar com o estudioso: nos anos 1830, a moda do gótico,

\footnotetext{
84 MODZALÉVSKI, B.L. Biblioteka Púchkina: Nóvye materialy. Moskvá: Jurnálno-gazétnoe ob”'edinénie, 1934. pp. 985-1024.

85 ALEKSÉEV, 1983. Disponível em: <http://thelib.ru/books/alekseev_m/chrmetyurin_i_ego_melmot_skitalecread.html>. Acesso em: 20 jun. 2015.

${ }^{86}$ SIMPSON, 1986, p. 74.
} 
na Rússia, entrou em declínio e os temas característicos do gênero puderam ser entendidos melhor sob a luz da paródia.

A novela trata de um jovem herói que é obcecado por jogos de cartas. O sobrenatural tem um papel proeminente na história: o herói acredita que, para ganhar o jogo, ele precisa saber uma combinação certa de cartas que pode adquirir da velha condessa. Uma das personagens importantes para o enredo é o conde St. Germain, um aventureiro da época do Iluminismo, uma figura popular nos romances góticos que também aparece em Melmoth. Mas, apesar de vários temas góticos, A dama de espadas não pertence exatamente ao gênero. O protagonista Hermann é um herói de moralidade dupla, mas não é um herói demoníaco. O final da novela, ao contrário do romance gótico, não tem uma explicação única dos eventos sobrenaturais (fantástica ou realista), mas é aberto para as suposições dos leitores. O público poderia acreditar que Hermann foi amaldiçoado ou preferiria imaginar que o protagonista perdeu sua mente porque era obcecado pelo truque de cartas desde o início. A condessa, a propósito, não suporta os romances góticos, fato que ela menciona na conversa com seu sobrinho, ao pedir que traga os romances em que os filhos não matam seus pais e não há afogados (mais uma alusão fina a Melmoth).

É interessante também salientar que Vatsuro fala sobre a possível intertextualidade entre Púchkin e Horace Walpole em Contos de Belkin ${ }^{87}$. Nessa coletânea, Púchkin estudava com muita atenção o problema da representação do comportamento humano nas circunstâncias extraordinárias. Assim como Walpole, ele também misturava o cômico e o trágico na obra e usava expressões populares.

Poucos escritores russos do século XIX não tinham conhecimento do "romance de terror e mistério". As reedições provincianas dos romances góticos foram publicadas até os anos 1830. O tributo à tradição gótica foi pago por Karamzin, Bestújev-Marlínski, Jukóvski ${ }^{88}$, Púchkin, Lérmontov e muitos outros autores menos conhecidos. Entre os apreciadores, estavam também Dostoiévski, Tolstói, Leskov.

Muitos pesquisadores, tratando a literatura gótica com negligência, negam sua influência na literatura russa clássica, exagerando a significação dos clássicos "canônicos"

\footnotetext{
${ }^{87}$ VATSURO, 2002, p. 44.

${ }^{88}$ Alguns pesquisadores, como, por exemplo, CHAMBINAGO (Gógol' e Goia. In GONTCHAROV (Org.). Gógol': Pro et Contra. Tomo I. Sankt-Peterburg: Rússkaia khristiánskaia gumanitárnaia akadémia, 2009), até consideram Vassíli Jukóvski como um dos poetas russos de primeira linha mais próximos da poética do gótico. É importante lembrar que Gógol, descrevendo o fantástico em Noites, coloca-o em conexão direta com as baladas terríveis de Jukóvski. Já no prefácio para o primeiro livro de Noites, o editor fictício, Rúdyi Pankó, diz que ele tenta "cavar os velhos tempos, trazer alguns terrores" (GÓGOL, 1976, tomo I, p. 10).
} 
para sua história, como Byron, Schiller, Hoffmann, ao mesmo tempo esquecendo que esses autores, assim como os russos, deleitavam-se com a leitura de romances góticos e adaptavam as ideias dessa tradição literária em suas obras. Melmoth, junto aos heróis byronianos, inspirou o futuro "homem supérfluo" - um tipo literário especial que surgiu na comédia de Aleksandr Griboédov, A desgraça de ser inteligente (Gore ot umá), e que continuou aparecendo até nos romances de Dostoiévski na forma de um "herói-ideólogo".

A partir dos anos 30 do século XIX, o romance gótico foi constantemente criticado nos jornais, ele foi travestido ${ }^{89}$ e parodiado ${ }^{90}$. O público também começou a perder o interesse pelo romance, preferindo obras mais curtas como novelas e contos. Mas, apesar disso, a tradição do gótico continuava a existir na consciência literária da época. Não podemos procurar na literatura russa do período romântico exemplos puros do romance gótico. Mas podemos falar em semelhança tipológica, além das refrações dos motivos, das personagens e do cronotopo góticos que permaneceram a partir dos anos 1830 .

\footnotetext{
${ }^{89}$ Falamos em travestimento no sentido de aproveitamento polêmico da herança gótica - dos caráteres, enredos, motivos e técnica narrativa.

90 A paródia apresenta, como quer Tyniánov, uma função essencial na evolução e na transformação das diferentes formas literárias, na medida em que se interpõe no tênue equilíbrio entre o ato pessoal do artista de suplantação e a inscrição da continuidade histórico-literária”. (apud CAVALIERE, 2009, p. 18).
} 


\section{III.}

\section{A poética do gótico em Noites em uma granja perto de Dikanka de Nikolai Gógol}

\section{Gógol e o gótico: as pesquisas acerca do tema}

Essencialmente um escritor eclético, nos anos 1830, Gógol "captava diferentes influências, que, nessa época de transição, tinham livre acesso em seu trabalho criativo e constituíam uma gama enorme de elementos que desempenhavam papel importante em sua liberdade de criação ${ }^{91 "}$. É provável que a sua percepção do estilo gótico (na arquitetura e na literatura) também contribuiu para a sua visão do mundo e da arte, especialmente na juventude, no período mais "romântico" da sua criatividade ${ }^{92}$.

Por enquanto, não há muitas pesquisas sobre o tema "Gógol e o gótico", provavelmente porque a questão da influência direta do gótico literário em Gógol é controversa: documentos que poderiam provar o interesse do escritor pelos textos góticos não foram encontrados, embora Gógol vivesse na época em que o sucesso dos romances de terror na Rússia era indubitável, como vimos anteriormente. Há pesquisadores que, inclusive, negam a influência do gótico em Gógol:

Embora um filho da era gótica e, sem dúvida, familiar com a tradição britânica, Gógol foi atraído à escola de E. T. A. Hoffmann e o fantástico. Como vimos, o fantástico e o gótico não são a mesma coisa de qualquer modo. Os romances góticos são fundamentados na realidade cotidiana de percepções comuns e os ambientes "reais". Um monge pode desejar um menino e fazer um pacto com o diabo, disfarçado de uma tentadora rechonchuda, mas o nariz nunca poderia perambular nos corredores de Udolpho $^{93}$.

\footnotetext{
${ }^{91}$ CAVALIERE, 2009, pp. 21-22.

${ }^{92}$ Para a leitura mais profunda sobre o romantismo em Noites, ver MANN, I. V. Usslojnénie romantitcheskovo mira v "Vetcherakh na khutore bliz Dikanki". In Moskvá: RGGU, 2007. pp. 381-388. Rússkaia literatura XIX veka. Épokha romantizma.

93 SIMPSON, 1986, p. 96.
} 
Os argumentos do estudioso Simpson não nos parecem convincentes. Em primeiro lugar, a influência dos romances góticos em Hoffmann, uma das figuras importantes para a formação da poética gogoliana, já foi estudada detalhadamente. $\mathrm{O}$ romance $O$ Elixir do Diabo (1816) é considerado uma adaptação genial hoffmaniana do romance de Lewis, $O$ Monge ${ }^{94}$. Em segundo lugar, Simpson cita como prova somente uma das novelas gogolianas, O Nariz, deixando sem atenção os textos como A Terrivel Vingança, A noite da véspera do dia de Ivan Kupala, Viy, que são bem diferentes dos contos petersburgueses em relação ao seu enredo, à composição e às personagens.

Os outros autores não concordam com a opinião de Simpson e efetuam análises comparativas entre textos gogolianos e romances góticos ingleses. Propõe-se citar aqui algumas pesquisas já realizadas que põem em foco a poética do gótico em Gógol.

Uma das primeiras vezes em que o tema do nosso interesse é mencionado foi na revista inglesa The Modern Language review ${ }^{95}$. O autor do estudo discute as conexões de Gógol com a literatura inglesa, inclusive com alguns autores góticos. O consagrado pesquisador do estilo gogoliano, V. Vinográdov, menciona, em um dos artigos, que Gógol estava interessado na obra de Charles Maturin:

\begin{abstract}
Melmoth ou o homem errante vagueava pelas suas obras também, deixando seus traços em $O$ Retrato e em Almas mortas. As imagens de Maturin devem gerar mais impressão na obra de Gógol no tempo quando ele achava seu caminho no naturalismo, aliás, também através de uma faixa estreita de interesse pelas formas do gênero 'romântico-horrível' (romantitcheskiujássnyi $)^{96}$.
\end{abstract}

A ligação da obra gogoliana com Melmoth é também analisada atenciosamente no prefácio à edição russa do romance de Maturin, feita por M. Alekséev. Além de conter uma lista grande dos autores ingleses, franceses e russos que, de um modo ou de outro, usaram a imagem sombria de Melmoth como sua fonte de inspiração, o artigo mostra as raízes "melmóthianas" em Gógol, também em O Retrato e no romance Almas Mortas. Segundo Alekséev, já os contemporâneos do escritor perceberam que a avareza demoníaca do

\footnotetext{
${ }^{94}$ ROBERTS, L. M. Literary nationalism in German and Japanese Germanistik. Peter Lang, 2010. pp.114-116.

${ }^{95}$ SIMMONS, E.J. Gogol and English Literature. In The Modern Language Review, Vol. 26, №4 (Oct., 1931). pp. $445-450$.

${ }_{96}^{9}$ VINOGRÁDOV, V.V. Ízbrannye trudy. Poètika rússkoi literatury. Moskvá: Naúka, 1976. pp. 45-46.
} 
personagem Pliúchkin, de Almas Mortas, poderia ser parcialmente "emprestada" do velho John Melmoth. Alguns paralelos no enredo de O Retrato com Melmoth podem testemunhar o conhecimento do romance de Maturin por Gógol. Por exemplo, no retrato de John Melmoth, o jovem herói anota, em primeiro lugar, o olhar forte: parece que a imagem está viva. Em Gógol, observa-se o mesmo foco nos olhos no retrato do velho usurário Petromikháli. Na impressão do artista Tchartkov, os olhos pintados estão guardando uma parte da vida do seu dono. Em Maturin, o tio moribundo manda o sobrinho para o quarto abandonado, em que se encontra o retrato, avisando-o que o original ainda está vivo, e pede queimar o quadro. Em Gógol, o próprio artista joga o retrato do velho misterioso no fogo. Em ambos, Maturin e Gógol, a pessoa no retrato permanece viva e aparece diante dos donos da pintura amaldiçoada através das portas trancadas. Porém Alekséev anota que o tema do mau olhar era muito divulgado nos textos românticos europeus e russos, por isso não se pode confirmar por completo a influência direta de Maturin em Gógol ${ }^{97}$.

Um dos estudos recentes, publicado na antologia Tradição gótica na literatura russa, também analisa a questão da relação de $O$ Retrato com a obra de Maturin. A autora desta pesquisa, Samoródnitskaia, além de sublinhar o mesmo tema dos olhos vivos e da presença do sobrenatural em ambos os textos, faz observações biográficas interessantes sobre a possibilidade do contato de Gógol com a tradição gótica sentimental na infância: "N.V. Gógol podia ter tido conhecimento da obra de Ann Radcliffe no liceu de Niêjin. O único aluno do liceu que menciona Radcliffe é N.V.Kúkol'nik ${ }^{98}{ }^{99}$ ". Segundo a estudiosa, os romances góticos já faziam parte dos textos populares da literatura de massa (popular). As tramas típicas e os métodos literários foram dominados não somente pela literatura de massa, mas também pela literatura séria ${ }^{100}$ ". A estudiosa pensa ser possível que Gógol tenha lido os romances de Ann Radcliffe.

Outro artigo da mesma antologia, escrito por Viktória Málkina, procura pontos de comparação na novela gogoliana, A Terrivel Vingança, com o romance de H. Walpole, O castelo de Otranto, mostrando muitas peculiaridades que esses dois autores têm em

\footnotetext{
${ }^{97}$ ALEKSÉEV, 1983. Disponível em: <http://thelib.ru/books/alekseev_m/chrmetyurin_i_ego_melmot_skitalecread.html>. Acesso em: 27 jun. 2015.

${ }^{98}$ Néstor Vassílievitch Kúkol'nik (1809-1868) - escritor e poeta russo da primeira metade do século XIX, amigo de N.V.Gógol.

99 SAMORÓDNITSKAIA, Ekaterina. N.V. Gógol' $i$ Tch. R. Mèt'iurin. In TAMÁRTCHENKO, N., ZÚSSEVA, V., MÁLKINA, V. et.al. (org.) Gotitcheskaia traditsia v rússkoi literature. Moskvá: Izdátel'ski Tsentr RGGU, 2008. p. 89.

100 Idem, Ibidem.
} 
comum $^{101}$. Ela atribui as seguintes feições góticas à novela ucraniana de Gógol: a presença de um castelo - necessária para o romance de terror, que no fim da obra é destruído pelas forças sobrenaturais; a composição da obra (sistema de narrativas inseridas e sua ordem primeiramente se fala sobre o presente e os acontecimentos e depois sobre o passado e as razões), os temas de incesto e de vingança. A mesma novela de Gógol foi incluída numa coletânea recém-publicada: Novela gótica russa do século XIX ${ }^{102}$. O organizador da coletânea não explica o critério da sua avaliação dos textos como góticos, mas a inclusão de $A$ Terrível Vingança, provavelmente, pode servir como uma prova indireta da presença dos elementos góticos em Noites.

O livro inglês The Gothic-fantastic in Nineteenth-century literature, publicado em 1999, contém dois artigos sobre Gógol acerca do tema. O primeiro, de Priscilla Meyer, é uma análise paralela de duas novelas gogolianas - a ucraniana Viy, de 1833, e a petersburguesa $O$ Nariz, de 1834. Não focando o contexto gótico, ela, porém, contribui com o estudo do fantástico e insólito em Gógol: “as forças malignas nas novelas ucranianas tornam-se invisíveis nos contos petersburgueses. Elas podem ser invisíveis para as personagens que são caracterizadas pela sua visão nublada [...], mas o leitor é capaz de capturar o mundo transcendental não realizado ${ }^{103}$ ". Meyer também traz uma observação curiosa sobre o papel da música em Viy. A pesquisadora explica que o protagonista Khomá, no seu primeiro encontro com a bruxa, depois de bater na mulher até a morte, ouve a voz da jovem, que parece o tinido de sinetas. Esse som reaparece, antes dele ir à igreja, onde se desenrola o final trágico. A observação é importante para o tema do gótico: a melodia estranha é o tema constante de Melmoth, em que todas as personagens tentadas pelo vilão ouvem a mesma música, que representa o perigo mortal.

O segundo artigo da antologia, de Ignat Avsey, traça os elementos góticos em Dostoiévski e Gógol. A proximidade do primeiro da poética do horror é indubitável e pode ser provada por várias anotações nos seus diários e reminiscências nos romances: "Dostoiévski concentrou-se no labirinto interno mental dos seus heróis, e desenvolveu aquilo que podia ser chamado o gótico psicológico, que já tinha sido explorado por Matthew Gregory Lewis e

\footnotetext{
${ }^{101}$ MÁLKINA, Viktória. "Stráchnaia mest"” i “Zámok Otranto” Uólpola. In TAMÁRTCHENKO, op. cit., pp. 106-111. ${ }_{102}$ BUTÚZOV, A.E. (Org.) Rússkaia gotítcheskaia póvest’ XIX veka. Moskvá: Tri kvadrata, 2008.

103 MEYER, Priscilla. Supernatural Doubles: Vii and The Nose. In CORNWELL, Neil (Org.). The Gothicfantastic in Nineteenth-century Russian literature. Amsterdam - Atlanta: Rodopi, 1999. p. 209.
} 
Charles R. Maturin ${ }^{104 », . ~ N o ~ c a s o ~ d e ~ G o ́ g o l, ~ o ~ p e s q u i s a d o r ~ m e n c i o n a ~ T c h i ́ t c h i k o v ~ e ~ K h l e s t a k o v ~}$ como os personagens demoníacos que podem ser também vistos como os vilões góticos. Ele nomeia O Inspetor Geral e Almas Mortas "um díptico gótico ${ }^{105 ", ~ e ~ c o m p a r a ~ a ~ t r a j e t o ́ r i a ~ d e ~}$ Tchítchikov, embora de um modo irônico, quase como de Judeu errante, um personagem bíblico profundamente gótico pela sua natureza: “[...] ele é condenado a vaguear pela terra, executando os ritos sagrados capitalistas de aquisitividade ${ }^{106}$. . Esse pesquisador também é um dos primeiros a citar as novelas de Noites em uma granja (Uma noite de maio, ou uma moça afogada e A Terrivel Vingança) como textos góticos. Porém ele não se aprofunda muito no tema do nosso estudo.

Embora o auge do interesse do público russo pelo romance de terror ocorresse nos anos de $1820^{107}$, exatamente na época em que Gógol estava escrevendo Noites em uma granja, não há menções às obras desse gênero em seus livros e cartas. Nos artigos críticos de Gógol, também não há referências aos clássicos do romance gótico (porém há muitas reflexões sobre a arquitetura gótica ${ }^{108}$ e sobre a história da Idade Média ${ }^{109}$ ). Tendo em consideração a ideia romântica sobre a síntese das artes, podemos supor que os ideais estéticos de Gógol, em relação à arquitetura, também podem ser aplicados na sua obra literária - tópico a que será dedicado um dos itens do presente capítulo ${ }^{110}$.

A própria visão de mundo de Gógol, e, especialmente nas novelas ucranianas, nos faz acreditar que ele está próximo à tradição gótica. Citemos para isso uma análise de Noites feita pelo semioticista Lótman: "Nos seus contos [...] atuam pessoas alegres, bonitas, e fortes que heroicamente superam os obstáculos em nome do amor, da liberdade e da pátria. Elas entram abertamente numa luta contra o mal que se encarna nas imagens da "força impura" dos diabos e das bruxas ${ }^{111 "}$. Ao que parece, a obra gogoliana possui muitas características ideológicas do gênero gótico. Há em Gógol uma visível oposição entre o bem e o mal, com o foco nas descrições do mal e, em alguns casos, a romantização do mal - procedimento

\footnotetext{
${ }^{104}$ AVSEY, Ignat. The Gothic in Dostoevskii and Gogol: the British connection. In CORNWELL, op. cit., pp. 214-215.

${ }^{105}$ Idem, Ibidem, p. 230.

${ }^{106}$ Idem, Ibidem, p. 228

${ }^{107}$ VATSURO, 2002, p. 372.

${ }^{108}$ Os artigos de Gógol mais importantes sobre a arquitetura gótica são "Sobre a arquitetura de hoje" ( $O b$ arkhitekture nynechnevo vrémeni, 1831) e "Escultura, pintura e música" (Skulptura, jívopis e múzyka, 1835).

109 "A história da Idade Média de jeito nenhum pode ser chamada de enfadonha. Em nenhuma outra história há tanta variedade, tanta ação viva, tantos contrastes fortes, tanto esplendor estranho como nela" (GÓGOL, N. V. O srédhikh vekakh. In Pólnoe sobránie sotchinenii v 14 tomakh. Tomo 8. Artigos. Moskvá - Leningrad: AN SSSR, 1952, p. 16).

${ }^{110}$ Ver o item "Gótico literário, arquitetura e artes plásticas", pp. 142-169 da presente dissertação.

${ }^{111}$ LÓTMAN, Iúri. M.Utchébnik po rússkoi literature dliá srédnei chkoly. Moskvá: Iazykí rússkoi kultury, 2000. p. 171, grifo nosso.
} 
tipicamente gótico. É forte a presença do elemento fantástico e a tentativa, frequentemente frustrada, dos heróis de superar restrições que lhes são impostas pela sociedade. Sua percepção do gênero, provavelmente, foi marcada pelas interpretações do gótico de críticos russos do início dos anos 1800.

Oscilando na margem entre o alto e o baixo, real e mitológico, o conto de terror atraía o escritor pelo seu caráter fronteiriço. A poética gogoliana, em sua essência, é baseada na vivência tensa da ideia da margem, fronteira como um princípio de organização da forma e da imagem ${ }^{112}$. Certamente, o gótico estava presente na consciência literária do escritor, apesar de estar incorporado nas suas obras de modo transversal e enviezado.

${ }^{112}$ SOFRÓNOVA, 2010, p.8. 


\section{O espaço gótico}

Se, à noite, acontecer de você sair de casa por alguma razão, logo pensa que um habitante do outro mundo deitou na sua cama ${ }^{113}$.

(Nikolai Gógol. A noite da véspera do dia de Ivan Kupala, 1831).

O espaço e o tempo na literatura definem nossa "percepção da época, comportamento das pessoas, sua consciência, o ritmo da vida, sua atitude às coisas ${ }^{114 \%}$. Assim, através do sistema das relações espaço-temporais, pode-se definir não só a consciência de um autor, mas a consciência global da época ou da cultura. Categorias do espaço e do tempo podem ser consideradas fundamentais para a formação do enredo em ficção gótica. O próprio gênero, conforme Botting, "se apoiava nos ambientes, nos recursos e nos acontecimentos ${ }^{115}$ ". As demais características do gótico, tais como seu sistema de personagens, os temas e os motivos recorrentes, são dependentes dessas duas ${ }^{116}$.

O fenômeno de um espaço gótico se transforma em um cronotopo a medida que ocorre o desenvolvimento das suas específicas características do espaço e tempo ${ }^{117}$. É típico o seu isolamento do mundo real. Ele pode ser atingido ou com um deslocamento da ação para um ambiente exótico - por exemplo, para outro país ou para outro tempo. Tal deslocamento faz os acontecimentos fantásticos do enredo mais verossímeis. Em Noites, Gógol usa um ambiente exótico - a Maloróssia era pouco conhecida na Rússia da época e era considerada um local incomum.

As observações do formalista russo Boris Eikhenbaum sobre o espaço na poética gogoliana coincidem também com o conceito de isolamento do espaço na tradição gótica:

O estilo do grotesco exige, em primeiro lugar, que a situação ou acontecimento descritos sejam confinados num mundo fantasticamente minúsculo das emoções artificiais [...], completamente isolado da realidade externa, da vida real, e, em segundo lugar, que isso seja feito não com um

\footnotetext{
${ }^{113}$ GÓGOL, 1976, tomo I, p. 40.

${ }^{114}$ GURÉVITCH, A. I. Kategórii srednevekóvoi kul'tury. Moskvá: Iskusstvo, 1972. p. 84.

${ }^{115}$ BOTTING, 1996, p. 45.
}

${ }^{116}$ MILES, Robert. The 1790s: the effulgence of Gothic. In HOGLE, 2002, p. 41. Analisando somente os títulos das obras góticas na Grã Bretanha, por meio do prontuário English Novel 1770-1829, o estudioso chega a uma conclusão que o conceito de espaço no seu significado físico é crucialmente importante na poética do gênero. Assim, muitas obras têm menções às localidades geográficas: ruínas, rocha, Alpes, caverna assombrada e localidades arquitetônicas: castelo, abadia, convento, casa antiga.

${ }^{117}$ ZALÓMKINA, 2006, p. 38. 
objetivo didático ou satírico, mas com o objetivo de abrir o espaço para um jogo com a realidade, para decomposição e deslocamento livre dos seus elementos, assim que as proporções e conexões usuais (psicológicas e lógicas) acabam sendo, nesse mundo [...] inválidas, e quaisquer pormenores podem crescer até os tamanhos colossais ${ }^{118}$.

É esse isolamento que se pode observar em toda a coletânea Noites em uma granja - é um mundo pequeno, bem delineado, cujas fronteiras não ultrapassam a Polônia. Para o organizador das novelas - o colmeeiro Rúdyi Pankó - toda a terra pode ser dividida em duas partes - desse lado de Dikanka (familiar, cotidiano, confortável) e do outro lado de Dikanka (estranho, alheio). Em Gógol, o sentimento de reclusão é, às vezes, atingido com o posicionamento do herói num espaço limitado. Outras vezes, isso não acontece, porque o sentimento de isolamento já é predeterminado pelas condições do mundo de Dikanka. Em Noites, os espaços góticos geram a atmosfera necessária, mas toda a ação se desenrola não diretamente dentro de um local, mas no espaço aos seus redores. Afirma essa hipótese a estudiosa Ol'ga Karandachova: “A casa como uma entidade em Gógol não se atualiza; seus heróis estão completamente concentrados num espaço aberto ${ }^{119}$ ".

Parece produtiva a definição do espaço gótico como cênico, porque tal definição traz associações com a potencial teatralidade do gênero ${ }^{120}$. Condicionalmente, é possível dividir todo este espaço no cotidiano (usual, real) - "o palco", o mágico (sobrenatural, fantástico, irreal) - "os bastidores" e a fronteira entre os dois - "o pano de boca". Os acontecimentos sobrenaturais, inclusive aqueles que somente são pressupostos, cumprem no gótico uma função de um atributo do espaço cênico. Isso significa que o elemento fantástico ${ }^{121}$ do enredo gótico é ligado, antes de tudo, à intensidade do espaço irreal.

A divisão nítida entre os mundos real e fantástico, na obra gogoliana, já foi mencionada por Iúri Lótman, na sua análise de Noites: "É fácil perceber que as cenas

\footnotetext{
${ }^{118}$ EIKHENBAUM, 1986, p. 60, grifo nosso.

${ }^{119}$ KARANDACHOVA, 1999, p. 59.

${ }^{120}$ Além do fato que Horace Walpole já tinha declarado sua fidelidade aos métodos teatrais de Shakespeare, um dos autores góticos mais famosos, Matthew Gregory Lewis, era muito popular na sua época como dramaturgo. Cf. HALE, Terry. French and German Gothic: the beginnings. In HOGLE, 2002, p. 71.

121 Para falar em fantástico, nós nos apoiamos nas ideias do filósofo russo Vladímir Solovióv (apud. CESERANI, 2006, p. 15). Segundo ele, o autenticamente fantástico "não deve nunca se apresentar, por assim dizer, de forma descoberta. As suas manifestações não devem impor a fé no sentido místico dos eventos humanos, mas apenas acenar, aludir a isso. Dentro do autenticamente fantástico, resta sempre uma possibilidade formal, exterior, de uma explicação simples, baseada em relações normais e habituais entre os fenômenos [...] Todos os particulares devem ter um caráter familiar e só a conexão do todo deve acenar para uma casualidade de outra espécie".
} 
cotidianas e fantásticas aqui, até nos limites de uma só novela, nunca se localizam no mesmo lugar. [...] eles se localizam não apenas em lugares diferentes, mas também em diferentes tipos de espaço ${ }^{122 \%}$. Na opinião de Lótman, esses dois espaços também são opostos um ao outro no sistema artístico de Gógol. Segundo ele, os dois mundos podem ser muito parecidos, mas sua semelhança é apenas superficial: o mundo maravilhoso finge ser ordinário, metaforicamente ele usa uma máscara.

Karandachova coloca o espaço da coletânea em um inteiro sistema de oposições. Além do real e irreal, ela destaca, nas novelas, o espaço da natureza e da sociedade de Dikanka (também oposto ao mundo da capital, Petersburgo), o espaço dos heróis e do autor, os espaços final e infinito, aberto e fechado ${ }^{123}$.

É difícil concordar por completo com essa ideia de oposição total dos dois espaços: parece-nos mais coerente o raciocínio do estudioso Smirnov, de acordo com o qual os mundos empírico e espiritual, em Gógol, estão em relação de "correspondência espelhada um com outro $^{124 \%}$. Ou ainda se pode citar a opinião de Mann: "na sua busca na área da fantástica, Gógol desenvolve [...] o princípio de paralelismo entre o fantástico e o real ${ }^{125 "}$.

Seguindo esse modo de raciocínio, não somente contrapomos os dois espaços, mas também pressupomos a sua concordância em vários níveis do texto, principalmente no nível dos personagens e no nível do enredo. O espaço e o tempo em Gógol entram nas relações complexas que geram uma realidade artística específica, uma das feições principais da qual é uma mistura filigranada do excepcional e do ordinário, do fantástico e do real. Segundo Zamánova, "para Gógol, a granja não é somente um ponto do espaço geográfico real, mas também um "ponto" conotativo mais importante do mundo artístico de Noites, através do qual é possível uma entrada no espaço irreal das novelas ${ }^{126 "}$.

Todos os enredos gogolianos podem ser lidos nos dois níveis: no nível superficial dos eventos, empírico, e no nível interno, existencial. Um local que une e, ao mesmo tempo, separa os dois níveis chamamos de uma fronteira, que nas novelas assume muitas formas

\footnotetext{
${ }^{122}$ LÓTMAN, I. M. V chkole poètitcheskovo slova: Púchkin, Lérmontov, Gógol'. Kniga dliá utchítelia. Moskvá: Prosvechtchénie, 1988. pp. 259-260.

123 KARANDACHOVA, Olga. Khudójestvennoe prostranstvo “ukraínskikh” sbórnikov N.V. Gógolia ("Vetcherá na khútore bliz Dikanki", "Mírgorod"). Tese (doutorado em filologia). Tver': Universidade estatal de Tver', 1999. p. 20.

${ }^{124}$ SMIRNOV, I.P. Formirovánie i transformírovanie smysla v ránnikh tékstakh Gógolia ("Vetcherá na khútore bliz Dikanki”) In Russian literature, 1979, №7, p. 586 apud. GONTCHAROV, S.A. Son - duchá, liubov’ sem 'iá, mujskóe - jénskoe v rannem tvórtchestve Gógolia. In: Peterburg: Obrazovánie, 1993. p. 25

${ }^{125}$ MANN, 1988, p. 76, grifo nosso.

${ }^{126}$ ZAMÁNOVA, 2000, p. 32.
} 
diferentes. É o único espaço da obra que pode possuir as duas características opostas ao mesmo tempo. Para tornar nossa linha de raciocínio mais clara, parece-nos útil aplicar o seguinte esquema do espaço nas novelas ucranianas:

Esquema 1. Organização do espaço em Noites em uma granja.

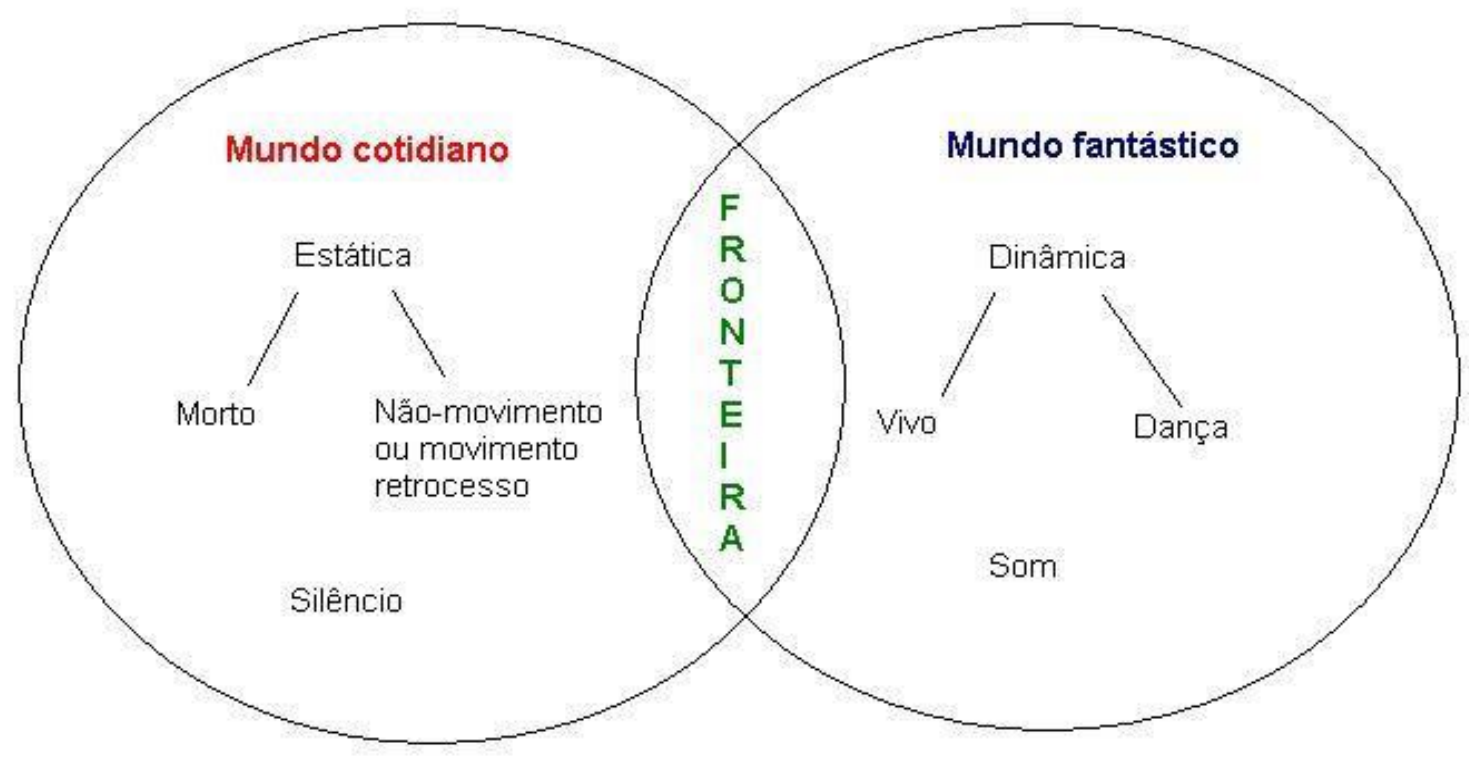

Vinográdov considerava A Terrível Vingança uma das novelas mais inovadoras do então jovem escritor. Nas suas palavras, "Em A Terrivel Vingança é evidente não apenas uma proporção funcional dos estilos poéticos que se manifestaram antes na poética de Gógol, mas também nela se destaca, de um modo indefinido, uma inclinação do artista a um estilo 'romântico-horrível' (romantítcheski-ujássnyi) ${ }^{127}$ "'.

O primeiro ponto para comparação de dois espaços na novela é um grau de movimento neles (sua estática/dinâmica). Segundo Lótman, para o mundo cotidiano, em Noites, é característica "uma retardação da dinâmica da ação que pode ser traduzida numa língua condicional dos gestos, aparentada à pantomima ${ }^{128 \%}$. Pode-se observar o efeito de retardamento já no primeiro capítulo de A Terrível Vingança, na cena de casamento. A primeira vista, pode parecer que a cena está cheia de movimento: muitos convidados chegaram à casa do esaul, viera também, em seu cavalo, o cossaco Danilo com sua esposa.

\footnotetext{
${ }^{127}$ VINOGRÁDOV, 1976, p. 216.

${ }^{128}$ LÓTMAN, 1988, p. 262.
} 
Mas o movimento é retardado a cada momento através da fala do narrador que insere novos detalhes, criando no leitor uma impressão de uma canção épica, lenta e majestosa. Andréi Bélyi, na sua análise de $A$ Terrível Vingança, assim fala do estilo desse trecho: "Gógol amava, estudava, sabia bem as canções líricas ucranianas; A Terrivel Vingança é impregnada pelos sons das melodias populares ${ }^{129}$ ":

Com sua jovem mulher Katerina e o filho de um ano, chegou também o irmão adotivo de esaul, Danilo Burul'bash, da outra margem do Dnepr, onde ficavam suas terras, entre duas montanhas. Maravilhavam-se os convidados com o rosto branco de pani Katerina, suas sobrancelhas negras como veludo alemão, e a elegante saia de lã azul e as botas de tacões de prata; porém ainda mais se admiravam por não ter chegado com ela o velho pai $^{130}$.

A estática é característica também para a descrição do rio Dnepr antes dos acontecimentos fantásticos: É também encantador o Dnepr nas noites quentes de verão quando tudo adormece: o homem, o animal, a ave; e só Deus poderoso contempla o céu e a terra $^{131}$.

O próprio movimento no espaço real em Gógol é parecido com o movimento das personagens no conto maravilhoso, porque todo o desenrolar do enredo acontece nas paradas dos heróis, nunca durante seu deslocamento de um lugar para outro ${ }^{132}$. Na cena de fuga do feiticeiro, observa-se uma não-existência do movimento, ou ainda um movimento retrocesso: Tocou o cavalo de volta para Kiev e depois de um dia apareceu uma cidade; mas não era Kiev, era Gálitch, uma cidade ainda mais distante de Kiev que Chumsk ${ }^{133}$. Confirma Arlete Cavaliere que "os seres e as coisas gogolianas não conhecem outro tipo de animação, de vida, que não seja "estranha" e "sobrenatural". Daí a frequente comparação nos inícios do século XX entre os heróis gogolianos e os autômatos e bonecos de cera ${ }^{134 \text { ", }}$

É curioso notar que o movimento prevalecente em vários heróis da coletânea gogoliana é um olhar (uma volta) para trás, motivada pelo seu medo diante do sobrenatural, seguida por uma petrificação. Isso é uma reação principal do representante do mundo "real"

\footnotetext{
${ }^{129}$ BÉLYI, 1934, p. 74.

${ }^{130}$ GÓGOL, 1990, p. 44.

${ }^{131}$ Idem, Ibidem, p. 70.

${ }^{132}$ Uma peculiaridade também característica para o romance ulterior Almas Mortas (1842).

${ }^{133}$ GÓGOL, op. cit., p. 79.

${ }^{134}$ CAVALIERE, Arlete. A magia das máscaras. In GÓGOL, op. cit., p. 181.
} 
no seu encontro com algum fenômeno do mundo "alheio". Por exemplo, isso acontece quando Danilo e os seus cossacos veem os mortos que estão saindo da terra: De repente, os remadores deixaram cair os remos e arregalaram os olhos imóveis. Também pan Danilo parou: o medo e o frio penetraram nas veias dos $\operatorname{cossacos}^{135}$. Os heróis param nos seus lugares quando Katerina, já viúva, acaba por descobrir que o seu único filho está morto: Todos rodearam o berço e ficaram petrificados de horror, ao ver que nele jazia a criança sem vida. Nenhum deles proferiu um som sequer, sem saber o que pensar dessa vileza sem $\operatorname{par}^{136}$.

Assim acontece nas obras dos autores góticos também: por exemplo, em $O$ castelo de Otranto, de Walpole, quando o protagonista Manfred está parado por um momento ao ver um fantasma de enorme cavaleiro no castelo. Encontramos as cenas de petrificação quase em todas as novelas de Noites - de certo modo, essas cenas são os pequenos predecessores da famosa "cena muda" de $O$ Inspetor Geral.

Diferentemente do espaço cotidiano, o espaço mágico é repleto de movimento. Quando o cossaco Danilo se aproxima de um espaço fronteiriço - o castelo -, o leitor já começa a sentir a intensificação do movimento. Dentro do castelo, o cossaco observa as ações mágicas do feiticeiro: Sob o teto vão e vêm morcegos, e sua sombra projeta-se nos muros, pelas portas, pelo estrado. De repente, sem ranger, a porta se abre. Entra um homem de jupan vermelho e aproxima-se da mesa coberta com uma toalha branca ${ }^{137}$. No nível da linguagem, o movimento, nesse trecho, é marcado por Gógol por meio do advérbio "de repente" e através dos verbos no presente, que salientam a dinâmica: vão e vêm, projeta-se, se abre, entra etc.

No momento da fuga do feiticeiro do horrível bogatir $^{138}$, os objetos inanimados estão envolvidos na narrativa, reforçando ainda mais a sensação da dinâmica crescente: Parecia-lhe que tudo, em todas as partes, se movia para agarrá-lo: as árvores que o rodeavam no bosque escuro, como se fossem vivas, movendo as barbas negras e estendendo as ramas compridas, esforçavam-se por estrangulá-lo ${ }^{139}$. Ou ainda: até mesmo o caminho parecia correr por entre suas pegadas ${ }^{140}$.

\footnotetext{
135 GÓGOL, 1990, p. 48.

${ }^{136}$ Idem, Ibidem, p. 73.

${ }^{137}$ Idem, Ibidem, p. 58.

${ }^{138}$ Bogatir - herói do epos russo e dos mitos eslavos. Figura de grande estatura e força descomunal.

${ }^{139}$ GÓGOL, op. cit., p. 78.

${ }^{140}$ Idem, Ibidem.
} 
O cume do movimento é atingido, provavelmente, na própria terrível vingança, isto é, na cena da morte do feiticeiro: Mais uma vez o cavaleiro riu e atirou-o ao abismo. E todos os mortos saltaram ao abismo, agarraram o morto e lhe cravaram os dentes ${ }^{141}$.

O movimento no mundo fantástico é, às vezes, ligado a uma dança. No espaço cotidiano, a dança não acontece ou está associada ao movimento automático, morto, dos velhos de noventa e cem anos, no casamento do filho do esaul Gorobiétz, ou também das velhinhas na outra novela da coletânea, A feira de Sorótchinsy. Já uma dança verdadeira e seu poder absorvente são associados às forças infernais - uma observação feita por Mann ${ }^{142}$. Não por acaso, em A Terrível Vingança, a dança corresponde ao primeiro aparecimento do feiticeiro que já tinha dançado maravilhosamente o kozatchiók $k^{143}$. Katerina também dança nessa novela, mas enlouquecida - o estado de espírito que na poética gogoliana pode ser interpretado como fronteiriço entre o mundo real e o fantástico. Nessa cena, sua dança parece os movimentos demoníacos de uma bruxa:

[...] deslizava Katerina, olhando como louca para todos os lados, apoiando as mãos na cintura. Com um ganido batia com os pés sem ritmo e sem compasso fazendo soar os tações de prata das botas. As tranças entrelaçadas e negras agitavam-se sobre o colo branco. Como um pássaro e sem deter-se, ela voa agitando os braços, movendo a cabeça e parece que, extenuada, cairá estrondosamente ao solo ou abandonará, em vôo [sic] o mundo ${ }^{144}$.

A contraposição entre o silêncio e o som, no espaço gótico, está relacionada a uma oposição entre a estática e a dinâmica. O mundo cotidiano é silencioso e quieto; o mundo fantástico é cheio de ruído. Assim, na cena de volta de Danilo e Katerina para casa, é destacada a ausência de som: Uma luz suave brilha sobre a terra. É a lua que surge atrás da montanha ${ }^{145}$. Os amigos do protagonista não cantam. Não falam nem dos padres poloneses que já percorreram a Ucrânia ${ }^{146}$. Katerina embala o filho em silêncio ${ }^{147, "}$.

A aparição dos fenômenos fantásticos, ao contrário, é relacionada a um ruído forte. Quando Danilo está espiando o feiticeiro no castelo, os sons se fizeram mais fortes e mais

\footnotetext{
${ }^{141}$ GÓGOL, 1990, p. 80.

${ }^{142}$ MANN, 1988, p. 19.

${ }^{143}$ GÓGOL, op. cit., p. 44.

${ }^{144}$ Idem, Ibidem, p. 75.

${ }^{145}$ Idem, Ibidem, p. 46.

${ }^{146}$ Idem, Ibidem.

${ }^{147}$ Idem, Ibidem.
} 
cheios $^{148}$. O som intensifica na cena, quando um grande morto, o progenitor do feiticeiro, não consegue sair de terra: Ouve-se frequentemente nos Cárpatos um silvo como se fossem mil moinhos a rumorejar com as rodas na água. E então, no abismo sem fim que nenhum homem ainda ousou olhar, por se assustar só de passar perto, os mortos roem um morto ${ }^{149}$.

A fronteira no espaço gótico é "sugestiva" ${ }^{150 ", ~ u s a n d o ~ o ~ t e r m o ~ d e ~ V a t s u r o . ~ I s s o ~}$ significa que a fronteira sugere na obra um ambiente típico que provoca em leitores associações esperadas de mistério, de incerteza e de suspense. Gógol usa o princípio da personificação da fronteira, transformando-a num ser, objeto ou local ${ }^{151}$. Zamánova diz que o espaço geográfico de Noites é abundante de barrancos, fossos, abismos, precipícios, bosques, tabernas, palheiros destruídos, casas, que na travessia no espaço irreal "perdem seu significado cotidiano e começam a ser interpretadas como uma habitação da força impura, uma fronteira entre os mundos (o "próprio" e o "alheio") ${ }^{152, " . ~}$

A fronteira, em Gógol, é parecida com a do romance gótico: via de regra, é um lugar lúgubre, sinistro, que prepara a personagem, junto com o leitor, à transição. Esse espaço é fronteiriço entre o mundo real e o mundo fantástico - conceito que este gênero adotou, em parte, do conto maravilhoso. Afirma Vladímir Propp que "o reino a que chega o herói é separado da casa paterna por uma floresta impenetrável, um mar, um rio de fogo com uma ponte vigiada pelo dragão, ou um abismo, onde o herói cai ou desce. É o 'reino dos confins', 'o outro reino' ou 'nunca visto, ${ }^{153}$ ". Os dois conceitos - do espaço gótico e do mundo alheio do conto maravilhoso - estão misturados nas novelas de Noites, é difícil separar um do outro.

$\mathrm{Na}$ literatura de terror, a fronteira tradicional era o castelo. Isso se faz aparente através dos nomes dos romances góticos ingleses do século XVIII: O castelo de Otranto, de H. Walpole, O fantasma do castelo (The castle spectre), de M.G. Lewis, Os Castelos de Athlin e Dunbayne (The Castles of Athlin and Dunbayne, de A. Radcliffe) etc. Na terminologia do historiador literário russo Mikhail Bakhtin, o castelo cumpre, em qualquer romance, um papel de um cronotopo, "concentrando em si o tempo histórico tanto na sua aparência quanto na lenda que o cerca ${ }^{154 "}$.

\footnotetext{
${ }^{148}$ GÓGOL, 1990, p. 59.

${ }^{149}$ Idem, Ibidem, p. 80.

${ }^{150}$ VATSURO, 2002, p. 360.

${ }^{151}$ MELETÍNSKI, NEKLIÚDOV, NÓVIK et. al. Struktura volchébnoi skazki. Moskvá: RGGU, 2001. p. 148.

152 ZAMÁNOVA, 2000, p. 62.

${ }^{153}$ PROPP, Vladímir. As raízes históricas do conto maravilhoso. Trad. de Paulo Bezerra. São Paulo: Martins Fontes, 1997. p. 343.

154 BAKHTIN, M.M. Vopróssy literatury i estètiki: Isslédovaniia ráznykh let. Moskvá: Khudójestvennaia literatura, 1975. p. 394.
} 
A peculiaridade do romance gótico consiste no fato de que o castelo, como um espaço, possui também os significados metafóricos estáveis. Ele aparece na obra na véspera dos horrores da noite, exatamente como isso acontece em A Terrível Vingança: Fulgura no alto o céu claro da noite; mas não é o céu longínquo e nem o bosque azul que pan Danilo admira; está olhando para o promontório no qual se destaca, negro, o velho castelo ${ }^{155}$. O interior do castelo é cheio de traços de destruição e abandono. Ele é um símbolo materializado dos crimes e dos pecados dos seus antigos donos, é uma testemunha das tragédias que tinham acontecido nele há muito tempo, é um portador das superstições e preconceitos dos tempos "góticos", medievais.

Em Gógol, o castelo está presente somente em A Terrivel Vingança. Como também em $O$ castelo de Otranto, de Walpole, no final da obra, ele é destruído pelas forças sobrenaturais, junto a tudo que o cerca - e com muitas vítimas ${ }^{156}$.

Um procedimento estilístico importante no gótico é a criação por um autor de um ambiente emocional específico acerca do espaço-fronteira. $\mathrm{Na}$ opinião do pesquisador Haggerty, a função da paisagem, nos textos góticos, é criar um fundo emocional, em vez de dar uma descrição de um espaço acerca do herói ${ }^{157}$. É por isso que nesses textos aparecem adjetivos qualitativos como "magnífico", "esplêndido", "maravilhoso", "sublime” etc.; os quais fazem o leitor sentir o mesmo que o herói, e não tentar compreendê-lo. Assim como a personagem, o leitor vê um local colocado dentro de um espaço "normal", mas sente que ele é diferente, estranho, exala ameaça. Para Danilo de A Terrível Vingança, é suficiente olhar uma vez para o castelo para sentir uma preocupação: [...] atrás do bosque, negrejava um aterro e atrás do aterro se elevava um velho castelo. Três rugas vergaram sua fronte: a mão esquerda acariciava seu altivo bigode ${ }^{158}$.

Com a introdução do espaço-fronteira é formada a exposição do enredo: o herói se aproxima de um local estranho do qual começa a narrativa. É possível chamar esse procedimento artístico de uma "ativação" do espaço gótico. Em A Terrível Vingança, a ativação acontece através da fala de Katerina, que conta para seu marido uma estória do terrível feiticeiro: As estórias horríveis sobre o feiticeiro me assustaram. Dizem que nasceu tão pavoroso... e, desde pequeno, nenhuma criança quis brincar com ele ${ }^{159}$. Logo depois

\footnotetext{
155 GÓGOL, 1990, p. 56.

${ }^{156}$ Para saber mais sobre a relação entre $O$ castelo de Otranto de Walpole e A Terrível Vingança de Gógol, recomendamos ler MÁLKINA, 2008.

${ }^{157}$ HAGGERTY, 1989, p. 15.

${ }^{158}$ GÓGOL, op. cit., p 47.

${ }^{159}$ Idem, Ibidem, p. 46.
} 
disso, os heróis veem os mortos descarnados, os predecessores do feiticeiro, saindo da terra com os gemidos horríveis.

O pressentimento de algo sinistro e misterioso intensifica-se com uma descrição do interior do castelo: no quarto não há sequer uma vela acesa, no entanto há luz. Nas paredes vêem-se [sic] sinais estranhos. [...] Sob o teto vão e vêm morcegos, e sua sombra projeta-se nos muros, pelas portas, pelo estrado ${ }^{160}$.

Os fenômenos fantásticos da novela acontecem no castelo ou nos seus arredores (por exemplo, no cemitério onde estão apodrecendo seus antepassados malditos ${ }^{161}$ ). Nele o pan Danilo observa a transformação do sogro em um horrível feiticeiro: o rosto começou a se transformar: o nariz alongou-se e ficou penso por cima dos lábios; a boca num instante abriu-se até as orelhas; um dente despontou da boca, torto para o lado, e, de repente, diante dele surgiu aquele mesmo feiticeiro ${ }^{162}$. No castelo, o feiticeiro chama a alma da sua filha Katerina para tentar incliná-la a uma relação incestuosa: E como poderia estar de pé sem tocar o chão, sem apoiar-se em nada e através dela passar a luz rosada e refletirem-se na parede os traços? Eis que de repente ela move um pouco a cabeça transparente [...] Ah! É Katerina! ${ }^{163}$. O castelo, como um lar antigo da família de Katerina, possivelmente, é ligado também ao misterioso assassinato da sua mãe (a alma de Katerina menciona esse crime na sua conversa com o feiticeiro: Pai! - então ela crava os olhos claros no rosto do feiticeiro: - Por que matastes minha mãe? $\left.{ }^{164}\right)$.

O estudioso alemão Garleff Zacharias-Laghans, na sua monografia sobre a poética do romance gótico Der Unheimliche Roman um 1800 (O romance inquietante em 1800), compreende o castelo como uma realização figurada de um complexo de noções humanas em relação ao túmulo e tudo ligado a ele ${ }^{165}$. É difícil concordar com isso. Ao contrário, o castelo representa um espaço vivo, que reage aos acontecimentos do passado e do presente. Diferentemente do túmulo, ele não representa uma ideia de finalidade e gera associações de continuidade na vida póstuma. Daí surge, nesse espaço, uma possibilidade de uma presença de algo sobrenatural - um fantasma, um espírito ou um monstro.

\footnotetext{
${ }^{160}$ GÓGOL, 1990, 57-58.

${ }^{161}$ Idem, Ibidem, p. 47.

${ }^{162}$ Idem, Ibidem, p. 58.

${ }^{163}$ Idem, Ibidem, p. 59.

${ }^{164}$ Idem, Ibidem.

165 ZACHARIAS-LAGHANS, G. Der Unheimliche Roman um 1800. Bonn: 1968, apud. VATSURO, 2002, p. 86.
} 
Segundo Hogle, uma das características importantes do espaço gótico é seu mistério $^{166}$. Dentro desse espaço, estão escondidos alguns segredos do passado que perseguem as personagens, psicologicamente, fisicamente ou de algum outro modo. Eles podem assumir formas diferentes como os fantasmas, espectros ou monstros que aparecem para manifestar crimes ainda não desvendados ou alguns conflitos que não podem ser mais escondidos. Por isso, em A Terrível Vingança, o feiticeiro vê no castelo um misterioso fantasma que o assusta, sem perceber que é o vingador do seu antepassado distante. Somente no final da novela o leitor descobre que era o cossaco Ivan, assassinado pelo traidor Petró.

Galina Zalómkina considera o castelo um espaço cênico principal no gênero gótico ${ }^{167}$. Segundo ela, no enredo típico o protagonista, desde o início, está colocado numa situação de cativeiro, pré-definido pela estrutura complexa do castelo com seus labirintos, suas armadilhas e seus quartos escondidos. Segundo a pesquisadora, o enredo se desenrola ao redor das tentativas do herói de achar uma saída do castelo. Assim, no gótico, aparece o tema da prisão, em sentido mais genérico de qualquer restrição de liberdade do indivíduo, e de uma luta contra esse aprisionamento. O herói está conhecendo o castelo por dentro e não pode fugir dele a não ser que compreenda sua arquitetura interna e descubra seu mistério.

Partilhando, em alguns aspectos, com a opinião de Zalómkina, não se pode esquecer que o castelo não é o único espaço possível no romance gótico, sobretudo em se tratando do gótico russo, em que os castelos são raros. Os arredores tradicionais, sem dúvida, são uma parte importante do conceito da realidade autoral gótica - especialmente no período do surgimento desse gênero. Mas a evolução ulterior da tradição mostrou que o lugar de reclusão do herói podia ser diferente. Vatsuro salienta que, “Apesar da opinião divulgada, a própria descrição do castelo não é um tema gótico acentuado. Para ser tal, o castelo deve ser uma metáfora e levar em si um princípio sugestivo ${ }^{168,}$.

No começo do desenvolvimento do gênero, os autores tentavam provocar nos seus leitores o efeito de pavor majestoso diante da elevação e grandeza da arquitetura e da paisagem na qual os edifícios góticos foram colocados. A escuridão do castelo ou, em alguns casos, da catedral gótica, era uma feição característica para a atmosfera específica do romance desse tipo. Com o tempo, eles deixaram de ser os únicos espaços góticos e os escritores começam a explorar cavernas, bosques, cemitérios e outros lugares com alta concentração de energia espiritual.

\footnotetext{
${ }^{166}$ HOGLE, 2002, pp. 2-3.

167 ZALÓMKINA, 2006, p. 38.

${ }^{168}$ VATSURO, 2002, p. 360.
} 
As funções do castelo podem ser atribuídas a um velho monastério, uma abadia, uma grande casa aristocrata com torres, calabouços, portas secretas, antigos manuscritos, fantasmas etc. Ou até pode ser uma casa simples no centro de qualquer cidade. Um bom exemplo são os contos do escritor americano Edgar Allan Poe, um contemporâneo de Gógol. Na sua famosa A Queda da casa de Usher (1839), o papel de um espaço gótico é cumprido por uma casa que é situada numa estepe ordinária. Afirma o pesquisador Fisher que "os autores norte-americanos [...] não tinham castelos, abadias ou mosteiros como os autores europeus, e, portanto, o gótico americano tinha a tendência a colocar, em primeiro plano, outras variedades de tangíveis ${ }^{169 "}$.

A mesma observação pode ser feita sobre o romance gótico na Rússia: frequentemente os autores usavam casas abandonadas para criar um ambiente sombrio. Além disso, esse sentimento de reclusão não necessariamente pode ser atingido com o posicionamento do herói dentro do castelo ou outro espaço parecido.

Em A Terrivel Vingança, o castelo não é um único espaço-fronteira. $\mathrm{O}$ outro são as Cárpatos; exatamente nessas montanhas a narrativa passa do nível empírico para o nível mitológico. Isso não é por acaso, pois na mitologia as montanhas eram compreendidas como um lugar de moradia da força impura e um lugar ao qual era conectada a ideia do mundo alheio $^{170}$. Nas montanhas, o enredo para de ser uma história de traição na comunidade dos cossacos, se transforma num gigante drama cosmogônico. O início desse drama foi a traição de Caim (Petró) nos tempos remotos e o seu final será a terrível vingança de Deus, ligada à ideia do Juízo Final.

Tentando fugir dos seus inimigos, o feiticeiro viaja nas Cárpatos para escapar da Ucrânia. Mas elas se tornam em uma armadilha: Uma montanha atrás da outra, como correntes de pedra, transpassam a terra à direita e à esquerda e acorrentam-na como uma massa pétrea para que o mar ruidoso e bravio não se infiltre nela. As correntes de pedra [...] gigantescas, em forma de ferradura, se postam entre os povos da Galícia e da Hungria ${ }^{171}$. As montanhas na novela parecem uma prisão impenetrável, com as correntes, paredes gigantescas que não deixam ninguém passar para o outro lado. Por isso, para o narrador, o mundo atrás das montanhas é algo parecido com o além, um lugar nunca atingido por

\footnotetext{
${ }^{169}$ FISHER, 2002, p. 75.

${ }^{170}$ DMÍTRIEVA, 2011, p. 106.

${ }^{171}$ GÓGOL, 1990, p. 73.
} 
ninguém: $O$ olho não se atreve a contemplar, e nenhum pé humano jamais chegou a pisar no cume de algumas delas ${ }^{172}$.

O estudo do tema de isolamento e prisão é o objetivo fundamental do espaço cênico no texto gótico. O herói é colocado nos limites insuperáveis dos acontecimentos misteriosos e incontrolados, não possui livre-arbítrio e é submetido a uma ameaça transcendente que ele não pode evitar, independentemente da forma que ela possa vir a assumir. Em A Terrível Vingança, o feiticeiro faz de tudo para tentar escapar do seu destino, até vai ao monastério para rezar e salvar a sua alma. Mas nada pode ajudar a um grande pecador: ele é destruído, de acordo com o castigo divino terrível.

No espaço cênico de $A$ noite da véspera do dia de Ivan Kupala, o movimento dos heróis no mundo real é muito limitado, às vezes, pode-se observar o mesmo efeito de petrificação, já analisado em A Terrível Vingança. A imobilidade dos personagens é, frequentemente, relacionada a algum problema, infortúnio inesperado que sofrem. Assim ocorre quando o pai da heroína descobre o namoro da filha com o pobre rapaz: Korj, estupefato, ficou boquiaberto e agarrou a porta com a mão. O maldito beijo, ao que parecia, o ensurdecera por completo ${ }^{173}$. O protagonista também não se move quando fica sabendo de uma grande desgraça - o futuro casamento da sua namorada com o outro: Como se estivesse petrificado, sem sair do lugar, Petró escutava enquanto a criança inocente lhe murmurava as palavras de Pidorka ${ }^{174}$. A heroína, sofrendo do seu destino infeliz, diz que não vai dançar com seu noivo: me carregarão ${ }^{175}$, como se fosse um corpo morto.

Como nas obras do cânone gótico, os heróis principais estão colocados numa situação de limitação - nesse caso, a heroína é forçada a casar-se com uma pessoa que não ama, e, nessa situação, também se pode sentir a estática do seu movimento: está forçando-me a casar-me com um polaco que não amo ${ }^{176}$. O herói precisa reagir para superar as fronteiras impostas pela sociedade.

Por outro lado, a falta de movimento, em $A$ noite da véspera, está relacionada à intervenção direta das forças impuras na vida do protagonista. Depois dos acontecimentos horríveis da noite de Ivan Kupala, Petró Fica sentado no mesmo lugar e não troca palavras com ninguém ${ }^{177}$. Nesse sentido, parece coerente a observação de Mann sobre o tema da

\footnotetext{
172 GÓGOL, 1990, p. 73.

${ }^{173}$ GÓGOL, 1976, tomo I, p. 43.

${ }^{174}$ Idem, Ibidem, p. 44.

${ }^{175}$ Idem, Ibidem.

${ }^{176}$ Idem, Ibidem.

${ }^{177}$ Idem, Ibidem, p. 49.
} 
petrificação em Gógol, que, na sua opinião, “fixa um complexo estável dos sentimentos em frente de algo misterioso-estranho, [...] é pressuposta a intervenção direta no enredo dos portadores da força superior (maldosa ou bondosa), com mais frequência - em forma do fantástico $^{178,}$.

Finalmente, a estática no mundo real da novela é característica para os momentos do cume de tensão emocional das personagens. O estudioso Grékov chama esse efeito, descoberto por Gógol nessa novela e usado muitas vezes nas obras posteriores, de um "momento parado", em que Gógol cria uma imagem materializada de terror - a petrificação ${ }^{179}$. Isso acontece na cena em que os cossacos entram correndo na casa de Petró e veem, no lugar do herói, somente as cinzas: Esbugalhando os olhos e boquiabertos, não ousando mover os bigodes, os cossacos ficaram parados como se estivessem pregados ao chão. Tanto foi o pavor instigado neles por esse feitiço ${ }^{180}$.

Com a travessia do herói, junto ao vilão, ao mundo fantástico, é introduzido na obra o movimento dinâmico. Por exemplo, quando Petró tenta atingir a mágica flor de samambaia, ele observa como as centenas de mãos peludas também se estendem em direção à flor, e, por trás, algo corre de um lugar para outro ${ }^{181}$. Com a aparição da bruxa, o movimento é reforçado: Um cachorrão preto saiu correndo em seu encontro e, com um ganido, se transformou numa gata e se lançou para arrancar os seus olhos. [...] De repente, em vez de uma gata, surgiu uma velha com o rosto murcho ${ }^{182}$.

Depois de várias cenas estáticas do mundo cotidiano, a dinâmica na novela está de volta na cena de reconhecimento da bruxa por Petró e do aparecimento do fantasma da criança. Nesse momento, Petró

De repente, tremeu como se estivesse no cadafalso; o cabelo ficou em pé... e ele riu de tal modo que o terror cortou o coração de Pidorka. "Lembrei, lembrei!" - gritou ele com uma alegria assustadora e, brandindo um machado, atirou-o com toda a força na velha. O machado cravou-se por duas polegadas na porta de carvalho. A velha desapareceu e uma criança de uns sete anos, com uma camiseta branca, com a cabeça coberta, surgiu no meio da casa... O lençol caiu. "Ivás!" - gritou Pidorka e se lançou em sua

\footnotetext{
${ }_{178}^{178}$ MANN, 1988, p. 363.

179 GRÉKOV, Vladímir. "Poslédni den' Pompéi” glazami N.V. Gógolia i V.F. Odóevskovo: ot razruchéniia "idillii" k razruchéniiu kósmosa. In MANN (Org.), 2003. p. 325.

${ }^{180}$ GÓGOL, 1976, tomo I, p.51.

${ }^{181}$ Idem, Ibidem, p. 46.

${ }^{182}$ Idem, Ibidem.
} 
direção, mas o fantasma ficou ensanguentado dos pés à cabeça e iluminou a casa inteira com uma luz vermelha... ${ }^{183}$

Um barulho forte acompanha todas as ações do herói no espaço fantástico. Quando Petró tenta colher a flor, até as árvores e as plantas começam a emitir sons: Mas, aí, ouviu-se um assobio, que congelou Petró por dentro, e lhe pareceu que a grama arramalhava, as flores começavam a conversar entre si com uma voz fininha como campainhas de prata; as árvores ribombaram com uma chuva de xingamentos... ${ }^{184}$

Ao contrário, nas cenas cotidianas, é destacada a ausência de sons. Por exemplo, na cena quando Petró está sofrendo de uma doença desconhecida: Muitas vezes se levanta ferozmente do seu lugar, agita os braços, crava seus olhos em algo como se quisesse apanhálo; os lábios se movem como se quisessem pronunciar alguma palavra há muito tempo esquecida-e param imóveis... ${ }^{185}$.

O espaço-fronteira, em $A$ noite da véspera, é chamado de Medvéji Ovrag (literalmente, Barranco do Urso). É um lugar aonde o protagonista vai com o diabo para procurar tesouros. Exatamente aqui acontece a venda da alma do herói ${ }^{186}$. De acordo com a tradição do gótico, o lugar é isolado do resto do mundo, está na margem da aldeia, coberto pela densa floresta, que é difícil para penetrar. Vatsuro explica que a floresta pode ser considerada um espaço gótico, mas, para isso, ela deve receber, por assim dizer, as conotações adicionais: "A premissa para o surgimento de tais conotações é uma redução gradual do espaço. Ele se torna mais estreito e deixa menos liberdade para o movimento, e, portanto, para a fuga de um perigo ${ }^{187}$,"

Exatamente essa redução gradual do espaço pode ser observada na novela. A descrição do lugar, desde o início, parece ameaçadora e cria no leitor o sentimento de suspense: Está tão escuro que não se pode enxergar um palmo à frente do nariz. De mãos dadas, eles se enfiaram pelos pântanos lamacentos, emaranhando-se nos abrunheiros que cresciam densamente e tropeçando quase a todo passo ${ }^{188}$. É acentuado o efeito da cegueira do herói

\footnotetext{
${ }^{183}$ GÓGOL, 1976, tomo I, p. 51.

${ }^{184}$ Idem, Ibidem, p. 46.

185 Idem, Ibidem, grifo nosso.

${ }^{186} \mathrm{Na}$ sua monografia sobre o romance gótico na Rússia, Vatsuro menciona que "o próprio tema de sedução de um homem pelo diabo [...] era muito popular na literatura do final do século XVIII" (VATSURO, 2002, p. 155).

${ }^{187}$ Idem, Ibidem, p. 185.

${ }^{188}$ GÓGOL, op. cit., p. 45.
} 
que, metaforicamente falando, não vê a armadilha em que está caindo: Não se enxerga nada. As ervas daninhas negrejavam ao redor e sufocavam tudo com sua densidade ${ }^{189}$.

O isolamento do Medvéji Ovrag o separa do mundo real e obriga o leitor a compreender os acontecimentos sobrenaturais de acordo com as leis do "outro" mundo, que não segue as leis naturais. Parece mais coerente dizer que o local gótico possui seu próprio conceito de realidade. O objeto usado para uma transferência do herói de um mundo para outro é a flor de samambaia - uma peculiaridade do enredo que corresponde às crenças eslavas populares: "Na compreensão mitológica a samambaia é um espaço "ruim", é uma entrada no mundo alheio, uma janela entre o sagrado e o terrestre, através da qual os seres da esfera da morte podem aparecer na terra ${ }^{190 "}$.

Diferentemente das leis do espaço gótico, Gógol não faz dos acontecimentos no mundo fantástico um mistério. A causa da doença de Petró, na parte final da obra, é compreensível para o leitor; porém é um enigma para a heroína, que não consegue lhe ajudar:

Como se estivesse preso ao chão, fica sentado no meio da casa, os sacos com o ouro aos seus pés. Asselvajou-se, ficou peludo, feio, o tempo todo pensando na mesma coisa, se esforçando para lembrar alguma coisa, e fica com raiva e rancor por não conseguir. Muitas vezes se levanta ferozmente do seu lugar, agita os braços, crava seus olhos em algo como se quisesse apanhá-lo; os lábios se movem como se quisessem pronunciar alguma palavra há muito tempo esquecida - e param imóveis... A fúria o domina; como um demente, rói e morde suas mãos e, por despeito, arranca as madeixas do cabelo, até que, ao se aquietar, cai, como que em delírio, e depois de novo começa a lembrar, e de novo a fúria, e de novo o tormento... Que desgraça divina é esta? ${ }^{191}$

O mistério é resolvido quando, em frente a Petró, aparece o fantasma da criança Ivás que ele tinha assassinado - simbolicamente é uma hora de pagamento do herói ao diabo. Assim como na tradição do gótico, a resolução do mistério acontece no final da obra, criando uma possibilidade de desenlace - às vezes, feliz; às vezes, não.

\footnotetext{
${ }^{189}$ GÓGOL, 1976, tomo I, p.46.

190 POLIAKOVA, Angelina. Strukturoobrazúiuchtchaia rol' narodnovo kaliendariá v tsikle N.V. Gógolia “Vetcherá na khútore bliz Dikan 'ki”. Tese (Doutorado em filologia) Moskvá: Universidade estatal de Moscou de pedagogia (MPGU), 2008. pp. 37-38.

${ }^{191}$ GÓGOL, op. cit., pp. 50-51.
} 
Diferentemente da coletânea posterior Mírgorod ${ }^{192}$, em Noites, os espaços real e mágico podem entrar um no outro, formando um espaço integrado da obra. Um dos espaços aparece no outro, como as ilhas surgem do oceano - segundo Gíppius, "a invasão do demoníaco na vida humana era o tema principal de Noites ${ }^{193}$ ". Em Gógol, pode-se observar ambas as variantes da existência de um mundo no outro: o fantástico no cotidiano e viceversa.

Os espaços cotidiano e fantástico, em $A$ noite da véspera, se interpenetram. Ocorre uma introdução direta dos elementos do mundo sobrenatural no enredo "real". À primeira vista, tudo o que acontecera no Medvéji Ovrag tem uma explicação real. A heroína conta ao herói que os ciganos que passaram por sua casa haviam sequestrado Ivás ${ }^{194}$. Mas é impossível compreender de onde o herói tirou os sacos de ouro. Seguindo o raciocínio do estudioso Remo Ceserani, é possível chamar esse objeto de “mediador”, isto é, um objeto que, com sua presença no texto, dá uma espécie de testemunho de veracidade dos fatos fantásticos $\operatorname{narrados}^{195}$. Ele desempenha a sua função específica pelo fato de que atesta uma verdade equívoca, porque inexplicável, inacreditável, posto que inepta.

Dessa peculiaridade do espaço artístico gogoliano, surge o paralelismo dos mundos, com uma fronteira divisória, mas não impenetrável. É o local da obra que existe em ambos os mundos e cumpre uma função de mediador; um ponto físico "estranho", "mágico", onde ambos os espaços podem se cruzar. Assim como no enredo gótico, o protagonista e o vilão são capazes de atravessar esses pontos.

Como nas duas novelas anteriormente analisadas, em Uma noite de maio, ou uma moça afogada também existe uma contraposição entre a estática e a dinâmica de dois espaços. No cotidiano, é possível observar uma clara falta de movimento. Antes do protagonista entrar no mundo mágico, Gógol mostra uma paisagem tranquila, serena e sonolenta: $E$ a noite, pensativa, sonhadora, abraçava o céu azul, tornando tudo vago e distante ${ }^{196}$ ou ainda Toda a paisagem dorme ${ }^{197}$. Na descrição da imagem da casa abandonada, qualquer movimento é tão improvável nessa paisagem que o musgo começa a crescer no telhado da casa: Ao lado do bosque, num morro, cochilava uma velha casa de madeira com contraventos fechados; o

\footnotetext{
${ }^{192}$ Para saber mais sobre o conceito do espaço em Mirgorod, recomendamos ler SOBEL, Ruth. Time, space and genre in Gogol's 'Mirgorod'. In Essays in Poetics: The Journal of the British Neo-formalist circle, April 1981 vol. 4 №1. UK: Univ. of Keele.

${ }_{193}$ GÍPPIUS, 2009, p. 621.

${ }^{194}$ GÓGOL, 1976, tomo I, p. 48.

${ }^{195}$ CESERANI, 2006, p. 29.

${ }^{196}$ GÓGOL,op. cit., p. 54.

${ }^{197}$ Idem, Ibidem, p. 60.
} 
musgo e a erva daninha cobriam seu telhado; macieiras frondosas haviam crescido em abundância diante de suas janelas ${ }^{198}$.

Uma descrição de semelhante paisagem aparece no momento do despertar do herói que acabara de voltar do mundo mágico: A lua crescente, parada em cima da sua cabeça, indicava a meia-noite; em todo lugar reinava o silêncio; do lago, soprava um vento frio; acima dele, se encontrava a casa antiga com os contraventos fechados ${ }^{199}$.

É importante salientar o não-movimento no espaço cotidiano que, na novela, é associado especialmente a uma imagem de um bêbado cossaco Kalénik. Já foi mencionado antes o tema da dança: no mundo real, a dança não acontece. Kalénik se esforça para dançar a gopak na rua, mas não consegue - tema também usado na segunda parte de Noites, na novela Um lugar encantado.

No decorrer dos acontecimentos da novela, o leitor pode observar a infinita jornada de Kalénik. À primeira vista, parece que toda a linha do enredo dessa personagem é baseada no movimento: ele anda na rua de um lugar para outro, numa busca constante de sua casa. Mas, se olharmos com mais atenção, podemos ver que Gógol evita descrever o movimento de Kalénik, usando, para isso, uma mudança de foco narrativo: Enquanto Kalénik não atingir o fim de seu caminho, nós, sem dúvida, teremos tempo para dizer algo [...] Mas nós já contamos quase tudo o que é preciso sobre o chefe; e o bêbado Kalénik ainda não atingiu nem a metade do caminho ${ }^{200}$. Os passos cambaleantes de Kalénik encerram a novela - esse herói cumpre uma função de um "marcador" do espaço cotidiano na obra- sua menção significa que os heróis voltaram ao mundo real.

Em contraposição ao espaço cotidiano, o espaço fantástico é descrito por meio de vários tipos de movimento. Assim como em A Terrivel Vingança, nessa novela, o escritor também prefere usar os verbos no presente, nos momentos em que a ação se desenrola no espaço mágico, oposto aos verbos no passado para o espaço real. Esse instrumento estilístico não é somente típico para os momentos da ação direta no mundo mágico, mas também é para as duas narrativas inseridas, na novela, que tratam dos acontecimentos mágicos: a história da morte da pánnotchka e a história cômica da sogra do destilador. Em ambas, é possível observar o mesmo uso dos verbos no presente. Quando Levkó conta a história da moça afogada:

\footnotetext{
198 GÓGOL, 1976, tomo I, p. 57.

${ }^{199}$ Idem,Ibidem, pp. 77-78.

${ }^{200}$ Idem, Ibidem, pp. 61-62.
} 
De repente, vê uma horrivel gata preta se aproximando dela de mansinho; sua pele arde e as garras de ferro arranham o chão. Espantada, ela saltou num banco - a gata seguiu atrás dela. Atravessou num pulo para o leito - a gata também, e subitamente se atirou em seu pescoço, estrangulando-a. Arrancou-a de si com um grito, jogou-a no chão; de novo se aproxima a horrivel gata ${ }^{201}$.

Esse efeito é visível também na história da sogra: Logo que começa a noite, o finado aparece arrastando-se. Monta na chaminé da casa, o maldito, e ainda guarda uma galuchka na boca. Durante o dia, tudo está calmo; mas, logo que começa a escurecer, é só olhar no telhado, e ali está ele, já subiu na chaminé, esse filho de uma égua ${ }^{202}$.

Nas outras cenas fantásticas, Gógol introduz no texto mais verbos de movimento para torná-lo dinâmico. Pode-se ver o uso desse procedimento na cena do encontro de Levkó com as sereias, no momento do jogo de corvo: A multidão se esticou numa fileira e corria de um lado ao outro, fugindo dos ataques do inimigo rapinador ${ }^{203}$, ou também na descrição dos movimentos da bruxa: Perseguia a fileira com velocidade e audácia, e se atirava para todos os lados, tentando capturar sua vítima ${ }^{204}$.

As cenas cotidianas são silenciosas, tanto na fala das personagens como na paisagem da obra. Levkó se aproxima da casa da sua namorada com os movimentos quietos, cuidadosos: Finalmente, parou silencioso diante da porta de uma casa cercada por cerejeiras não muito altas ${ }^{205}$. Ele toca sua bandurra não muito alto: Com isso, ele se virou, enterrou o gorro na cabeça e, indignado, afastou-se da janela, dedilhando fracamente as cordas da bandurra $^{206}$.

Os diálogos das personagens, no mundo real, também são dirigidos em voz baixa, tão baixa que, às vezes, eles não conseguem se ouvir. Daí, aparecem, na novela, os temas de surdez e desentendimento no mundo real. Ganna conversa com Levkó : - Como você é impaciente, - disse-lhe à meia voz. - Já se zangou! ${ }^{207}$ A conversa de Ganna com o chefe da aldeia é descrita como um murmúrio baixo:

\footnotetext{
${ }^{201}$ GÓGOL, 1976, tomo I, p. 58.

${ }^{202}$ Idem, Ibidem.

${ }^{203}$ Idem,Ibidem, p. 77.

${ }^{204}$ Idem, Ibidem.

${ }^{205}$ Idem, Ibidem, p. 54.

${ }^{206}$ Idem, Ibidem.

${ }^{207}$ Idem, Ibidem, p. 55.
} 
- Levkó? Levkó ainda é um fedelho! - dizia o homem alto a meia voz rouca. [...] - Gostaria de saber quem é esse patife que se vangloria de arrancar meu topete! - pronunciou Levkó em voz baixa e esticou o pescoço, esforçando-se para não perder nenhuma palavra. Mas o desconhecido continuava a falar em voz tão baixa, que não se podia distinguir nada ${ }^{208}$.

A paisagem, assim como nos romances góticos sentimentais, é melancólica e silenciosa. Já no início da novela, Ganna descreve o lago como calmo e quieto: Como a água está ondulando sem ruído, tal qual uma criança em seu berço! ${ }^{209}$. No segundo capítulo, o narrador dá uma descrição da majestosa noite ucraniana, reforçando uma impressão do sono profundo da natureza: São quietos e tranquilos esses lagos [...].Virgens brenhas de azereiras e cerejeiras estenderam com temor suas raizes no frio das águas e, de vez em quando, murmuram com suas folhas ${ }^{210}$.

Antes de Levkó adormecer, a natureza é ainda mais silenciosa: Tudo estava silencioso. Do matagal, ouviam-se somente os trinos de um rouxinol. Um sono invencível começou a pregar os olhos de Levkó; o corpo, cansado, estava pronto para cair na modorra e se entorpecer; a cabeça inclinada... ${ }^{211}$. Essa cena, na obra, cumpre as duas funções. Em primeiro lugar, ela prepara o contraste entre o mundo mágico, cheio de ruídos, e o mundo real. Em segundo lugar, ela faz o leitor acreditar que tudo que está acontecendo é verdade. Gógol usa, nessa novela, o sonho para ajudar o herói a entrar no espaço fantástico - um procedimento artístico muito divulgado desde o início do século $\mathrm{XIX}^{212}$.

Diferentemente do espaço cotidiano, durante o encontro de Levkó com a pánnotchka, a paisagem é descrita através de vários tipos de som: Canções de rouxinóis ecoavam umas nas outras de um modo vibrante e sonoro, e, quando pareciam morrer na ânsia e volúpia, ouvia-se o farfalhar e o cricrido dos grilos ou o estalido de uma ave do pântano, que batia com seu bico escorregadio no espelho amplo das águas ${ }^{213}$. O aparecimento da bruxa é marcado por um grito:

De repente, ressoou um grito: o corvo se atirou sobre uma das moças da fileira, agarrou-a, e pareceu a Levkó que suas garras se mostraram e, em seu rosto, fulgurou uma alegria maldosa.

\footnotetext{
${ }^{208}$ GÓGOL, 1976, tomo I, p. 63.

${ }^{209}$ Idem, Ibidem, p. 57.

${ }^{210}$ Idem,Ibidem,p. 60.

${ }^{211}$ Idem, Ibidem.

${ }^{212}$ MANN, 1988, p. 94.

${ }^{213}$ GÓGOL, op. cit., p. 75.
} 
- Bruxa! - disse, de súbito apontou para ela, e se voltou para a casa. A pánnotchka deu uma risada e as moças, com um grito, levaram consigo aquela que representava o corvo ${ }^{214}$.

A fronteira entre os dois mundos é muito visível em Uma noite de maio. Logo que a personagem a ultrapassa, ela se fecha como uma armadilha: o herói se encontra num lugar isolado e não consegue sair de lá, se torna um prisioneiro do local, sofre ameaças - inclusive da personagem bondosa como pánnotchka, que precisa dos vivos para adivinhar quem é a bruxa entre as sereias: E se ela encontrar alguma pessoa viva, imediatamente, força-a a adivinhar, do contrário, ameaça afogá-la na água ${ }^{215}$.

A fronteira é "um lugar terrível" - uma casa abandonada, ao lado de um sombrio lago. Conforme nos informa Vatsuro, no gótico, “'O lugar terrível' é metafórico e cronotópico, exatamente com ele está associada uma lenda supersticiosa que cria um ambiente de um mistério. Uma peculiaridade muito importante dessa lenda é que ela é "justa", isto é, de um modo mistificado descreve os acontecimentos completamente reais, que constituem a préhistória da narrativa ${ }^{216 \%}$.

Na novela gogoliana, o mistério cerca a casa abandonada. Ela é introduzida já no primeiro capítulo, e, assim, o leitor está sendo preparado para os acontecimentos estranhos: Ao lado do bosque, num morro, cochilava uma velha casa de madeira com contraventos fechados; o musgo e a erva daninha cobriam seu telhado; macieiras frondosas haviam crescido em abundância diante de suas janelas ${ }^{217}$. Gógol usa a "ativação" desse espaço gótico: a sua heroína, Ganna, pergunta a Levkó sobre uma história que acontecera na velha casa: há muito, muito tempo, quando eu ainda era pequena e morava na casa de minha mãe, contavam algo assustador sobre aquela casa ${ }^{218}$. Nesse momento, o fantástico começa a entrar no enredo de várias formas. $\mathrm{O}$ descobrimento do mistério acerca da casa e o restabelecimento da justiça é a tarefa principal do herói; sem isso, ele não conseguirá a felicidade na sua própria vida, no mundo real.

A casa, como uma fronteira, possui todas as conotações de um espaço gótico. É abandonada e isolada do resto da aldeia - está situada num morro, e é apresentada em contraste com as casinhas iluminadas dos cossacos. É ainda salientado o caráter fechado do espaço: com contraventos fechados ${ }^{219}$.

\footnotetext{
${ }^{214}$ GÓGOL, 1976, tomo I, p. 77.

${ }^{215}$ Idem, Ibidem, p.58.

${ }^{216}$ VATSURO, 2002, p. 187.

${ }^{217}$ GÓGOL, op.cit., p. 57.

${ }^{218}$ Idem, Ibidem.

${ }^{219}$ Idem, Ibidem, p. 57.
} 
Segundo Lótman, na novela, existem duas casas nos espaços real e mágico: “[...] simplesmente, há perto da aldeia um lago real com uma casa velha, mas, nesse mesmo lugar, está situado o outro lago, com outra casa, via de regra, inacessíveis para as pessoas (pode-se

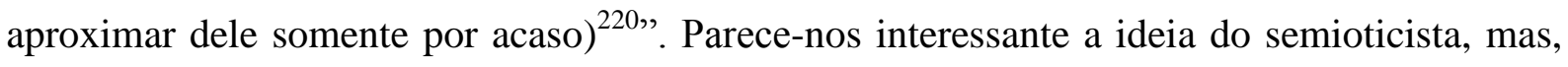
em nossa opinião, a casa serve como um meio de uma transição dos heróis entre os espaços, e, por isso, deve ter a dupla existência que varia de acordo com as leis do mundo onde está situada. Pode-se dizer que a casa possui uma imagem distorcida no outro mundo.

No mundo real, o lago e a casa são descritos por Gógol como velhos, sólidos e parados no seu movimento, por tanto tempo, que o mofo e o musgo começaram a penetrá-los. A casa no espaço cotidiano, assim como toda a natureza nos seus redores, está dormindo. O lago é comparado a um velho homem, introduzindo na obra, pela primeira vez, o tema da reclusão e do cativeiro: Como um fraco ancião, ele agarra com seus abraços frios o céu longínquo, escuro, cobrindo de beijos gélidos as estrelas ardentes ${ }^{221}$. No mundo mágico, a casa e o lago se transformam de tal maneira que o protagonista não os reconhece. O edifício é descrito com luzes e cores brilhantes: No lugar dos contraventos soturnos, as janelas de vidro e as portas resplandeciam alegremente. Através das vidraças limpas, cintilava algo dourado ${ }^{222}$.

A dupla existência é possível por meio de um reflexo nas águas do lago - uma das imagens preferidas em toda obra de Gógol. Karandachova nota que "na obra gogoliana é constante uma ideia da paisagem refletida (invertida) como uma imagem de vastidão ${ }^{223}$ ". É interessante notar que o conceito do duplo já foi desenvolvido na antiga mitologia grega, espalhando-se, posteriormente, por toda a literatura europeia ${ }^{224}$. Segundo o pensamento mitológico dos gregos, "o duplo é uma realidade exterior ao sujeito, mas que, em sua própria aparência, opõe-se pelo seu caráter insólito aos objetos familiares, ao cenário comum da vida. Move-se em dois planos ao mesmo tempo contrastados: no momento em que se mostra presente, revela-se como não pertencendo a este mundo, mas a um mundo inacessível ${ }^{225}$ ". Em nossa opinião, é possível observar algo parecido no conceito do espaço físico, desenvolvido em Noites.

\footnotetext{
${ }^{220}$ LÓTMAN, 1988, p. 262.

${ }^{221}$ GÓGOL, 1976, tomo I, p. 57.

${ }^{222}$ Idem, Ibidem, p. 75.

${ }^{223}$ KARANDACHOVA, 1999,p. 104.

${ }^{224}$ Para saber mais sobre a influência da literatura grega em Gógol, ver CHAUNCEY, Finch E. Classical influence on N.V. Gogol. In The Classical Journal, Vol. 48, №8 (May, 1953). pp. 291-296.

225 VERNANT, Jean-Pierre.Mito e pensamento entre os gregos. Estudos de psicologia histórica. Trad. Haiganuch Sarian. Rio de Janeiro: Paz e Terra, 1990. p. 309.
} 
Uma noite de maio é, possivelmente, uma das novelas gogolianas que, em um grau maior que as outras, possui o paralelismo dos espaços. O espaço fantástico constantemente aparece no cotidiano. Isso é lógico não somente para a poética do escritor, mas para toda a prosa russa do primeiro quartel do século XIX: "A motivação paralela, ou dupla dos fenômenos sobrenaturais, representada de um jeito mais marcante na fantástica de Hoffmann, determinou a rede inteira dos recursos artísticos da assim chamada fantástica mascarada ${ }^{226 "}$.

Por exemplo, o fantástico penetra no enredo "real" em forma de confusão festiva do assim chamado "mundo às avessas". O caráter carnavalesco de toda a coletânea já foi indicado por Mikhail Bakhtin em seu estudo sobre o assunto: nas novelas, é mostrado um caos descontrolado, uma perturbação peculiar da ordem habitual do mundo ${ }^{227}$. Em relação ao romance de terror, a inconstância carnavalesca e sua capacidade de gerar desordem podem ser compreendidas como uma modificação da instabilidade e complicação do enredo gótico. Segundo Zalómkina, se o festivo pode ser entendido como alegre e não cotidiano, o gótico é horrível e não cotidiano ${ }^{228}$. Cabe aqui lembrar que o alegre e feliz carnaval tem seu análogo "escuro" - a mascarada, que traz associações com as forças sinistras, misteriosas e macabras.

Em Uma noite de maio, o chefe da aldeia e seus companheiros são mortalmente assustados pelas "transformações demoníacas" do diabo num casaco de pele virado ao avesso. Ele se transforma duas vezes na cunhada do cabeça e uma, no bêbado Kalénik. Isso não é exatamente fantástico, mas é mágico na percepção dos heróis. Uma cena parecida é representada em A Feira de Sorótchintsy, em que a manga da misteriosa camisa vermelha aparece em muitos lugares da feira sem qualquer explicação. Tal desenrolar dos eventos seria pouco provável num enredo realista. Essas transformações são usadas por Gógol como mais um meio de introduzir o sobrenatural no enredo cotidiano. No momento em que Levkó e os seus amigos fazem travessuras na aldeia, o cabeça e o escrivão começam a mencionar o diabo no diálogo: Que força impura te arrastou para cá, minha cara, neste buraco? ${ }^{229}$ e também Não, aqui o Satanás se envolveu a sério ${ }^{230}$.

Ocorre também, na novela, uma introdução direta dos elementos do mundo sobrenatural no enredo "real". A carta do comissário que Levkó traz do mundo alheio é um elemento fantástico introduzido no cotidiano. Sua presença serve como uma espécie de

\footnotetext{
${ }^{226}$ KAPITÁNOVA, L. A., KORÓVIN, V.I. et. al. Proza vèpókhu romantizma. In KORÓVIN, V.I. (org.). Istóriia rússkoi literatury XIX veka: v 3 tchastiákh. Parte 2. Moskvá: Vládos, 2005. p. 89.

${ }^{227}$ BAKHTIN, M.M. Rablé i Gógol'. In Tvórtchestvo Fransuá Rablé e naródnaia ku'ltura srednevekóv'ia i Renessansa. Moskvá: Khudójestvennaia literatura, 1965.

${ }^{228}$ ZALÓMKINA, 2006, p. 170.

${ }^{229}$ GÓGOL, 1976, tomo I, p. 73.

${ }^{230}$ Idem, Ibidem.
} 
testemunho de veracidade dos fatos fantásticos narrados: a folha, escrita pelo comissário, torna inexoravelmente verdadeira (e não mais explicável como sonho, pesadelo, projeção subjetiva do protagonista) a presença da pánnotchka e da bruxa na casa abandonada.

O paralelismo dos espaços em Uma noite de maio é percebido também no nível do enredo - através da repetição dos destinos dos heróis. Segundo Gontcharov, a história de Ganna tem uma ligação óbvia com a pánnotchka. Em primeiro lugar, Levkó encontra ambas as mulheres através de uma janela, atraindo-lhes com uma bela canção. As duas moças são pálidas e associadas à água. A casa de Ganna se situa à beira do velho lago. A casa abandonada do sótnik, provavelmente, está do outro lado do lago, reforçando, assim, uma ligação entre as moças ${ }^{231}$. O texto inteiro da novela é composto pelo sistema de sósias e duplicação das situações; a única diferença consiste no caráter cômico ou trágico dos acontecimentos $^{232}$. Por exemplo, o conflito cômico entre Levkó e seu pai no mundo real é repetido tragicamente no conflito entre a pánnotchka e sua madrasta. A vitória contra o mal no mundo alheio significa também o final feliz no mundo real: "o mundo "alheio" como que permite o amor e o casamento, neutralizando os obstáculos neste mundo ${ }^{233}$ ".

Em A Carta Perdida, qualquer movimento do herói no espaço cotidiano é estático. Isso, provavelmente, pode ser explicado por meio da conexão desse texto com o conto maravilhoso. Segundo Propp, “o espaço desempenha no conto um papel duplo. Por um lado, ele existe e é um elemento de composição absolutamente indispensável. Por outro lado, é como se não existisse. Todo o desenrolar da ação ocorre durante as paradas e estas são elaboradas em detalhes ${ }^{234}$ ". Assim acontece também na novela em questão: as cenas do mundo cotidiano acontecem nos momentos das paradas do herói, o próprio movimento não é descrito: No outro dia, o galo ainda não cantara pela quarta vez, e o vovô já estava em Konotop $^{235}$. Na viagem do cossaco, Gógol simplesmente apresenta as novas personagens sem mostrar qualquer dinâmica: Mal conseguiu dar vinte passos - ao seu encontro surgiu um zaporójetz $^{236}$.

A estática geral do espaço cotidiano é destacada com o tema de sonho. Na feira em Konotop, onde o herói encontra o zaporójetz, todas as pessoas estão dormindo:

\footnotetext{
${ }^{231}$ GONTCHAROV, S.A. Son - duchá, liubov' - sem 'iá, mujskóe - jénskoe v ránnem tvórtchestve Gógolia. In (org.) Gógolevski sbornik. Sankt-Peterburg: Obrazovánie, 1993. pp. 4 - 41.

${ }^{232}$ Idem, Ibidem, p. 28.

${ }^{233}$ Idem, Ibidem, p. 5.

${ }^{234}$ PROPP, 1997, p. 44

${ }^{235}$ GÓGOL, 2014, p. 97.

${ }^{236}$ Idem, Ibidem.
} 
Mas, como era cedo, todos ainda cochilavam, estendidos no chão. Ao lado de uma vaca, estava deitado um rapaz festeiro de nariz avermelhado, como um pisco-chilheiro; nas proximidades, sentada, uma vendedora roncava, com pederneiras, anil, chumbinho e rosquinhas; debaixo duma telega um cigano estava deitado; numa carroça - um tchumak; e bem no meio da estrada esticava as pernas um barbudo moscal, com cintos e luvas... ${ }^{237}$

O movimento começa a crescer no momento em que o cossaco, cometendo uma ação mágica, cruza a fronteira entre os dois mundos: Logo que jogou o dinheiro, tudo se embaralhou na frente dele, a terra tremeu e, como que - ele já não sabia mais contar achou-se quase no próprio inferno ${ }^{238}$.

No mundo mágico, destacam-se as cenas de dança coletiva - como já foi mencionado, na obra gogoliana, associada às forças infernais. As bruxas e os diabos, na novela, como os ébrios, estavam envolvidos em algum baile infernal. [...] $O$ avô, apesar de todo o medo, foi atacado pelo riso quando viu como os diabos, com seus focinhos, de pernas alemãs, virando os rabos, estavam cortejando as bruxas que nem os rapazes perto das moças, e os músicos batiam as suas bochechas com os punhos fechados ${ }^{239}$.

No final da novela, com a dança, a magia penetra o mundo real: ao voltar a sua casa, o protagonista observa sua esposa se movendo sem vontade própria: a baba estava sentada, dormindo em frente ao pente, segurava na mão o fuso e, sonolenta, saltava no banco ${ }^{240}$. De acordo com as crenças eslavas, os movimentos involuntários, frequentemente, são provocados pela força impura. Conforme os estudos folclóricos de Aleksandr Afanás'ev, "as febres chegam voando para a terra, apoderam as pessoas, começam a sacudi-las, enfraquecem suas articulações e fazem doer os ossos ${ }^{241}$ ".

Como nas outras novelas aqui analisadas, o som é um marcador de um espaço mágico em A Carta Perdida. Antes do começo dos eventos fantásticos, Gógol descreve um ambiente silencioso, tão silencioso que parecia que nenhuma mosca voava ${ }^{242}$. Mas, quando o cossaco entra na floresta mágica, ouve-se um som tão alto que sentiu um zumbido na cabeça, como se fosse de cem martelos batendo ${ }^{243}$.

O inferno também é descrito com muitos barulhos diferentes: os músicos batiam as suas bochechas com os punhos fechados como em pandeiros e com os narizes sopravam feito

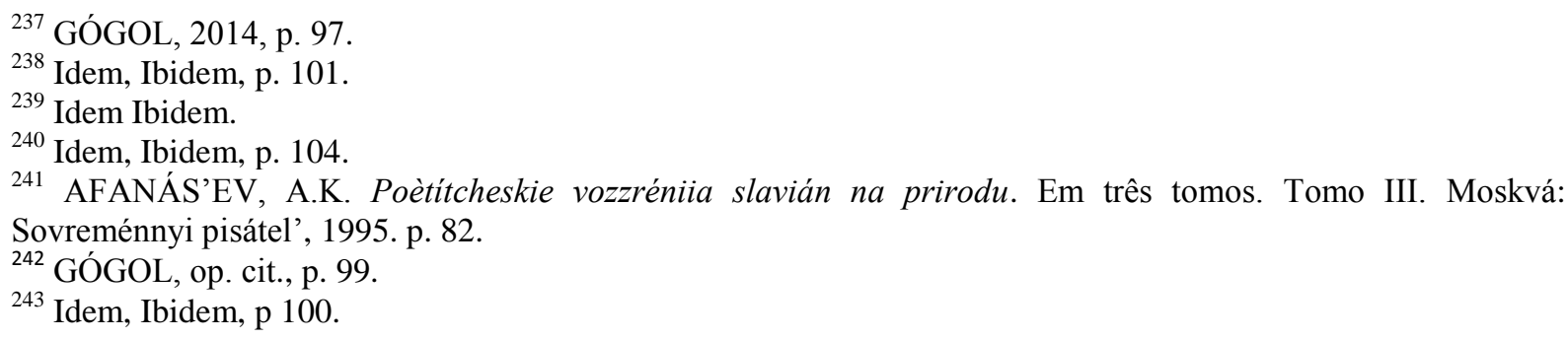


trompas $^{244}$; todos os monstros arreganharam os dentes e soltaram tanta gargalhada que a alma do avô congelou ${ }^{245}$.

O espaço-fronteira, em A Carta Perdida, é a floresta encantada, assim como em outros textos góticos. Mas, para ser um espaço gótico, a floresta, no enredo, deve se situar num lugar recluso, isolado dos outros. Na novela, para atingir o seu objetivo, o herói supera vários obstáculos, descritos nas palavras do taberneiro - uma pessoa misteriosa que possui um conhecimento de como penetrar o outro mundo:

Perto da taberna tem uma curva à direita em direção à floresta. [...] Vai ter muito ruido na floresta, mas não vá na direção de onde vem o ruído; e surgirá na sua frente um atalho estreito. Passando uma árvore queimada, siga pelo atalho, continue andando... $O$ abrunheiro vai te arranhar, a densa aveleira irá obstruir o seu caminho - mas você deve continuar; e quando chegar a um pequeno rio, só então poderá parar ${ }^{246}$.

Como é possível observar nesse pequeno trecho, o protagonista atravessa a floresta e o rio $^{247}$, também cruzado por uma pequena ponte. É pertinente também lembrar que, ao entrar em contato com os diabos, o autor menciona os temas de fogo e ouro, típicos do conceito de fronteira no folclore russo. Os diabos esperam o herói perto de uma chama, na qual o cossaco joga todo o dinheiro que tem, e, depois disso, cai diretamente no inferno.

Foi também notado que é importante a indicação da cidade de Konotop, onde o cossaco começa sua jornada ao inferno ${ }^{248}$. Na realidade, Konotop não estava no caminho para Petersburgo. Mas a cidade recebeu seu nome porque, em seus arredores, muitos viajantes perderam seus cavalos nos pântanos lamacentos ${ }^{249}$. Então, pode-se ver Konotop como outra fronteira entre os mundos, porque o herói, na sua viagem ao inferno, perdera o cavalo.

A ação principal do enredo da novela se desenrola no espaço mágico. $\mathrm{O}$ cossaco, ao chegar ao inferno, descobre que não tem saída a não ser que passe por uma prova. Nessa novela, a prova é dada de uma maneira cômica - o herói precisa vencer as bruxas num jogo de cartas. Mas mesmo assim, o cossaco não tem direito de sair do espaço mágico, e até corre o

\footnotetext{
${ }^{244}$ GÓGOL, 2014, p.101.

${ }^{245}$ Idem, Ibidem, p. 102.

${ }^{246}$ Idem, Ibidem, p. 100.

${ }^{247}$ Conforme o pesquisador Lévtchenko, "o rio no modelo antigo do mundo é considerado um eixo que une os mundos alto, médio e baixo. O rio é uma fronteira entre os mundos 'próprio' e 'alheio"'. LÉVTCHENKO, O.A. Prostránstvenno-vremennye otnochéniia v rússkoi romantítcheskoi ballade 20-30-h godov XIX veka. In Rússkii romantizm: prostranstvo e vrémia. Dáugavpils: Izdátel'stvo Daugavpíllskovo pedagogítcheskovo universiteta, 1991. p. 33.

${ }^{248}$ DMÍTRIEVA, 2011, p. 107.

${ }^{249}$ Kon' em russo significa "cavalo" e "topit" - "afogar".
} 
risco de perder sua vida (não vai ver mais não só o chapéu, mas, talvez, até veja o seu fim ${ }^{250}$ ). Os acontecimentos no mundo irreal têm suas consequências paralelas no mundo real: o cossaco consegue devolver a carta à tzarina no inferno, mas perde o cavalo. Acha-se na mesma situação na sua volta a casa, de onde recomeça sua viagem.

Como se pode observar, as quatro novelas aqui analisadas seguem o mesmo padrão de formação do espaço: mundo real - fronteira - mundo fantástico. Os dois mundos entram em um sistema de oposições: estática/dinâmica, silêncio/som, morto/vivo. A fronteira, em Gógol, além de espaço típico para um romance gótico, como um castelo, assume outras formas, como a casa abandonada, a floresta, Medvéji Ovrag. O paralelismo de dois mundos é sublinhado por meio dos vários procedimentos artísticos, principalmente com a introdução dos elementos fantásticos no enredo real. As ações dos heróis, no mundo mágico, geram consequências graves no mundo cotidiano, às vezes, levando as personagens até a morte. Somente o herói que consegue restabelecer a justiça e lutar com as forças do mal tem direito de voltar à realidade, merece a felicidade no mundo de Dikanka, é digno de uma história heroica ou engraçada na mesa entre os convivas de Rúdyi Pankó.

${ }^{250}$ GÓGOL, 2014, p. 102. 


\section{O sistema dos narradores}

Se espalharam e ressoaram como o mar em tempestade os rumores e murmúrios no meio do povo ${ }^{251}$.

(Gógol, N. V. A Terrivel Vingança, 1832).

A estrutura narrativa do texto é um aspecto importante para a compreensão da poética do gótico. Frequentemente apresentado como uma narrativa de outra pessoa, o texto gótico é parecido com uma cadeia de cenas cativantes, tais como aparecimentos inesperados dos fenômenos sobrenaturais, perda de trajeto pelo herói, descobrimento dos objetos misteriosos, encontros com outras pessoas etc. Esses "microenredos" atrasam a ação geral da obra e geram um ambiente de espera intensa. Ao mesmo tempo, eles preenchem as lacunas do enredo principal, esclarecem os momentos obscuros.

A novela gótica nos lembra um vitral da igreja católica: feito de muitos pedaços pequenos, ele gera, no espectador, uma impressão íntegra somente se todos os seus elementos são descobertos e analisados. A narrativa é construída por meio das histórias dos testemunhos, rumores, lendas, canções, profecias, cartas, manuscritos antigos, anotações nos diários, até os retratos familiares que podem ser vistos como uma história objetivada (assim, por exemplo, acontece na novela de Gógol, $O$ retrato, de $1835^{252}$ ). Geralmente, no texto gótico, "a propensão para o discurso múltiplo é muito desenvolvida, é dialógico por causa de sua indeterminação ou sua estrutura aberta ${ }^{253}$ ". Com sua verossimilhança peculiar, heteroglossia e caráter fragmentário das histórias, a obra gótica parece um mundo independente, cujo objetivo principal é revelar os aspectos escondidos da realidade habitual. O estudioso Michael Gamer salienta que os leitores estão frequentemente

[...] duas ou três vezes afastados dos acontecimentos do romance. [...] Essa experiência de leitura, por sua vez, nos conduz a examinar nossos próprios processos de interpretação, visto que, como os leitores, nós estamos

\footnotetext{
${ }^{251}$ GÓGOL, 1990, p. 45.

${ }^{252}$ Vatsuro, em sua monografia sobre o romance gótico na Rússia, diz que "O retrato no romance gótico, via de regra, não é um objeto, mas um dos motivos que organiza o enredo" (VATSURO, 2002, p. 188).

${ }^{253}$ HOWARD, Jaqueline. Reading Gothic fiction: A Bakhtinian Approach. Oxford: Clarendon Press, 1994. p. 16.
} 
confrontados por desafios psicológicos similares àqueles enfrentados pelas personagens ${ }^{254}$.

Como mencionamos na introdução, na obra de Gógol, existe um sistema inteiro de narradores, que cumprem, nas novelas, pelo menos cinco funções importantes para a poética do gótico: criação de uma distância temporal, demonstração de um processo de criação de uma lenda, introdução dos elementos fantásticos no enredo, objetivação e desorientação do leitor.

Em primeiro lugar, a função das narrativas inseridas é criar uma distância temporal entre o leitor e os heróis. Como alguns narradores são testemunhas dos acontecimentos distantes, ou até tinham ouvido os relatos dessas testemunhas, sua introdução, no texto, ajuda a penetrar o passado, reconstruir os acontecimentos "assim como eles eram". Por muito tempo, os pesquisadores da obra gogoliana não perceberam como o escritor é minucioso ao mencionar os acontecimentos históricos concretos. Gukóvski, o estudioso soviético conhecido por sua pesquisa detalhada do realismo em Gógol, falava somente em "ambiente históricosocial $^{255 "}$ das novelas, mas, se observarmos os textos com mais atenção, os narradores de todas as novelas tratam de alguns eventos ou detalhes históricos que deixam compreender melhor as fronteiras temporárias de cada história.

Assim, os eventos de A Terrivel Vingança acontecem entre os anos 1620 e 1639. Para provar isso, o narrador indica que pan Danilo tinha participado na marcha de Piótr Sagaidátchnyi ${ }^{256}$ contra os turcos em 1620. A batalha à beira do lago Sivach (Salióni) é o episódio central dessa marcha. São, também, mencionadas a batalha no campo Pereschliái

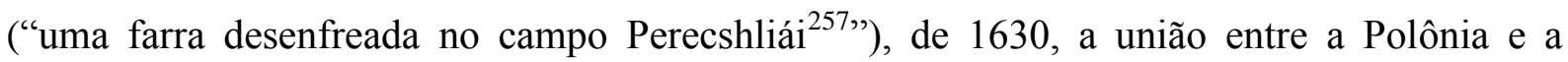
Turquia em 1634 - 1639, e vários outros episódios históricos. A história do bandurrista sobre o conflito entre Ivan e Petró pertence ao passado ainda mais distante - ao reino de Estêvão Báthory $(1575-1586)^{258}$.

Os eventos de A Noite na véspera no dia de Ivan Kupala compreendem o período entre o final do século XVI e o início do século XVII ${ }^{259}$. Pode-se entender isso se

\footnotetext{
${ }^{254}$ GAMER, Michael. Gothic fictions and Romantic writing in Britain. In HOGLE, 2002, p. 102.

255 GUKÓVSKI, G. A. Realizm Gógolia. Moskvá-Leningrad: Gosudárstvennoe izdátel’stvo khudójesvennoi literatury, 1959. p. 113.

${ }^{256}$ Sagaidátchnyi (Conachévitch) Piótr - hetman ucraniano que em 1616-1621 comandava as marchas dos zaporójetz contra os turcos.

${ }^{257}$ GÓGOL, 1990, p. 43.

${ }^{258}$ DMÍTRIEVA, 2011, pp. 101-102.

${ }^{259}$ Idem, Ibidem.
} 
observarmos, com atenção, os costumes dos camponeses no casamento e as descrições do vestuário, típicas para essa época, na narrativa da tia do diácono:

A tia do meu avô, às vezes, contava - era uma maravilha só! As moças, com cabeça enfeitada de fitas amarelas, azuis e rosas, em cima das quais se atava um cadarço dourado, de camisetas finas bordadas em todas as costuras com um fio de seda vermelha e adornadas com pequenas florzinhas de prata, de botas de marroquim com altas ferraduras, dançavam a górlitsa graciosamente, como as pavoas, ou ruidosamente como um tufão. As recémcasadas, endireitando-se com ar de importância, pavoneavam-se uma a uma e, em ritmo, batiam a gopak, com barquinhos na cabeça, cujas copas foram todas feitas de brocado de fios dourados, com um pequeno recorte na nuca, de onde emergia uma touca dourada, com dois corninhos de smuchka preta mais fina; de kontuzs azuis, feitos da melhor seda, com as paletas vermelhas. Os rapazes, de altos chapéus de cossaco, de camisolões finos de feltro, apertados com cintos bordados de prata, com os cachimbos na boca, desfaziam-se em rapapés diante delas e tagarelavam ${ }^{260}$.

Em Uma noite de maio, um dos heróis, o cabeça da aldeia, conta os detalhes do outro evento histórico - a viagem da tzarina Catarina para Criméia em 1787: Mas nos velhos tempos, quando eu guiava a tzarina pela estrada de Pereiaslav e o falecido Bezboródko ainda... ${ }^{261}$. Então, pode-se admitir que a ação principal da novela se desenrola nos anos 1790 , talvez dez ou quinze anos mais tarde, porque o narrador diz que é de se duvidar que alguém possa lembrar esse tempo em toda a aldeia ${ }^{262}$.

O tempo histórico de A Carta Perdida pertence ao período entre 1750 e 1764 . O narrador explica que o herói recebe uma ordem do próprio hetman para levar uma carta à tzarina; assim podemos concluir que era a tzarina Isabel (1741 - 1761) ou Catarina II (1762 1796), porque o cossaco começa a sua viagem de Baturin - a residência de hetman até $1764^{263}$.

Todos os intervalos temporais, nas novelas, são distantes da época atual ao autor - a primeira metade do século XIX. Na narrativa gótica, os relatos do passado são "encapsulados" no enredo maior que, dessa maneira, pode se estender por muito tempo, às vezes, até

\footnotetext{
${ }^{260}$ GÓGOL, 1976, tomo I, pp. 48-49.

${ }^{261}$ Idem, Ibidem, p. 66.

${ }^{262}$ Idem, Ibidem, p. 62.

${ }^{263}$ DMÍTRIEVA, 2011, pp. 101-102.
} 
incorporar vários séculos, como acontece em A Terrível Vingança. Simpson observa que, nos textos típicos desse gênero,

[...] a história é subdividida nos relatos diferentes que podem ser vistos como os pedaços independentes ou parte de um todo. Os vários fios dos relatos separados são bem unidos. [...] Todos os narradores lançam alguma luz sobre o mesmo acontecimento, constantemente expandindo nossas percepções do seu mistério e horror. Essa narrativa deslocável adiciona as qualidades necessárias góticas de suspense e subjetividade à receita volátil ${ }^{264}$.

Nesse sentido, o objetivo dos narradores diferentes é também mostrar o processo da criação de uma lenda. Os moradores da aldeia lembram os ecos distantes dos acontecimentos e os interpretam do seu modo, vendo o passado como uma causa do presente. Ekaterina Dmítrieva, comparando os narradores nos romances históricos de Walter Scott com os das novelas ucranianas de Gógol, destaca que o leitor "enfrenta o passado distante exatamente graças ao sistema dos prefácios e dos narradores fictícios, quando os acontecimentos são apresentados como a verdade verbal, transferida boca-a-boca, e, portanto, a verdade não é absoluta, mas relativa ${ }^{265 "}$. O escritor transfere a responsabilidade pela veracidade aos outros ao diácono Fomá Grigórievitch e aos seus amigos da granja.

Ao mesmo tempo, deve-se tomar em conta que o autor empreende um esforço para fazer o leitor acreditar no caráter verossímil das lendas. Por exemplo, ele menciona que o avô de Fomá Grigórievitch nunca mentira em toda sua vida, e o que ele, às vezes, dizia era exatamente o que tinha acontecido ${ }^{266}$. O próprio editor Rúdyi Pankó, dando as características aos narradores, diz que essas pessoas não são uma gente simples, não são alguns mujiques da granja $^{267}$ - são pessoas educadas e cultas.

O distanciamento temporal também permite ao autor, através dos seus narradores, a introduzir os elementos fantásticos no enredo. O passado, frequentemente, é visto não como um fundo histórico (embora, como já vimos, em Gógol, as fronteiras do tempo sejam bem delineadas para cada novela), mas como o mundo especial, com as suas próprias peculiaridades e leis de existência. Se a magia é impossível no presente, ela faz parte natural do mundo no passado, porque não há como conferir os acontecimentos; o leitor pode só confiar ou não confiar no narrador. Iúri Mann notou que, em Noites, todos os fenômenos fantásticos são realmente visíveis para os heróis somente nas narrativas dos tempos distantes,

\footnotetext{
${ }^{264}$ SIMPSON, 1986, p. 33.

${ }^{265}$ DMÍTRIEVA, 2011, p. 84.

${ }^{266}$ GÓGOL, 1976, tomo I, p. 40.

${ }^{267}$ Idem, Ibidem, p. 8.
} 
enquanto, no presente ou no passado próximo, todo o mágico acontece durante o sonho ou por causa dos efeitos de embriaguez ${ }^{268}$. Assim, em $A$ Terrível Vingança, A noite da véspera de Ivan Kupala e A Carta Perdida, que pertencem ao passado distante, os poderes sobrenaturais interferem diretamente na trama: existem personagens como o diabo e a bruxa, as pessoas fazem acordo com os poderes superiores.

Em Uma noite de maio, que acontece no final do século XVIII - o tempo quase contemporâneo a Gógol, o fantástico é deslocado para a pré-história e para o sonho do protagonista. Os eventos fantásticos aqui pertencem a um tempo distante e são relatados pelas personagens em uma forma de velhas lendas: sobre a pánnotchka, narrada pelo protagonista, e sobre a sogra, narrada pelo destilador. Ambas as narrativas, de certo modo, são "ghost stories". Mas a primeira narra sobre os acontecimentos de um modo trágico, e a outra, de um modo cômico.

Como mencionamos brevemente, no capítulo anterior, o narrador gótico ativa o enredo fantástico. Contando uma lenda antiga, ele torna possível o surgimento dos fenômenos sobrenaturais no texto. A estrutura narrativa da novela gogoliana pode ser entendida melhor por meio do seguinte esquema:

Esquema 2. Estrutura narrativa típica em Noites.

\begin{tabular}{|c|c|c|c|}
\hline $\begin{array}{l}\text { Relato de algum } \\
\text { acontecimento } \\
\text { estranho no } \\
\text { passado }\end{array}$ & $\begin{array}{l}\text { O herói encontra } \\
\text { um fenômeno } \\
\text { descrito no mundo } \\
\text { mágico }\end{array}$ & $\begin{array}{l}\text { Surgem dúvidas e } \\
\text { rumores sobre o } \\
\text { fenômeno }\end{array}$ & $\begin{array}{l}\text { Aparece uma explicação - } \\
\text { real ou mitológica; às vezes, } \\
\text { as duas versões co-existem. }\end{array}$ \\
\hline
\end{tabular}

As histórias fragmentárias das personagens diferentes completam uma a outra, e, juntas, ajudam a esclarecer o sentido dos acontecimentos misteriosos. A parte mais importante do espaço narrativo, usualmente, é escondida no final do texto, mas não necessariamente no final do enredo. A explicação dos eventos fantásticos não é revelada até o último momento, criando no leitor um pressentimento de um desenlace inesperado.

${ }^{268}$ MANN, 1978, pp. 72-73. 
Estrutura narrativa semelhante pode ser observada em A Terrível Vingança. A heroína Katerina conta a história do horrível feiticeiro (Dizem que nasceu tão pavoroso... ${ }^{269}$ ) - ela ativa a magia na novela. Os eventos fantásticos começam a acontecer. Os heróis procuram uma explicação real para os eventos. Por exemplo, Danilo condena o pai de Katerina à morte por ter traído a pátria, e não porque ele lança feitiços. A morte do pequeno Ivan pode ser causada por uma doença, e não magia negra do feiticeiro. Somente no final, depois de mais uma cadeia de eventos fantásticos e misteriosos, o leitor percebe os acontecimentos através das "lentes" da história antiga de Petró e Ivan. A narrativa do velho bandurrista, no último capítulo, contém uma explicação do perecimento trágico da família de Danilo e traz para o enredo uma dimensão mitológica, associada, na obra, aos temas do clã, do crime e da culpa posterior dos descendentes do criminoso - todos esses temas importantes para a poética do gótico. Lótman assim comenta a última narrativa da novela: “O maldoso Petró, matando seu irmão adotivo [...] se torna iniciador de um mal novo e sem precedentes. Seu crime não fica no passado: gerando uma cadeia de novos crimes, ele continua a existir no presente e a crescer continuamente. A expressão deste conceito é a imagem de um morto que cresce debaixo da terra com cada crime novo ${ }^{270}$,"

Nas outras novelas gogolianas, o esquema narrativo varia. Em $A$ noite da véspera do dia de Ivan Kupala, depois da ativação do enredo gótico pelo narrador, que introduziu no enredo o personagem demoníaco Bassavriuk, o protagonista participa do episódio fantástico da novela. Depois disso, os rumores sobre a origem da riqueza inesperada do Petró surgem na aldeia: De onde, senão do tentador de todos os seres ortodoxos, chegou a ele essa riqueza toda? De onde ele podia tirar um montão de ouro assim $?^{271}$. Alguns eventos, como o desaparecimento do irmão de Pidorka, recebem uma explicação real. Os outros continuam um mistério para as personagens: a doença de Petró e a sua morte inesperada, o fogo na casa do casal, a decisão inesperada de Pidorka de ir para a peregrinação. A história inteira de Petró pode ser vista como um acontecimento trágico, mas cotidiano, em uma das famílias, mas ao mesmo tempo - como um encontro fantástico com o diabo e a venda da alma.

Em Uma noite de maio, o protagonista ativa o enredo gótico. Ele conta a história da pánnotchka e a bruxa e, logo depois, penetra o espaço mágico. Ele é o único que sabe a razão verdadeira dos fenômenos fantásticos. O protagonista também duvida da realidade dos

\footnotetext{
${ }^{269}$ GÓGOL, 1990, p. 46.

${ }^{270}$ LÓTMAN, I. M. “Zvoniátchi v prádedniuiu slavu”. In (1958-1993). Sankt-Peterburg: Iskusstvo-SPb, 1997. p. 108.

${ }^{271}$ GÓGOL, 1976, tomo I, p. 49. .O rússkoi literature. Stat'i i isslédovaniia
} 
acontecimentos, porque tudo acontece durante o seu sonho. Mas a carta do comissário que ele trouxe do outro mundo serve para ele como uma prova da sua viagem ao outro mundo.

Em A Carta Perdida, a composição narrativa é parecida: uma personagem secundária conta que sua alma foi vendida ao diabo. A sua história ativa os poderes mágicos, e depois o protagonista começa a agir no espaço fantástico - o inferno. O herói não precisa de uma explicação dos eventos, porque, para ele, são completamente justificados e fazem parte do seu mundo.

A existência na narrativa das "testemunhas reais" cria uma ilusão da verossimilhança dos eventos descritos, mesmo fantásticos. Em A noite véspera do dia de Ivan Kupala, uma das personagens-narradoras, "a tia do falecido avô", é também participante direta da ação: ela encontra o protagonista na taberna antes dele assinar o pacto com o diabo. Ela serve vodca aos hóspedes no casamento dos namorados. Em A Carta Perdida, o narrador conta a história do seu avô, que foi a personagem principal da história.

A multiplicidade dos planos narrativos, no texto gótico, ajuda o autor a "objetivar" o seu ponto de vista sobre os acontecimentos. Cada narrativa faz o leitor acreditar que são independentes da vontade do autor - são os contos dos "outros". A introdução de um narrador fictício, a quem o autor confia contar as histórias, é um procedimento literário, popular já nos meados do século XVIII, na era "dourada" do gótico. Os contadores das histórias que representam camadas sociais e culturais diferentes, suas conversas ao lado de uma lareira na mesa festiva são típicos também para a literatura da época do romantismo. No século XIX, este procedimento foi usado, frequentemente, por Walter Scott. O autor escocês também criou uma tendência de inserir, no texto, um editor fictício, que publicava os contos das outras pessoas (por exemplo, ele fez isso na coletânea Tales of my landlord). Mantendo o estilo peculiar de cada narrador, o editor afastava o autor ainda mais das suas personagens, fazendo o seu ponto de vista sobre eles mais "objetivo".

Gukóvski conectou a composição narrativa (autor-editor-narrador), em Noites, à tradição dos romances de $\mathrm{Scott}^{272}$. A estudiosa italiana G. Strano também indica que existe uma "conexão genética" entre o colmeeiro Rúdyi Pankó, de Noites em uma granja, e o narrador principal de Tales of my landlord, Jedediah Cleishbotham. Porém ela salienta que "[...] no texto das novelas gogolianas, as fontes europeias e russas se cruzam e sofrem uma transformação: amplificação, estilização, microcitações, detalhes, referências, reminiscências

${ }^{272}$ GUKÓVSKI, 1959, p. 41. 
- tudo isso cria uma montagem complexa ${ }^{273 "}$. Em Noites, Gógol segue o mesmo procedimento que Scott: são publicadas as histórias dos "terceiros", moradores de Dikanka: do diácono Fomá Grigórievitch (A noite na véspera do dia de Ivan Kupala, A Carta Perdida), do polonês de caftan cor de ervilha-verde (Uma noite de maio), do amador anônimo das histórias terríveis (A Terrível Vingança), e outros, enquanto o colmeeiro simplesmente organiza a coletânea, sendo, ao mesmo tempo, o autor dos dois prefácios. Uma pesquisa recente, porém, revela que Rúdyi Pankó pode ser também visto como o autor da novela $A$ Noite de Natal ${ }^{274}$.

Finalmente, os numerosos narradores e alguns elementos narrativos do texto, como bisbilhotices e micro-histórias, podem ser considerados uma espécie de jogo literário. Eles desorientam o leitor: frequentemente, faz-se difícil entender quem está contando a história no momento, se é possível acreditar no narrador porque a sua memória, é impossível descrever, como é ruim $^{275}$. Esse procedimento cria, no leitor, um pressentimento de algum mistério, que cresce no decorrer dos eventos. O caráter confuso do enredo gótico é, especialmente, visível nos contos do diácono Fomá Grigórievitch: usando várias vezes o pronome "nós", ele apaga a diferença entre si próprio e o seu falecido avô, e os eventos do passado e do presente estão entrelaçados em um desenho engenhoso. O diácono assim descreve esse estado de espírito: $E$ ainda mais quando se enfia nisso algum parente, avô ou bisavô, - aí, então, [...] é como se me metesse na alma do bisavô ou a alma dele estivesse brincando em mim... ${ }^{276}$. Para a poética gogoliana, esse procedimento é típico: o herói e o seu antepassado são sempre conectados como os representantes do mesmo clã e podem ser vistos como única pessoa.

Por causa da importância crucial das funções aqui mencionadas, a personagem central para a poética do gótico é a figura do narrador. O mais importante não é o conteúdo e o enredo das histórias, mas quem as conta e qual é o modo como elas são contadas. Segundo Strano, dos hóspedes-narradores, todos conterrâneos de Pankó, dependem

[...] não só os temas, mas também o tom e o estilo das novelas: o procedimento principal do texto é skaz [...] ou, na pesquisa de V. Vinogádov, uma "transposição condicional" dos vários componentes da língua (linguagem popular, linguagem dos camponeses, pequeno-burgueses,

\footnotetext{
${ }^{273}$ STRANO, G. Evropéiskie e rússkie literatúrnye istótchniki v tvórtcheskom protsesse Gógolia. In MANN (org.), 2003, p. 297.

274 SÓBOLEV, Lev. Netchístaia sila $v$ Nótchi pered rojdestvom (vídeo). Disponível em: <http://arzamas.academy/special/ruslit/episodes/20>. Acesso em: 11 de abr. de 2015.

${ }^{275}$ GÓGOL, 1976, tomo I, p. 177.

${ }^{276}$ GÓGOL, 2014, p. 96.
} 
nobres provincianos, jargão literário, poesia popular, fala ucraniana), ou também - "heteroglossia", segundo Bakhtin ${ }^{277}$.

Eikhenbaum, no seu famoso artigo sobre a novela $O$ capote, salienta que, em Gógol, o enredo não desempenha um papel organizador no texto. No primeiro plano, está o narrador, que apenas usa o enredo para entrelaçar os procedimentos estilísticos diferentes. O objetivo do narrador, nesse sentido, é criar uma ilusão de um acontecimento verdadeiro, apresentado como um fato, mas não conhecido por completo pelo narrador ${ }^{278}$.

O uso amplo, em Noites, dos relatos verbais está também relacionado à base folclórica da coletânea. Os enredos das novelas são inspirados nos contos populares ucranianos, que, em russo, são chamados de "bylitchki". O gênero tem suas raízes na palavra "byl", que significa "uma causa verdadeira". Pode-se entender uma bylitchka como um análogo de ghost-story, porque é um relato oral sobre o encontro dos camponeses com alguns fenômenos sobrenaturais, como bruxas, diabos, fantasmas e outras 'forças impuras' ${ }^{279}$.

Para observar melhor as funções aqui descritas, optou-se por caracterizar a imagem do editor e cada narrador que é mencionado nos textos, novela por novela. Começaremos com o editor Rúdyi Pankó e os narradores principais (Fomá Grigórievitch, o polonês e o narrador "escuro"), usando para isso também as informações dos dois prefácios, e depois analisaremos as imagens dos narradores específicos de cada novela, alguns dos quais são personagens típicos para o enredo gótico.

Rúdyi Pankó é o editor e autor dos prefácios. Suas palavras podem ser interpretadas como um certo "manifesto literário" do próprio Gógol. Na sua fala, ele cria um sistema de oposições, entre as quais estão Petersburgo/Dikanka, língua russa oficial /língua eslava eclesiática, educação/sabedoria popular, e a mais importante - o estilo das histórias (complicado e requintado, mais próximo da literatura "culta", como são as histórias do polonês/simples e divertido e mais próximo da fala popular, como são os contos de Fomá Frigórievitch). Para provar o seu ponto, o colmeeiro conta a história de um estudante do latim, narrada para ele por Fomá Grigórievitch:

\footnotetext{
${ }^{277}$ STRANO, 2003, pp.299-300.

278 ĖIKHENBAUM, 1986, p. 45.

${ }^{279}$ PETROVA, Maria. As bruxas na obra de Nikolai Gógol: uma evolução da imagem folclórica. pp. 1-2. In Anais do VII Simpósio Nacional da História Cultural - Escrita, circulação, leituras e recepções. São Paulo, 2015. Disponível em: <http://gthistoriacultural.com.br/VIIsimposio/Anais/Maria\%20Petrova.pdf >. Acesso em: $10 \mathrm{de}$ abr. de 2015 .
} 
[...] um estudante que aprendia ler e escrever com algum diácono, chegou na casa do seu pai e tornou-se tal latinista que até tinha esquecido a nossa lingua ortodoxa. A todas as palavras ele acrescenta um us. Uma pá para ele é um papus, uma baba - um babus. Então, uma vez eles foram com o seu pai para o campo. O latinista viu um ancinho e pergunta ao pai: "Como isso se chama, papai, na sua língua?” E pisou, boquiaberto, com seu pé, nos dentes... "Maldito ancinho! - gritou o estudante, encostando a mão na testa e saltando por quase um archin ${ }^{280}[\ldots]^{281}$

Essa pequena história revela a atitude do editor ao estilo sofisticado e refinado dos autores sentimentalistas. Gógol destaca o caráter simples e vivo de "nossa língua ortodoxa" que também inclui os palavrões, mas, ao mesmo tempo, ele não recusa usar a linguagem mais "culta" nos momentos mais líricos do texto. O autor precisa usar todas as ferramentas da linguagem para criar, em Dikanka, a sua imagem do mundo. O principal nas narrativas dos seus heróis é a mistura dos estilos diferentes.

Depois de contar a anedota sobre o latinista, o colmeeiro explica o objetivo do seu livro: entreter o público - quer dizer, não segue nenhum objetivo didático, mas cria uma oposição à literatura da época do Iluminismo.

Além disso, a figura de Rúdyi Pankó indica, para toda a coletânea, o padrão de um contador ideal. O colmeeiro é uma pessoa simples, é um representante do povo, que, para o estilo gótico, é um portador de sabedoria. O personagem sábio, no romance gótico, é geralmente um “criado tagarela”. Na opinião de Botting, "servos, ignorantes e incultos, são supersticiosos, são a classe que acredita em horrores ${ }^{282}$ ". Ao mesmo tempo, o colmeeiro pode ser visto como uma pessoa descomunal, um mediador entre o mundo mágico e o mundo real, particularmente entre Dikanka e Petersburgo - a capital da Rússia que, em uma das novelas de Noites, até cumpre uma função do mundo alheio ${ }^{283}$. Segundo Dmítrieva, o colmeeiro, na tradição popular, "foi dotado de um estatuto de um curandeiro, um feiticeiro, e nas aldeias (assim como os outros "profissionais" - ferreiro, moleiro, caçador, músico) foi respeitado e,

\footnotetext{
${ }^{280}$ Archin - medida de cumprimento na Rússia antiga igual a $0,71 \mathrm{~m}$.

${ }^{281}$ GÓGOL, 1976, tomo I, p. 9.

282 BOTTING, 1996, p. 73.

${ }^{283} \mathrm{Na}$ novela A noite de Natal, a viagem do ferreiro Vakula para Petersburgo pode ser vista como uma viagem ao mundo alheio. Ele cruza uma fronteira, montado num "animal mágico" - o diabo. Toda a cidade, em sua percepção, é coberta de ouro, e dourado. Segundo o pesquisador do folclore, Propp, é relacionado ao reino dos confins. Nas crenças antigas, era a cor do sol e do fogo, que são objetos mágicos para o conto maravilhoso. Para ler mais sobre a presença do conto maravilhoso em Gógol, ver PETROVA, Maria. Proximidade dos contos ucranianos de Nikolai Gógol ao conto maravilhoso. Texto apresentado no VIII Encontro de Letras Orientais e Eslavas, 2013.
} 
ao mesmo tempo, receado, porque era conectado à força impura e o conhecimento oculto, o fato que definiu, em muitos aspectos, a sua função artística na coletânea ${ }^{284,}$.

Do outro ponto de vista, as histórias reunidas pelo colmeeiro podem ser consideradas como um tipo de prato gourmet para os leitores. Não por acaso, Gógol usa, em abundância, adjetivos como "delicioso" e "doce", nos prefácios, e todos os narradores contam as novelas na mesa festiva, comendo uma refeição generosa. O estudioso Karassióv comenta que "se existe um 'colmeeiro', então, como diria uma personagem literária, deve haver o mel também ${ }^{285}$ ". Nesse caso, o mel são as histórias "servidas".

Mais um aspecto da característica do colmeeiro é o seu nome. "Rúdyi” é uma palavra antiga, sinonímica a "ryjii", que, em russo significa, "ruivo". Na tradição oral, as pessoas ruivas eram heróis constantes de canções, anedotas, piadas. O pesquisador Netchipórenko vê, em ruivo, uma espécie de vermelho, e considera, em Noites, a tríade "branco-vermelhonegro" como um código específico dos espaços "próprio", "fronteiriço" e "alheio" 286 . Para Pankó, o mundo da granja é o mundo próprio, branco; o mundo "grande" de Petersburgo é alheio, desconhecido, "escuro"; e o mediador é marcado, de acordo com as regras dos ritos arcaicos, com a cor vermelha.

Unindo esses aspectos da imagem do colmeeiro, o autor cria um personagem contraditório: Pankó é uma autoridade na sua aldeia, mas também é "um simples colmeeiro" para os leitores petersburgueses, que não o conhecem e até podem rir-se dele; ele é uma mistura de um sacerdote e um diabo. Na sua fala, ele facilmente passa do riso para o choro. Pode-se dizer que a figura do colmeeiro é mais um dos numerosos "espaços-fronteiras" nas novelas ucranianas: ele serve como um mediador entre Petersburgo e Dikanka, entre os moradores de Dikanka e os diabos das histórias, entre os narradores "engenhosos" e os narradores "populares". A figura do colmeeiro merece mais atenção, mas um estudo mais profundo não cabe nos limites do presente trabalho.

A Terrível Vingança - o narrador "escuro". Caracterizando as peculiaridades do gênero de A Terrível Vingança, Dmítrieva definiu a novela como a "tragédia do destino". É um gênero específico que é representado na literatura ocidental pelas obras de Tieck, Hoffmann, Grillparzer, com um tipo de estrutura narrativa também característica dessa novela gogoliana: "A sua essência consistia em que a narrativa se desenvolvia, no início, como uma

\footnotetext{
${ }^{284}$ DMÍTRIEVA, 2011, p. 87.

${ }^{285}$ KARASSIOV, L. V. Gógol’ v tekste. Moskvá: Znak, 2012. p. 182.

${ }^{286}$ NETCHIPÓRENKO, I. D. "Ryjie” ili “smechnye” liúdi na Ukraine: ot Gógolia do nachikh dnei. In Logítcheskii análiz iazyká. Iazykovye mekhanizmy komizma. Moskvá: Índrik, 2007. p. 598.
} 
cadeia dos eventos que eram privados de uma conexão interna. E somente no final da novela revelavam-se as premissas remotas das circunstâncias maravilhosas, o que atribuía uma lógica interna ao texto ${ }^{287}$,

O narrador "escuro" de A Terrivel Vingança recebe, no prefácio, uma característica sinistra: Havia entre nós mais um narrador; mas esse (nem seria bom se lembrar dele com a aproximação da noite) desencavava as estórias tão espantosas que o cabelo ficava em pé ${ }^{288}$. Ele conta a história do perecimento da família de Danilo Burulbach. O leitor percebe que a novela vai ter um final infeliz e vai ser terrível, porque o narrador é relacionado à noite, e, portanto, às forças impuras ${ }^{289}$. Ele "escava" as histórias da terra como os mortos das suas covas.

O estilo do narrador "escuro" é diferente da fala de Rúdyi Pankó e dos outros heróis da coletânea. Ele parece mais próximo não da fala popular, mas dos poemas épicos, como, por exemplo, o poema antigo russo $O$ Dito do Exército de Igor ( século XII). As frases possuem seu ritmo, o que é visível desde o início da novela. Destaca-se o uso amplo dos verbos e as repetições das palavras: Ressoam de muitos sons os confins e Kiev. Muitos convidados chegaram à casa do esaul. Naqueles tempos, gostava-se de comer bem, gostava-se ainda mais de beber e gostava-se mais ainda de se divertir ${ }^{290}$.

Segundo Dmítrieva, o substrato principal folclórico desse texto é a canção popular ucraniana $^{291}$. O tom lírico de uma canção é especialmente visível no lamento de Katerina em cima do corpo do seu marido: Marido meu, serás tu quem está aí deitado com os olhos fechados? Levanta-te, meu falcão querido, estende tua mão! Ergue-te. Olha pelo menos uma vez para a tua Katerina, move os lábios, pronuncia ao menos uma pequena palavra! ${ }^{292}$

A estrutura narrativa da novela é complexa: dentro do texto principal do narrador onisciente existem as narrativas dos heróis. Com a ajuda dessas micronarrativas, Gógol, passo a passo, se aproxima do protagonista - o vilão-feiticeiro. No primeiro capítulo, o feiticeiro é mostrado de um modo afastado, por meio dos gritos dos convidados no casamento. Por isso nós enfrentamos o fenômeno repugnante, mas as razões dele permanecem um mistério para

\footnotetext{
${ }^{287}$ DMÍTRIEVA, 2011, p. 98.

${ }^{288}$ GÓGOL, 1976, tomo I, pp. 9-10.

289 A própria oportunidade para uma travessia dos heróis para o mundo mágico surge só na hora certa, que, na obra do escritor, é marcada pelos vários sinônimos da palavra "noite". Em A Terrível Vingança, são as palavras notch'vêtcher (noite); t’má, temnotá (escuridão), vetchérniaia zariá, súmerki (crepúsculo).

${ }^{290}$ GÓGOL, 1990, p. 43.

${ }^{291}$ DMÍTRIEVA, op. cit., p. 96.

${ }^{292}$ GÓGOL, op. cit., p. 69.
} 
nós: O feiticeiro apareceu de novo! - gritavam as mães, agarrando os filhos nos braços ${ }^{293}$. Descobrimos que o feiticeiro apareceu "de novo", e que isso significa uma futura desgraça, mas não sabemos quem ele é, de onde vem etc.

O espaço narrativo também inclui as histórias não contadas, que nós não ouvimos, mas que intensificam o ambiente sinistro e misterioso. São rumores em várias formas: $E$, em todo o canto da grande estalagem do esaul, começaram a se reunir em grupos e a ouvir histórias sobre o prodigioso feiticeiro. Cada um contava uma história diferente, e ninguém sabia ao certo contar nada sobre ele $e^{294}$. É preciso destacar que Gógol via bisbilhotice como um procedimento para introduzir o fantástico no texto. Ele faz uma observação significativa numa das suas cartas: "Estou completamente convencido de que a bisbilhotice é espalhada pelo

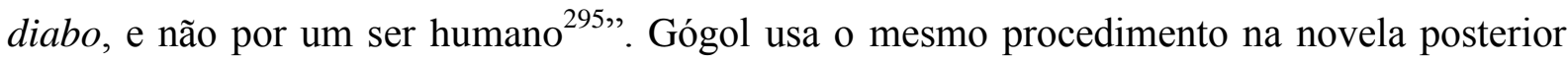
Viy - as histórias isoladas criam uma imagem-mosaico que prepara o herói e o leitor para o encontro com a bruxa na igreja: Cada um procurava por sua vez contar alguma coisa: uma bruxa que chegava à porta de uma casa disfarçada de um monte de feno, que roubava o gorro de pele ou o cachimbo de outro, que cortava as tranças de muitas moças na aldeia, que bebia vários baldes de sangue ${ }^{296}$.

Depois de receber a primeira impressão do feiticeiro, as personagens adicionam outros detalhes a sua história, dão sua característica a ele. No segundo capítulo, Katerina conta sobre a infância do vilão. Ela também sabe pouco dele, mas tenta explicar os motivos das suas ações.

Dizem que nasceu tão pavoroso... e, desde pequeno, nenhuma criança quis brincar com ele. Ouve, pan Danilo, como é terrivel o que dizem: parece que sempre imaginava que todos riam dele. E, se por acaso encontrava alguém numa noite escura que abrisse a boca, sempre lhe parecia mostrar os dentes e rir dele. No dia seguinte, a pessoa era encontrada morta ${ }^{297}$.

As poucas frases em que Danilo fala do feiticeiro introduzem um dos temas principais da novela - o tema da traição, e, especialmente, a traição do clã: Agora mesmo vamos passar pelas cruzes - é um cemitério! Aqui estão apodrecendo os seus antepassados malditos. Dizem

\footnotetext{
${ }^{293}$ GÓGOL, 1990, p. 45.

${ }^{294}$ Idem, Ibidem, p. 45.

${ }^{295}$ MEREJKÓVSKI, Dmítri. Gógol'i tchiort. In GONTCHAROV (Org.), 2009, p. 351., grifo nosso.

${ }^{296}$ GÓGOL, Nikolai. O Capote e outras histórias. Trad. Paulo Bezerra. São Paulo: Editora 34, 2010. p. 192.

${ }^{297}$ GÓGOL, 1990, p. 46.
} 
que todos eles estavam prontos a se vender por qualquer dinheiro a Satanás, com a alma e com os jupans esfarrapados ${ }^{298}$.

É curioso observar a posição do narrador "escuro" em relação aos acontecimentos, porque ela não é idêntica à posição dos heróis. Às vezes, parece que ele se solidariza com a opinião de Danilo. No capítulo X, ele menciona que o vilão atentava contra o Deus ${ }^{299}$. Aqui vemos uma avaliação inequívoca negativa. Mas, ao mesmo tempo, percebemos que o narrador simpatiza com o vilão. Por isso, quando o feiticeiro está esperando sua execução, ele pergunta: $O$ mundo todo está deserto. Triste ressoa o Dniepr. A melancolia instala-se em seu coração. Mas sentirá o feiticeiro esta melancolia? ${ }^{300}$

Finalmente, a figura-chave para a narrativa é o velho bandurrista que surge no último capítulo. Ele é cego, mas corria os olhos como se fosse capaz de ver; e os dedos, com o plectro atado, voavam como vozes pelas cordas que pareciam tocar por si mesmas ${ }^{301}$. A cegueira do bandurrista ainda mais destaca a sua sabedoria e também traz ao leitor as associações com Homero - o cantor famoso dos poemas épicos antigos Ilíada e Odisseia. $\mathrm{O}$ bandurrista, de um modo figurativo, explica as razões para as desgraças que caíram na família de Danilo Burulbach.

A narrativa do velho músico desloca o cronotopo do texto dos tempos antigos para os tempos lendários. É visível uma conexão com a história bíblica de Caim e Abel. Assim como os heróis do Velho Testamento, Petró e Ivan eram como irmãos. Possuído por ciúmes, Petró decidiu matar Ivan, e assim aconteceu o crime nunca visto antes na terra. Diz Ivan ao Deus: Uma grande ofensa me causou este homem: traiu o seu próprio irmão, como Judas, e privouse de minha honrada casta e da minha descendência na terra ${ }^{302}$.

O enredo lendário possui várias conexões com o enredo principal: há uma traição e um assassinato de uma criança. Petró atira no abismo não somente Ivan, mas seu pequeno filho; no enredo principal, o feiticeiro mata seu neto, também chamado de Ivan. A cena em que Ivan pede a Petró para poupar o seu filho é profundamente trágica: Meu irmão querido! Espeta-me com a lança, já que assim está escrito, mas salva o meu filho! Que culpa tem essa criança inocente para perecer de uma morte tão cruel? ${ }^{303}$ Mas Ivan não tem piedade por uma criança,

\footnotetext{
298 GÓGOL, 1990, p. 47.

${ }^{299}$ Idem, Ibidem, p. 71.

${ }^{300}$ Idem, Ibidem, p. 62.

${ }^{301}$ Idem, Ibidem, p. 81.

${ }^{302}$ Idem, Ibidem, p. 83.

${ }^{303}$ Idem, Ibidem, p. 82.
} 
e assim atrai uma maldição para sua família. Ele "reescreve" o futuro do seu clã. É por isso que morre o pequeno filho de Danilo, apesar de não ter nenhuma culpa - assim está escrito.

O bandurrista, como um narrador, representa uma consciência arcaica, com suas leis de comportamento. Uma das categorias mais importantes para esse tipo de consciência é o tempo, em que os "primeiros" acontecimentos do universo não se transformam simplesmente em lembranças distantes, eles existem de verdade, por um tempo indefinido. Cada novo acontecimento não é algo diferente do seu antecessor, mas representa uma renovação de um acontecimento-base. Assim, em A Terrivel Vingança, o assassinato de um irmão por outro é uma renovação de pecado de Caim, que é eterno e irreparável. Os crimes novos, nunca vistos antes, são mais terríveis em termos da consciência arcaica ${ }^{304}$.

A culpa do clã contra outro clã conecta todos - os vivos e os mortos. A lei de vingança "vida por vida" se estende até a lei "descendente por descendente", "clã por clã". Muitos textos góticos seguem as mesmas regras - os descendentes sempre são responsáveis pelos crimes dos seus avôs. Eles devem tentar concertar o ocorrido ou, se aquilo for impossível, respondem pelos crimes ocorridos. $\mathrm{O}$ tema de clã é associado com vários temas no enredo gótico, entre eles - o tema da maldição familiar, o tema da vingança e o tema do mistério.

O clã, como uma forma básica da existência social, é mostrado no momento de sua desintegração. A fonte dessa desintegração é o conflito trágico entre os velhos e os jovens (o feiticeiro/Danilo e Katerina). Ele acaba mal para os jovens, que, na verdade, precisam representar o futuro de toda a estrutura patriarcal: o clã está no limiar da sua autodestruição. O estudioso Oleg Zasslávski, comparando A Terrível Vingança com o romance gogoliano não concluido Hetman (1832), assim caracteriza o tema do clã na novela:

O feiticeiro próprio destrói seu clã, sucessivamente matando o genro, o neto e a filha. E a "hora de julgar as maldades" do feiticeiro chega exatamente depois dele ter assassinado o último do seu clã. Esses crimes são chamados de "vileza sem par", de "o ato terrível". Visto que o crime mais terrível é a destruição do clã, o pecador mais terrível é aquele que destrói o clã. E como ele é o último, quer dizer, o clã para de existir com ele, ele precisa pôr fim ao seu próprio clã. $\mathrm{O}$ paralelo simbólico a isso é a imagem do morto que debaixo da terra roe a si próprio ${ }^{305}$.

Além de Caim e Abel, a história do bandurrista aproxima Petró de Judas, o traidor de Jesus. Assim como Judas, no poema de Dante, “O inferno”, Petró, no final da história, está no

\footnotetext{
${ }^{304}$ LÓTMAN, 1997, p. 108.

${ }^{305}$ ZASSLÁVSKI, Oleg. Zámyssel 'Gét'mana': rekonstrúktsiia siujeta i kompozitsii. In MANN (Org.), 2003, p. 141.
} 
fundo de um grande abismo. A vingança escolhida por Ivan é uma reminiscência a mais uma traição bíblica - do anjo caído Lúcifer, que atentou contra o próprio Deus. O malévolo feiticeiro, como Lúcifer, cai de uma montanha: E quando chegar a hora de julgar as maldades desse homem, elevai-me, Deus meu, deste abismo num cavalo até a mais alta montanha, e que ele venha a mim, e então o jogarei dessa montanha no mais profundo abismo $^{306}$.

A camada mitológica está em uma relação peculiar, mas não conflitante com a ação principal da novela. Ela encerra a ação, revela o oculto e sugere sua própria explicação dos eventos. Antes de saber da história de Ivan e Petró, o leitor assiste a vários fenômenos fantásticos na novela: o terremoto, o levantamento dos mortos e a morte horrorosa do feiticeiro - tudo isso também aparece no mito. Segundo Mann, o caráter irrefutável da narrativa mitológica, sua coincidência com os eventos da novela transtornam a sua perspectiva: o final do texto se transforma no começo da ação trágica, e o destino do feiticeiro, de Danilo, de Katerina vira o final verdadeiro da história. A narrativa do bandurrista também muda a impressão original sobre o vilão e o caráter da "terrível vingança ${ }^{307 "}$. Segundo Arlete Cavaliere,

\footnotetext{
Observa-se, então, que os dois blocos de acontecimentos que se apresentam justapostos e consecutivos na linha narrativa do conto, acabam por se interpenetrarem, estabelecendo uma relação de causa-efeito, passadopresente, tendo como polo aglutinador dessa relação a figura heróica do bogatir que aparece no conto simultaneamente como perseguidor e perseguido, punidor e punido, sujeito e objeto de um esquema dialético herói-anti-herói, cujo controle é exercido no universo do conto por um Deuspai para quem não há indulgência ${ }^{308}$.
}

Sumarizando todas nossas observações, pode-se afirmar que cada narrativa inserida na novela tem seu próprio sentido, mas a camada mitológica possui importância crucial: ela amplia o espaço e o tempo da novela, conecta a época heroica dos cossacos aos tempos préhistóricos, liga o crime do feiticeiro à primeira traição na terra e mostra o caráter inevitável do castigo por ele.

A Noite na véspera do dia de Ivan Kupala - o narrador "popular". A estrutura narrativa dessa novela é uma das mais complicadas em toda coletânea: no seu núcleo, há o relato de um diácono, que ouvira a história de seu falecido avô, ainda na infância, narrativa

\footnotetext{
${ }^{306}$ GÓGOL, 1990, p. 83.

${ }^{307}$ MANN, 1978, pp. 48-49.

${ }^{308}$ CAVALIERE, 1990, p. 160.
} 
esta que era já uma versão de algumas observações da tia desse avô. São acrescentados, também, os outros elementos narrativos que não possuem uma conexão direta com o enredo principal: um conflito entre o diácono e os "escribas", narrado pelo colmeeiro no prefácio da novela, várias digressões de Fomá Grigórievitch sobre "os velhos tempos”, pequenas histórias dos encontros dos outros moradores da aldeia com os espíritos diabólicos, e, finalmente, uma mensagem curta de um cossaco de Kiev sobre o destino da heroína.

O diácono Fomá Grigórievitch é o narrador principal não somente dessa novela. Ele conta três histórias das oito na coletânea: A noite na véspera do dia de Ivan Kupala, A Carta Perdida e Um lugar encantado. Tendo crescido e passado a vida inteira na granja, perto de Dikanka, ele guarda as lendas familiares. O personagem frequente de seus contos é o seu velho avô, o cossaco que sabia muitas histórias sobre os tempos heroicos da Ucrânia. Além disso, o avô é uma testemunha e um participante imediato de alguns acontecimentos, conhece a força impura de perto e sabe lidar com ela. É, constantemente, mencionado nas narrativas, que o avô é "falecido" - em primeiro lugar, para destacar a distância temporal entre o narrador e os acontecimentos, e, em segundo lugar, para fazer possíveis os encontros dos heróis com os fenômenos fantásticos ${ }^{309}$.

Rúdyi Pankó, no primeiro prefácio, dá uma característica detalhada da aparência do diácono:

Que histórias ele sabia contar! [...] Ele nunca se vestiu com um roupão de linho, que vocês vão encontrar em muitos diáconos das aldeias; mas vocês devem visitá-lo nos dias úteis. Ele sempre vos receberá com um roupão feito de um feltro fino [...] pelo qual pagara, em Poltava, pouco menos que seis rublos por um archin. Em suas botas, todo mundo da granja vai confirmar, não há um fedor de alcatrão, mas todos sabem que ele as limpava com o melhor toucinho, que, eu acho, que algum mujique, com prazer, colocaria em seu mingau. Ninguém vai dizer também que ele, em momento algum, esfregasse o seu nariz com a aba do seu roupão, como fazem algumas pessoas da sua profissão: mas tirava do seu peito um lenço branco, dobrado com cuidado e bordado em todas as margens com fios vermelhos, e, tendo feito o que é preciso, dobrava-o de novo $[\ldots]^{310}$.

A característica dada pelo colmeeiro é um procedimento cômico: ele não explica como são as histórias de Fomá Grigórievitch, como são as suas qualidades narrativas. Mas, usando alguns detalhes, o autor tenta destacar o seu herói dos diáconos típicos do teatro de vertep,

\footnotetext{
${ }^{309}$ Vladímir Propp (PROPP, 1997) explica que somente a personagem de algum jeito conectado à morte (um morto ou um xamã que possui conhecimento oculto) tem direito a atravessar a fronteira entre o reino dos vivos e dos mortos. Esse tema foi inspirado, em Gógol, pelo folclore eslavo.

${ }^{310}$ GÓGOL, 1976, tomo I, pp. 8-9
} 
que são, geralmente, retratados como simplórios e amadores de comer e beber (como é descrito, por exemplo, o diácono de $A$ noite de Natal) ${ }^{311}$. Fomá Grigórievitch é uma pessoa respeitável, asseada, com uma certa "pretensão a ser culto": ele se veste em feltro - o material para uma roupa mais cara - e até usa óculos. Ele é diferente, por exemplo, do escrivão de Uma noite de maio, um personagem cômico, que se veste em linho, um material barato (bombachas de linho e num colete da cor de fermento para vinho ${ }^{312}$ ).

Provavelmente uma feição mais importante do caráter de Fomá Grigórievitch é a sua origem popular. Ele é um representante da granja, e não da cidade. No âmbito da poética do gótico, ele é um sábio que observa o passado através de lendas e histórias do povo, e, por isso, pode dar aos acontecimentos uma interpretação justa e adequada. A sabedoria do diácono é sublinhada por Rúdyi Pankó: Eis um exemplo para vocês, Fomá Grigórievitch; ao que parece, nem uma pessoa nobre, mas se olhassem para ele, no seu rosto brilha algum ar de importância ${ }^{313}$.

Ao mesmo tempo, o autor trata o seu personagem com certa ironia. Isso é especialmente visível no momento em que o diácono fala sobre os sabichões que escrevinham nas cortes e até leem em língua oficial e que, se lhes derem um simples livro sagrado, nem entenderiam um A sequer, mas, para arreganhar os dentes sem vergonha, eles têm aptidão ${ }^{314}$. O diácono, uma pessoa tão respeitada na aldeia, tem medo de ser zombado. Essa feição, de um modo inesperado, o aproxima tanto de seu oponente, o polonês, quanto do feiticeiro de A Terrível Vingança, que também tinha grande medo do riso.

Como um narrador, Fomá Grigórievitch aparece pela primeira vez em A noite da véspera do dia de Ivan Kupala. O editor conta que ele detestava repetir a mesma coisa. Por vezes, se alguém lhe implorasse para narrar alguma história novamente - veja só-já metia algo novo ou a modificava tanto que nem dava para reconhecê-la ${ }^{315}$. Essa peculiaridade, mencionada pelo autor, faz o leitor atento duvidar das palavras do diácono, porque, mesmo quando relata as "causas verdadeiras", ele pode mudar a narrativa de acordo com seu arbítrio.

O diácono dá uma característica viva e detalhada a todos os espaços em que acontece a ação (a granja, Medvéji Ovrag), às personagens (Bassavriuk, Petró, Pidorka, seu pai Korj). Na

\footnotetext{
${ }^{311}$ Isso é explicado detalhadamente no trabalho de BARABACH , I. I.Gógol' i traditsii staroukraínskovo teatra (Dva etiúda). In N. V. Gógol' i teatr: III gógolevskie tchténiia. Moskvá: Knijnyi dom "Universitet”, 2004. pp. 25-39.

${ }^{312}$ GÓGOL, 1976, tomo I, p. 70

${ }^{313}$ Idem, Ibidem, p. 93.

${ }^{314}$ Idem, Ibidem, pp. 40-41.

${ }^{315}$ Idem, Ibidem, p. 39.
} 
sua fala, observam-se numerosas frases que mostram sua opinião sobre tudo. Por exemplo, ele dá a sua avaliação a beleza da heroína:

Ah, que o senhor não me deixe mais cantar o Aleluia no coro da igreja se não é verdade que eu, neste mesmo lugar, a cobriria de beijos, apesar de que fios grisalhos estão se infiltrando por toda a velha floresta que brota do meu cocuruto, e ainda, bem ao lado, está a minha velha, como uma pedra nos sapatos $^{316}$.

Ele simpatiza com os problemas dos namorados e fala com muita emoção sobre o destino de Petró e Pidorka. Esse procedimento aproxima o leitor da narrativa, ao mesmo tempo, deixando para o escritor uma oportunidade para ser "objetivo", porque ele fala por meio de outra pessoa:

Contudo, não teria vindo à mente de Korj nenhuma má intenção se uma vez (aí, é claro como água que não fora outro senão o tinhoso que tentou) não viesse à cabeça de Petró, sem pensar bem, na entrada da casa, lascar um beijo - como eles dizem - de todo o seu coração, nos lábios rosados da cossaca. Aquele mesmo tinhoso (que ele, o filho de uma égua sonhe com a santa cruz!) levou o velho caduco a abrir a porta da casa, de bobeira ${ }^{317}$.

Algumas frases do diácono podem ser vistas como digressões. O narrador, constantemente, invade o enredo com suas observações e lembranças, volta aos níveis exteriores da narrativa - menciona os tempos atuais ou apela diretamente ao leitor. Assim, o autor confunde o leitor, fazendo-o adivinhar quem conta a história, de que período temporal se fala. Podemos citar, como exemplos, a descrição do casamento nos velhos tempos, um trecho sobre a mudança das estações do ano e alguns outros trechos pequenos. Essas digressões atrasam a ação, ajudam o autor a adiar o final dramático da novela. Também elas mostram o tempo dos eventos: o autor não tenta criar no leitor o efeito de presença no passado, mas, ao contrário, constantemente destaca a distância da ação do presente. Mann salienta que a maioria das novelas de Noites possui uma clara oposição entre os velhos e os

\footnotetext{
${ }^{316}$ GÓGOL, 1976, tomo I, p. 43.

${ }^{317}$ Idem, Ibidem.
} 
novos tempos: "Não importa do que se fala, do que se trata, tudo "nos velhos tempos" era diferente, melhor. 'Nos velhos tempos, o casamento era incomparável ao atual, 318,".

Os trechos cômicos (o episódio com Korj, o acidente com a tia no casamento, a história da bacia que saiu pulando da casa), na narrativa de Fomá Grigórievitch, alternam com os acontecimentos horríveis ou trágicos (a desgraça de Petró e Pidorka, o crime no Barranco de Urso, a doença de Petró). Esse aspecto da poética gogoliana é característico também do romance gótico. O primeiro autor gótico, Horace Walpole, tinha mencionado a mistura do trágico e do cômico já no prefácio à segunda edição do seu romance $O$ castelo de Otranto. Walpole via neste procedimento o contraste entre as personagens principais, com seus sofrimentos emocionais, e as personagens secundárias, com sua ingenuidade engraçada ${ }^{319}$.

A história do conflito entre o diácono e um "escriba" que roubou a sua história (diz sobre ele: Para nós, gente simples, fica até complicado nomear esses senhores, pois escribas não são, mas são como revendedores nas nossas feiras ${ }^{320}$ ) mostra algumas contradições na posição do autor na coletânea. À primeira vista, parece que o escritor toma o lado de Fomá Grigórievitch: Cuspam, então, na cabeça daquele que imprimiu isso! Está mentindo, moscal filho da mãe! Não foi assim que eu contei. Parece que alguém tem um parafuso a menos na cabeça! ${ }^{321}$. A tradição crítica viu nessa linha uma alusão ao conflito do próprio Gógol com o editor da revista “Otétchestvennye zapiski”, P. P. Svin'in, que tinha publicado a novela com muitas alterações em fevereiro de $1830^{322}$. Mas as pesquisas mais recentes mostram que essa parte do texto é um jogo literário em que Gógol queria envolver o leitor. Se nós reconhecermos Svin'in no senhor que tinha "arrancado" a história do diácono, então destruiremos a fronteira entre o autor e o narrador - fato impossível para a poética gogoliana. Também, na imagem de moscal, pode-se ver algumas feições características do próprio Gógol, porque ele, segundo as leis de Dikanka, é exatamente um escriba que publica os "livrinhos", e foi assim que ele publicou a sua coletânea - "arrancando" as histórias divertidas dos seus parentes.

Como já mencionamos antes, a estrutura narrativa de $A$ noite da véspera do dia de Ivan Kupala contém várias histórias inseridas. Se no prefácio à novela o narrador é, provavelmente, o colmeeiro que conta a história sobre Fomá Grigórievitch, depois o próprio

\footnotetext{
${ }^{318}$ MANN, I. V. Rússkaia literatura XIX veka. Èpokha romantizma. Moskvá: RGGU, 2007. p. 382.

${ }^{319}$ Apud VATSURO, 2002, p. 10.

${ }^{320}$ GÓGOL, 1976, tomo I, p. 39.

${ }^{321}$ Idem, Ibidem, p.40.

${ }^{322}$ Apud. STEPÁNOV, A.I. Gógol'v “Otetchestvennykh zapiskakh”, 1830. InRússkaia literatura. Trudy otdela nóvoi rússkoi literatury. Tomo I, Moskvá-Leningrad: 1957. pp. 46-79.
} 
diácono começa a falar. Mas as narrativas continuam multiplicando-se: o leitor lida com o discurso indireto, um relato do outro relato, porque Fomá Grigórievitch conta uma história que ele tinha ouvido do seu falecido avô. Esse avô nunca mentira em toda sua vida, e o que ele, às vezes, dizia era exatamente o que tinha acontecido ${ }^{323}$. Aqui o leitor atento pode ver mais uma contradição: o avô nunca mentira, mas Fomá Grigórievitch detestava repetir a mesma coisa e sempre acrescentava as coisas novas no seu relato. Esse procedimento, junto ao tempo da ação distante (mais de cem anos atrás), livra o autor de uma necessidade de explicar os acontecimentos fantásticos no texto.

O diácono destaca que tinha ouvido a história quando era uma criança. É um detalhe importante para a novela, porque, na poética gogoliana (e no romance gótico, às vezes), as crianças são os mensageiros dos acontecimentos maus. Com sua alma pura, elas são as primeiras a sentirem e assinalarem a aproximação das forças impuras. Por exemplo, em A Terrivel Vingança, o pequeno filho de Danilo começa a chorar quando ouve os mortos saindo das covas no cemitério. Em A noite da véspera do dia de Ivan Kupala, o pequeno irmão da heroína aparece na floresta junto à bruxa. O terrível na narrativa, conforme Mann, em Noites, é mostrado através da percepção de uma criança: “A história de Basavriuk foi ouvida por Fomá Grigórievitch quando ele era criança: as lendas heróicas não 'atraíam tanto nossa atenção quanto as histórias sobre acontecimentos antigos e estranhos, as quais nos davam arrepios por todo o corpo e deixavam o cabelo de pé, 324 ". O pesquisador explica que, em Gógol, a criança possui o poder superior sobre o mundo e tem pressentimento agudo infelizmente, não dos acontecimentos bondosos ${ }^{325}$.

Além de Fomá Grigórievitch e o avô-mediador, há, na novela, mais um narrador a tia do falecido avô. Ela não só conta algumas partes desconhecidas da história ao leitor, mas também é um participante direto dos acontecimentos. Ela conhece as personagens, pessoalmente, e possui sua própria opinião sobre elas: A própria tia do meu avô, que naquele tempo era dona da taberna na atual estrada de Opochniá, onde frequentemente farreava Bassavriuk [...] dizia justamente que não aceitaria presentes dele nem por todas as riquezas do mundo ${ }^{326}$. Ela está presente no casamento de Petró e Pidorka, ocasião em que acontece um acidente engraçado com ela.

\footnotetext{
${ }^{323}$ GÓGOL, 1976, tomo I, p.40.

${ }^{324}$ MANN, 1988, p. 26.

${ }^{325}$ Idem, Ibidem.

${ }^{326}$ GÓGOL, op. cit., p. 42.
} 
A tia também possui conhecimento intuitivo: ela sente que algo ruim pode acontecer com Petró porque ele não tem família, e fazia de tudo para lhe dar parentes, mesmo que o pobre Petró tivesse tanta necessidade deles como nós temos das nuvens de antanho ${ }^{327}$. Belyi, no estudo "Mestria de Gógol", viu os órfãos como as pessoas sujeitas à influência do mundo alheio: "O tema da ausência da família é entrelaçado com a força 'impura', que tem efeito sobre os renegados que tinham perdido a sua terra e que procuravam os seus tesouros; o tesouro principal, a conexão com o clã, foi perdido ${ }^{328}$ ".

O relato da tia do avô sobre o pai de Petró aproxima essa personagem do feiticeiro de A Terrível Vingança. Segundo a tia, o pai de Petró estava em Zaporójie, antes disso - caíra prisioneiro dos turcos, sofrera Deus sabe que tormentos e, por algum milagre, tendo se disfarçado de eunuco, dera no pé $e^{329}$. Essa descrição, de modo curioso, parcialmente se repete na história do feiticeiro. Ele também estava ausente nas terras distantes, e, por isso, perdeu a conexão com os cossacos: Há um ano apenas, ele vivia em Zadnepróv, mas durante vinte e um anos estivera desaparecido sem dar notícias e voltara para junto de sua filha quando esta já estava casada e já dera à luz o filho ${ }^{330}$.

No final da novela aparece um cossaco que veio em Dikanka de Kiev. Ele é uma pessoa de fora, não conectada ao enredo principal. Com sua ajuda, o autor conta o que acontecera com Pidorka depois dos eventos terríveis da novela - um tipo de epílogo da história. Destaca-se o caráter não muito confiável da fonte: ... contou que tinha visto, no monastério, uma monja, magra como um esqueleto, que rezava sem parar e na qual os conterrâneos, por todos os sinais, reconheceram Pidorka ${ }^{331}$. A função do cossaco, então, é "fechar" a narrativa principal, deixando para Fomá Grigórievitch falar sobre os outros acontecimentos estranhos na velha aldeia.

Como se pode observar, em A Noite na véspera do dia de Ivan Kupala, a estrutura narrativa da novela é complicada com vários elementos. A imagem do autor divide-se, fragmenta-se em vários "espelhos", dos quais consiste o sistema autor-editor-narradores. Nenhum dos co-criadores do seu texto-mundo possui todos os pedaços do mosaico, mas, juntos, eles criam uma imagem viva e multifacetada.

Uma noite de maio, ou a moça afogada - narrador "engenhoso". O narrador principal dessa novela não é indicado diretamente. O estilo do texto é mais próximo da linguagem

\footnotetext{
${ }^{327}$ GÓGOL, 1976, tomo I, p. 42

${ }^{328}$ BÉLYI, 1934, p. 51.

${ }^{329}$ GÓGOL, op. cit., p. 42.

${ }^{330}$ Idem, 1990, p. 44.

${ }^{331}$ Idem, 1976, tomo I, p. 52.
} 
literária, característica do sentimentalismo, com suas frases longas e sofisticadas. Por isso não se pode atribuir a "autoria" do texto a Fomá Grigórievitch, mas é possível pressupor que a história é do polonês de caftan cor-de-ervilha verde, Makar Nazárovitch, um "narrador engenhoso" que conta suas histórias de um modo complicado e esperto, como nos livros impressos ${ }^{332}$.

O polonês é um personagem peculiar em Dikanka. Sendo seu representante, ele é, ao mesmo tempo, uma pessoa alheia. Em primeiro lugar, ele é de origem nobre. Para o colmeeiro, nobreza é sinônimo de arrogância: Vou dizer para vocês, amáveis leitores, que não há nada pior no mundo que essa nobreza. O tio dele outrora era um comissário, e então ele anda com seu nariz para cima ${ }^{333}$.

Além disso, Makar Nazárovitch tem caráter difícil e conflitante. Ele aparece duas vezes na coletânea e ambas as vezes briga com o diácono, e somente o colmeeiro salva a situação. De certo modo, o polonês é uma "ovelha negra" na sociedade de Dikanka. Ele é zombado por todos; as pessoas não entendem bem o discurso dele: Não entendemos nada, nem que a vaca tussa. De onde ele pegou tais palavras! $!^{334}$. Nesse sentido, ele parece o próprio Gógol: o primeiro tomo de Noites recebeu uma avaliação contraditória. Alguns críticos até duvidaram da origem ucraniana de Gógol por causa do seu estilo "engenhoso". Por exemplo, o crítico Polevói assim caracterizou as novelas ucranianas na revista "Moskóvski Telegraf":

Diga o que quiser, mas nós, com nossa razão russa, não entendemos esse pairo nas alturas... Se anotar todos os seus voos altos incompreensíveis, a mão vai cansar... O desejo de imitar o malorussismo travou tanto a sua língua e a sua fala que em alguns lugares nem vamos achar o sentido ${ }^{335}$.

É justo que todos os narradores, assim como outros personagens, sejam, ao mesmo tempo, afastados do autor e representam seu "alter ego". Mas Makar Nazárovitch até tem uma aparência semelhante com o autor. Por exemplo, o colmeeiro fala de um nariz grande do polonês, com que ele podia aspirar o punhado inteiro de rapé. Nas cartas, Gógol, muitas vezes, fazia piadas sobre o tamanho do seu nariz.

\footnotetext{
${ }^{332}$ GÓGOL, 1976, tomo I, p. 9.

${ }^{333}$ Idem, Ibidem, p.93

${ }^{334}$ Idem, Ibidem, p. 9.

${ }^{335}$ Moskóvski Telegraf, 1831. №17. Parte 41. p. 93. Cf. DMÍTRIEVA, 2011, p. 38.
} 
A estrutura narrativa de Uma noite de maio é mais simples que das outras novelas. $\mathrm{O}$ narrador é onisciente. Dentro da sua narrativa, existem as histórias das personagens - do protagonista sobre a bruxa e do destilador sobre a sogra.

A primeira é a história mais importante para o desenvolvimento da ação. Depois de apresentar os espaços góticos - a casa abandonada e o lago - Levkó ativa o enredo fantástico através da sua fala. Nessa novela, o sobrenatural pode acontecer apenas no passado. Com a lenda, são introduzidas as duas personagens novas - a pánnotchka e a bruxa. O leitor descobre o seu passado e, de acordo com a poética do romance gótico, começa a esperar o encontro com essas personagens. O relato de Levkó, porém, pode ser duvidado, porque o herói não é uma testemunha dos eventos, ele só conta os rumores que existem na aldeia: $O$ que não contarão as babas e o povinho estúpido ${ }^{336}$.

O duplo da história da bruxa é a história do destilador. Vários de seus episódios são uma reflexão cômica do relato de Levkó: a nova esposa de sótnik vem em casa da pánnotchka - o desconhecido vem à casa da sogra: De repente, não se sabe de onde, surge um homem quem ele é, só Deus sabe, - pede permissão para comer também ${ }^{337}$. A bruxa-gata persegue a pánnotchka - o morto persegue a sogra com uma galuchka entre os dentes: Monta na chaminé da casa, o maldito, e ainda guarda uma galuchka na boca. Durante o dia, tudo está calmo; mas, logo que começa a escurecer, é só olhar no telhado, e ali está ele, já subiu na chaminé, esse filho de uma égua ${ }^{338}$. A casa da pánnotchka é amaldiçoada - a casa da sogra é amaldiçoada: Desde aquele tempo, a sogra não tinha paz ${ }^{339}$.

A narrativa do destilador mostra como Gógol consegue transitar pelos conceitos do trágico e cômico. Qualquer fenômeno no mundo de Dikanka, potencialmente, pode ser visto como triste e engraçado ao mesmo tempo. Assim, na coletânea, não existe nenhum valor absoluto. Tudo é relativo e móvel, tudo é engano, tudo é sonho, nada é aquilo que parece ${ }^{340}$, e, muitas vezes, a interpretação depende do narrador. A história da sogra não é o único duplo, há outros dentro da coletânea. Por exemplo, a história trágica sobre a busca de tesouro, em A noite na véspera do dia de Ivan Kupala, se repete, mas já com uma conotação cômica, em Um lugar encantado. A procura burlesca do caminho, em Uma noite de maio, se torna em uma perda do caminho terrível, cheia do horror místico, em A Terrível Vingança. Dentro da

\footnotetext{
${ }^{336}$ GÓGOL, 1976, tomo I, p. 57

${ }^{337}$ Idem, Ibidem, p. 68.

${ }^{338}$ Idem, Ibidem.

${ }^{339}$ Idem, Ibidem.

${ }^{340}$ GÓGOL, N. V. A Avenida Niévski. Trad. Arlete Cavaliere e Mário Francisco. São Paulo: Paz e Terra, 2002. p. 120.
} 
coletânea, não somente os episódios são conversíveis, mas também as próprias ideias sobre o bem e o mal, o sagrado e o maldito. Tal visão do mundo aproxima a coletânea do romance gótico, que duvidava de todos os valores estabelecidos.

Mais um narrador da coletânea é o cabeça, que três vezes tenta contar a história da sua viagem com a tzarina para Crimeia. A história nos ajuda a entender as fronteiras temporárias da novela.

A Carta Perdida - narrador popular. Em A Carta Perdida, o leitor de novo escuta a fala de Fomá Grigórievitch. Seu falecido avô agora é o herói da sua história. Assim como em A noite da véspera do dia de Ivan Kupala, o diácono adorna o seu discurso com várias digressões que retardam a ação. Algumas frases ou mesmo nomes são pronunciados apenas para criar um efeito cômico sonoro dentro do texto - por exemplo, os nomes do escrivão regimental: Viskriák, não é Viskriák, Motúzotchka, não é Motúzotchka, Golopútsek, não é Golopútsek... sei apenas que esse apelido esquisito começava de algum jeito curioso ${ }^{341}$. Esses nomes não existem e foram inventados pelo escritor explicitamente para causar riso nos leitores.

Como a ação se desenrola no passado distante, o mundo mágico entra em contato direto com o mundo cotidiano. As fronteiras entre a força impura e as pessoas, nessa novela, são praticamente dissolvidas - os dois mundos facilmente e livremente se cruzam. O poder da palavra é absoluto: basta só mencionar o diabo, e ele já aparece na história. O amigo novo do protagonista, o cossaco, ativa o fantástico, contando como ele vendeu sua alma ao diabo: Não preciso ocultar o meu segredo de vocês,-disse ele, de repente, olhando ao redor e cravando neles os seus olhos imóveis. - Vocês sabem que há muito tempo que a minha alma foi vendida ao espírito impuro $?^{342}$. É visível que ninguém dos heróis está surpreendido com essa declaração, porque Quem na sua vida não conheceu o espírito impuro? ${ }^{343}$

A narrativa do taberneiro serve para o herói como uma instrução. É um personagem auxiliar na história, porque ele é o único que sabe como entrar em contato com a força impura, um tipo de xamã que dá um conselho ao protagonista. A fala do taberneiro é uma estilização ao conto maravilhoso eslavo. São usadas repetições (siga pelo atalho, continua andando...), metáforas (os ciganos que saem dos seus covis para forjar ferro nas noites em que só as bruxas voam nos seus atiçadores), proibições mágicas (mas não vá na direção de

\footnotetext{
${ }^{341}$ GÓGOL, 2014, pp. 96-97.

${ }^{342}$ Idem, Ibidem, p. 98.

${ }^{343}$ Idem, Ibidem.
} 
onde vem o ruído), indicações indiretas aos objetos (só não se esqueça de encher os bolsos com aquilo para qual os bolsos são feitos) etc.

Perto da taberna tem uma curva à direita em direção à floresta. Você tem que estar pronto logo que começar a escurecer. Na floresta moram os ciganos que saem dos seus covis para forjar ferro nas noites em que só as bruxas voam nos seus atiçadores. Como eles fazem para viver de verdade não é da sua conta. Vai ter muito ruído na floresta, mas não vá na direção de onde vem o ruido; e surgirá na sua frente um atalho estreito. Passando uma árvore queimada, siga pelo atalho, continua andando... $O$ abrunheiro vai te arranhar, a densa aveleira irá obstruir o seu caminho - mas você deve continuar; e quando chegar a um pequeno rio, só então poderá parar. Ali você vai ver quem precisa; só não se esqueça de encher os bolsos com aquilo para qual os bolsos são feitos... Entenda que este bem é amado por ambos, diabos e pessoas ${ }^{344}$.

A narrativa do avô sobre a continuação da sua viagem à tzarina não é menos fantástica que o resto do texto. A tzarina estava numa camisola cinza novinha, de botas vermelhas $e$ comendo galúchkas de ouro ${ }^{345}$. Podemos ver esse episódio de dois pontos de vista. Por um lado, ele pode ser observado como um processo de uma criação de uma lenda. É provável que o cossaco realmente tivesse visitado a tzarina, mas o distanciamento temporal "apagou" os detalhes verdadeiros da sua viagem, e os narradores posteriores acrescentaram os episódios não menos extraordinários que o jogo de cartas com os diabos no inferno. Por outro lado, se considerar a novela como uma versão literária do conto maravilhoso, todos os episódios cabem no esquema explicado por Propp: a desgraça - o teste do herói - a volta triunfante e o encontro com a tzarina.

O sistema dos narradores cumpre várias funções importantes nas novelas gogolianas. Em relação ao gótico, os seus objetivos principais são, de um modo ou do outro, introduzir o fantástico no enredo cotidiano, preparar os heróis para a sua travessia ao outro mundo. Os procedimentos principais são o distanciamento temporal, com o processo constante da criação de uma lenda, e a "objetivação" do texto por meio dos vários níveis narrativos.

\footnotetext{
${ }^{344}$ GÓGOL, 2014, p. 100.

${ }^{345}$ Idem, Ibidem, p. 104.
} 


\title{
Oposição herói/vilão
}

\author{
$O$ efeito verdadeiro consiste em oposição nítida; a \\ beleza nunca é tão brilhante e visível como em \\ contraste $^{346}$.
}

(Gógol, Sobre a Arquitetura de hoje, 1831).

Uma das peculiaridades principais do romance gótico é o seu sistema de personagens. Diferentemente do romance de cavalaria ou romance de aventuras, com os quais tem conexões, o foco narrativo, no gótico, não é o herói, mas o vilão. A oposição herói/vilão consiste em dois elementos desiguais. $\mathrm{O}$ autor dá uma descrição mais detalhada da aparência e do caráter do antagonista da história que, geralmente, possui mais profundidade que o herói ou a heroína, as personagens que são virtuosas, mas, às vezes, unívocas. Paradoxalmente, podemos chamar um verdadeiro herói gótico um vilão, e um herói - um "anti-vilão", porque este realmente é "tudo o que o vilão não é". Por exemplo, se o autor menciona feiura pavorosa do vilão, o herói será descrito como muito bonito. Se o vilão é dirigido por suas paixões crueldade, cobiça, desonestidade, perfídia, perversão - , o herói é o oposto: nobre, honesto e justo.

Para o leitor, o vilão gótico, geralmente, permanece um enigma até o final da obra. Frequentemente, não sabemos o seu passado, os motivos das suas ações cruéis e podemos somente fazer nossas suposições sobre o seu comportamento. Com o descobrimento de alguns fatos da sua biografia, o leitor começa a vê-lo mais como uma vítima do que um criminoso. Suas ações desonestas são colocadas ao lado dos vícios horríveis das pessoas. O vilão não é pior, e, de vez em quando, até é melhor que a sociedade que o cerca. Em Gógol, o exemplo mais evidente do vilão gótico é o feiticeiro de $A$ Terrível Vingança: embora um assassino, um traídor da família e da pátria, quase um Anticristo, no final da novela, ele é visto como uma vítima do destino.

O vilão gótico representa um desafio para a sociedade hipócrita que foi engendrada pela época do Iluminismo, com suas constantes restrições sociais e psicológicas. Protestando contra as instituições e os valores morais contemporâneos que oprimiam a liberdade humana, os autores góticos sentiam uma certa admiração pelas personalidades individuais dos tiranos. Solitário, sombrio, misterioso e melancólico, o vilão gótico, posteriormente, deu origem ao

\footnotetext{
${ }^{346}$ GÓGOL,1976, tomo VI, p. 76.
} 
herói byroniano, que, por sua vez, gerou, na Rússia, uma galeria de "homens supérfluos", incluindo Eugênio Oneguin.

Frequentemente uma pessoa de origem nobre, o vilão gótico é corrompido pelos vícios e pelas paixões que, de modo constante, dirigem o seu comportamento. Segundo Simpson, "dilemas frustrantes emocionais e sexuais [...] tendem a envolver o herói gótico, que também sofre com a sexualidade oprimida ${ }^{347}$ ". Pessoa resoluta e poderosa, ele está pronto para superar qualquer obstáculo no seu caminho. Não raramente é sensual e lascivo, tem uma atração forte pelas mulheres bonitas, às vezes, pelas suas parentes: filhas, irmãs, sobrinhas etc. O relacionamento incestuoso executa, no enredo gótico, uma função de maximizar o protesto contra a sociedade. No caso de uma vilã, ela é caracterizada pela sexualidade libertina, completamente inapropriada para qualquer heroína "positiva" da época. Sexualidade aberrante, segundo Bayer-Berenbaum, é não raramente associada, na literatura gótica, às pessoas que possuem poderes sobrenaturais, como bruxas e vampiros ${ }^{348}$.

Uma das características marcantes da aparência do vilão/vilã é o olhar forte e cativante. Fisher salienta que o olhar do vilão possui uma "habilidade de penetrar os segredos mais íntimos da sua vítima. Essa feição está vinculada ao Mau-Olhado, no folclore, que tem poderosos efeitos mágicos, hipnóticos ${ }^{349 "}$ ". Em Gógol, o exemplo do tema de "mau-olhado", é o vilão Bassavriuk de A Noite na véspera do dia de Ivan Kupala: os camponeses tentam não aceitar os seus presentes amaldiçoados, mas não conseguem resistir quando ele lança o olhar severo.

Em Noites, o vilão, praticamente em todas as novelas, é um portador da força impura um feiticeiro, um diabo, uma bruxa. A aparência dos vilãos varia de uma novela para outra, mas é notável o efeito de hiperbolização, usado pelo escritor em abundância: o vilão pode ser grotescamente feio, como o feiticeiro de $A$ Terrível Vingança, ou extremamente bonito, como a bruxa de Uma noite de maio. Sua beleza, porém, é diferente da beleza das heroínas, porque é privada da vida, é uma beleza morta, demoníaca. Os tipos do vilão gótico, nas novelas ucranianas, são: um vilão-vítima, de $A$ Terrível Vingança, um vilão-tentador, de $A$ noite da véspera do dia de Ivan Kupala, uma mulher-vilã de Uma noite de maio, ou a moça afogadaum tipo raro para a literatura russa e, por isso, ainda mais interessante. Finalmente, a "tribo diabólica", de A Carta Perdida, é uma imagem coletiva do vilão, uma certa caricatura da

\footnotetext{
347 SIMPSON, 1986, p. 12.

${ }^{348}$ BAYER-BERENBAUM, 1982, p. 42.

${ }^{349}$ FISHER, 2002, p. 76.
} 
sociedade dos cossacos na granja, porque se comporta do mesmo modo como os habitantes de Dikanka: come toucinho, joga cartas e bebe vodca.

O herói, no romance gótico, é geralmente alguém que foi escolhido pelas forças misteriosas para reparar alguma injustiça que existe no mundo. Muitas vezes, com ele, é introduzido, na obra, o tema de uma maldição familiar - o herói é responsável pelos crimes dos seus antecedentes. Para o herói faz-se muito difícil, às vezes, até impossível, lutar com o vilão - a prova exige todas as suas forças, tanto físicas quanto espirituais. O dramatismo da situação é reforçado com a solidão do herói: ele está lutando sozinho contra a força maligna e pode confiar somente em si mesmo, não tem nem amigos nem família para lhe ajudar nos momentos difíceis.

Os protagonistas, em Noites, como Danilo, de A Terrível Vingança, Petró, de A noite da véspera do dia de Ivan Kupala, Levkó, de Uma noite de maio, o cossaco sem nome, de A Carta Perdida, estão sozinhos em sua luta contra o mal. São separados, parcialmente ou por completo, das suas famílias, não conhecem o pai ou a mãe. É, constantemente, sublinhado o tema da ausência da família e o desejo dos heróis de criá-la. Segundo Gontcharov, "o amor e o casamento/família são os valores únicos que as personagens masculinas tentam obter, superando todos os obstáculos ${ }^{350}$,. Os heróis, geralmente, são mais ativos que as heroínas, que, em Gógol, permanecem em uma posição de espera passiva, porque estão dependentes de um pai severo (Katerina, de $A$ Terrível Vingança, Pidorka, de $A$ noite da véspera do dia de Ivan Kupala) ou de uma madrasta/mãe (pánnotchka e Ganna, de Uma noite de maio). Para conseguir a mão e o coração da heroína, o herói precisa entrar em contato com o outro mundo, provar que ele é digno da mulher, lutar com o mal, executando algumas ações mágicas, como, por exemplo, acontece com Levkó, em Uma noite de maio, quando ele ajuda a adivinhar a bruxa em um jogo de corvo e assim alivia a alma da pánnotchka.

Diferentemente do romance gótico, na obra gogoliana, o resultado da luta contra o mal nem sempre está nas mãos do herói: muitas vezes, eles são vencidos pelo vilão. Das quatro novelas analisadas por nós, duas têm um final infeliz. Afirma Mann que "o afastamento gogoliano do princípio carnavalesco manifestou-se de um modo mais forte em sua atitude a morte ${ }^{351}$ ", que, nas obras do escritor, perde o seu caráter ambivalente, característico para o pensamento medieval.

O conflito principal, porém, acontece entre o vilão e a heroína. Uma oposição entre o homem e a mulher, em Noites, é um tipo de classificador universal que sexualiza o mundo,

\footnotetext{
${ }^{350}$ GONTCHAROV, 1993, p. 4.

${ }^{351}$ MANN, 1978, p. 28
} 
oposição esta que também pode ser vista como uma variação do tema "próprio/alheio"352. A vitimização constante das mulheres é típica da ficção gótica. Em personagens femininas, destacam-se tais feições de caráter como feminilidade, fraqueza, passividade e sensibilidade extremas - são as vítimas perfeitas para o vilão. Bayer-Berenbaum explica que "a feminilidade idealizada [...] é extremamente comum no romance gótico e, geralmente, funciona mais como um fundo para a crueldade do que uma descrição convincente do comportamento $^{353}$ ”. Por falar em aparência, as heroínas são, via de regra, bonitas, mas a sua beleza possui também um aspecto doentio: são pálidas e magras, às vezes, até se pode dizer que estão à beira da morte, uma peculiaridade especialmente visível, por exemplo, nos contos de Edgar Allan Poe e, por acaso, em Katerina, de A Terrível Vingança, de Gógol. Não raramente, essas personagens cumprem um papel complementar no enredo - elas são “donzelas em perigo”, que esperam a salvação pelo herói.

Algumas personagens femininas, em Gógol, são semelhantes às belas heroínas góticas, embora não sejam plenamente desenvolvidas pelo escritor no plano psicológico. Aqui não falamos de todas as heroínas gogolianas - no mundo artístico do escritor, existem vários tipos de mulheres, inclusive a figura salvadora da mãe (em Diário de um louco), as mulheres fúteis da sociedade (por exemplo, Anna Andreevna e Maria Antónovna, de Inspetor Geral) e outras personagens peculiares. Na opinião de Bélyi, em geral, as mulheres gogolianas não são mais do que uma máscara. Somente algumas personalidades, que geram algo "diabolicamente doce" nos heróis, são destacadas do cotidiano, como a pánnotchka, de Viy, a moça afogada, de Uma noite de maio, Katerina, de A Terrível Vingança. As outras não possuem movimentos da alma, são bonecas nos vestidos bonitos, esteriótipos, como, por exemplo, Osana, de A noite de natal $^{354}$.

Destacamos aqui somente as heroínas às quais se podem referir como as beldades: a este grupo bastante grande, pertencem Katerina, de A Terrivel Vingança, Pidorka, de A noite da véspera do dia de Ivan Kupala, a pánnotchka, de Uma noite de maio, a bruxa de Viy. Todas elas são extremamente bonitas, praticamente, não agem no enredo e, muitas vezes, não parecem feitas de carne e osso ${ }^{355}$.

As descrições de beleza, em Gógol, nunca são calmas, neutras, mas sempre hiperbolizadas, mostradas em seu extremo, como todos os fenômenos na poética gogoliana,

\footnotetext{
${ }^{352}$ GONTCHAROV, 1993, p. 6.

${ }^{353}$ BAYER-BERENBAUM, 1982, p. 24.

${ }^{354}$ BELYI, 1934, p. 146

355 Observação feita em CAVALIERE, 2009, p. 96.
} 
segundo Rózanov ${ }^{356}$. Vários críticos, por exemplo, S. Botcharov, mencionam que "Gógol parece um artista muito arcaico especialmente como um retratista de beleza: na parte já tardia do século XIX, ele, ao que parece, segue os clichés retóricos seculares ${ }^{357}$,. O pesquisador explica que as mulheres bonitas, em Gógol, seguem o mesmo padrão de descrição. Em primeiro lugar, possuem uma palidez descomunal do rosto, semelhante à neve, - uma referência ao seu caráter celeste, mas que, ao mesmo tempo, pode ser vista como um símbolo de frieza da personagem. Outros dois detalhes importantes são os cílios longos, que não por acaso parecem flechas - elas podem "ferir" uma pessoa descuidada - , e o sorriso que incendeia a alma - são as feições dramáticas, perigosas.

Esse padrão específico de beleza foi estabelecido por Gógol já no primeiro ensaio que tinha publicado, em 1831, sob o nome A Mulher. O autor, aos 22 anos, explicou a sua visão do objetivo da mulher no mundo. No ensaio em questão, a mulher foi chamada a língua dos deuses, e também uma ideia imortal, poesia e pensamento - assim o escritor via a missão feminina. Faz-se necessário citar alguns trechos desse texto curto, para compreender melhor a visão gogoliana sobre o papel da mulher. Para Gógol, a mulher é a ideia alta de beleza divina na terra, cujo objetivo é incentivar os homens às boas ações, inspirá-los a fazer o mundo melhor. Por isso, a mulher, em sua encarnação ideal, é alheia ao mundano, carnal. Ela representa uma quintessência de pureza e inocência. Assim Gógol descreve Alcinoia, a heroína de A Mulher: Uma mão de mármore, através da qual transpareciam as veias azuis, cheias de ambrósia celeste, pairava livremente no ar ${ }^{358, "}$ ou também: Parecia que o éter fino e claro, em que se banham os habitantes do céu, pelo que percorrem as chamas rosas e azuis [...] parecia que este éter se tornou visivel e estava em sua frente, benzendo e deificando a forma maravilhosa do ser humano ${ }^{359}$.

Como se pode observar, a beleza, em Gógol, é específica: como neve, ela brilha, mas não aquece. Como um relâmpago, ela pode iluminar o caminho do homem ou destruí-lo com seu poder. De qualquer modo, é possível dizer que o papel das personagens femininas se estende além das funções da heroína típica gótica. Diferentemente das personagens de Ann Radcliffe, as heroínas gogolianas podem cumprir um papel feliz ou fatal para os heróis.

A oposição gótica entre o herói/heroína e o vilão/vilã é visível em todas as novelas aqui analisadas. O feiticeiro, de $A$ Terrível Vingança, é, possivelmente, a figura mais estudada

\footnotetext{
${ }^{356}$ RÓZANOV, V. V. Legenda o velikom inkvizitore F. M. Dostoévskovo. Moskvá: 1996, p. 148.

${ }^{357}$ BOTCHAROV, Sergei. “Krassávitsa mira”. Jénskaia krassota u Gógolia. In MANN (Org.), 2003, p. 15.

${ }^{358}$ GÓGOL, 1976, tomo 6, p. 10.

${ }^{359}$ Idem, Ibidem.
} 
da obra gogoliana em relação ao gótico ${ }^{360}$. Como mencionamos antes, nessa novela, o vilão é, ao mesmo tempo, uma vítima. Ele aparece no texto em duas hipóstases: como o pai de Katerina, no mundo real, e como o feiticeiro, no mundo fantástico. Por algum tempo, as duas imagens na obra coexistem e se apresentam desdobradas, acentuando a ideia de paralelismo e inversão simultâneos. Os episódios paralelos, nos dois espaços da obra, dão volume ao caráter e mostram detalhadamente o comportamento do feiticeiro. Por exemplo, ambos, o pai de Katerina e o feiticeiro, são vistos como os visitantes funestos: o primeiro, no casamento de esaul Gorobietz. O segundo, na própria família: durante vinte e um anos estivera desaparecido sem dar notícias e voltara para junto de sua filha quando esta já estava casada e já dera à luz o filho ${ }^{361}$. Isso indica que ele não conversava com a filha há mais de vinte anos e perdeu completamente a conexão com ela; apareceu em sua casa, de repente, sem convite.

Em ambos os espaços, é destacada a paixão incestuosa do vilão por Katerina. No mundo mágico, o feiticeiro tenta seduzir a alma da sua filha, dizendo: olha para mim, Katerina, olha como sou belo! As pessoas mentem quando dizem que sou feio. Eu serei para ti um excelente marido. Vê com que olhos eu te olho! $!^{362}$. O pai de Katerina lança o mesmo olhar para a sua filha no mundo real: Somente por ti, filha minha, perdô! - responde ele, beijando-a, e seus olhos brilham de um brilho assombrado ${ }^{363}$. Parece que o feiticeiro possui algum poder misterioso sobre a sua filha: ele sabe evocar a sua alma e conversar com ela; também, no mundo real, é Katerina que o deixa escapar da prisão. O feiticeiro é o traidor em ambas as existências: no mundo real, ele é o traidor da pátria: Não é por magia e nem por pactos contra Deus que o feiticeiro está preso no porão profundo. [...] Ele está lá por uma traição secreta, por sua confabulação com inimigos da terra russa ortodoxa, e por vender o povo ucraniano aos católicos ${ }^{364}$. No mundo mágico, ele é o traidor de Deus, um grande pecador cujos crimes não podem ser perdoados nem pelas forças divinas.

Mas, apesar dessa dupla existência, a imagem do feiticeiro é íntegra. A melhor palavra com que se pode decrevê-lo é forasteiro, uma pessoa completamente alheia, não somente para a sociedade dos cossacos, mas para o mundo inteiro, sozinha no universo. Por isso, na descrição do personagem, prevalecem os dois princípios: da negação e da exclusão.

\footnotetext{
${ }^{360}$ Ver especialmente os artigos da antologia TAMÁRTCHENKO, N., ZÚSSEVA, V., MÁLKINA, V. et. al., 2008.

${ }^{361}$ GÓGOL, 1990, p. 44.

362 Idem, Ibidem, p. 54.

${ }^{363}$ Idem, Ibidem, p. 53.

${ }^{364}$ Idem, Ibidem, p. 62.
} 
O primeiro princípio é melhor evidenciado já nas primeiras cenas da novela, quando o pai de Katerina não aparece no casamento do filho de esaul Gorobetz: ainda mais se admiravam por não ter chegado com ela o velho pai [...] Ele, certamente, contaria muitos fatos prodigiosos. E como deixar de contar, tendo estado tanto tempo em terra estranha! Lá as coisas não são assim, as pessoas também não, e não há igrejas cristãs ${ }^{365}$. A pessoa que estava ausente por muito tempo da pátria não estava presente nas festividades, o que desde o início parece suspeito aos convidados.

O conflito entre Danilo e o sogro começa com o comportamento estranho do último, que é visto como "não do cossaco". São apresentados os imperativos do comportamento do cossaco verdadeiro, e qualquer afastamento dessas regras, não escritas, é visto como uma transgressão: Um cossaco, graças a Deus, não tem medo nem de diabos, nem de padres poloneses. Muito proveito teríamos se nos puséssemos a ouvir as esposas. Não é isso, rapazes? Nossas esposas são o cachimbo e o sabre afiado também! ${ }^{366}$. O sogro, que é bem diferente desse padrão, é julgado e acusado por Danilo:

Ouve, Katerina, parece-me que o teu pai não quer viver em harmonia conosco. Chegou sombrio, severo, como se estivesse aborrecido... Bem, se está descontente, para que veio aqui? Não quis beber pela liberdade dos cossacos! Nem embalou em seus braços o pequeno. De início, eu queria confiar a ele tudo o que está no meu coração, mas algo não me deixou e a conversa ficou engasgada. Não, ele não tem coração de cossaco ${ }^{367}$.

O princípio da negação se intensifica, junto ao mistério que cerca o personagem. $\mathrm{O}$ aparecimento inesperado do feiticeiro no casamento é destacado também através da negação: Quem fosse, ninguém sabia ${ }^{368}$. Não por acaso, Danilo diz sobre o sogro: Eu até agora não consegui decifrá-lo ${ }^{369}$.

O sogro não bebe álcool - uma peculiaridade bem estranha para a consciência russa cultural: Não quis beber hidromel! Estás ouvindo Katerina, não quis beber o hidromel que arranquei dos judeus de Brest. [...] Tampouco bebe aguardente. Que desperdício. Eu acho,

\footnotetext{
365 GÓGOL, 1990, p. 44.

${ }^{366}$ Idem, Ibidem, p. 47.

${ }^{367}$ Idem, Ibidem, p. 49.

${ }^{368}$ Idem, Ibidem, p. 44.

${ }^{369}$ Idem, Ibidem, p. 54.
} 
pani Katerina, que ele nem mesmo crê em nosso senhor ${ }^{370}$. Ele também não come a comida típica dos cossacos: Eu não gosto destes galúchki! [...] Eu não gosto de carne de porco! ${ }^{371}$

Andrei Bélyi, analisando essas cenas, chega à conclusão de que o princípio de negação é o procedimento mais importante na representação do vilão: “O feiticeiro é descrito por meio de partículas 'não, ${ }^{372, " . ~ E m ~ g e r a l, ~ a ~ a v a l i a c ̧ a ̃ o ~ d e ~ B e ́ l y i ~ e ́, ~ n o ~ m i ́ n i m o, ~ s u b j e t i v a: ~ o ~ e s c r i t o r ~ v e ̂, ~}$ no feiticeiro, um herói que não foi entendido pela sociedade arcaica. Segundo o simbolista, o feiticeiro é estrangeiro, iluminista, adepto do progresso, alquimista e visionário: "nós temos direito de pensar: os signos 'com uma inscrição nem russa nem polonesa' são escritos... em francês ou alemão; a água preta é um café; o feiticeiro é vegetariano, ele estuda astronomia e faz experimentos ${ }^{373}$ ". Se seguir esse modo do raciocínio, não é o feiticeiro que é terrível, mas a sociedade, o "horrível monstro do clã" que o nega. A ideia de Bélyi parece interessante, mas a interpretação do escritor, possivelmente, seja muito livre.

Provavelmente, para a caracterízação do feiticeiro, seja mais produtivo falar sobre o princípio da exclusão: o sogro/feiticeiro possui muitas feições completamente originais, características só para ele. Assim ele pode ser visto não somente como o "não cossaco", mas também como alguém diferente de todo mundo, "ninguém outro". Por exemplo, quando Danilo observa as armas no castelo do feiticeiro, ele percebe que não as usam nem os turcos, nem os crimeus, nem os cristãos e nem o bravo povo sueco ${ }^{374}$ - quer dizer, ninguém que ele conhece.

O princípio da exclusão é visto já na aparência do feiticeiro, que não é somente oposta aos outros, mas também é excepcional, extraordinária: o nariz cresceu e caiu para o lado; de castanhos, os olhos tornaram-se verdes e saltados, os lábios ficaram azuis, o queixo começou a tremer e afilou em ponta como uma lança, da boca surgiu uma presa, atrás da cabeça se elevou uma corcunda ${ }^{375}$. A feiura grotesca é característica para o vilão gótico, assim como as feições ferinas, para sublinhar o caráter pervertido e cruel da personagem dirigida por seus vícios. Não por acaso, o feiticeiro é comparado a um lobo: soltando um silvo e rangendo os dentes como um lobo, o velho prodigioso desapareceu ${ }^{376}$. Afirma Botting que as representações do vício como um monstro eram típicas para o romance gótico desde o século XVIII: “O termo 'monstro' foi aplicado nas opiniões estéticas às obras que eram não naturais

\footnotetext{
${ }^{370}$ GÓGOL, 1990, p. 54.

${ }^{371}$ Idem, Ibidem, p. 55.

${ }^{372}$ BÉLYI, 1934, p. 57.

${ }^{373}$ BELYI, 2009, p. 343.

${ }^{374}$ GÓGOL, op. cit., pp. 57-58.

${ }^{375}$ Idem, Ibidem, p. 45

${ }^{376}$ Idem, Ibidem.
} 
e deformadas, que desviavam ou da regularidade atribuída à vida e natureza, ou da simetria e proporção valorizadas em qualquer forma de representação ${ }^{377, "}$.

O sogro come uma comida muito esquisita, que ninguém outro come: Comeu apenas uma lemíchka com leite e, ao invés de vodca, sorveu algo parecido com uma água preta do cantil que estava em seu peito ${ }^{378}$. Segundo Mann, a combinação desses pratos é muito estranha: por um lado, lemíchka, um tipo de mingau bem ralo, é uma comida simples popular. Por outro lado, alguma água preta completamente desconhecida ${ }^{379}$.

O sogro usa a roupa diferente também, chegando à casa de Danilo com um cachimbo estranho entre os dentes ${ }^{380}$. No castelo, o feiticeiro põe um estranho gorro, todo rabiscado com uma inscrição nem russa nem polonesa ${ }^{381}$. A pesquisadora italiana, Cinzia de Lotto, comenta que, em Gógol, a roupa tem um papel ativo e proeminente: "Com a influência da roupa acontece uma transformação do personagem - uma mudança de roupa cumpre uma função da mudança como uma definição da essência existencial ${ }^{382, \%}$. Tirando a sua roupa, o herói tira uma máscara. Não por acaso, a figura do feiticeiro na novela se transforma junto a sua roupa - um tema barroco de uma mudança completa da pessoa com a nova máscara: Danilo pôs-se a observá-lo e viu que já não vestia o jupan vermelho; ao invés disso, viu bombachas como as que usam os turcos; presas ao cinto, as pistolas [...] e o rosto começou a se transformar ${ }^{383}$.

Um procedimento específico da exclusão do feiticeiro é a zombaria, a força destruidora do riso na novela. A zombaria pode ser verdadeira ou somente parecer à vítima, mas "o zombado é excluido da comunidade, entre ele e os outros surge uma barreira intransitável. A zombaria está no limiar da perseguição ${ }^{384}$ ". O riso aparece na novela sempre como um modo de humilhação do personagem. Nada mais assusta o feiticeiro como o riso: parece que sempre imaginava que todos riam dele. E, se por acaso encontrava alguém numa noite escura que abrisse a boca, sempre lhe parecia mostrar os dentes e rir dele. No dia seguinte, a pessoa era encontrada morta ${ }^{385}$. No final, o riso é mencionado três vezes: o riso do cavalo (imaginado), o riso do monge e o riso do bogatir, que representam a rejeição total

\footnotetext{
${ }^{377}$ BOTTING, 1996, p. 98.

${ }^{378}$ GÓGOL, 1990, p.58.

${ }^{379}$ MANN, 1978, pp. 45-46.

${ }^{380}$ GÓGOL, op. cit., p. 50.

${ }^{381}$ Idem, Ibidem, p. 58.

382 DE LOTTO, CINZIA. Gógol': odéjda i moda. In MANN (Org.), 2003, p. 80.

${ }^{383}$ GÓGOL, op. cit., p. 58.

${ }^{384}$ MANN, 1978, p. 46

${ }^{385}$ GÓGOL, op. cit., p. 46.
} 
do herói: pelas pessoas (monge), pelas forças de natureza (cavalo) e pelas forças divinas (bogatir).

A lenda de Petró e Ivan aprofunda a nossa visão do vilão. É introduzido o tema da maldição familiar: Que o último do clã seja mau, como nunca existiu outro no mundo! E que para cada um dos seus crimes, nem os seus avós e nem os bisavós encontrem repouso nas tumbas, $e$, sofrendo um tormento mais amargo ${ }^{386}$. Não há um episódio típico da venda da alma ao diabo, do começo do caminho de um grande pecador. Estamos numa situação paradoxal: por um lado, o vilão representa todo o mal do universo. Por outro lado, o feiticeiro não é responsável por seus crimes, e o criador do mal é a primeira vítima do universo, o morto Ivan. $\mathrm{O}$ executor torna-se uma vítima, e a vítima, um executor. $\mathrm{O}$ círculo se fechou.

Provavelmente a questão mais importante para o entendimento da imagem do feiticeiro é a questão da sua culpa. A complexidade consiste na incompatibilidade dos planos subjetivos do narrador e das personagens. Sem dúvida, para Katerina e Danilo, o feiticeiro é um portador de má vontade: eles acham que todos os feitos horríveis são resultados das intenções e dos interesses do velho. Mas o vilão não é onipotente. Seu poder é limitado por outra força, muito mais poderosa e muito mais impiedosa.

A narrativa mitológica põe limitações à culpa do feiticeiro. De repente, descobrimos que o maior pecador do mundo não é independente em seu arbítrio e até na compreensão dos seus desejos: "O estado do espírito do feiticeiro desenvolve-se fora das coordenadas do bem e do mal, do crime e do arrependimento 387 ". Ele não sabe as razões para os seus crimes, em sua atrocidade não há nem lógica nem senso comum: Algo queimava-o e ele queria pisotear tudo com seu cavalo, pegar toda a terra de Kiev até Gálitch com todas as pessoas, com todas as criaturas, e afundá-la no Mar Negro. Mas não era por maldade que ele queria fazê-lo; não, nem ele mesmo sabia o porquê $\hat{e}^{388}$. Como é possível observar, a imagem do feiticeiro é uma das mais complexas nas novelas: um vilão e uma vítima, o pecador que procura salvação, a fonte do mal e o objeto do destino divino. Ele representa a síntese do contraste unido na mesma pessoa.

O herói de A Terrível Vingança, Danilo, cumpre, no enredo, um papel complementar. A primeira vista, Danilo é um antípoda do feiticeiro: um cossaco, patriota, representante de um coletivo, defensor da família. A preocupação pela pátria é um dos aspectos marcantes da sua personalidade. Diz: Não há ordem na Ucrânia: os coronéis e os esauls brigam entre si

\footnotetext{
${ }^{386}$ GÓGOL, 1990, p. 83.

${ }^{387}$ MANN, 1978, p. 56.

${ }^{388}$ GÓGOL, op. cit., pp. 79-80.
} 
como cães. Não há a cabeça de um chefe sobre todos. Nossa nobreza habituou-se aos costumes polacos; adquiriu malícia... vendeu a alma, aceitando a união ${ }^{389}$. Enquanto o feiticeiro pensa somente em própria felicidade, Danilo pensa frequentemente em termos da felicidade coletiva. Ele é valente: Eu varrerei esse ninho do diabo assim que correr o rumor de que nele há algum covil. Queimarei o velho feiticeiro de tal modo que os corvos nada poderão rancar $^{390}$.

É possível perceber que, até o final, Danilo não compreende o tamanho do mal com que está lutando. Para ele, o feiticeiro não é mais difícil para vencer que qualquer polaco ou turco. O erro trágico do cossaco é uma tentativa de vencer a magia com uma arma simples, e a atitude quase cavaleiresca com o seu inimigo: ele coloca o pai de Katerina na prisão, para julgá-lo, e o velho sogro consegue escapar. Depois Danilo é assassinado pelo inimigo na batalha inesperada entre os polacos e os cossacos.

Danilo possui muitos hábitos característicos de um cossaco: ele gosta de comer e beber bem, gosta das festas com seus amigos. Depois do almoço pesado, ele dorme um sono também pesado de bogatir. Um guerreiro experiente, ele nunca perde o seu próprio lucro. Por isso, em sua casa, há tantos mosquetes, preciosos sabres, arcabuzes e lanças que, por bem ou por mal, vieram dos tártaros, turcos e polacos ${ }^{391}$.

Mas é curioso observar que, apesar do fato de Danilo ser um herói verdadeiro, ele nem sempre se comporta de acordo com as leis dos cossacos. Ele sente medo das forças impuras: Também pan Danilo parou: o medo e o frio penetraram nas veias dos $\operatorname{cossacos}^{392}$. Para Danilo, esse medo é uma fraqueza que não consegue superar: É terrivel, terrível! - diz ele para si, sentindo vacilar seu coração de guerreiro ${ }^{393}$. O medo faz o herói vulnerável ao mal, como também acontece nas outras novelas ucranianas. Em Viy, por exemplo, um dos heróis cômicos assim explica a morte inesperada do protagonista: [...] eu sei por que ele morreu: morreu porque teve medo. Se não tivesse medo, a bruxa não poderia ter feito nada contra ele $e^{394}$.

Danilo também é diferente do cossaco "ideal” em relação à família. Como já foi mencionado, o cossaco típico valoriza, em primeiro lugar, a liberdade e os amigos,

\footnotetext{
${ }^{389}$ GÓGOL, 1990, p. 67.

${ }^{390}$ Idem, Ibidem, p. 47.

${ }^{391}$ Idem, Ibidem, p. 50.

392 Idem, Ibidem, p. 48.

${ }^{393}$ Idem, Ibidem, p. 60.

${ }^{394}$ GÓGOL, 2010, p. 207.
} 
o cachimbo e o sabre afiado ${ }^{395}$. Mas, apesar de dizer que não ama a sua mulher, Danilo é apaixonado por Katerina, é carinhoso com ela e com seu pequeno filho: Preocupado, Burul'bach olhou para sua jovem esposa, que, assustada, embalava nos braços a criança que gritava; apertou-a contra o coração e beijou-a na testa ${ }^{396}$. A pátria deveria ser a única mulher na sua vida, mas ele continuava a adorar a sua esposa, ainda a filha de um traidor. Se Danilo fosse um verdadeiro representante da consciência arcaica, com suas leis da responsabilidade coletiva de todos os parentes pelos crimes dos antecedentes, então o herói deveria ter abandonado a sua mulher. Na realidade arcaica, não existe uma pessoa, e todos os filhos são responsáveis pelos crimes dos pais, porque o clã é algo indivisível. Então, quando Danilo resolveu permanecer ao lado da sua mulher, ele, parcialmente, tornou-se uma parte da família dos antepassados malditos do feiticeiro, prontos a se vender por qualquer dinheito a Satanás, com a alma e com os jupans esfarrapados ${ }^{397}$.

A imagem de Danilo mostra como são anti-humanos as leis do clã, como, por causa delas, é destruída a família inteira, como sofrem as pessoas. "A liberdade do cossaco" é a liberdade coletiva, que exclui qualquer vontade individual. O cossaco "ideal" tem coração de pedra, é incapaz de sentir a dor do outro, incapaz de perdoar. É especialmente visível quando Danilo está sofrendo por ter agido mal e não como cossaco, em pedir perdão sem ser culpado $^{398}$. Parece que Gógol, constantemente, mostra os lados fracos da ideologia arcaica, mostra a sua crueldade. Pois, se as pessoas vivessem de acordo com essas regras, o mundo já se afogaria em sangue. Na escolha de Danilo a favor da sua mulher, há um certo heroísmo, manifesta-se o seu sentimento profundo por Katerina. Ele próprio entende isso quando diz: $\mathrm{Se}$ soubesse que tinhas um pai assim, não teria casado contigo; eu teria te abandonado e não teria recebido em minha alma o pecado de ter parentesco com a casta de um Anticristo ${ }^{399}$. Mas ele reconhece em Katerina uma personalidade independente, e não só a filha do feiticieiro: eu agora te conheço e não te abandonarei por nada ${ }^{400}$.

A ação individual de Danilo o aproxima, inesperadamente, do sogro/feiticeiro. Se observar com mais atenção, eles têm mais em comum do que diferenças. Ambos os heróis moram longe da sociedade: o feiticeiro, completamente sozinho em seu castelo, Danilo - em uma casa que está entre duas montanhas no vale que desce para o Dniepr: Atrás dele há ainda

\footnotetext{
395 GÓGOL, 1990, p. 47.

${ }^{396}$ Idem, Ibidem, p. 48.

${ }^{397}$ Idem, Ibidem, p. 47.

${ }^{398}$ Idem, Ibidem, p. 53.

${ }^{399}$ Idem, Ibidem, p. 61.

${ }^{400}$ Idem, Ibidem.
} 
outra montanha, e depois o campo, onde mesmo que se ande cem verstas jamais se encontrará um cossaco sequer ${ }^{401}$. Ambos, Danilo e o sogro, são pessoas conflitantes. É Danilo que começa uma briga, dizendo as palavras ofensivas: já há tempo deixei de ser um daqueles a quem as bábas trocam as fraldas. [...] Sei como segurar nas mãos um sabre afiado. E ainda sei fazer mais alguma coisa... sei também não prestar contas a ninguém daquilo que faço ${ }^{402}$. Ambos são guerreiros bons, o que é visto já na sua primeira colisão em casa: Com força igual, lutam terriveis cossacos, nem um nem outro está vencendo ${ }^{403}$. Por isso, quando falamos em oposição herói/vilão, nessa novela, falamos de uma luta de dois indivíduos fortes.

Uma análise breve da imagem de Danilo mostra uma complicação e um aprofundamento do herói gótico. Por um lado, é um personagem simples, em alguns momentos até primitivo, não é acostumado a refletir sobre a vida. Por outro lado, é um herói que luta moralmente para se livrar das correntes sociais e até religiosas que atrapalham sua felicidade. No seu destino, Gógol mostra que a sentença divina não reconhece a misericórdia, não considera possível uma transição do princípio coletivo ao princípio individual, enquanto o tempo, o seu fluxo e as mudanças sociais se manifestam no mundo todos os dias.

Provavelmente o conflito entre Katerina e o feiticeiro seja ainda mais interessante para o compreendimento dos traços góticos na novela, com a introdução dos temas do incesto e da traição. Katerina tem feições em comum com as personagens femininas de Walpole, Radcliffe e Maturin. Ela é extremamente bonita, a sua beleza é brilhante: Maravilhavam-se os convidados com o rosto branco de pani Katerina, suas sobrancelhas negras como veludo alemão, e a elegante saia de lã azul ${ }^{404}$. Katerina é uma boa esposa e dona de casa, ela é doce, não guarda rancor, como uma pomba ${ }^{405}$. Ela é extremamente sensível. A mulher é uma das primeiras personagens que começa a se preocupar com o feiticeiro, pensar sobre o seu destino, sentir a aproximação da desgraça com o seu aparecimento: Um encontro com ele nada de bom me pressagia... ${ }^{406}$. Ela, com sua alma pura e inocente, começa a ver os sonhos proféticos que revelam que o seu pai e o feiticeiro são a mesma pessoa.

Assim como o sogro/feiticeiro, Katerina possui uma existência dupla - física e espiritual. É diferente do seu marido, que não faz nenhuma travessia para outro mundo - um

\footnotetext{
${ }^{401}$ GÓGOL, 1990, p. 49.

${ }^{402}$ Idem, Ibidem, p. 51.

${ }^{403}$ Idem, Ibidem, p. 52.

${ }^{404}$ Idem, Ibidem, p. 44.

${ }^{405}$ Idem, Ibidem, 1990, p. 62.

${ }^{406}$ Idem, Ibidem, p. 47.
} 
detalhe que nos faz pensar que o conflito principal deve ser entre Katerina e o seu pai. No mundo dos sonhos, Katerina é aérea: e pareceu a pan Danilo que a nuvem não era uma nuvem, mas sim uma mulher; mas de que era ela feita? Seria feita do ar? E como poderia estar de pé sem tocar o chão, sem apoiar-se em nada e, através dela, passar a luz rosada e refletirem-se na parede os traços? ${ }^{407}$. A imagem de Katerina-nuvem traz associações com o anjo, porque, na iconogafia comum, os anjos têm uma auréola e uma beleza delicada, emanando forte brilho.

Katerina sofre, dolorosamente, pelo conflito do seu pai e marido, e, nesse aspecto da sua personalidade, surge o tema do incesto, muito importante para o romance gótico e para Noites em particular. Segundo o pesquisador inglês Gary Cox, os relacionamentos indevidamente próximos entre os pais e os filhos são o "motor" principal dos enredos das novelas ucranianas: "Em muitas dessas histórias, o conflito dramático inclui uma revolta dos jovens contra essa estrutura familiar fechada, contra o pai tirânico ou até incestuoso ${ }^{408}$ ". No início da colisão dos heróis, é difícil perceber que lado Katerina toma: O coração de Katerina está para se desfazer em pedaços. [...] - Não, não suporto, não suporto... Já não será que seu sangue escarlate jorra como uma fonte do corpo branco? Será que meu amado desfalece agora enquanto eu estou aqui deitada ${ }^{409}$. O que parece curioso, nessa cena, é que a mulher não diz diretamente quem ela ama; em russo, é usada a palavra "mílyi", que se pode referir tanto para o marido quanto para o pai. No decorrer dos eventos da novela, o drama de Katerina é essa escolha: "É fácil perceber que a rivalidade dá um modelo de um triângulo amoroso que inclui o pai, o que é lido como uma aspiração à substituição incestuosa do namorado e a usurpação dos seus direitos ${ }^{410}$ ". Não importa o que Katerina escolha, ela será uma traidora: do seu clã ou do seu marido.

A paixão do feiticeiro pela sua filha parece óbvia: ele menciona isso várias vezes no texto. Mas há alguns momentos ambíguos em que é possivel suspeitar na heroína o sentimento recíproco escondido. Por exemplo, para o leitor parece estranho o modo como ela apela ao seu marido Danilo, dizendo: Oh! agora te conheço! És uma fera e não um homem! Tens o coração de lobo e a mente de uma víbora perversa. Pensava que tinhas ao menos uma gota de piedade, e que o sentimento humano pudesse arder no teu corpo de pedra ${ }^{411}$.

\footnotetext{
${ }^{407}$ GÓGOL, 1990, p. 59.

${ }^{408}$ COX, G. Geographical, sociological and sexual tensions in Gogol's Dikan 'ka stories.In Slavic and East European journal.Bd. 24. 3. Fall 1980. p. 219 (trad. de N.L. Vinográdskaia).

${ }^{409}$ GÓGOL, op. cit., p. 52.

${ }^{410}$ GONTCHAROV, 1993, p. 12

${ }^{411}$ GÓGOL, op. cit., pp. 52-53.
} 
Curiosamente, ela fala isso a um personagem positivo, que, supostamente, deve salvar a heroína do vilão, segundo a lógica do gótico. Até no momento em que ela renuncia o seu pai-

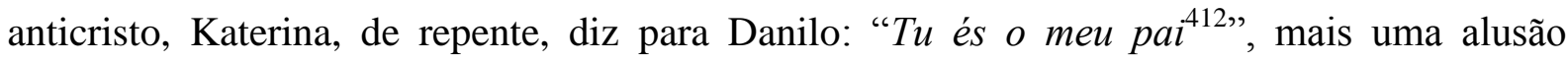
curiosa ao tema do incesto.

Apesar da escolha de Katerina a favor de Danilo, ela também trai o seu marido. O feiticeiro a convence a abrir a porta da prisão onde Danilo o colocou. A traição aqui é dupla: Katerina trai o marido, enquanto o feiticeiro a trai, porque não cumpre o juramento de se arrepender e rezar pela salvação da sua alma. Então é possível dizer que todos os heróis da novela podem ser vistos, de um modo ou de outro, como os traidores.

Katerina é uma personagem forte e trágica: ela está lutando com as forças do mal, mas não consegue vencer o feiticeiro, sozinha. Extremamente bonita, às vezes, fraca fisicamente, mas forte espiritualmente, o que é visto nas tentativas fracassadas do feiticeiro de seduzi-la, ela é um símbolo da pureza. O enlouquecimento de Katerina é um dos episódios mais fortes de $A$ Terrível Vingança: sem o marido, sem o filho, ela não sabe existir, ela é inconsolável, e, por isso, se afoga nas águas do rio Dnepr. Essa cena mostra, com toda a força, o contraste entre Katerina e o feiticeiro: o egoísmo frio contra o amor ardente pela família.

Como é possível ver, o conflito entre as personagens principais, em A Terrível Vingança, vai além das fronteiras da poética do romance gótico, embora possua muitos traços similares a esse gênero. O vilão está em conflito com a sociedade, ele é um exilado, parcialmente, uma vítima. O herói não é unívoco, tem o seu próprio conflito com a sociedade, visto na sua escolha do amor a favor do coletivo. A heroína é bela e angelical, mas, ao mesmo tempo, ela é uma traidora. Como disse Mann, "A Terrível Vingança, como vimos, realmente abre uma perspetiva extraordinariamente profunda no mundo artístico gogoliano, o fundo do qual, usando as palavras do escritor, ninguém viu ${ }^{413}$ ".

O sistema dos personagens, em $A$ noite da véspera do dia de Ivan Kupala, ao que parece, é mais simples do que na novela anteriormente analisada. Há dois heróis principais no enredo: um jovem, Petró Sem-Família, e o vilão-tentador Bassavriuk. A heroína não cumpre um papel proeminente na história, mas a sua imagem ajuda reforçar o efeito de contraste na novela.

A presença de dois personagens importantes nos lembra das exigências do teatro popular, que era, como mencionamos no prefácio, uma grande fonte de inspiração para Gógol. Como o teatro medieval de vertep era operado, de maneira geral, somente por uma pessoa, a

\footnotetext{
${ }^{412}$ GÓGOL, 1990, p. 61.

${ }^{413}$ MANN, 1988, p. 58.
} 
história poderia conter apenas dois heróis ao mesmo tempo. Na novela em questão, observa-se uma história trágica de uma queda moral da pessoa, predestinada pelos eventos dramáticos que ocorrem com o protagonista. O pesquisador Christopher Putney salienta: "Como um fantoche, uma pessoa, nos registros literários medievais, é retratada como se não tivesse controle sobre o seu destino, com suas "cordas" puxadas pelos poderes superiores diabólicos ou divinos ${ }^{414 \%}$. Exatamente isso acontece com Petró: o conflito entre as personagens principais surge e desenvolve-se diante de nossos olhos, ele possui uma explicação social. Petró é um rapaz pobre, enquanto o pai severo, Korj, quer um noivo mais rico para a sua filha. O vilão Bassavriuk vira, nessa situação, um estimulador da queda, um sedutor da alma de Petró.

Bassavriuk é a primeira personagem a aparecer na narrativa principal - o fato de que mais uma vez prova o papel dominante do vilão no texto gótico. $\mathrm{O}$ nome do vilão é significativo: na primeira versão da novela, publicada em 1830, ele era chamado de Bissavriuk, provindo da palavra ucraniana "bis", o que significa "o diabo", sublinhando o seu princípio infernal. Posteriormente, Gógol mudou o nome para "Bassavriuk", para fazer o nome do seu herói menos óbvio em seu significado simbólico.

Bassavriuk recebe, no texto, uma característica completa das suas ações e da sua aparência. Porém, como um verdadeiro vilão gótico, ele continua sendo um mistério para o leitor. Não se sabe nada do seu passado e da sua origem: De onde ele vinha, para quê, ninguém sabia ${ }^{415}$. Bassavriuk é um forasteiro - uma qualidade do vilão já mencionada por nós na análise de $A$ Terrivel Vingança. Ele não é um morador da aldeia, vem e vai embora quando quiser: Nessa mesma granja, aparecia, com frequência, um homem, ou, melhor dizendo, um diabo de aparência humana. [...] Patusca, farreia e, subitamente, some sem deixar vestígios, nem dar notícias. Mas, de repente, olha só, de novo apareceu, como caído do céu ${ }^{416}$. O seu aparecimento e sumiço estão conectados aos eventos trágicos; por isso, os moradores da aldeia, imediatamente, reconhecem nele um portador da força impura: Por que, de repente, no mesmo dia em que ele [ - Petró] enriquecera, Bassavriuk sumiu sem deixar vestígios? ${ }^{417}$. Ele surge, na aldeia, novamente depois de uma morte inesperada e horrível do protagonista: No

\footnotetext{
${ }^{414}$ PUTNEY, Christopher. Russian Devils and Diabolic Conditionality in Nikolai Gogol's Evenings on a Farm near Dikanka.New York: Peter Lang, 1999. p. 125.

${ }^{415}$ GÓGOL, 1976, tomo I, p. 41.

${ }^{416}$ Idem, Ibidem.

${ }^{417}$ Idem, Ibidem, p. 49.
} 
mesmo dia que o tinhoso carregou Petró, de novo surgiu Bassavriuk; mas todos correram dele. Perceberam agora que bicho é aquele: ninguém mais senão o Satanás ${ }^{418}$.

Assim como o feiticeiro de A Terrivel Vingança, Bassavriuk é solitário, não tem amigos verdadeiros, embora faça tentativas fracassadas de se cercar com as pessoas, entrar na comunidade da aldeia: Vai reunir os cossacos transeuntes: a gargalhada e a cantoria não cessam, o dinheiro chove; a vodca flui que nem água... Assediará, às vezes, as moças bonitas $^{419}$. Nesse sentido, ele é parcialmente parecido com Melmoth do romance de Maturin: "sombrios, isolados e independentes, eles são errantes, exilados e rebeldes condenados a vaguear as fronteiras dos mundos sociais, são portadores da verdade escura ou do

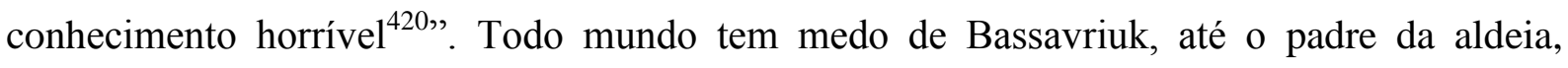
Afanássi. A anátema do padre reforça o alheamento da personagem, sua solidão extrema: Padre Afanássi anunciou, apenas, que qualquer um que se tornar amigo de Bassavriuk será considerado um católico, um inimigo da igreja de Cristo e de todos os seres humanos ${ }^{421}$. Bélyi trata essa peculiaridade da poética gogoliana como um medo irracional de um estrangeiro: “[...] 'o diabo' de Gógol é uma combinação estilística das observações de porco e do medo de um 'moscal', 'alemão', 'judeu' e 'cigano,422", Mas Bassavriuk não cabe nessas limitações. Ele possui algunas peculiaridades características de um cossaco - acima de tudo, ele gosta de farrear e beber vodca, o que indica a sua habilidade ao mimetismo, adaptação às leis do mundo real.

A aparência do vilão é descrita por meio dos detalhes tradicionais, típicos para esse tipo de personagem tanto no folclore como no gótico. Há nele traços de uma pessoa estranha, uma personificação da força maligna irreal ${ }^{423}$. De acordo com as crenças populares, o traço principal na aparência do demônio é um desvio de uma norma, uma falta ou um excesso das qualidades físicas: força, altura, feiura ou beleza marcantes.

Bassavriuk, como a maioria dos vilões em Noites, possui uma existência dupla. No mundo real, ele é um cossaco que veio de outra aldeia. Já nessa hipóstase, é possível perceber os traços ferinos e a feiura física: Qualquer um ficará com medo quando, às vezes, ele enrugar suas sobrancelhas hirsutas e lançar de soslaio um olhar que fazia qualquer um dar

\footnotetext{
${ }^{418}$ GÓGOL, 1976, tomo I, p. 52.

${ }^{419}$ Idem, Ibidem, p. 41.

${ }^{420}$ BOTTING, 1996, p. 98.

${ }^{421}$ GÓGOL, op. cit., p. 42.

${ }^{422}$ BÉLYI, 1934, p. 127.

${ }^{423}$ MANN, 1978, p. 76.
} 
no pé, Deus sabe para onde ${ }^{424}$. O seu rosto é descrito como uma carranca, o cabelo - como as cerdas, os olhos - que nem os de um touro ${ }^{425}$. Outro traço é a voz alta, caracterizada por meio dos verbos trovejou, urrou, troou. Assim como na imagem do feiticeiro, é marcante um olhar penetrante e forte: $O$ rosto de Bassavriuk, de súbito voltou à vida; seus olhos faiscaram $^{426}$.

Segundo Sofrónova, a aparência dos demônios é "por definição, mutável - o traço dominante da sua natureza é uma habilidade à transformação. Suas metamorfoses estão descritas detalhadamente, com uma indicação obrigatória que estão acontecendo de repente, inesperadamente, em um momento ${ }^{427}$ ". No mundo real, Bassavriuk é um cossaco estranho. No mundo mágico, ele é um morto-vivo, uma espécie do feiticeiro: No cepo, apareceu Bassavriuk sentado, todo azul como um morto. Não mexia nem um dedo. Seus olhos estão cravados em algo visivel só para ele; sua boca semiaberta, e nenhuma palavra sai dela ${ }^{428}$. É um dos traços mais assustadores da realidade artística gogoliana: uma habilidade de um morto de "se disfarçar" de um vivo, quer dizer, apropriar-se de algumas feições vivas, permanecendo morto. Por isso, é impossível imaginar a obra gogoliana sem a oposição-chave vivo/morto.

Como um verdadeiro diabo, Bassavriuk é extremamente rico; não por acaso, ele consegue pagar a vodca para a aldeia inteira. Nesse sentido, ele é associado ao tema do ouro amaldiçoado, divulgado no romance gótico e característico também da obra gogoliana ${ }^{429}$. $\mathrm{O}$ ouro, na novela, possui um poder hipnótico. Basta para o vilão só tilintar o seu porta-moedas e dizer a Petró que vai exigir apenas um favor pela riqueza, que o herói já está pronto para vender a sua alma.

O povo sente o caráter diabólico do personagem e da sua riqueza, tenta evitar os seus presentes: as moças bonitas hesitavam um pouco em aceitar os presentes: Deus sabe, talvez de verdade, tivessem passado por mãos impuras. A própria tia do meu avô [...] dizia justamente que não aceitaria presentes dele nem por todas as riquezas do mundo ${ }^{430}$. Seus presentes são amaldiçoados: eles atraem desgraças diferentes nas pessoas que os aceitaram: já na noite seguinte, lhe faz uma visita algum "amigo" do pântano, arrastando-se, com cornos

\footnotetext{
${ }^{424}$ GÓGOL, 1976, tomo I, p. 42.

${ }^{425}$ Idem, Ibidem, p. 45.

${ }^{426}$ Idem, Ibidem, p. 46.

${ }^{427}$ SOFRÓNOVA, 2010, p. 10.

${ }^{428}$ GÓGOL, op. cit., p. 46.

${ }^{429}$ GIÚNTER, Hans. Méjdu mamónoi i místikoi. Problemátika hudójnika v 'Portrete’ Gógolia.In MANN (Org.), 2003, p. 178.

${ }^{430}$ GÓGOL, op. cit., p. 42.
} 
na cabeça e apertando seu pescoço, se nele houver um colar ${ }^{431}$. A força mágica do vilão, porém, é limitada: ele vira um demônio somente à noite. Não por acaso, o lugar favorito onde ele gosta de passar o seu tempo é uma taberna, um lugar enfeitiçado, na tradição popular ucrainana, e relacionado a um tempo noturno (as pessoas bebem depois de trabalhar durante o dia). Os taberneiros eram ligados aos diabos, o que já é visível na outra novela gogoliana, $A$ Feira de Sorótchintsy, em que o diabo bebeu todo o dinheiro que tinha e, depois disso, começou a vaguear pelo mundo. A taberna é um lugar onde Bassavriuk seduz Petró, chegando a um acordo com ele. É também o último lugar na novela em que o leitor encontra o antagonista, aparecendo como uma cabeça de carneiro (já falamos da predominância dos traços ferinos nas personagens demoníacas):

Ai, pareceu-lhes, e não a um só, mas a todos, que o carneiro levantasse a cabeça, seu olhar vago se animasse e se iluminasse, e um bigode preto $e$ hirsuto aparecesse repentinamente a todos os presentes e, num instante, começasse a se mexer com ar de importância. Todos, imediatamente, reconheceram na cabeça do carneiro a carranca de Bassavriuk; a tia do meu avô até esperava que já-já pediria vodca... ${ }^{432}$

Essa pequena história, inesperadamente, amplia a imagem de Bassavriuk, adicionando a ele os traços cômicos. É possível dizer que as duas visões conflitantes de um diabo, a ortodoxa e a popular, terrível e ridícula ${ }^{433}$, reuniram-se nessa imagem. Chegamos a uma conclusão de que Bassavriuk é um vilão típico gótico: forasteiro, solitário, com uma aparência estranha e mutável. Na novela, ele cumpre um papel de um tentador da alma do herói, e consegue atingir o seu objetivo principal, continuando a caçar as almas, usando armas como desespero e desejo humanos; mas também possui uma dimensão cômica, o que é visível nas últimas cenas da novela.

O herói da novela é Petró Sem-Família - talvez porque ninguém se lembrasse nem do pai, nem da mãe dele. É verdade que o curador da igreja costumava dizer que eles haviam morrido de peste no mesmo ano ${ }^{434}$. O nome desse personagem possui um significado simbólico forte. Putney explica que, em Gógol, nomes "não traçam uma equivalência explícita entre o seu portador e alguma qualidade absoluta importante, mas normalmente

\footnotetext{
${ }^{431}$ GÓGOL, 1976, tomo I, p. 42.

${ }^{432}$ Idem, Ibidem, p. 52.

${ }^{433}$ PUTNEY, 1999, p. 127.

${ }^{434}$ GÓGOL, op. cit., p. 42.
} 
servem como sinais de que algo está errado ${ }^{435}$ ". Petró é um dos nomes frequentes em Gógol que, quase sempre, indica um traidor - talvez relacionado ao contexto bíblico de Pedro que traiu Jesus três vezes. Já observamos o traidor Petró, de $A$ Terrivel Vingança: assim como em A noite da véspera, ele mata Ivan. Nas obras mais tardias, observam-se derivações do nome Petró, como uma figura demoníaca, Petróvitch, em $O$ Capote, e o usurário-tentador, de O Retrato, Petromikháli.

O apelido Sem-Família é também significativo. É uma definição que indica uma ausência da família na vida do protagonista, o que, no mundo das leis do clã, é considerado uma deficiência grande. "Tudo que é deficiente é mal”, discutia Tomás de Aquino, em Summa Theologica. Ele usou o exemplo de surdez como mal, indicando que, como as pessoas deveriam ser capazes de ouvir, aquelas que não podem são impedidas de realizar por completo a sua personalidade ${ }^{436}$ ". O herói de Gógol é um órfão. Gontcharov observa que todas as famílias, em Noites, são marcadas pela deficiência e incompletude; é uma situação inicial do enredo. A família típica nas novelas é pai + filha/filho + madrasta ou cunhada ${ }^{437}$. Por isso, ele tenta obter, através do casamento, uma família verdadeira. Um orfão, em Gógol, é mais acessível à influência das forças impuras. Por isso, a tia do falecido avô fazia de tudo para lhe dar parentes ${ }^{438}$. Mas os seus esforços fracassam, pois o pai de Petró é também um forasteiro que ninguém nunca viu: o seu pai estava em Zaporójie, antes disso - caíra prisioneiro dos turcos, sofrera Deus sabe que tormentos e, por algum milagre, tendo se disfarçado de eunuco, dera no pé $e^{439}$.

Em contraste com o vilão, Petró é um rapaz bonito. Tem bigode negro [...], o seu oselédets [...] já está enrolado duas vezes em torno da sua orelha ${ }^{440}$. O objetivo da outra caracterização da aparência do herói é mostrar a sua pobreza - o traço que entra no contraste com a riqueza do vilão:

Diziam somente que ele colocaria todos os rapazes daquele tempo no chinelo se the vestissem um jupan novo, o apertassem com um cinto vermelho, lhe pusessem na cabeça um chapéu feito de smuchkas pretas com uma elegante copa azul, pendurassem uma espada turca na anca e colocassem uma chibata numa mão e na outra um cachimbo de aro bonito.

\footnotetext{
${ }^{435}$ PUTNEY, 1999, p. 146.

${ }^{436}$ GÓGOL, 1976, tomo I, p. 147.

${ }^{437}$ GONTCHAROV, 1993, p. 10.

${ }^{438}$ GÓGOL, op. cit., p. 42.

${ }^{439}$ Idem, Ibidem.

${ }^{440}$ Idem, Ibidem, p. 44.
} 
Mas, infelizmente, o pobre Petró tinha apenas um camisolão cinza com mais buracos do que moedas de ouro nos bolsos de algum judeu ${ }^{441}$.

Ao longo das histórias de Noites, os personagens parecem dependentes por completo das forças externas. A psicologia individual é praticamente ausente, pois os humanos se comportam de uma maneira involuntária, e Petró é um dos exemplos disso. Às vezes, o envolvimento do diabo no seu destino é explícito, mas, em alguns casos, o leitor precisa deduzir se é a força impura de verdade que está 'puxando as cordas' do protagonista ${ }^{442}$. O fenômeno do qual estamos falando é denominado, pelo renomado estudioso Meletínski, como “deseroicização", característico do universo artístico de Gógol, com sua "crescente tendência à representação de um herói sem personalidade, vítima do alheamento, em parte devido à sua aproximação semi-heróica aos muitos arquétipos mitológicos e culturais que se transformaram em máscaras descartáveis ${ }^{443}$ ".

Petró é um típico herói sem personalidade. A sua tragédia é predeterminada, em primeiro lugar, pela sua condição deficiente - social e familiar, e, em segundo lugar, pelas circunstâncias e coincidências dramáticas. As forças malignas interferem de um modo constante e aberto na sua vida. É visível na cena quando o pai da heroína vira uma testemunha involuntária de um beijo dos namorados. O narrador salienta a influência do diabo no acontecimento:

[...] não teria vindo à mente de Korj nenhuma má intenção se uma vez (aí, é claro como água que não fora outro senão o tinhoso que tentou) não viesse à cabeça de Petró, sem pensar bem, na entrada da casa, lascar um beijo como eles dizem - de todo o seu coração, nos lábios rosados da cossaca. Aquele mesmo tinhoso (que ele, o filho de uma égua sonhe com a santa cruz!) levou o velho caduco a abrir a porta da casa, de bobeira ${ }^{444}$.

Quem salva o herói, nessa situação, é uma criança - o irmão da heroína, Ivás. Como vimos, o nome Ivan, em Noites, também é marcado por um destino infeliz: os Ivans perecem, quase sempre por causa de algum Petró. Um aparecimento de uma criança nessa novela é marcante, porque ela simboliza inocência. Curiosamente, Ivás pode ser visto como um

\footnotetext{
${ }^{441}$ GÓGOL, 1976, tomo I, pp. 42-43.

${ }^{442}$ PUTNEY, 1999, p. 132.

${ }^{443}$ CAVALIERE, 2009, pp. 125-126.

${ }^{444}$ GÓGOL, op. cit., p. 43.
} 
pequeno anjo da guarda do protagonista: ele defende Petró de Korj, no mundo real, e, no mundo mágico, ele, provavelmente, poderia defender Petró da força impura, se o último não obedecesse Bassavriuk.

Apesar do fato de que o destino trágico de Petró seja predeterminado, ele possui uma escolha. Na cena do lamento dos namorados, Gógol mostra para nós as duas alternativas do caminho do herói: resignação e uma luta difícil pela felicidade. A heroína é inconsolável, mas não acusa Deus: amaria seus olhos castanhos, beijaria seu rosto branco, mas o meu destino não me permite ${ }^{445}$. Diferentemente dela, Petró não quer desistir, está procurando um caminho da situação difícil. Antes de chegar a um acordo com Bassavriuk, ele pensava em ir à Crimeia e à Turquia ganhar ouro na guerra e, com os bens, voltar ${ }^{446}$. Mas ele escolhe um caminho mais fácil - vender a sua alma, e vai à taberna. É importante salientar que Petró, de forma voluntária, entra em contato com a força impura. Mais do que isso, ele quer esse contato e o procura. A intenção de Petró faz-se óbvia, porque ele entra no lugar na hora em que uma boa alma vai às matinas ${ }^{447}$ - na igreja ortodoxa, as matinas são ministradas logo depois das vésperas, isto é, à noite. Então, em vez de ir à igreja para rezar, o herói resolve afogar suas mágoas $^{448}$. Ele é ciente de que está lidando com Satanás, não pode existir um erro nisso: “Diabo!" - gritou Petró. - "Vamos! Estou pronto a fazer qualquer coisa! ${ }^{449, "}$

A cena horrível, no Medvéji Ovrag, é um episódio de uma luta verdadeira pela alma do protagonista. Por um lado, um vilão e a sua aliada, a bruxa - poderosos à noite, mas incapazes de fazer algo sem a vontade do herói. Por outro lado, Petró e o irmão de Pidorka, que podem vencer se juntarem as suas forças. No início, a vitória do bem é possível, porque Petró primeiro hesita em derramar sangue:

Não é uma piada cortar sem razão a cabeça de algum homem, e ainda de uma criança inocente! Encolerizado, ele tirou o lençol que cobria a cabeça do menino, e o que ele vê, então? Na frente dele, estava Ivás. A coitada da criança pôs as mãozinhas cruzadas e abaixou a cabeça... Furioso, ele deu um salto com a faca em direção à bruxa e até já levantara o braço para golpeá-la... ${ }^{450}$

\footnotetext{
${ }^{445}$ GÓGOL, 1976, tomo I, p. 44.

${ }^{446}$ Idem, Ibidem.

${ }^{447}$ Idem, Ibidem, p. 45.

${ }^{448}$ Idem, Ibidem.

${ }^{449}$ Idem, Ibidem.

${ }^{450}$ Idem, Ibidem, p. 47.
} 
Mas um manipulador e um tentador, Bassavriuk usa o grande ponto fraco do protagonista - a sua paixão: E o que você prometeu pela moça? - troou Bassavriuk, como se atirasse uma bala nas costas de Petró ${ }^{451}$. É importante anotar que $A$ noite da véspera é a única novela da primeira parte da coletânea em que o derramamento de sangue ocorre, e que também tem um final tão infeliz. O momento do assassinato da criança, na novela, é uma descrição quase surreal. O herói entra em uma condição de espírito fronteiriço, muito próximo de uma alucinação ou até loucura: Os seus olhos incendiaram-se... a mente se perturbou... Como um louco, ele agarrou a faca, e o sangue inocente esguichou em seus olhos... [...] Tudo girava em sua cabeça! ${ }^{452}$. A escolha trágica do herói acontece nesse exato momento - uma escolha errada, que o conduz a uma perda de memória. Depois da noite terrível, Petró não lembra o rosto de Ivás - um índice de um feitiço forte e irreparável.

O sucesso aparente do herói - a riqueza e o casamento - torna-se uma desgraça para o casal: a loucura de Petró e, depois, a sua morte. Como sempre, o povo sabe intuitivamente as razões para isso: "Do diabo não virá nada de bom!" - diziam elas em coro ${ }^{453}$. A doença de Petró traz para a novela o tema da perda de memória. O único jeito de se curar, para o protagonista, é, provavelmente, a vitória sobre o demônio no mundo real: “O reconhecimento das personagens demoníacas é uma tarefa importante que uma pessoa resolve no encontro com elas ${ }^{454 \%}$. Mas é impossível: Bassavriuk sumiu, e Petró é condenado a uma morte no delírio.

O processo da autodestruição do herói é mostrado por Gógol com perfeição. O protagonista é amaldiçoado, ele carrega uma marca de um poder maligno irreal, que é descrita como uma ausência de movimento e silêncio: Fica sentado no mesmo lugar e não troca palavras com ninguém $^{455}$. Parece que o tempo parou para Petró: ele está preso no mesmo momento em que cometera o pecado mortal. É destacado o princípio ferino - de repente, o herói está se aproximando do vilão em sua aparência: Asselvajou-se, ficou peludo, feio [...] A fúria o domina; como um demente, roi e morde suas mãos e, por despeito, arranca as madeixas do cabelo ${ }^{456}$.

A morte horrível do protagonista é um final lógico do seu caminho da vida: é uma das cenas acentuadas que contém em si um sentimento de catarse. Um jovem pobre, órfão, Petró

\footnotetext{
${ }^{451}$ GÓGOL, 1976, tomo I, p. 47.

452 Idem, Ibidem, p. 49.

${ }^{453}$ Idem, Ibidem.

${ }^{454}$ SOFRÓNOVA, 2010, p. 11.

${ }^{455}$ GÓGOL, op. cit., p. 49.

${ }^{456}$ Idem, Ibidem, pp. 50-51.
} 
está destinado ao sofrimento: uma vida infeliz à parte da sua namorada. Ele é escolhido pelas forças superiores para cumprir uma tarefa que exige dele uma força interior máxima, uma escolha moral difícil. O herói não está preparado para isso e decide assinar um pacto com o diabo, não entendendo as consequências do seu feito. $\mathrm{O}$ seu castigo começa imediatamente depois do crime cometido: a sua vida torna-se o inferno. Todas as suas forças são gastas em vão para se lembrar do único momento decisivo: os eventos horríveis da noite da véspera de Ivan Kupala. O dinheiro obtido no caminho errado, depois da sua morte, torna-se os cacos quebrados. O próprio Petró queima no fogo infernal.

Como a heroína clássica gótica, Pidorka, de $A$ noite da véspera do dia de Ivan Kupala, é esteriotipadamente feminina e bonita. A descrição da sua beleza é construída pelo escritor por meio dos epítetos tirados das canções populares, como tão bela que eu duvido que vocês já tenham tido chance de ver algo parecido; as bochechas rosadas e ardentes como uma papoula; sobrancelhas como as cordas negras ${ }^{457}$, voz de rouxinol etc. A imagem que o escritor cria é rica em cores e nos lembra uma pintura colorida. O crítico do início do século XX, N. Kotliarévski, comentou sobre as beldades rurais gogolianas: "não são frágeis, pálidas e aéreas como as mulheres do romantismo daquela época; elas não desaparecem na névoa. Pelo contrário, são muito saudáveis, coradas [...] mesmo assim, são aparentadas àquelas irmãs pálidas, também tendo pouco em comum com a vida real ${ }^{458 \%}$. Parcialmente, discordamos com a avaliação do crítico, mas é possível dizer que a beleza, em Gógol, é sempre hiperbolizada, o que também foi notado pelo simbolista Valéri Briússov ${ }^{459}$.

Em muitos casos, Pidorka é passiva diante das circunstâncias difíceis da sua vida. A sua primeira reação a um casamento forçado com um polaco é choro e resignação: Inundei em lágrimas amargas não apenas uma toalha. Não aguento. Tenho um peso no coração ${ }^{460}$. A fala da heroína é uma referência a um gênero folclórico de lamento (platch) nupcial, divulgado na cultura russa. Para o lamento, são característicos elementos como uma queixa sobre o seu destino e um pressentimento da morte próxima. Ambos são visíveis no lamento de Pidorka:

E meu próprio pai é o meu inimigo: está forçando-me a casar-me com um polaco que não amo. [...] Não vou dançar com meu noivo; me carregarão.

\footnotetext{
${ }^{457}$ GÓGOL, 1976, tomo I, p. 43.

${ }^{458}$ KOTLIARÉVSKI, N. Nikolai Vassílievitch Gógol': Ótcherki iz istórii rússkoi póvesti i dramy. SanktPeterburg, 1903, p. 106 Apud Dmítrieva, 2011, p. 20.

${ }^{459}$ BRIÚSSOV, Valéri. Isspepeliónnyi.K kharakterístike Gógolia.In GONTCHAROV (Org.), 2009, p. 456.

${ }^{460}$ GÓGOL, op. cit., tomo I, p. 44.
} 
Escura, escura será a minha casa - feita de madeira de pinos, e no lugar da chaminé, a cruz vai ficar fincada no telhado! ",461

Na opinião de Putney, a heroína está ameaçando o herói com o suicídio. Essa hipótese parece imprecisa: o suicídio é um pecado terrível, na consciência arcaica ortodoxa, e a heroína parece dócil demais para tal feito. Ela simplesmente repete as formas poéticas da expressão da mágoa.

Porém o amor verdadeiro transforma Pidorka. A desgraça na família a faz decisiva, pronta para lutar contra a doença de Petró. A mulher recorre aos remédios populares: $O$ que não fazia Pidorka: consultava os curandeiros, tentara adivinhar o que havia causado sobressalto e fizera um chá de sono - nada ajudava ${ }^{462}$. A preocupação com o marido priva Pidorka daquilo que a definia antes - a sua beleza: já não se podia reconhecer a Pidorka de antes. Nenhuma cor nas bochechas, nenhum risinho: desolada, debilitada, debulhara os olhos claros em lágrimas ${ }^{463}$. Sem saber do crime cometido por Petró, da sua traição (porque a criança assassinada era seu irmão), a heroína torna-se uma vítima involuntária da maldição familiar, também sofrendo do tormento emocional: A vida se tornou insuportável para Pidorka $^{464}$. Desesperada, a heroína decide consultar uma curandeira, o que, na tradição popular, era considerado um pecado. Nesse momento, o autor mostra como Pidorka é corajosa: sozinha, ela vai à noite, na floresta escura, para procurar o remédio para Petró. No momento em que Petró está atacando a bruxa na sua casa, ela vê o fantasma do seu irmão e até tenta salvá-lo: "Ivás!" - gritou Pidorka e se lançou em sua direção, mas o fantasma ficou ensanguentado [...]. Apavorada, ela correu para a entrada da casa. Ao recobrar os sentidos, queria ajudá-lo; em vão! 465 $^{40}$

Uma vítima involuntária do pecado do marido, Pidorka tenta rezar pela sua alma no monastério. O destino da heroína é típico para o romance gótico: ela se retira para um convento para se tornar uma monja ascética, aparentemente para expiar a sua culpa e o envolvimento com as forças malignas ${ }^{466}$.

Como é possível ver, em $A$ noite da véspera do dia de Ivan Kupala, existe uma oposição inequívoca entre o herói e o vilão. $\mathrm{O}$ vilão possui várias feições típicas para o gótico.

\footnotetext{
${ }^{461}$ GÓGOL, 1976, tomo I, p. 44.

${ }^{462}$ Idem, Ibidem, p. 49.

${ }^{463}$ Idem, Ibidem, p. 51.

${ }^{464}$ Idem, Ibidem.

${ }^{465}$ Idem, Ibidem.

${ }^{466}$ PUTNEY, 1999, p. 129.
} 
Um representante do mundo alheio, ele é caracterizado, também, através do seu comportamento. É importante o tema da bebedeira - o efeito de embriaguez, no mundo gogoliano, é, às vezes, visto como um estado fronteiriço entre os espaços real e mágico. $\mathrm{O}$ herói e a heroína, ao que parece, não possuem vontade própria, são dirigidos pelo seu destino, caem vítimas dos obstáculos sociais e facilmente se entregam nas mãos do vilão - um enredo típico para o romance gótico "negro".

Uma noite de maio, ou uma moça afogada é uma história com um final feliz. Das novelas aqui analisadas, é a mais próxima do princípio carnavalesco, com suas travessuras alegres dos namorados, zombaria e confusão festivas do "mundo às avessas" e o caráter ambivalente de todos os acontecimentos. Por isso, observam-se, no enredo, as duas linhas principais: a trágica e a cômica. Em alguns casos, elas são paralelas; em outros, elas complementam uma a outra. As duas histórias são ligadas por meio da figura do protagonista, que é capaz de atravessar a fronteira entre os espaços, real e mágico. As histórias da pánnotchka e de Levkó são fortemente entrelaçadas, uma não pode existir sem outra. Os dois enredos possuem várias feições em comum: em ambos, é possível observar o tema latente do incesto, as heroínas em ambos os mundos são passivas diante do mal e esperam o seu salvador. Por causa das peculiaridades aqui mencionadas, há, na novela, dois antagonistas (a bruxa e o cabeça) e dois protagonistas (a pánnotchka e Levkó). A heroína do mundo real, Ganna, é associada à pánnotchka; sua imagem merece um estudo adicional.

A bruxa é uma das personagens mais frequentes e específicas nas novelas da coletânea. Geralmente, quase todas as mulheres, em Noites, potencialmente, podem ser vistas como uma bruxa ${ }^{467}$. A imagem em questão, no mundo artístico gogoliano, é parcialmente inspirada nos contos populares eslavos "bylitchki". Tais relatos foram divulgados na Rússia, no início do século XIX, ou seja, no momento em que Gógol escreveu as suas novelas ucranianas.

A vilã-bruxa, de Uma noite de maio, aparece representada, na novela, por três imagens: como uma madrasta maldosa, como uma gata e como uma sereia (que na novela é chamada de uma moça afogada). Como uma madrasta, a bruxa aparece, pela primeira vez, na narrativa de Levkó: Era toda rosa e branca a jovem esposa; só que foi tão terrível o olhar que lançou para a enteada, que esta soltou um grito ao vê-la; e nem uma palavra lhe disse a severa madrasta durante o dia inteiro ${ }^{468}$. Vários detalhes chamam a atenção nessa descrição. Em primeiro lugar, é uma mulher de uma beleza excepcional, típica das vilãs góticas. Os

\footnotetext{
${ }^{467}$ VIROLÁINEN, Maria. Ránni Gógol': Katastrofizm soznániia.In MANN (Org.), 2003, p. 11.

${ }^{468}$ GÓGOL, 1976, tomo I, p. 57.
} 
epítetos que Gógol usa para ela - "rosa e branca” (em russo: rumiána e belá) são descomunais para as bruxas do folclore russo: "rosa e branca" é usado para descrever as belas heroínas. As bruxas nas bylitchki foram sempre descritas como feias e velhas. Acreditamos que, nessa descrição da beleza superficial, sem o conteúdo interno, aparece pela primeira vez um tema muito importante para o autor: o medo de uma mulher bonita, de uma beleza que pode, de algum modo, ser relacionada à esfera dos instintos carnais. Gógol aprofunda-se nesse tema no decorrer da sua obra. Essa beleza pode ferir e até destruir o personagem. Exatamente isso acontece com o pai da pánnotchka. Enfeitiçado pela bruxa, ele condena a sua filha e a manda embora da própria casa, cometendo o pecado mortal da traição da família. Não por acaso, a heroína diz: Você deixou sua própria filha perecer, meu pai! A bruxa arruinou a sua alma pecadora! ${ }^{469}$ Outra característica importante, na descrição da madrasta, é o seu olhar penetrante que assusta a heroína, já analisado por nós, anteriormente, nos outros antagonistas da coletânea.

A segunda natureza da bruxa - a de gata - tem suas raízes no folclore: "Segundo as crenças populares, o diabo e a bruxa [...] assumem uma imagem de um animal doméstico ou selvagem, um pássaro etc. Assustando as pessoas, à noite, os feiticeiros e as bruxas correm em forma de porcos, cachorros e gatos ${ }^{470}$ ". Na novela, a heroína é atacada pela gata preta com suas garras de ferro - um episódio assustador, provavelmente digno de um romance de terror:

De repente, vê uma horrivel gata preta se aproximando dela de mansinho; sua pele arde e as garras de ferro arranham o chão. Espantada, ela saltou num banco - a gata seguiu atrás dela. Atravessou num pulo para o leito - a gata também, e subitamente se atirou em seu pescoço, estrangulando-a. Arrancou-a de si com um grito, jogou-a no chão; de novo se aproxima a horrivel gata ${ }^{471}$.

Aqui Gógol relata um episódio frequente das bylítchki, em que a pessoa corta a pata de um animal maldoso e depois descobre que cortara a mão de uma bruxa: uma pata com garras de ferro caiu e a gata, com um ganido, desapareceu num canto escuro. O dia inteiro a jovem esposa não saiu do seu quarto; no terceiro dia, saiu com uma mão enfaixada ${ }^{472}$.

\footnotetext{
${ }^{469}$ GÓGOL, 1976, tomo I, p. 58.

${ }^{470}$ MANN, 1978, p. 115.

${ }^{471}$ GÓGOL, op. cit., p. 58.

${ }^{472}$ Idem, Ibidem, p. 58.
} 
É também coerente relacionar essa cena com um episódio da biografia do próprio Gógol. Aos cinco anos, o pequeno Nikolai foi deixado sozinho em casa. O quarto estava silencioso, e o então jovem autor ficou muito assustado. Ele lembrava: De repente, ouvi um miado fraco de uma gata... Nunca vou esquecer como ela estava caminhando, esticando-se, e as patas macias batiam nas tábuas do chão com as garras, os olhos verdes brilhavam com uma luz desagradável. Eu senti um pavor ${ }^{473}$. Depois a criança agarrou a gata e a afogou no lago. É provável que, por causa desse episódio, Gógol descrevia os gatos em sua obra como animais horrendos. Na opinião de Karassióv, "A gata afogada, o terror do acontecimento não deixavam de ser esquecidas [...], manifestando-se em identificação da gata e da bruxa - já não em plano folclórico, mas profundamente pessoal, e no tema da água [...], ao lado da qual ocorre algo terrivel $^{474, "}$.

Finalmente, a bruxa aparece num dos capítulos como uma sereia. As bylítchki não possuem nenhum enredo parecido. De acordo com as crenças eslavas, a bruxa que afogara no lago deveria perder seus poderes mágicos. Transformando uma imagem folclórica, Gógol a aproxima da poética do gótico. No mundo alheio, a bruxa recebe vários poderes sobrenaturais. Ela tem uma habilidade de mimetismo, já mencionada por nós em relação ao feiticeiro de A Terrivel Vingança: transformou-se debaixo da água numa das moças afogadas e assim escapou de um açoite de cana verde com o qual as moças afogadas intentaram batê-la ${ }^{475}$. A bruxa também continua torturando a heroína com sua presença, não a deixa em paz, está mantendo a pánnotchka numa espécie de um cativeiro emocional: eu sinto que está aqui. Sinto um peso, uma falta de ar por causa dela ${ }^{476}$. Gontcharov, no artigo já citado, indicou na semântica adicional da palavra "afogada" (em russo: utóplennitsa) - "plénnitsa", que significa "moça cativa 477 ".

Como uma verdadeira vilã gótica, a bruxa é cruel e até feroz, inclusive no nível físico. É possível observar isso na cena do jogo de corvo, quando Levkó consegue adivinhar a bruxa entre as outras moças:

Perseguia a fileira com velocidade e audácia, e se atirava para todos os lados, tentando capturar sua vítima. Neste momento, Levkó começou a perceber que seu corpo reluzia de um jeito diferente das outras: dentro dele

\footnotetext{
${ }^{473}$ ZOLOTÚSSKI, 2005, p. 27.

${ }^{474}$ KARASSIÓV, 2012, p. 144.

${ }^{475}$ GÓGOL, 1976, tomo I, p. 58.

${ }^{476}$ Idem, Ibidem, p. 76.

${ }^{477}$ GONTCHAROV, 1993.
} 
se via algo negro. De repente, ressoou um grito: o corvo se atirou sobre uma das moças da fileira, agarrou-a, e pareceu a Levkó que suas garras se mostraram e, em seu rosto, fulgurou uma alegria maldosa ${ }^{478}$.

Nessa descrição, estão visíveis todas as feições de uma vilã gótica: uma habilidade de mudar de acordo com as circunstâncias; o caráter maligno, mostrado através das qualidades físicas (algo negro), o princípio ferino (garras) e o olhar fulgurante e assustador. Como na maioria das novelas ucranianas, a bruxa de Uma noite de maio é decifrada rapidamente, aparecendo "com todos os acessórios". Nessa personagem, as feições folclóricas e góticas estão amalgamadas em uma imagem peculiar. Segundo James Holquist, "existe uma semelhança entre os modos góticos e os do conto maravilhoso [...] O mais importante dessa semelhança seria o fato de que ambos lidam com o sobrenatural, cada um tendo os seus procedimentos e personagens característicos ${ }^{479}$ ". Pode-se dizer que Gógol transforma a imagem da bruxa segundo as leis da sua própria poética, mas, ao mesmo tempo, mantém a sua conexão, tanto com as bylitchki quanto com o romance de terror. Foi adicionado a tudo isso o medo pessoal do escritor das gatas, provindo da sua infância, o que lhe ajudou a criar uma imagem complexa e assustadora da vilã na novela.

Assim como a bruxa, a heroína da história, pánnothcka, é muito bonita. Para a sua descrição, Gógol usa o mesmo padrão de beleza já estabelecido na imagem de Katerina, de $A$ Terrivel Vingança. As feições marcantes da heroína são a sua palidez, os cílios grandes e um riso que desconcerta o herói. A heroína é mostrada por meio dos olhos de Levkó. Tal procedimento ajuda o escritor a ser mais objetivo na história: Com seus longos cílios, ela semicerrava os olhos. Toda ela era branca como papel, como o brilho da lua crescente; mas como era admirável, como era bonita! Ela se pôs a rir... Levkó estremeceu ${ }^{480}$. Em contraste com a vilã, a pánnotchka não possui uma beleza assustadora: ela é mais calma, comparada na novela ao brilho mágico da lua.

Semelhante aos outros heróis da coletânea, a pánnotchka possui uma família incompleta. É importante a ausência da mãe, que poderia proteger a heroína das forças impuras, apresentadas pela madrasta - uma mãe falsa, que é associada a uma esfera infernal $^{481}$. O estudioso Putney salienta que "a mente ortodoxa compreende o mal como

\footnotetext{
${ }^{478}$ GÓGOL, 1976, tomo I, p. 77.

${ }^{479}$ HOLQUIST, James M. The Devil in Mufti: The Märchenwelt in Gogol's Short Stories. In PMLA, Vol. 82, n.5 (Oct., 1967), p. 358.

${ }^{480}$ GÓGOL, op. cit., p. 75.

${ }^{481}$ GONTCHAROV, 1991, p. 11
} 
privação, incompletude, ausência em vez de presença, o diabo como 'uma coisa vazia', em um esforço de justificar a presença do mal radical no cosmos sem fazer o Deus cristão monoteísta responsável por isso ${ }^{482} \%$. Nesse sentido, a orfandade parcial pode ser considerada um grande perigo para a heroína.

No conflito entre a madrasta e a enteada, é possível delinear uma certa temática incestuosa. Antes do aparecimento de uma nova esposa, o pai amava muito a sua filha: "Vai me mimar como antes, meu pai, quando casar com outra mulher?"- "Vou, minha filha; com

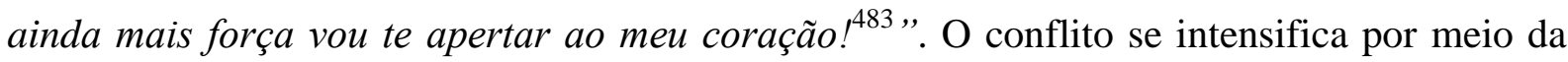
figura do pai, que, por causa do feitiço, não ama mais a sua filha. A luta é, então, pelo coração do sótnik. Parece simbólico, nesse sentido, que a pánnotchka corta a pata da bruxa gata com o sabre do seu pai, mas depois disso logo é vencida pela bruxa.

Como uma heroína gótica, a pánnotchka sofre por causa de muitas injustiças e desgraças. Ela é uma vítima passiva do destino, não sabe resistir às circunstâncias dramáticas. A madrasta tira tudo da sua enteada: a sua casa, a sua riqueza, até a sua beleza: Olhe o meu rosto: ela tirou o corado das minhas bochechas com seus feitiços impuros. [...]; e os meus olhos, olhe para eles: não enxergam mais de tantas lágrimas... ${ }^{484}$. Passo a passo, a madrasta faz a vida da pánnotchka insuportável. É um desenvolvimento do enredo típico do romance gótico - por exemplo, assim acontece em Os mistérios de Udolpho, com Emily St. Aubert, cuja vida também foi muito dolorosa por causa da sua tia severa e do seu marido. Observa-se algo semelhante no destino da pánnotchka: No quinto dia, o sótnik expulsou sua filha descalça de casa e não lhe deu nem um pedaço de pão para levar ${ }^{485}$. A morte trágica da heroína, à beira do lago, termina o seu caminho no mundo real, criando uma tarefa grande para o protagonista: reparar a injustiça que aconteceu com ela.

Se, no mundo real, a moça afogada não pode combater a má vontade da madrasta, no mundo mágico, ela recebe os poderes para lutar com ela. Parcialmente, ela consegue se vingar, afogando a mulher no lago. Mas o poder da pánnotchka é limitado: ela é cega, não consegue reconhecer a sua inimiga entre as outras sereias. Para receber a liberdade na vida póstuma, ela precisa de um herói. Curiosamente, uma das frases da pánnotchka a aproxima dos mortos, no cemitério, em A Terrivel Vingança. Assim como eles, a moça afogada está

\footnotetext{
${ }^{482}$ PUTNEY, 1999, p. 145.

${ }^{483}$ GÓGOL, 1976, tomo I, p. 57.

${ }^{484}$ Idem, Ibidem, p. 76.

${ }^{485}$ Idem, Ibidem, p. 58.
} 
sentindo um peso, uma falta de ar, porque não consegue se vingar. É possível pressupor que o tema da vingança, central para a poética do gótico, é um dos mais marcantes nessa novela.

Levkó é o protagonista da história, o único herói que aparece em ambos os enredos principais. O caráter do personagem é relativamente individualizado, comparado com os outros heróis da coletânea, por exemplo, Petró, de A noite da véspera do dia de Ivan Kupala. Ele é, antes de tudo, um músico, sabe tocar a bandurra e compôr as canções. Essa feição parece importante para o compreendimento do herói: na tradição romântica russa, a ideia da música foi vista como um elo entre o mundo de Deus e o mundo infernal, e, por isso, o músico foi considerado um mediador entre esses dois mundos ${ }^{486}$. No primeiro capítulo, o narrador faz uma observação que Levkó andava pé ante pé, esquivou-se dos cantores $^{487}$. Uma inclinação à solidão também caracteriza o herói como contemplativo, sonhador, diferente dos outros cossacos.

Ao mesmo tempo, Levkó é um herói típico: um jovem cossaco, às vezes, um pouco leviano, que gosta de fazer piadas e travessuras com seus amigos, o que é visto como um comportamento normal: Sempre me sinto entediado quando não consigo farrear com gosto e fazer bastante travessuras. É como se algo estivesse me faltando. Como se tivesse perdido um gorro ou um cachimbo; numa palavra, não me sinto cossaco e pronto ${ }^{488}$.

A aparência do protagonista é apresentada por meio dos olhos apaixonados da sua namorada, com os epítetos típicos: Eu te amo, meu cossaco de cabelos negros! Amo você porque tem olhos castanhos e, quando você me olha, parece que minha alma sorri; ela se sente tão alegre e feliz, porque alisa seu bigode negro com tanta graça ${ }^{489}$.

Com as frases simples, o narrador mostra como o herói está apaixonado pela sua namorada Ganna: Não tenha medo: não há ninguém. A noite está morna. Mas mesmo se alguém aparecer, eu te cobrirei com meu camisolão, te envolverei com meu cinto, te acolherei em meus braços - e ninguém nos verá ${ }^{490}$. Em Noites, a psicologia dos personagens não é muito desenvolvida. Como foi notado por vários pesquisadores, a prosa de Gógol não pode ser chamada psicológica, pelo menos, no sentido tradicional dessa palavra. A fala do

\footnotetext{
${ }^{486}$ Para ler mais sobre o tema da música na literarura russa, ver IASIUKÓVITCH, I. V. Muzykál'nye obrazy v rússkoi romantítcheskoi proze 30-40kh godov XIX veka. Kolómna: Kolómenski gosudárstvennyi pedagogítcheski institut, 2003.

${ }^{487}$ GÓGOL, 1976, tomo I, p. 54.

488 Idem, Ibidem, p. 64.

${ }^{489}$ Idem, Ibidem, p. 56.

${ }^{490}$ Idem, Ibidem, p. 55.
} 
herói, os gestos, as suas ações e reações, então, substituem a psicologia ${ }^{491}$. No caso de Levkó, são aplicadas as fórmulas retóricas, típicas para descrever o seu sentimento pela namorada, como: mesmo uma hora sem você é amarga para mim $^{492}$.

O enredo fantástico e o encontro do protagonista com a moça afogada são transferidos para o sonho do jovem, mas os acontecimentos têm suas consequências no mundo real. $\mathrm{O}$ sonho como um procedimento artístico é importante para a poética do gótico. Afirma BayerBerenbaum que o sonho, como uma alternativa ao ordinário mais comum, e os pensamentos dos heróis nos momentos dos seus despertares, "recebe atenção considerável nos romances góticos [...] Dentro do romance gótico, personagens questionam se eles estão acordados ou apenas estão sonhando ${ }^{493}$ ".

Como um herói verdadeiro, Levkó pede ajuda da pánnotchka em amor. Ele não precisa da riqueza, como, por exemplo, Petró, de A noite da véspera do dia de Ivan Kupala. Por isso, no sistema artístico gogoliano, ele volta do mundo alheio como um vencedor.

O conflito principal de Levkó está no mundo real, com o seu pai severo, que não the deixa casar com a sua namorada. Por isso, Levkó está entrando em uma oposição, parcialmente cômica, com o seu pai, que, na novela, é chamado de "cabeça", quer dizer, do chefe da aldeia, assim criando várias piadas baseadas no jogo das palavras. Como um vilão, o cabeça recebe uma característica muito mais detalhada do que o protagonista. Várias feições da sua aparência podem ser vistas como típicas do gótico. Em primeiro lugar, é destacada a natureza infernal do cabeça. O estudioso Mansikka escreve que "os demônios antropomórficos mostram, em todo caso, alguma feição peculiar que os distingue dos humanos". Entre os exemplos que ele cita, há "a ausência de algum órgão proeminente do corpo, como um olho ou uma orelha ${ }^{494, "}$. Como está escrito na novela, o cabeça é zarolho e, às vezes, finge de ser surdo. O bigode grande também pode ser visto como uma feição demoníaca em Gógol, assim como o olhar forte e pesado, característico desse personagem: lançar de soslaio olhares de falcão ${ }^{495}$. São também significativas as comparações ferinas. $\mathrm{O}$ cabeça é comparado com um gato (Assim, somente um gato velho e experiente deixa um rato inexperiente correr ao lado do seu rabo; e, enquanto isso, cria rapidamente um plano de

\footnotetext{
491 SEKÁTSKI, Aleksandr. Gógol' - otkrovénnoe i sokrovénnoe.In LEVENTAL' V., DRUGOVÉIKODOLJÁNSKAIA S., KRUSSÁNOV P. (Org.). Literatúrnaia mátritsa.Utchébnik, napissannyi pissáteliami.Sankt-Peterburg - Moskvá: Limbus Press, 2011. pp. 99-100.

${ }^{492}$ GÓGOL, 1976, tomo I, p. 55.

493 BAYER-BERENBAUM, 1982, p. 25.

${ }^{494}$ PUTNEY, 1999, p. 148.

${ }^{495}$ GÓGOL, op. cit., p. 62.
} 
como cortar caminho para a sua cova ${ }^{496}$ ) e com um urso (Agarrou-me, o urso maldito, com suas manoplas de ferro e ainda me empurrou! ${ }^{497}$ ).

Vários personagens chamam diretamente o cabeça do diabo. É importante lembrar o poder da palavra na obra do escritor: "Uma imagem capturada em uma palavra ou em uma unidade sintática, às vezes, define a inteira composição da obra literária, sendo uma síntese artística ou um símbolo generalizado ${ }^{498, " ~ E m ~ G o ́ g o l, ~ a ~ p a l a v r a ~ p r o n u n c i a d a ~ p o d e ~ o b t e r ~ u m a ~}$ forma real. Sofrónova explica que, nas novelas, “existe um inteiro conjunto dos personagens das narrativas populares mitológicas. É preciso notar que o escritor coloca alguns deles nos microepisódios ou nas comparações, deixando, atrás de uma pessoa, um nome, e atrás dos personagens demoníacos, uma função ${ }^{499}$ ". É possível pensar que as alcunhas do cabeça, como diabo zarolho ${ }^{500}$, Satanás zarolho ${ }^{501}$, e, inclusive, o seu próprio apelo ao filho como criatura do diabo ${ }^{502}$, podem servir como indicadores adicionais ao seu caráter infernal, à sua ligação com o mundo alheio.

Mesmo um personagem cômico, o cabeça, como um verdadeiro vilão gótico, é um tirano na sua aldeia: Na reunião dos moradores, ou congregação, apesar do fato de seu poder ser limitado a poucos votos, o chefe sempre toma as decisões e quase que por vontade própria manda quem ele quiser para nivelar e aplainar a estrada ou cavar os fossos ${ }^{503}$. $\mathrm{O}$ cabeça é sombrio, severo e não gosta de falar muito - assim como os outros vilões, Bassavriuk e o feiticeiro. Finalmente, uma inclinação do cabeça às aventuras amorosas, o interesse pelas moças jovens, podem ser vistos como mais uma alusão, embora em forma paródica, a sexualidade insaciável de um vilão gótico.

A namorada do protagonista, Ganna, é a personagem mais misteriosa da novela. No conflito entre Levkó e o pai dele, ela deveria estar ao lado do seu amor e resistir fortemente os avanços do cabeça. Mas, na cena em que Levkó está escutando o diálogo entre a moça e o cabeça, Ganna responde ao velho de um modo, pelo menos, estranho: Você está mentindo; você está me enganando; você não me ama; eu nunca vou acreditar que você me ama! ${ }^{504} \mathrm{Faz}-$ se possível pressupor um relacionamento, pelo menos no passado distante, ou até místico, entre Ganna e o pai de Levkó.

\footnotetext{
496 GÓGOL, 1976, tomo I, p. 69.

${ }^{497}$ Idem, Ibidem, p. 71.

498 VINOGRÁDOV, 1976, p.53.

${ }^{499}$ SOFRÓNOVA, 2010, p. 10.

${ }^{500}$ GÓGOL, op. cit., p. 67,

${ }^{501}$ Idem, Ibidem, p. 73.

${ }^{502}$ Idem, Ibidem, p. 78.

${ }^{503}$ Idem, Ibidem, p. 61.

${ }^{504}$ Idem, Ibidem, p. 63.
} 
Existe uma hipótese de que Ganna e a pánnotchka são a mesma personagem e que nos parece produtiva. Se, em A Terrível Vingança, a heroína possui uma existência dupla - no mundo real e no mundo dos sonhos, em Uma noite de maio, existem as duas heroínas, salvas e protegidas pelo mesmo herói - Levkó. Curiosamente, Ganna e a pánnotchka têm muitas feições em comum. Ambas são muito bonitas e pálidas, ambas são mencionadas em relação à água. Ganna: meu peixinho ${ }^{505}$. Pánnotchka: não consigo nadar levemente, livre, como um peixe $^{506}$. Os olhos de ambas são comparados as estrelas. Ganna tem uma mãe severa, pánnotchka tem uma madrasta cruel. Segundo Gontcharov, "Ganna é comparada a filha do sótnik, o que, no sistema dos outros sinais a identifica com a moça afogada ${ }^{507,, ~ e ~ a i n d a: ~}$ “Levkó não pode se casar com Ganna enquanto não liberar a sua alma. Liberando a sua alma no mundo alheio, ele assim a libera neste mundo ${ }^{508}$ ".

Como é possível observar, o sistema dos personagens, em Uma noite de maio, é complexo por causa do paralelismo dos enredos fantástico e real. Ambos os antagonistas - a bruxa e o cabeça - possuem as feições góticas, mas, ao mesmo tempo, não perdem uma ligação com o substrato popular: a bruxa pode ser vista também como uma personagem folclórica das bylítchki, e o cabeça tem muitas peculiaridades em comum com o diabo do teatro popular de vertep. As heroínas parecem representar, na novela, a mesma personagem, uma donzela em perigo. A salvação de uma das moças conduz o herói a uma salvação da outra. O protagonista cumpre, na novela, um papel de um mediador entre os dois mundos, um embaixador e um verdadeiro herói. A punição do cabeça pelo comissário é um desenlace lógico do enredo real, que não poderia existir sem o desenlace feliz no mundo mágico.

Em A Carta Perdida, a oposição existe entre o herói - um cossaco sem nome, que no decorrer da novela é chamado de "avô", e a imagem coletiva e grotesca - "a tribo diabólica" do inferno, que merece a nossa atenção especial, porque é descrita por meio de uma narração “fragmentária”, típica para a maneira artística de Gógol. O vilão, na novela, é um monte sem rosto, de que emergem alguns elementos como pernas, mãos, caretas etc. Desde o seu primeiro encontro com o protagonista, ainda no mundo real, na taberna, os membros da tribo são referidos de um modo sinedóquico, quando as partes do corpo separadas significam a criatura inteira $^{509}$. Esse procedimento é aplicado já no primeiro encontro do avô com a força

\footnotetext{
505 GÓGOL, 1976, tomo I, p. 55.

${ }^{506}$ Idem, Ibidem, p. 76, grifo nosso.

${ }^{507}$ GONTCHAROV, 1991, p. 27.

${ }^{508}$ Idem, Ibidem, p. 29.

${ }^{509}$ PUTNEY, 1999, p. 149.
} 
impura, ainda no palheiro da taberna: E lhe afigurava que atrás da carroça vizinha algo cinza exibia os cornos... ${ }^{510}$.

Na floresta encantada, a tribo é vista pelo avô, no início, como as pessoas. Como diz o pesquisador Holquist, em Gógol, há dois pontos que caracterizam os diabos e as bruxas: primeiro, é possível achá-los em qualquer lugar; segundo, eles são capazes de mudar a aparência, mas é fácil distingui-los das pessoas, pelo menos, por meio dos motivos do seu comportamento $^{511}$. Na cena na floresta, de novo, nenhum dos diabos é mostrado por completo - as partes dos seus corpos estão surgindo em frente do herói em luz de uma fogueira, fraca e pouco confiável: Só agora enxergara que ao lado do fogo eram pessoas, com carrancas tão belas que em outros tempos daria Deus sabe o quê para se esquivar deste encontro ${ }^{512}$. Uma mancha da luz destaca somente alguns detalhes. Na tradição do gótico, a escuridão é usada para criar o jogo com a luz, às vezes, definido como a "iluminação de Rembrandt" - o pintor holandês cuja técnica mostra um contraste muito grande com a iluminação da tela, o que confere grande dramaticidade às pinturas. A falta de iluminação, nas cenas, faz os personagens menos definidos, assustadores para o protagonista.

As "carrancas" são sombrias e agressivas. O contato entre o herói e o "vilão" é estabelecido somente no momento em que o cossaco joga o dinheiro no fogo - um rito mágico, talvez relacionado ao folclore eslavo. Nessa cena, já começa a transformação do vilão, são usadas as metáforas ferinas: As carrancas apuraram os ouvidos e estenderam as manoplas $^{513}$. Depois desse gesto, o avô é transferido para o inferno, onde as "carrancas" assumem as suas formas verdadeiras. Dessa vez, o efeito de sinédoque é reforçado, e, em vez das partes do corpo humano, aparecem partes do corpo dos animais: Focinhos de porcos, bodes, grous, cavalos - todos se esticaram e agorinha mesmo faziam de tudo para beijá-lo ${ }^{514}$. O narrador não somente chama a nossa atenção para os fragmentos do corpo: essas criaturas demoníacas são "construídas" dos componentes específicos dos corpos multifários. O avô vê os diabos com seus focinhos, de pernas alemãs, virando os rabos ${ }^{515}$. Entre eles, são os músicos que não precisam dos instrumentos porque usam os próprios corpos para tocar: os músicos batiam as suas bochechas com os punhos fechados como em pandeiros e com os

\footnotetext{
${ }^{510}$ GÓGOL, 2014, p. 99.

${ }^{511}$ HOLQUIST, 1967, p. 355.

${ }^{512}$ GÓGOL, op. cit., p. 101.

${ }^{513}$ Idem, Ibidem, p. 101.

${ }^{514}$ Idem, Ibidem.

${ }^{515}$ Idem, Ibidem.
} 
narizes sopravam feito trompas ${ }^{516}$. Posteriormente, Gógol usa esse procedimento em abundância - as partes do corpo viram objetos, e os objetos tornam-se as partes do corpo - um exemplo mais típico, o nariz que começa a andar pelas ruas de Petersburgo.

Apesar do seu caráter fragmentário, a tribo impura, em A Carta Perdida, pode ser vista como algo íntegro, uma força má contra o cossaco solitário. Os diabos e as bruxas são elusivos, o herói não consegue apanhar e atacá-los. Antes de se persignar, o cossaco parece uma boneca dirigida pelas mãos da tribo. Um cossaco valente, com a força e o apetite de bogatir (puxou uma tigela com toucinho cortado e um pernil, pegou um garfo um pouco menor que os forcados com os quais o mujique colhe $f e n o^{517}$ ), ele é possuido pelas forças impuras, não consegue controlar os seus movimentos, e a comida vai para a boca de alguém invisível. Assim como os outros heróis das novelas gogolianas, ele é assustado pelos fenômenos fantásticos. A vitória da personagem acontece somente com a ajuda da cruz; mesmo assim, os diabos não são vencidos por completo. $\mathrm{O}$ avô perde o cavalo, e quando volta a casa, está coberto de sangue, e a sua mulher é possuida por algum feitiço que a faz dançar. Nesse sentido, sua vitória parece incompleta e até ilusória.

O mal como força sempre está presente no mundo gogoliano. O diabo pode assumir formas diferentes, mas sempre se destacam, no vilão, as seguintes feições: ele é um forasteiro, sombrio e agressivo, possui algo estranho na aparência ou no caráter. É possível dizer que a imagem do mal, em Gógol, há várias confluências, entre as quais estão o folclore eslavo, a ortodoxia, o romantismo alemão e, sem dúvida, a tradição do gótico.

\footnotetext{
${ }^{516}$ GÓGOL, 2014, p. 101.

${ }^{517}$ Idem, Ibidem, p. 102.
} 


\title{
Gótico literário, arquitetura e artes plásticas: pontos de comparação.
}

\section{Transformação das imagens da arquitetura e pintura em Noites em uma granja perto de Dikanka - temas recorrentes e figuras da linguagem}

\begin{abstract}
Ao entrar na escuridão sagrada desse templo, através do qual fantasticamente está olhando a luz multicor das janelas, elevando os olhos para, onde se perdem, cruzando, as abóbadas ogivais uma em cima da outra, uma em cima da outra, e não há fim delas, - é muito natural sentir na alma o terror involuntário da presença da relíquia que a mente audaciosa do homem nem ousa tocar $^{518}$.
\end{abstract}

(Nikolai Gógol, Sobre a Arquitetura de hoje, 1831)

Muitos pesquisadores do romance de terror consideram o estilo gótico na arquitetura e nas artes plásticas como uma grande fonte de inspiração para esse gênero literário, entre eles Ernest Baker ${ }^{519}$, Linda Bayer-Berenbaum ${ }^{520}$ e David Punter ${ }^{521}$. Apesar do estilo gótico, na arquitetura, existir desde os anos 1100, o termo para descrevê-lo é muito mais recente. Ele era aplicado, em primeiro lugar, para mostrar o desprezo que os ingleses sentiam com relação à predileção dos europeus pelas obras arquitetônicas medievais. Antes da segunda metade do século XVIII, tal tipo de arquitetura era considerado bárbaro e ridículo. O renascimento do estilo medieval começou com Horace Walpole e os seus contemporâneos que confessaram afeto pelo assim chamado gótico, mesmo que entendessem pouco de sua verdadeira natureza $^{522}$. Foram atraídos pela irregularidade, ornamentação inabitual, imensidão dos edifícios góticos que dominavam por completo o olhar, e admiravam a amplidão que sugeria divindade e infinitude. A idade e a durabilidade dos prédios também evocavam, nos apreciadores, o sentimento do sublime. Segundo o estudioso Gíppius, o intenso interesse pela arquitetura e pelo estilo gótico era também muito característico na Rússia da época de Gógol $^{523}$.

O gótico, com seu exagero dos elementos artísticos, engenhosidade e excesso, era um desafio para o ascetismo clerical. Era uma aspiração instintiva ao mundo natural, em certo sentido, era uma revolta. Ao mesmo tempo, o gótico, como um fenômeno da arquitetura,

\footnotetext{
${ }^{518}$ GÓGOL, N.V. Ob arkhitekture nynechnego vrémeni. In GÓGOL, 1952, tomo 8. Moskvá - Leningrad: AN SSSR, 1952. p.57.

${ }^{519}$ BAKER, 1942.

${ }^{520}$ BAYER-BERENBAUM, 1982.

${ }^{521}$ PUNTER, David. A companion to the Gothic. Oxford: Blackwell Publishing, 2000.

${ }^{522}$ BAKER, op. cit. p. 175.

${ }^{523}$ GÍPPIUS, V.V. Gógol. In GONTCHAROV, S.A. (org.).Gógol: Pro et Contra. Tomo I. Sankt-Peterburg: Rússkaia khristiánskaia gumanitárnaia akadémia, 2009. p. 619.
} 
conservou, nas suas imagens plásticas, o caráter fantástico da época medieval, os monstros da imaginação dos fiéis. Tanto o céu quanto o inferno nunca estiveram tão palpáveis, e isso atraía muito os autores do século XVIII, cansados do racionalismo e das fronteiras que a sociedade lhes impunha.

$\mathrm{Na}$ opinião de Bayer-Berenbaum, o gótico, na arte, assim como na literatura, expressava "uma perspectiva estética e filosófica coerente", na qual "paralelos diretos podem ser traçados entre as técnicas góticas na arte e na literatura ${ }^{524,}$. Concordamos com essa ideia: é possível dizer que, no seu sistema figurativo, o gótico literário, parcialmente, emprestava as ideias das imagens do gótico arquitetônico.

O tema da arte é um dos mais importantes para Gógol e, talvez, o mais problematizado pelo escritor: ele acreditava que a arte podia mudar o mundo, e, por isso, a tratava com muita exigência. Além disso, Gógol era um grande admirador da arquitetura gótica e dedicou seu artigo "Sobre a Arquitetura de hoje" à comparação da arquitetura do seu tempo com os edifícios em estilo gótico. Em sua opinião, a arquitetura gótica, aquela arquitetura gótica que se formou antes do fim da Idade Média, é um fenômeno que o gosto e a imaginação do homem nunca tinham produzido antes ${ }^{525}$, e o estilo gótico dava mais liberdade de expressão ao artista: A inspiração se dirige na altura com mais vida e ardor que na largura ${ }^{526}$. Isso nos leva a procurar várias analogias entre os temas recorrentes, as figuras de linguagem, na obra gogoliana, e as feições do estilo gótico na arquitetura.

Para simplificar a nossa tarefa, tentaremos destacar alguns elementos arquitetônicos góticos mais importantes e desenvolver uma hipótese - o que cada um deles poderia trazer para a poética literária. Em nossa opinião, os elementos cruciais são a abóbada e as paredes da catedral, a ornamentação, os vitrais e as esculturas monstruosas.

\footnotetext{
${ }^{524}$ BAYER-BERENBAUM, 1982, p. 47.

${ }^{525}$ GÓGOL, 1954, tomo 8. p. 57.

${ }^{526}$ Idem, Ibidem, p. 65.
} 
Tabela 1. Correlação entre o estilo gótico na arquitetura e na literatura.

\begin{tabular}{|l|l|}
\hline Arquitetura & Literatura \\
\hline $\begin{array}{l}\text { Abóbada e paredes: diminuem a pessoa, } \\
\text { fazendo com que se sinta insignificante diante } \\
\text { da grandeza das forças superiores. }\end{array}$ & $\begin{array}{l}\text { Na linguagem: metáforas arquitetônicas nas } \\
\text { descrições das paisagens. }\end{array}$ \\
\hline $\begin{array}{l}\text { Ornamentação: complexa, sofisticada, } \\
\text { imprevisível, representa o caráter engenhoso } \\
\text { do estilo. }\end{array}$ & $\begin{array}{l}\text { Na poética: o tema do labirinto; o tema do } \\
\text { Na linguagem: a estrutura complexa, mas } \\
\text { "voadora", da frase, períodos longos. }\end{array}$ \\
\hline $\begin{array}{l}\text { Esculturas: imagens monstruosas nos } \\
\text { telhados das catedrais que representam os } \\
\text { espíritos malignos. }\end{array}$ & $\begin{array}{l}\text { Na poética: o efeito do grotesco, tendência } \\
\text { ao excesso e exagero nas descrições das } \\
\text { personagens. }\end{array}$ \\
\hline $\begin{array}{l}\text { Vitrais: os tons contrastantes representam a a poética: efeito de contraste nos níveis da } \\
\text { duplicidade do mundo, dividido entre o céu e } \\
\text { o inferno. }\end{array}$ & $\begin{array}{l}\text { Nomposição, das personagens, dos objetos e } \\
\text { da paisagem. } \\
\text { Na linguagem: metáforas de cor, que } \\
\text { também entram em contraste e servem como } \\
\text { uma característica adicional às personagens. }\end{array}$ \\
\hline
\end{tabular}


Desde o seu início, a abóbada e as paredes góticas eram designadas para criar uma experiência inusual para aqueles que adentravam a catedral, criando, nos fiéis, um efeito de transformação espiritual, isto é, o sentimento ambíguo de deleite e pavor.

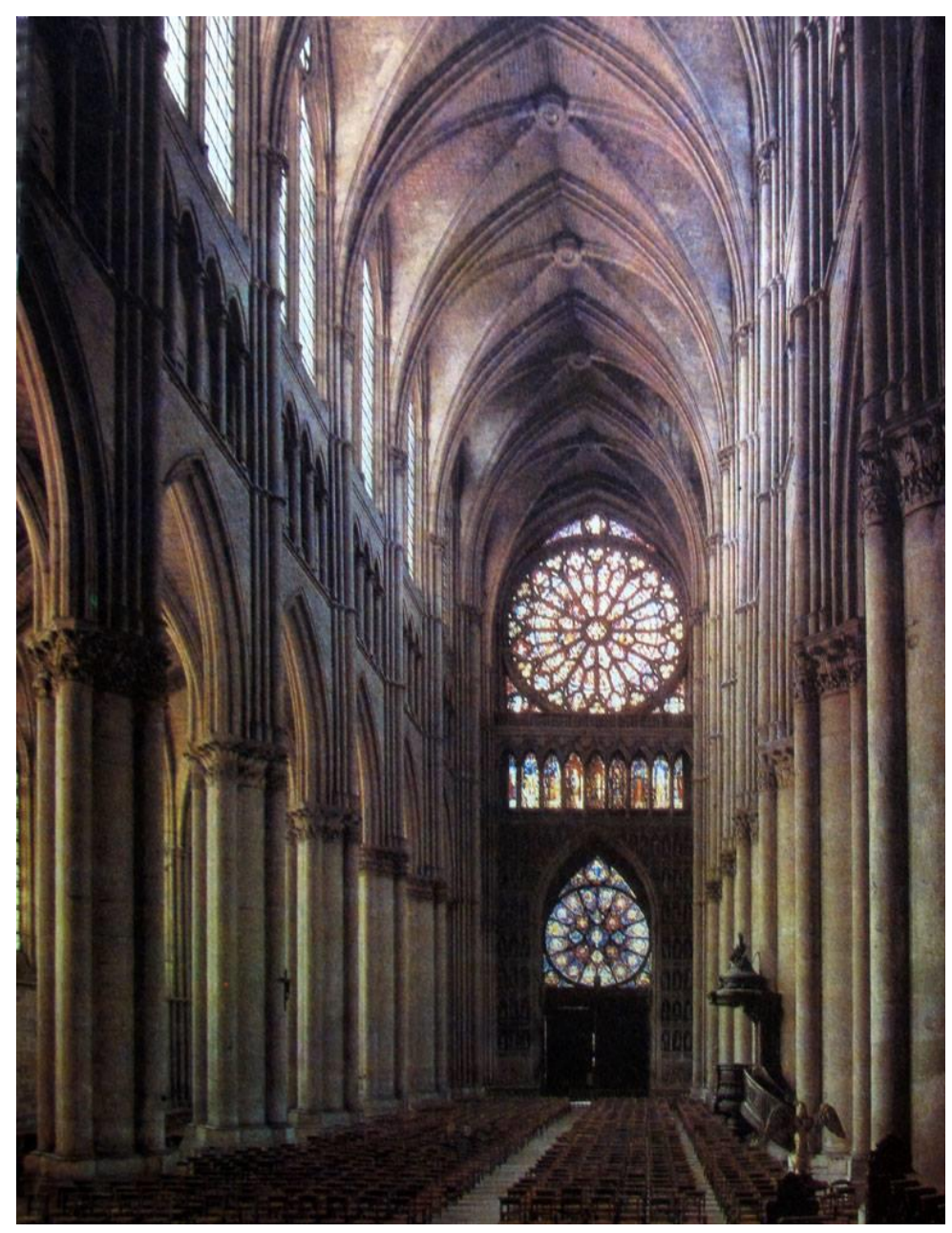

O interior da catedral de Notre-Dame de Reims, construída no século XIII ${ }^{527}$.

Sua altura e proporções monstruosas diminuíam a pessoa, fazendo com que se sentisse insignificante diante da grandeza das forças superiores. Isso mudava a percepção normal do espectador e distorcia a imagem que o cercava, gerando nele uma forte emoção. O historiador da arte, Ernst Gombrich, assim descreve o ambiente das catedrais:

As novas catedrais propiciavam aos fiéis o vislumbre de um mundo diferente. Eles teriam ouvido falar, em sermões e cânticos, da Jerusalém Celestial com seus portões de pérolas, suas joias de incalculável preço, suas ruas de ouro puro e cristal transparente (Apocalipse, XXI). Essa visão tinha descido agora do céu à Terra. As paredes das novas igrejas não eram

${ }^{527}$ TIAJIÓLOV, V. N. Isskusstvo srédnikh vekov. Moskvá: Izobrazítel'noe isskússtvo, 1993. p. 52. 
formadas de vitrais policromos que refulgiam como rubis e esmeraldas. Os pilares, nervuras e rendilhados despediam cintilações douradas. Tudo que era pesado, terreno ou trivial fora eliminado. Os fiéis que se entregavam à contemplação de tanta beleza podiam sentir que estavam mais próximos de entender os mistérios de um reino afastado do alcance da matéria ${ }^{528}$.

No nível da poética do gótico literário, o efeito de transformação espiritual tornou-se o tema do castigo divino e da onipotência, às vezes, cruel e sinistra, de Deus. O interior da catedral procura enfatizar a humildade dos seres humanos. $\mathrm{O}$ espectador sente-se à mercê dos poderes sobrenaturais - um sentimento inquietante que persegue também a vítima na novela gótica. Um excelente exemplo é a cena da fuga do feiticeiro em A Terrível Vingança. Como dentro da catedral, o vilão não consegue esconder-se do olhar divino, segue sua jornada desesperada pelas montanhas de Cárpatos, e o leitor se sente apavorado com o julgamento divino: Como um trovão, se espalhou esse riso selvagem pelas montanhas e ressoou no coração do feiticeiro, fazendo-o tremer $^{529}$.

Em A noite da véspera do dia de Ivan Kupala, o tema do castigo divino é revelado pela cena de enlouquecimento do protagonista:

Asselvajou-se, ficou peludo, feio, o tempo todo pensando na mesma coisa, se esforçando para lembrar alguma coisa, e fica com raiva e rancor por não conseguir. Muitas vezes se levanta ferozmente do seu lugar, agita os braços, crava seus olhos em algo como se quisesse apanhá-lo; os lábios se movem como se quisessem pronunciar alguma palavra há muito tempo esquecidae param imóveis... A fúria o domina; como um demente, rói e morde suas mãos e, por despeito, arranca as madeixas do cabelo, até que, ao se aquietar, cai, como que em delírio, e depois de novo começa a lembrar, e de novo a fúria, e de novo o tormento... Que desgraça divina é esta? ${ }^{530}$

No nível da linguagem, o efeito da transformação espiritual está visível em algumas descrições da natureza. Rios, bosques e montanhas são parecidos com as paredes e as abóbadas das catedrais góticas. Por exemplo, em A Terrivel Vingança, uma descrição do rio Dnepr é elevada e sublime e parece uma verdadeira obra arquitetônica:

\footnotetext{
528 GOMBRICH, E.H. A História da Arte. 15. ed. Tradução de Álvaro Cabral. Rio de Janeiro: Editora Guanabara Koogan, 1993. p. 141.

${ }^{529}$ GÓGOL, 1990, p. 80.

${ }^{530}$ GÓGOL, 1976, tomo I, pp. 50-51. Observação importante: quem pune o herói é sempre Deus, de acordo com os pecados da personagem.
} 
É encantador o Dnepr quando o tempo é sereno, quando solto e fluído lança por entre bosques e montanhas suas águas plenas. Não rumoreja, nem ressoa. Ao contemplá-lo não se sabe se flui ou não flui em sua majestosa largura, e parece que todo ele é feito de cristal, como se um caminho azul e espelhado, desmedido na largura, infinito no comprimento, ondulasse e serpentasse pelo verde mundo. Então, é agradável para o sol ardente olharse das alturas e mergulhar os raios no frio de suas águas cristalinas e também para as florestas ribeirinhas refletirem-se brilhantes nas suas águas! !31

Observa-se uma abundância de adjetivos de cor e luz que trazem associações com vitrais: cristal, azul, espelhado, verde, cristalinas, brilhantes. Elas dão ao Dnepr uma impressão de leveza e transparência, e também de inconstância, volubilidade (não se sabe se flui ou não flui). O mundo inteiro é refletido nas suas águas como em um grande espelho uma universalidade característica também da catedral gótica, que, frequentemente, foi comparada com o mundo em miniatura.

Uma descrição renomada de Uma noite de maio - que começa com as palavras Vocês conhecem a noite ucraniana?, também destaca uma impressão de leveza, porém encanta mais o leitor com sua imensidão. Dessa vez, Gógol compara o céu com a abóbada da catedral mundial:

A imensa abóbada celestial alarga-se e abre-se ainda mais imensa. Ela arde e respira. A terra inteira está repleta desse brilho prateado e o ar maravilhoso é refrescante e morno, cheio de volúpia, um oceano de aromas palpita. Uma noite divina! Uma noite encantadora! Os bosques erguem-se imóveis, misteriosos, cheios de escuridão e se lançam em sombras enormes. São quietos e tranquilos esses lagos; o frio e a escuridão de suas águas estão encarcerados, sombrios nas paredes verde-escuras dos jardins. [...] Toda a paisagem dorme. Mas, em cima, tudo respira, tudo é maravilhoso, tudo é solene. E a alma está plena de liberdade e maravilhada, e visões prateadas emergem, em harmonia, de suas profundezas. Uma noite divina! Uma noite encantadora! ${ }^{532}$

Como se pode observar nesse trecho, Gógol usa, em abundância, as metáforas não apenas arquitetônicas, mas relacionadas à arquitetura gótica: "a imensa abóbada celestial", "os bosques erguem-se imóveis, misteriosos, cheios de escuridão", "paredes verde-escuras". As impressões que Gógol quer provocar no leitor são parecidas com as descrições da catedral gótica. A parte mais importante do edifício é a abóbada: "No interior de uma catedral gótica somos levados a compreender a complexa interação de trações e pressões que mantém a

\footnotetext{
${ }^{531}$ GÓGOL, 1990, p. 69.

${ }^{532}$ Idem, 1976, tomo I, pp. 59-60.
} 
grandiosa abóbada em seu lugar. Não existem paredes cegas ou pilares maciços em parte alguma ${ }^{533}$. Em Gógol o lugar da abóbada é tomado pelo céu.

A ornamentação gótica é, frequentemente, descrita como violenta e antinatural, porque suas linhas não fluem ritmicamente e organicamente da frente para trás.

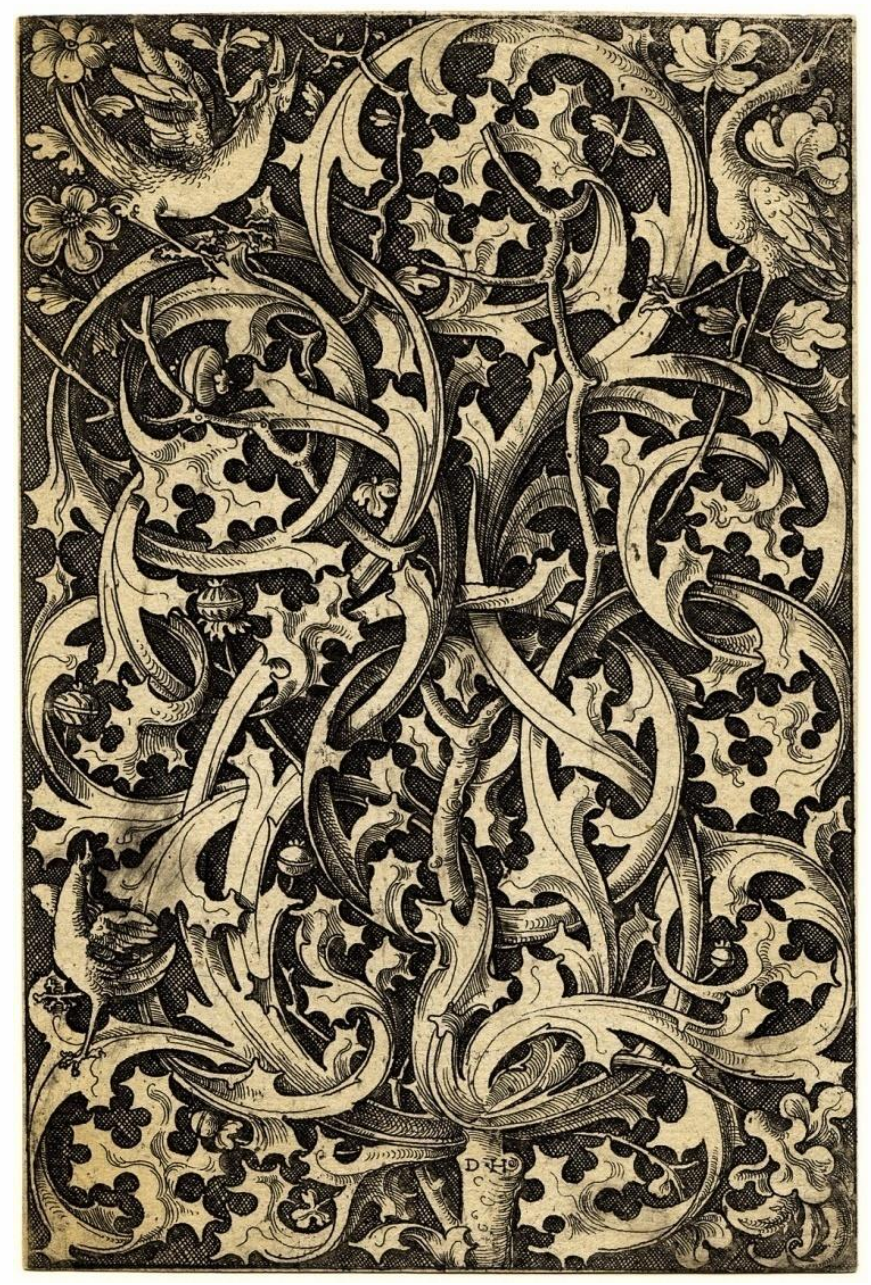

Hopfer, Daniel (acerca de 1470-1536): Ornamento gótico com cardo. Gravura a água forte ${ }^{534}$.

O caráter sofisticado e requintado do ornamento gótico, na literatura, está parcialmente refletido no tema do labirinto, que pode ser artificial ou natural. Na poética gogoliana, prevalece o labirinto natural. Iúri Mann salienta que a imagem do labirinto, que pode ser considerado um símbolo de uma corrida no mesmo lugar, e que une em si as qualidades do

\footnotetext{
${ }^{533}$ GOMBRICH, 1993, p. 140.

${ }^{534}$ Diponível em: <https://commons.wikimedia.org/wiki/File:Ornament_with_Thistle_(Gothic Thistle).jpg >. Acesso em: 6 jul. 2015.
} 
estático e dinâmico, nas margens do mundo artístico de Gógol, é uma das formas mais importantes de modelação do espaço ${ }^{535}$. Extremamente importante também para o romance gótico, o labirinto chegou a ser associado ao medo, à confusão e à alienação ${ }^{536}$. O labirinto é um topos do "lugar encantado". Ele é também sinonímico à morte: a morte corta uma pessoa para sempre do resto do mundo terrestre, leva-a a uma solidão total, absoluta. Assim, o labirinto também é um local onde uma pessoa está completamente sozinha, não consegue achar uma saída. Os bosques densos, nos quais se perdem os heróis, têm muito em comum com os labirintos. A imagem do labirinto é crucial no sistema artístico de Gógol.

O próprio Gógol sentia a conexão entre a natureza selvagem do bosque e o estilo gótico. Escreveu, apenas um ano após a publicação de Noites em uma granja, que a arquitetura gótica possui a marca de um bosque com os galhos entrelaçados, onde um machado não batia por séculos. Esses ornatos, dirigindo-se em linhas intermináveis, e as redes de entalho transparente não são outra coisa senão uma lembrança escurecida de troncos, galhos e folhas das árvores ${ }^{537}$.

As descrições de bosques, em Noites, desafiam as nossas primeiras impressões; ao lado deles, os heróis se sentem fracos, perdidos, inquietos. Em A Terrível Vingança, a primeira descrição de bosque aparece na cena da volta de pan Danilo com sua esposa para casa, depois da aparição do feiticeiro na festa do casamento: Aqueles bosques nas colinas, não são bosques: são cabelos que cresceram na cabeça eriçada do senhor dos bosques. Sua barba banha-se na água e sob a barba e sobre os cabelos está o céu profundo ${ }^{538}$. A paisagem, nesse trecho, corresponde aos pensamentos preocupados das personagens. A segunda menção ao bosque, na novela, é ligada à loucura da heroína, que tinha perdido seu marido e sua criança. Ela perambula no bosque como num labirinto - assim como o observador da ornamentação gótica se perde nas suas linhas: Naquela hora em que se apaga o crepúsculo, ainda não brilham as estrelas e nem arde a lua, mas já é assustador andar pelo bosque, as crianças sem batismo agarram-se às árvores e seguram-se nos ramos, soluçam, dão gargalhadas ${ }^{539}$.

Em A noite da véspera do dia de Ivan Kupala, o herói também se perde na floresta na sua procura da flor de samambaia. Sua penetração gradual no Medvéji Ovrag é conectada, na

\footnotetext{
${ }^{535}$ MANN, Iú. V. Vstrétcha v labirinte (Frants Kafka i Nikolai Gógol”). In Vopróssy literatury, 1999, n. 2. p. 170.

${ }_{536}$ BOTTING, 1996, pp. 80-81.

${ }^{537}$ GÓGOL, 1954, tomo 8. pp. 64-65.

${ }^{538}$ GÓGOL, 1990, p. 46, grifo nosso.

${ }^{539}$ Idem, Ibidem, p. 76.
} 
novela, ao tema da alma perdida. A descrição da paisagem segue o mesmo padrão de presente em A Terrivel Vingança - o escritor mostra os perigos que cercam as personagens: De mãos dadas, eles se enfiaram pelos pântanos lamacentos, emaranhando-se nos abrunheiros que cresciam densamente e tropeçando quase a todo passo ${ }^{540}$. Nesse caso, a natureza tenta resistir às intenções impuras dos heróis.

Em Uma noite de maio, a descrição do bosque é associada ao poder do tempo. As árvores que cercam a casa abandonada do sótnik a destroem:

Ao lado do bosque, num morro, cochilava uma velha casa de madeira com contraventos fechados; o musgo e a erva daninha cobriam seu telhado; macieiras frondosas haviam crescido em abundância diante de suas janelas; o bosque, envolvendo-a com sua sombra, conferia-lhe um aspecto soturno e selvagem; um nogueiral estendia-se junto a sopé dele e descia ao lago ${ }^{541}$.

Em A Carta Perdida, o herói faz uma jornada ao inferno através do bosque. Ele serve como uma fronteira mágica entre dois mundos: $O$ abrunheiro vai te arranhar, a densa aveleira irá obstruir o seu caminho - mas você deve continuar; e quando chegar a um pequeno rio, só então poderá parar. Ali você vai ver quem precisa; só não se esqueça de encher os bolsos com aquilo para que os bolsos são feitos ${ }^{542}$.

Essas jornadas dos heróis gogolianos, nos bosques, correspondem à visão simbólica do bosque na literatura gótica. Conforme nos informa Vatsuro, "a floresta densa, com os atalhos perdidos, contendo perigo, mas, às vezes, dando refúgio, é uma alegoria tradicional de uma vida-peregrinação pelos caminhos de ilusões, em que os únicos guias confiáveis são a virtude e a fé na providência"543. Dez anos depois da publicação das novelas ucranianas, Gógol repetiria essa imagem da floresta-labirinto nas suas Almas Mortas:

Que caminhos tortuosos, obtusos, estreitos, impraticáveis, caminhos que a desviavam para longe, escolheu a humanidade, na ansia de atingir a verdade eterna, quando diante dela se descortinava uma estrada ampla e reta como o caminho que leva ao santuário magnifico designado para a morada do rei! Era um caminho mais largo e mais suntuoso que todos os outros caminhos, inundado de sol e iluminado por fogos a noite inteira mas os homens passavam ao largo dele, mergulhados em trevas espessas. E

\footnotetext{
${ }^{540}$ GÓGOL, 1976, tomo I. p. 43.

${ }^{541}$ Idem, Ibidem, p. 57.

${ }^{542}$ Idem, 2014, p. 100.

${ }^{543}$ VATSURO, 2002, p. 131.
} 
quantas vezes, já levados para ele pela providência divina, ainda assim eles conseguiam desviar-se e perder-se, conseguiam em plena luz do dia, afundar-se novamente, cegar de fumaça os próprios olhos, e, arrastando-se no encalço de fogos-fátuos, conseguiram, enfim, chegar até à beira do abismo, para depois, cheios de terror, perguntarem uns aos outros: onde está a saída, onde está o caminho? ${ }^{544}$

A outra reflexão do ornamento gótico, nos enredos literários, é, provavelmente, o tema do destino. O ornamento gótico, com suas curvas imprevisíveis e sua força de movimento tenta superar todos os obstáculos para achar o caminho para o novo movimento. As personagens do romance gótico também estão procurando, desesperadamente, a saída de uma situação difícil e perigosa, estão tentando lutar com o seu destino injusto. Como é uma tarefa muito difícil, os heróis, frequentemente, sentem desespero irresoluto, rendição diante de circunstâncias de força maior.

As novelas de Noites em uma granja não têm enredos muito desenvolvidos, embora concordemos com a opinião de Andréi Bélyi de que o enredo de Gógol "não cabe nos limites

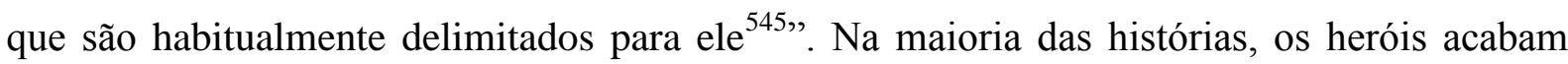
sendo infelizes porque não conseguem superar os obstáculos. As novelas geram uma impressão de impossibilidade de lutar contra as dificuldades.

Os heróis e as heroínas de Noites tentam lutar contra seu destino, mas não têm sucesso: qualquer passo em direção a alguma mudança acaba sendo trágico para eles. Assim, a família inteira de Danilo, de A Terrivel Vingança, cai vítima do feiticeiro malévolo. O próprio feiticeiro também é uma vítima: ele não entende as razões dos seus crimes horrendos, e uma tentativa de pedir salvação em contrição gera uma nova cadeia de crimes, ainda mais pesados. Petró, de A noite da véspera do dia de Ivan Kupala, vende sua alma ao diabo porque ele é pobre, e não lhe é permitido casar com sua namorada; acaba se casando com ela, mas não encontra felicidade, e logo é destruído pelo fogo infernal. A pánnotchka, de Uma noite de maio, se afoga no lago pela crueldade de sua madrasta. Não consegue se vingar até depois da sua morte, só com a ajuda de Levkó ela consegue derrotar a bruxa. A única exceção é $A$ Carta Perdida, com um final verdadeiramente feliz, porque é mais próxima ao folclore eslavo do que as demais novelas aqui analisadas. Mas, se observar o texto com mais atenção, pode-se perceber a presença do mal no final de A Carta Perdida também. Nessa novela, o mal é mostrado através dos eventos inexplicáveis. Em casa do cossaco, aparentemente, para castigá-lo por ter demorado para benzer a casa, todo ano, na mesma época, a baba passava

${ }_{544}^{54}$ GÓGOL, N.V. Almas mortas. Trad. de Tatiana Belinky. São Paulo: Abril Cultural, 1979. pp. 251-252. ${ }^{545}$ BÉLYI, 2009, p. 313. 
por tanta coisa esquisita que a forçava dançar, e isso é tudo. Nem começava a fazer algo que as pernas intentavam outra coisa, e assim lhe obrigavam a cair na prisiádka ${ }^{546}$.

Como mencionamos no item anterior, Andréi Bélyi foi um dos primeiros pesquisadores a perceber o caráter profundamente trágico das novelas ucranianas. Segundo ele, o tema principal de Noites é o conflito entre a personalidade individual e o clã, limitado ao seu mundo pequeno. Parcialmente concordando com Bélyi, precisamos acrescentar que o tema do clã representa o tema mais importante para a coletânea - a tragédia do destino. Podem-se ver os ecos desse tema nas outras novelas da coletânea - em A noite da véspera do dia de Ivan Kupala, Uma noite de maio, nas quais, de um jeito ou de outro, se manifesta o problema do destino individual, a tentativa de ser feliz apesar de todas as dificuldades.

No nível da linguagem, o ornamento gótico é, parcialmente, imitado na estrutura da frase gogoliana. Parecida com a fala popular, ela consiste em períodos longos que são continuados por outros, ainda mais sofisticados (as orações repetindo o princípio descrito na epígrafe do presente capítulo - uma em cima da outra, uma em cima da outra, e não há fim delas), mudando por completo o pensamento do leitor e dirigindo-o em uma nova direção inesperada: “as frases se encadeiam não exatamente pela lógica do discurso, mas segundo um princípio de expressividade do discurso, uma espécie de 'semântica sonora' irreverente ${ }^{547 \text { ", }}$ Arlete Cavaliere salienta, no plano da linguagem de Gógol: "Há em seus textos uma sucessão, quase alucinada, de diferentes tons que passam subitamente do melodramático e do sentimental para o épico, ou para o absurdo ${ }^{548 \%}$. Essa peculiaridade do estilo gogoliano, que foi observada já por Bélyi ${ }^{549}$, é uma das razões pela qual esse autor é de tão difícil tradução para outros idiomas.

Conforme Irina Kartachova, o caráter sofisticado do estilo gogoliano foi tirado diretamente da arquitetura gótica: como nas catedrais, o peso do material foi vencido por um movimento dos arcos, das abóbadas, das flechas para cima, do mesmo jeito o "peso" das palavras, na obra de Gógol, foi vencido por uma construção impetuosa, "voadora" da frase que parece ser pronunciada em um suspiro ${ }^{550}$. Conforme Eikhenbaum, nos textos gogolianos, há uma tendência de não simplesmente narrar algo, mas quase declamar. As palavras e as orações são escolhidas e conectadas não somente de acordo com o princípio do discurso lógico, mas também seguindo o princípio do discurso expressivo, em que articulação, mímica

\footnotetext{
${ }^{546}$ GÓGOL, 2014, p. 105.

${ }^{547}$ CAVALIERE, 2009, p. 23.

${ }^{548}$ Idem, Ibidem, p. 24.

${ }^{549}$ BÉLYI, Andrei. Gógol. In GONTCHAROV (org.), 2009. pp. 299-312.

${ }^{550}$ KARTACHOVA, 2003, p. 354.
} 
e gestos fônicos cumprem o papel principal. Daí o fenômeno da semântica sonora em sua linguagem: a "embalagem" sonora da palavra, suas características acústicas se tornam, no discurso gogoliano, significantes independentemente do significado lógico ou material ${ }^{551}$.

Vários trechos mostram essa complexidade e sonoridade da frase em Noites. Este procedimento artístico é especialmente visível nas novelas "narradas" pelo diácono Fomá Grigórievitch: A noite da véspera do dia de Ivan Kupala e A Carta Perdida.

Por exemplo, a descrição da bonita heroína Pidorka, em $A$ noite da véspera do dia de Ivan Kupala, no original, é contida em apenas uma (!) oração, mas ao leitor pode passar despercebido devido ao tom elevado que quase parece uma canção:

A tia do meu falecido avô contava (e para uma mulher, como vocês sabem, é mais fácil beijar o diabo, sem maldade, do que chamar outra mulher uma beldade) que as bochechas rechonchudas da cossaca eram rosadas $e$ ardentes como uma papoula cor-de-rosa mais suave, quando, depois de se lavar com o orvalho de Deus, ela brilha, endireita as folhinhas e se apruma perante o sol nascente; suas sobrancelhas eram como as cordas negras (as nossas moças hoje as compram para pendurar as cruzes e os ducados dos moscais que passam pelas aldeias com caixas) que se curvam corretamente, como se mirassem nos seus olhos claros; a sua boca pequena, para a qual os jovens daquele tempo olhavam gulosamente, parecia que fora feita para trinar canções do rouxinol; seu cabelo, negro como as asas de uma graúna e macio como linho novo (naquele tempo as nossas moças ainda não se enfeitavam com tranças finas, entrelaçando-as com fitas estreitas, bonitas e coloridas), caía em forma de caracóis crespos sobre o kontusz bordado de ouro $^{552}$

É possível observar como o pensamento do narrador, passo a passo, "complica" o ornamento da frase, introduzindo novas figuras. Começa com as bochechas rosadas da cossaca, depois seguidas pela imagem de uma papoula e do nascimento do sol. Continua com as sobrancelhas negras parecidas com as cordas que outras moças usavam; os lábios e uma canção de rouxinol; o cabelo e as asas de uma graúna, e assim por diante. Essa imagem não é só um quadro de uma menina bonita, ela é também uma descrição do mundo inteiro contido nela, o mundo de Dikanka e da Maloróssia.

O mesmo efeito artístico, porém menos potente, pode ser visto na outra novela contada por Fomá Grigórievitch, A Carta Perdida. Observamos como o narrador coloca os detalhes que não possuem nenhuma importância ao enredo. Algumas palavras ou nomes parecem uma acumulação absurda de sons, cuja expressividade ocorre no plano acústico, nas repetições e

\footnotetext{
${ }^{551}$ EIKHENBAUM, 1969, p. 309.

${ }^{552}$ GÓGOL, 1976, tomo I, p. 43.
} 
nos trocadilhos. As palavras como que escapam da página e ganham uma vida independente, vivem como as personagens dentro do texto:

O então escrivão regimental, - que o tinhoso o carregue, nem lembro do apelido dele... Viskriák, não é Viskriák, Motúzotchka, não é Motúzotchka, Golopútsek, não é Golopútsek... sei apenas que esse apelido esquisito começava de algum jeito curioso - chamou o avô e lhe disse que o próprio hetman lhe deu ordem para levar uma carta à tzarina. O avô não gostava de demorar para se aprontar: costurou a carta por dentro do chapéu; tirou o cavalo do estábulo; beijou na bochecha a esposa e os seus dois, como ele mesmo chamava, porquinhos, um dos quais era o próprio pai de quem vós fala, e na saída deixou tanta poeira para trás, como se quinze rapazes resolvessem se jogar um em cima do outro no meio da rua ${ }^{553}$.

O estilo peculiar da fala de Fomá Grigórievitch foi anotado já por Siniávski, que disse que os heróis de Dikanka "não sabem falar nem de um modo literário, nem em russo simples, [...] não conseguem juntar duas palavras sem mencionar o diabo, o cunhado e o irmão 554 ," Além do efeito cômico, o objetivo de tais introduções e desvios é ampliar o mundo, aparentemente, pequeno de Dikanka até os tamanhos do universo. Assim como no ornamento gótico, a granja gogoliana cresce em todas as direções: com a introdução das personagens novas, costumes populares e as menções ao diabo.

Os aspectos grotescos do gótico arquitetônico são mais evidentes nas esculturas caricaturescas que evoluíram da ornamentação do século $\mathrm{XV}$, que têm seus paralelos nos caracteres repugnantes e nas cenas horrendas do romance gótico. Basta lembrar as macabras esculturas das gárgulas na Catedral de Notre-Dame de Paris. Os fiéis acreditavam que as gárgulas eram colocadas nas Catedrais Medievais para indicar que o demônio nunca dormia, exigindo a vigilância contínua das pessoas, mesmo nos locais sagrados. Bayer-Berenbaum confirma que "as gárgulas e outras esculturas da catedral gótica, projetadas para afugentar os espíritos malignos, são alusões óbvias a malevolência divina e são grotescas e ameaçadoras, como os vilões na literatura gótica ${ }^{555 \%}$.

\footnotetext{
553 GÓGOL, 2014, p. 97.

554 TERTS, ABRAM, apud SOFRÓNOVA, 2010, p. 17.

${ }^{555}$ BAYER-BERENBAUM, 1982. p. 59.
} 


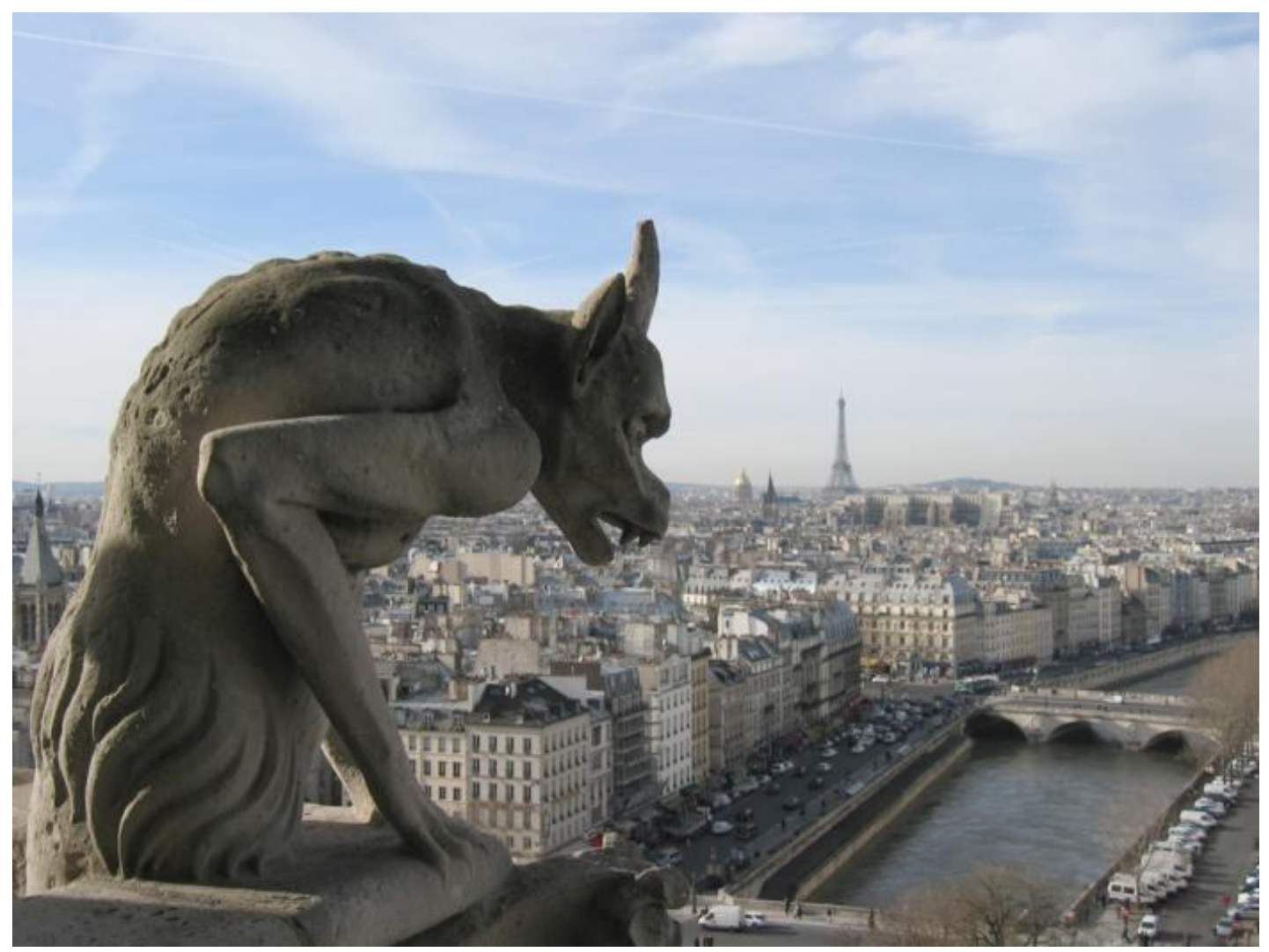

Gárgula na Catedral de Notre-Dame de Paris ${ }^{556}$.

\section{Segundo a estudiosa Renata Philippov,}

'grotesco' era, originariamente, um termo da linguagem da pintura e designava o trabalho de entrelaçamento ornamental (a maior parte das vezes tirado de motivos fabulosos) de um quadro. Seu significado estendeu-se a partir do século XVII e abrangia, já então, o bizarro, a jocosidade burlesca, o elemento distorcido e o estranho em todos os campos ${ }^{557}$.

Em ambos, escultura e literatura, há certa predileção inequívoca pela deformação, pelo exagero dos alguns elementos artísticos. Segundo o estudioso Fred Botting, "gótico significa uma escritura do excesso 558 ". Os vilões góticos, como as gárgulas, têm narizes ou olhos

\footnotetext{
${ }^{556}$ Disponível em: <https://pt.wikipedia.org/wiki/G\%C3\%A1rgula\#/media/File:Notre_dame-paris-view.jpg > Acesso em: 9 ago. 2015.

${ }^{557}$ PHILIPPOV, Renata. Sonhos e fantástico em Edgar Allan Poe e Charles Baudelaire. 1999. Dissertação (mestrado em letras). São Paulo: Universidade de São Paulo, 1999. p. 27.

${ }^{558}$ BOTTING, 1996, pp. 1-2.
} 
grandes, testas alongadas, tumores ou manchas feias, braços ou dentes enormes, cicatrizes ou corcundas; são "ambos fisicamente horrendos e psicologicamente alarmantes ${ }^{559}$ ".

Gógol usa, em abundância, esse recurso artístico. Afirma Arlete Cavaliere que "a sua visão molda a realidade através da desproporção do proporcional ${ }^{560 "}$. Isso se pode também referir às duas coletâneas das novelas ucranianas. Em Noites, seus vilões são horríveis não só na alma, mas também na aparência ${ }^{561}$. Andréi Bélyi dizia que, nos heróis de Gógol, sempre prevalece ou um princípio ferino ou um princípio celeste (especialmente nas personagens femininas): "em frente de nós não são os homens, mas os "ante-homens"; [...] esse mundo, o destino do qual é definido por um carneiro que se aproximara de uma janela, uma gata preta

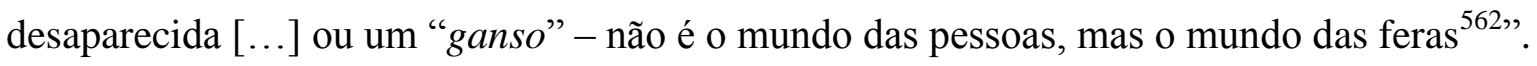

Muitos heróis gogolianos são mais parecidos com os animais ou ainda com os monstros. Por exemplo, o feiticeiro de A Terrível Vingança tem uma habilidade de se disfarçar em cossaco, mas, com o aparecimento da Cruz Santa, seu nariz cresceu e caiu para o lado; de castanhos, os olhos tornaram-se verdes e saltados, os lábios ficaram azuis, o queixo começou a tremer e se afilou em ponta como uma lança, da boca surgiu uma presa, atrás da cabeça se elevou uma corcunda, e o cossaco se transformou num velho ${ }^{563}$.

Dessa descrição do feiticeiro, o simbolista Valéri Briússov tirou uma analogia interessante com o conto de Edgar Allan Poe, Rei Peste (King Pest, 1835), em que os heróis observam, numa festa, pessoas estranhas cujas feições do rosto são exageradas: um nariz, uma orelha, um olho, uma testa etc. Na opinião de Briússov, Gógol usava o mesmo meio artístico não somente na aparência de suas personagens, mas também na composição da obra, nas paisagens, etc.: “Tudo em Gógol cresce por um dos lados - ou para se transformar num algo flagrantemente bonito, ou para se tornar num algo igualmente repugnante. O erro dos críticos foi que eles viram, nesses dois extremos, o realismo, e por muito tempo olharam para a Rússia

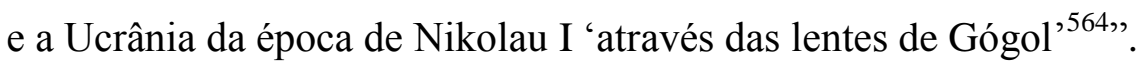

$\mathrm{O}$ vilão, de $A$ noite da véspera do dia de Ivan Kupala, Bassavriuk, parece mais um demônio, não é por acaso que ele é chamado de um diabo de aparência humana ${ }^{565}$. Uma

\footnotetext{
${ }^{559}$ HAGGERTY, 1989, p. 15.

${ }^{560}$ CAVALIERE, 1990, p. 94.

561 Porém é importante notar que, já na coletânea Mirgorod, essa ideia de feiura externa/interna é abordada de um jeito diferente. Assim, a pánnotchka da novela Viy possui uma beleza assustadora, terrível. Vemos que nela o princípio de contraste atingiu seu pique, pois duas qualidades não compatíveis são partes inseparáveis de uma só personagem.

562 BÉLYI, 2009, p. 301.

${ }^{563}$ GÓGOL, 1990, p. 45.

${ }^{564}$ BRIÚSSOV, Valéri. Ispepeliónnyi. K kharakteristike Gógolia. In GONTCHAROV (org.), 2009, p. 458.

${ }^{565}$ GÓGOL, 1976, tomo I, p. 41.
} 
feição que ele tem em excesso é seu olhar que assusta tanto os moradores da granja: Qualquer um ficará com medo quando, às vezes, ele enrugar suas sobrancelhas hirsutas e lançar de soslaio um olhar que fazia qualquer um dar no pé, Deus sabe para onde ${ }^{566}$. Sua aliada, a bruxa, é grotescamente feia: uma velha com o rosto murcho como uma maçã cozida, toda dobrada, o nariz e o queixo como um alicate com o qual se quebram nozes ${ }^{567}$.

A bruxa de Uma noite de maio se destaca por suas garras de ferro, tem a habilidade de se transformar numa gata. O escritor introduz uma imagem perturbadora de uma pata felina que caiu ao chão: Na parede, estava pendurado o sabre de seu pai. Agarrou-o ${ }^{568}$ e o atirou ao chão - uma pata com garras de ferro caiu e a gata, com um ganido, desapareceu num canto escuro $^{569}$ ". Geralmente não associada ao tema de horror na literatura russa do século XIX, a gata, como mencionamos, era considerada um dos animais mágicos, ligados à bruxaria ${ }^{570}$.

O uso do grotesco é ainda mais visível nas personagens secundárias, como os diabos e as bruxas de A Carta Perdida, com seus focinhos de porcos, cachorros, bodes, grous e cavalos. Afirma o pesquisador Serguéi Chambinago que a descrição de Sabbat das bruxas, nessa obra, nos lembra das esculturas na catedral gótica ${ }^{571}$ : Carrancas, como eles dizem, a perder de vista. Um sem-número de bruxas, como, às vezes, a neve que cai no Natal: enfeitadas e pintadas como coquetes numa feira. E todos que haviam ali, como os ébrios, estavam envolvidos em algum baile infernal ${ }^{572}$.

Segundo Chambinago, os dois artistas - Nikolai Gógol e o pintor Francisco Goia foram os primeiros a compreender que o terrível interior da personagem deve coincidir com o horrível exterior. Significava que "é insuficiente ver a diabrura apenas como um fruto da imaginação, ela já é além da imaginação, é uma realidade terrível ${ }^{573}$. As personagens grotescas de Gógol, apresentadas em todas as suas deformações e exageros, beirando caricaturas, desenham a imagem de um mundo deformado no limiar do fantástico e do monstruoso.

\footnotetext{
${ }^{566}$ Idem, Ibidem, p. 42.

${ }^{567}$ Idem, Ibidem, p. 47.

568 (A heroína).

${ }^{569}$ GÓGOL, op. cit., p. 58.

570 Para ver mais sobre o significado simbólico dos animais, recomendamos ler AFANÁSS'EV, A.K. Poètítcheskie vozzréniia slavián na prirodu. Em três tomos. Tomo III. Moskvá: Sovreménnyi pisátel', 1995. p. 533.

${ }^{571}$ CHAMBINAGO, S.K. Gógol' $i$ Goia. In GONTCHAROV (org.), 2009, p. 496.

${ }^{572}$ GÓGOL, 2014, p. 87.

${ }^{573}$ CHAMBINAGO, op. cit., p. 487.
} 
O contraste c $^{574}$ é um meio artístico comum nas catedrais góticas. Suas vidraças transparentes, cintilantes e coloridas estão opostas às paredes de pedra - sólida e opaca. Essa contraposição intencional é visível no jogo das cores dos vitrais: o vermelho e o preto para mostrar as cenas do inferno e o branco e azul-celeste - para o paraíso.

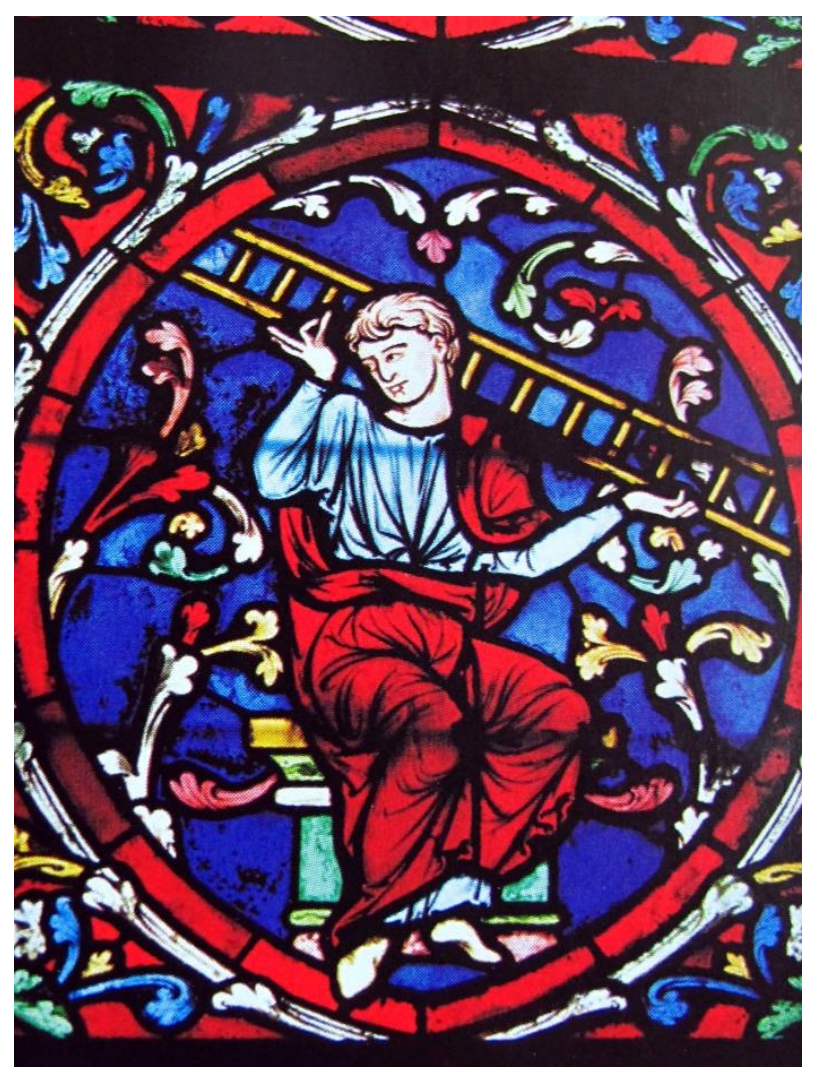

Fragmento de vitral na Catedral de Notre-Dame de Paris ${ }^{575}$. O santo é cercado pela cor azul e azul-celeste.

O romance gótico adotou bem o esquema de oposições e até aumentou sua quantidade: começo/fim, alto/baixo, luz/sombra, interno/externo, vida/morte, herói/vilão, angélico/diabólico, beleza/feiura, etc. Esses contrastes, segundo Simpson, formavam, na obra gótica, um universo desordenado, mas bem delineado no qual o bem e o mal se misturavam em uniões, às vezes, indissolúveis ${ }^{576}$.

O princípio de contraste organiza toda a estrutura do texto gótico, contrapondo uma palavra e uma imagem, um enredo e uma ideia geral da obra, o sentido interno e o sentido externo. O contraste também forma a base da estética do jovem Gógol. Nas suas novelas

\footnotetext{
${ }^{574}$ Nessa parte do capítulo, não analisamos A Carta Perdida, porque o escritor praticamente não usa este meio artístico na novela em questão.

${ }^{575}$ PANTILÉEVA, A. I. (org.) Sámye znamenitye chedévry gótiki. Moskvá: Belyi Górod, 2014. p. 83.

${ }^{576}$ SIMPSON, 1986, p. 11.
} 
ucranianas, se pode observar o contraste no nível de composição, no nível das personagens, no nível dos objetos e no nível da paisagem.

Segundo a estudiosa Ekaterina Dmítrieva, o contraste já é percebido no nível da

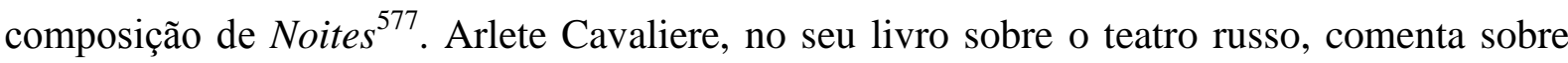
este fenômeno da obra gogoliana em geral: "O princípio cômico estruturador sempre se transforma num esgar trágico, e a visão carnavalesca que preside os seus textos se faz sempre enfraquecida em seu desfecho para dar lugar a um tom lúgubre e espantoso, como se universo do texto se tornasse, numa fração de segundos, hostil e alheio ${ }^{578,}$.

Na coletânea, novelas engraçadas são seguidas por outras tristes e vice-versa. Assim, depois da alegre e animada A Feira de Sorótchintsy, justapõe-se a sombria $A$ noite da véspera do dia de Ivan Kupala, seguida por Uma noite de maio, uma novela triste, mas, ao mesmo tempo, cômica. O final do primeiro tomo é A Carta Perdida, com seu tom alegre, final feliz. No segundo tomo, após uma novela engraçada, A noite de Natal, A Terrível Vingança apresenta a história do perecimento da família do cossaco Danilo, seguida por uma neutra Ivan Fiódorovitch Chponka e sua tia e completada pela divertida e mágica Um lugar encantado.

Mesmo dentro de cada novela, o princípio de contraste domina sua estrutura e composição. Assim, em A Terrivel Vingança, após as mortes dos heróis e o julgamento final do feiticeiro, o bandurrista canta os poemas cômicos sobre Khomá e Ierióma que encerram a ação trágica.

Em A noite da véspera do dia de Ivan Kupala, os acontecimentos horríveis no bosque, onde Petró mata uma criança, são seguidos por uma descrição alegre do casamento:

O próprio Korj não aguentou ver os jovens e decidiu recordar os velhos tempos. Com a bandurra nas mãos, fumando seu cachimbo e, ao mesmo tempo, cantarolando, balançando um cálice sobre a cabeça, o velhão pôs-se a dançar a prisiádka com um grito alto de farrista. O que as pessoas não inventam quando estão meio altas! Quando começam, às vezes, a pôr máscaras - meu Deus, nem parecem pessoas! ${ }^{579}$.

O efeito de contraste é ainda mais forte no final da novela, quando toda a felicidade de Pidorka e Petró é destruída num só momento - Petró desaparece no fogo infernal, e Pidorka vai ao monastério para salvar sua alma.

\footnotetext{
577 DMÍTRIEVA, 2011, p. 58.

${ }^{578}$ CAVALIERE, 2009, p. 26.

${ }^{579}$ GÓGOL, 1976, tomo I. p. 49.
} 
Em Uma noite de maio, a triste história da pánnotchka está em contraste com o seu "duplo" cômico - a história da sogra do destilador: pánnotchka persegue sua madrasta para se vingar, e, ao mesmo tempo, o misterioso hóspede morto persegue a sogra para se vingar, guardando uma galuchka entre seus dentes. O contraste, nessa novela, é usado para fortificar, ao mesmo tempo, o efeito trágico da história da pánnotchka, e o efeito cômico da história da sogra.

Em A Carta Perdida, a volta bem sucedida do cossaco para casa parece perturbada pela imagem de sua esposa, que está sob o efeito por algum feitiço desconhecido: viu as crianças, assustadas, vindo de costas em sua direção e gesticulando, que disseram: "Olha, olha, a mãe está saltando feito uma doida!'. E, realmente, a baba estava sentada, dormindo em frente ao pente, segurava na mão o fuso e, sonolenta, saltava no banco ${ }^{580}$.

Provavelmente, o contraste mais significativo é aquele entre os heróis (ou as heroínas) e os vilões (ou as vilãs) da coletânea ${ }^{581}$. Segundo Vatsuro, com o desenvolvimento do romance gótico, a importância do vilão crescia, "outro inevitável atributo do romance era seu antípoda ou vítima - o herói ou a heroína do tipo ideal, contrapostos a ele ${ }^{582 \%}$. BayerBerenbaum expressa a ideia de que "o romance gótico não apresenta os tons tranquilos de cinza: as personagens são, principalmente, dotadas ou com as qualidades sombrias, diabólicas do vilão ou com as virtudes puras, angelicais ${ }^{583}$ ".

Em A Terrivel Vingança, o contraste é visível entre o feiticeiro e a sua filha, por quem ele está apaixonado, junto a seu aliado e marido Danilo. Para provar isso, vale lembrar as tintas que Gógol usou nas descrições de personagens. O rico uso da cor, em Noites, já foi observado por Bélyi: nos seus cálculos estatísticos, as obras da primeira fase de Gógol ${ }^{584}$ são duas vezes mais "coloridas" que o primeiro tomo do romance Almas Mortas; a cor mais aplicada é o vermelho. Segundo Bélyi, "na primeira fase de Gógol, uma tinta é uma tonalidade; um desenho é uma melodia ${ }^{585}$ ". Também Zolotússki salienta que "o mundo de Gógol, em Noites, é pitoresco, multicor. Ele reverbera em centenas de cores - são as cores da estepe ucraniana durante o dia ou na hora do pôr de sol, do céu ucraniano, de Dnepr, da

\footnotetext{
${ }^{580}$ GÓGOL, 2014, p. 104.

${ }^{581}$ No item anterior, analisamos apenas o comportamento e o caráter dos heróis que entraram em oposição com o vilão. Nesse ítem, falamos dos procedimentos estilísticos que destacam a sua diferença.

${ }^{582}$ VATSURO, 2002, p. 61.

${ }^{583}$ BAYER-BERENBAUM, 1982, p. 19.

${ }^{584}$ São os dois tomos de Noites em uma Granja e o primeiro tomo de Mírgorod.

585 BÉLYI, 1934, p. 125.
} 
alegria festiva numa feira, as cores das roupas dos rapazes e das meninas, dos enfeites do casamento rural e da casa camponesa ${ }^{586,}$.

Provavelmente o uso de cor é um dos efeitos aplicados com mais frequência por Gógol, na sua obra, para indicar contraste. A contraposição de cor e de som são características também para as obras góticas ${ }^{587}$. Afirma a pesquisadora Tatiana Allénova que "no âmbito do gênero das obras pesquisadas, a cor se torna um dos meios principais da criação [...] do terrível: sendo, por um lado, um símbolo, e por outro, um meio de ajudar ao autor a desenhar as diferentes manifestações do maravilhoso e terrível, que tiram os acontecimentos das fronteiras da realidade léxico-semântica ${ }^{588 \%}$.

Para descrever o valente cossaco e sua esposa, em A Terrível Vingança, Gógol aplica as cores do céu: azul, azul-claro, branco, rosa, dourado. Assim, quando ele faz o retrato de Danilo, ele menciona que reflete-se nos olhos o cinto de ouro no jupan azul ${ }^{589}$. As cores, na descrição de Katerina, são parecidas com as do mundo celestial: Maravilhavam-se os convidados com o rosto branco de pani Katerina, suas sobrancelhas negras como veludo alemão, e a elegante saia de lã azul e as botas de tacões de prata ${ }^{590}$. Parece que a heroína é feita de ar: a cabeça transparente: brilham suaves seus olhos azul-pálidos; os cabelos ondulam e espalham-se sobre os ombros como uma névoa cinza-claro; os lábios avermelham-se como se através do céu matinal branco, translúcido se derramasse imperceptivel a luz rubra da aurora ${ }^{591}$.

Bélyi percebeu o caráter artificial, escultural das heroínas gogolianas e assim comentou sobre o assunto: "Quando ele descreve uma mulher, ou é um sonho, ou uma estátua fria com os seios 'opacos como porcelana não coberta por esmalte', ou uma baba luxuriosa, que, à noite, anda pé ante pé ao seminarista. Será que não existe uma mulher, e há somente uma baba ou uma sereia com os seios de porcelana, esculpida das nuvens? ${ }^{592, "}$

Se aplicarmos os termos das artes plásticas, Katerina, de $A$ Terrível Vingança, seria a cúpula da catedral e o feiticeiro - o seu oposto, o chão no qual pisam os pecadores. $\mathrm{O}$ azulceleste, que simboliza a pureza e a inocência, acompanha tudo que cerca a pani Katerina. Quando sua alma aparece diante do feiticeiro, de repente, por todo o quarto se espalhou suave

\footnotetext{
${ }^{586}$ ZOLOTÚSSKI, 2005, p. 124.

${ }^{587}$ VATSURO, 2002, p. 233.

588 ALLÉNOVA, Tatiana. Kategória irreálnovo ujásnovo $i$ spóssoby eió vyrajéniia v khudójestvennom prostránstve N.V. Gógolia (na materiale iazyká povestéi "Vetcherá na khútore bliz Dikanki" $i$ "Mírgorod"). Tese (Doutorado em filologia). Moskvá: Universidade estatal de Moscou de pedagogia (MPGU), 2000. p. 52.

${ }^{589}$ GÓGOL, 1990, p. 68.

${ }^{590}$ Idem, Ibidem, p. 44.

${ }^{591}$ Idem, Ibidem, p. 59, grifo nosso.

${ }^{592}$ BÉLYI, 2009, p. 302.
} 
uma luz de um azul translúcido. Só que esta luz não se misturou às ondas anteriores pálidadouradas que se irisavam e, mergulhando como num mar azul, se esticavam em camadas como mármore ${ }^{593}$. Pode-se observar, nesse trecho, que Gógol, novamente, recorre às comparações arquitetônicas. Uma combinação do pálido-dourado e do azul translúcido, assim como uma menção de mármore, evoca no leitor associações com a decoração interior da catedral gótica.

Quando o narrador trata do vilão, ele, ao contrário, usa em abundância as cores "infernais": o vermelho, o rubro, o escarlate e o negro. No momento em que Danilo tenta espiar para saber as intenções do pai de Katerina, ele vê alguém vestido com um jupan vermelho, com duas pistolas e com um sabre ao lado ${ }^{594}$. Na cena em que o feiticeiro mata o cossaco, Apenas o fiel Stetska viu quando passou a roupa vermelha e o gorro estranho ${ }^{595}$. Parece que a cor vermelha intensifica-se com o desenrolar dos acontecimentos: e era terrivel olhar então seu rosto. Parecia de sangue, e somente se destacavam nele as rugas negras e profundas, e os olhos como fogo ${ }^{596}$.

A cor negra, também associada em Gógol aos terrores da noite, acompanha não só a aparência, mas toda a característica do feiticeiro; aparecem epítetos como alma negra, pensamentos negros como a noite. Na novela, o jogo de cores é destinado para destacar a oposição de dois lados que estão em conflito.

Já em A noite da véspera do dia de Ivan Kupala, observamos uma contraposição entre o casal dos namorados e o vilão Bassavriuk. O enredo dessa novela é uma história sobre a queda moral: o protagonista não consegue resistir à tentação. Por isso, desde o início, ele é descrito não com a cor branca, mas com cinza: Petró tinha apenas um camisolão cinza com mais buracos do que moedas de ouro nos bolsos de algum judeu ${ }^{597}$. Allénova indica que "o significado semântico do adjetivo cinza é a mesma do adjetivo preto, que simboliza a força impura ${ }^{598 \%}$. Isso significa que o herói é mais próximo dos representantes do mundo mágico que os outros. Sua namorada é descrita com os tons de rosa que revelam sua juventude e ingenuidade. Suas bochechas são rosadas e ardentes como uma papoula cor-de-rosa mais

\footnotetext{
${ }^{593}$ GÓGOL, 1990, p. 58.

${ }^{594}$ Idem, Ibidem, p. 57.

595 GÓGOL, 1976, tomo I, p. 68.

${ }^{596}$ Idem, Ibidem, p. 71.

${ }^{597}$ Idem, Ibidem, p. 43.

${ }^{598}$ ALLÉNOVA, 2000, p. 61.
} 
suave $^{599}$, seus lábios também são rosados. Na descrição de Bassavriuk, se destacam o preto e o negro.

Em Uma noite de maio, o contraste é entre a pánnotchka e a sua madrasta. Na descrição da primeira, prevalece o branco e as cores parecidas como prata. Branco é a cor predominante não somente na pánnotchka, mas também na namorada do protagonista Levkó. Assim, Ganna tem rostinho branco, perninhas brancas, mãozinha branca ${ }^{600}$ e a roupa branca: Entre as árvores, viu-se uma camisa branca ${ }^{601}$. Pánnotchka também é branca como a neve, branca como o teu rosto ${ }^{602}$; primeiro um cotovelo branco se debruçou na janela, depois apareceu uma cabeça pequena e gentil, com uns olhos cintilantes que irradiavam luz através das ondas dos cabelos castanho-escuros e se encostou no cotovelo ${ }^{603}$ e ainda Toda ela era branca como papel, como o brilho da lua crescente; mas como era admirável, como era bonita! $!^{604}$.

As amigas da pánnotchka são também caracterizadas pelas cores prateadas. A descrição das moças afogadas possui duas conotações importantes: a primeira, sua aliança com a heroína, e a segunda, um indicador ao mundo "alheio". Segundo Vladímir Propp, nos conceitos folclóricos, "o branco [...] é a cor dos seres do outro mundo [...]. O branco é a cor dos seres que perderam a corporalidade, por isso que os fantasmas são brancos ${ }^{605}$. Lê-se em Uma noite de maio:

[...] na neblina fina e prateada passavam rapidamente, leves como sombras, moças em camisas brancas, como em um prado coberto de lírios do vale; seus colares de ouro, seus enfeites e ducados tremeluziam em seus pescoços, mas estavam pálidas; era como se seus corpos fossem esculpidos em nuvens transparentes e pareciam reluzir de um lado ao outro sob a luz da lua crescente prateada ${ }^{606}$.

A antagonista - a bruxa- é associada à cor preta. Todas as três imagens da bruxa (a madrasta, a gata e uma das moças afogadas na turma da pánnotchka) têm uma feição em comum - uma impressão de escuridão. A bruxa-gata é descrita especificamente com a cor preta: De repente, vê uma horrivel gata preta se aproximando dela de mansinho; sua pele

\footnotetext{
${ }^{599}$ GÓGOL, 1976, tomo I, p. 43.

${ }^{600}$ Idem, Ibidem, p. 55.

${ }^{601}$ Idem, Ibidem, p. 63.

${ }^{602}$ Idem, Ibidem, p. 57.

${ }^{603}$ Idem, Ibidem, p. 75.

${ }^{604}$ Idem, Ibidem.

${ }^{605}$ PROPP, 1997. p. 207.

${ }^{606}$ GÓGOL, op. cit., p. 76.
} 
arde e as garras de ferro arranham o chão ${ }^{607}$. Na descrição da bruxa-afogada, são usados os mesmos detalhes que foram acentuados nas imagens de bruxa-madrasta e bruxa-gata: seu corpo reluzia de um jeito diferente das outras: dentro dele se via algo negro ${ }^{608}$. Não é uma coincidência que Levkó identifique a bruxa entre as moças afogadas durante o jogo de corvo. Segundo a estudiosa Poliakova, "a imagem do corvo sempre encarnava um princípio ameaçador, perigoso, ligado à esfera do "alheio", não por acaso o corvo é considerado um atributo das bruxas e dos feiticeiros ${ }^{609}$ ".

O contraste funciona não somente nas personagens, mas também nos objetos que os cercam. O estudioso Gurévitch traz observações interessantes em relação às obras arquitetônicas na prosa de Gógol. Conforme sua pesquisa, "a casa de cada um dos heróis é uma personificação evidente do seu gosto, dos seus costumes, das ideias de si e do universo. Este mundo artificialmente criado é sempre organizado de um jeito parecido com seu dono; nele, como num espelho, é refletido o caráter do seu dono ${ }^{610,}$.

Pode-se observar esse contraste dos objetos em A Terrível Vingança. Há uma analogia entre o feiticeiro e seu castelo, o lugar dos crimes e pecados terríveis. Assim como na característica do vilão, na descrição do lugar que lhe pertence, prevalecem os tons avermelhados: um pouco além sobre o Dnepr arde o seu castelo diabólico ${ }^{611}$.

$\mathrm{Na}$ opinião de Allénova, em Gógol, “a semântica da cor vermelha é, em primeiro lugar, 'sangue', por isso que tal característica de cor é uma parte integrante da descrição de uma força impura, das suas ações, de tudo que tem relação a ela. Tudo horrível em Gógol é vermelho $^{612 \%}$. O vermelho é o símbolo do mal que supera todos outros símbolos no contexto das novelas ucranianas. As letras no livro do monge que encontra com o feiticeiro reagem com a cor vermelha quando "percebem" a presença do vilão: Olha: as letras santas do livro se encheram de sangue. Jamais existiu no mundo um pecador semelhante! ${ }^{613}$

Diferentemente do castelo, a casa de Danilo e de Katerina é descrita com os tons neutros, cinza e marrom. Gógol não necessariamente usa os adjetivos de cor, mas coloca os objetos para os quais essas cores são características:

\footnotetext{
${ }^{607}$ GÓGOL, 1976, tomo I, p. 58.

${ }^{608}$ Idem, Ibidem, p. 77.

${ }^{609}$ POLIAKOVA, 2008, p. 94.

${ }^{610}$ GURÉVITCH, Pável. Rol' óbrazov plastitcheskikh iskusstv v khudójestvennom mire Gógolia (na materiale khudójestvennoi prozy). In MANN (org.), 2003, p. 91.

${ }^{611}$ GÓGOL, 1990, p. 62.

${ }^{612}$ ALLÉNOVA, 2000, p. 56.

${ }^{613}$ GÓGOL, op. cit., p. 79.
} 
Sua morada não é alta: na aparência é uma khata como a dos cossacos comuns. Há apenas uma sala, mas é suficiente para alojar a ele, à sua mulher, e também à velha criada e ainda aos dez rapazes mais valentes. Em volta das paredes, no alto, há prateleiras de carvalho. Nelas estão amontoadas tigelas e potes para o repasto. Vêem-se também taças de prata e copinhos folhados a ouro, alguns doados, outros pilhados na guerra. Mais abaixo estão pendurados mosquetes, preciosos sabres, arcabuzes e lanças [...] Embaixo, junto às paredes, há barcos de carvalho aplainado. Ao lado, diante da liejanka, preso por cordas que passam por uma argola rosqueada no teto, está o berço. Por toda a sala, o chão é liso e recoberto por uma massa de argila bem batida ${ }^{614}$.

Nessa imagem, podem-se perceber dois aspectos contrastantes à imagem do castelo. Em primeiro lugar, a casa de Danilo gera uma impressão de força e solidez. O castelo, ao contrário, está num estado de velhice e destruição lenta. Vários detalhes indicam que ele é impróprio para moradia: Sob o teto vão e vêm morcegos, e sua sombra projeta-se nos muros, pelas portas, pelo estrado ${ }^{615}$; ou ainda: Pelos degraus de pedra, ele desceu por entre cepos queimados; lá embaixo, na terra profunda, está escavado seu abrigo ${ }^{616}$.

Em segundo lugar, a casa de Danilo é uma moradia coletiva, dividida por um grande grupo de pessoas, não somente uma família, mas por um clã, enquanto o feiticeiro mora completamente sozinho. Esse contraste torna mais evidente o tema do conflito entre o indivíduo e o clã. Zolotússki faz observações interessantes em relação às casas das personagens:

A casa construída com o amor, em acordo, é duradoura. Baseada na desgraça, a casa se destrói. Assim se destrói e queima a casa de Petró e Pidorka, em A noite da véspera do dia de Ivan Kupala, desaparece no fogo a casa do feiticeiro, está abandonada a casa do sótnik em Uma noite de maio. Cada um dos habitantes dessas casas era um renegado em algo, um criminoso $^{617}$.

Em A noite da véspera do dia de Ivan Kupala, há dois objetos que entram no contraste. São o lençol branco que está cobrindo Ivás e a vermelha flor de samambaia. O lençol aparece na obra duas vezes. A primeira vez, na cena do assassinato: a bruxa [...] conduziu até ele uma criança de uns seis anos coberta por um lençol branco, fazendo-lhe

\footnotetext{
614 GÓGOL, 1990, p. 50.

${ }^{615}$ Idem, Ibidem, p. 58.

${ }^{616}$ Idem, Ibidem, p. 71.

${ }^{617}$ ZOLOTÚSSKI, 2005, p. 126.
} 
entender, por gestos, que ele precisava cortar a sua cabeça ${ }^{618}$. A segunda vez, quando o fantasma da criança surge diante dos heróis: A velha desapareceu e uma criança de uns sete anos, com uma camiseta branca, com a cabeça coberta, surgiu no meio da casa... O lençol caiu $^{619}$.

Conforme Allénova, "o adjetivo branco recebe uma carga semântica peculiar, em alguns casos, se torna num símbolo de pureza e inocência ${ }^{620 "}$. O vermelho simboliza pecado. Na cena do assassinato de Ivás, em primeiro lugar, aparece o objeto mágico - a flor de samambaia. Na terminologia do conto maravilhoso, o objeto mágico é uma coisa necessária para o herói vencer os obstáculos: "O conto atinge seu apogeu ao colocar nas mãos do herói o recurso mágico. [...] Agora ele caminha firme para o seu objetivo e sabe que o atingirá ${ }^{621 "}$. Mas, em Gógol, o pensamento folclórico do conto é complicado pela percepção religiosa. $\mathrm{Na}$ novela, a flor não possui poder nenhum se o herói não matar uma pessoa inocente, e, por isso, ela arde com cor vermelha:

De repente, vê um pequeno botão avermelhando-se, era como se estivesse vivo, mexendo-se. É maravilhoso de verdade! Está se mexendo e ficando maior, maior e avermelhando como uma brasa quente. A estrelinha se inflamou e algo começou a crepitar fracamente e uma flor se abriu diante de seus olhos como uma chama, iluminando as outras ao seu redor ${ }^{622}$.

O vermelho também permanece forte na cena do reaparecimento do fantasma de Ivás - o fantasma ficou ensanguentado dos pés à cabeça e iluminou a casa inteira com uma luz vermelha ${ }^{623}$. Aqui o vermelho indica o crime cometido, revela o mistério do comportamento de Petró.

Em Uma noite de maio, existe o contraste entre as duas imagens da mesma casa de sótnik. Após os acontecimentos tristes, associados aos malfeitos da bruxa, a casa parece um lugar triste, sem vida: se encontrava a casa antiga com os contraventos fechados; o musgo e as ervas daninhas indicavam que os moradores a haviam abandonado há muito tempo ${ }^{624}$. Porém, o prédio se ilumina com o aparecimento da pánnotchka, que o enche com o

\footnotetext{
${ }^{618}$ GÓGOL, 1976, tomo I, p. 47.

${ }^{619}$ Idem, Ibidem, p. 51.

${ }^{620}$ ALLÉNOVA, 2000, p. 65.

${ }^{621}$ PROPP, 1997, p. 195.

${ }^{622}$ GÓGOL, op. cit., p. 46.

${ }^{623}$ Idem, Ibidem, p. 51.

${ }^{624}$ Idem, Ibidem, p. 78.
} 
irradiamento da vida: No lugar dos contraventos soturnos, as janelas de vidro e as portas resplandeciam alegremente. Através das vidraças limpas, cintilava algo dourado ${ }^{625}$.

O contraste nas novelas se espalha não apenas nos objetos, mas também na paisagem. Segundo Bayer-Berenbaum, a paisagem gótica "se lança de um extremo para outro; da altura de uma aérea torre sineira às profundezas da masmorra ${ }^{626 "}$. Esses contrastes estão inclusos no estilo gótico, porque eles ampliam a realidade: entre os grandes extremos está situada a maior largura. A presença constante das oposições polares ajuda aos leitores a não ver uma só dimensão da vida como um tudo, mas se adaptar aos pontos de vista diferentes.

Em A Terrível Vingança, o rio Dnepr, que, nessa novela, simboliza a livre vida dos cossacos e suas façanhas nos tempos antigos, tem muito em comum com o pan Danilo. No conflito entre o feiticeiro e Danilo, o rio, por assim dizer, "toma o lado" do segundo. Dnepr parece uma pessoa e também é "vestido" de azul:

Azul, azul ele corre transbordando fluidamente durante a noite e durante o dia, e pode ser visto de tão longe quando é possivel ao olho humano. Acariciando-a, aconchega-se mais para junto da margem devido ao frio da noite, e desata sobre si uma corrente de prata; esta resplandece como a raia de um sabre de Damasco; e ele, azul, de novo adormece ${ }^{627}$.

Mas as ações ímpias do feiticeiro "perturbam" o rio, e, por isso, a imagem está se transformando, aparece, na sua descrição, a cor vermelha: ondas vermelhas como sangue fustigam e se avolumam ao redor dos velhos muros. [...] Ele está lá por uma traição secreta, por sua confabulação com inimigos da terra russa ortodoxa, e por vender o povo ucraniano $^{628}$.

Em A noite da véspera do dia de Ivan Kupala, é possível também perceber o contraste nas descrições da natureza. A felicidade e a inocência são descritas por meio das imagens da madrugada, do nascimento da luz, do sol, que estão aparecendo no retrato de Pidorka: as bochechas rechonchudas da cossaca eram rosadas e ardentes como uma papoula cor-de-rosa mais suave, quando, depois de se lavar com o orvalho de Deus, ela brilha, endireita as folhinhas e se apruma perante o sol $^{629}$.

Ao contrário, a aproximação dos eventos escuros, misteriosos e sombrios é assinalada pela chegada da noite, na véspera do dia de Ivan Kupala. Este dia, que, de acordo com o velho

\footnotetext{
${ }^{625}$ GÓGOL, 1976, tomo I, p. 75.

${ }^{626}$ BAYER-BERENBAUM, 1982, p. 22.

${ }^{627}$ GÓGOL, 1990, p. 70.

${ }^{628}$ Idem, Ibidem, pp. 61-62.

${ }^{629}$ GÓGOL, 1976, tomo I, p. 43.
} 
calendário eslavo, era comemorado 24 de junho, corresponde ao tempo de solstício de verão; nas crenças populares, o dia em que as forças demoníacas eram mais potentes. Por isso, a paisagem, na obra, reflete a aproximação de algo sinistro pelo aparecimento das cores pretas e vermelhas: Finalmente o sol desaparece. Apenas o céu avermelha-se de um lado. E já está empalidecendo. No campo, começa a ficar mais frio. Está escurecendo, escurecendo e escureceu ${ }^{630}$. A impressão de escuridão é reforçada com as imagens do Medvéji Ovrag: Não se enxerga nada. As ervas daninhas negrejavam ao redor e sufocavam tudo com sua densidade ${ }^{631}$.

Quando Petró mata uma criança, toda a paisagem reage, respondendo ao herói com uma paleta de cores avermelhadas. Isso simboliza a queda final do protagonista e a assinatura de um pacto com o diabo: Tudo à sua frente ficou coberto de vermelho. As árvores, ensanguentadas, pareciam arder e gemer. O céu, incandescido, tremia... Manchas de fogo, feito relampagos, lhe apareciam aos olhos ${ }^{632}$.

Em Uma noite de maio, as paisagens da novela também entram em contraste. Quando Levkó conta a sua namorada a história da pánnotchka, a paisagem é sombria:

[...] o lago sombrio, cercado por uma floresta escura de bordo e pelos salgueiros chorosos, que afogaram nele seus galhos lamentosos. Como um fraco ancião, ele agarra com seus abraços frios o céu longínquo, escuro, cobrindo de beijos gélidos as estrelas ardentes que, opacas, deslizam no meio do morno ar noturno ${ }^{633}$.

Com o aparecimento da moça afogada em frente do herói, são introduzidas na descrição da natureza, tais cores como prata: Olhou ao redor: a noite diante dele parecia ainda mais brilhante. Uma luz estranha, deleitosa se misturou com o resplendor da lua crescente. Nunca antes lhe ocorrera ver algo assim. Uma neblina prateada caiu sobre os arredores $^{634}$. O aparecimento de uma névoa prateada, no segundo trecho, significa o deslocamento do herói do mundo cotidiano ao mundo alheio.

Essas descrições contrastantes possuem duas funções principais na novela. A primeira é criar, nos leitores, um ambiente emocional apropriado. Segundo o estudioso Spacks, o simbolismo filosófico da paisagem melancólica no gótico "conduzia o leitor ao pensamento sobre o caráter frágil e transitório da existência terrena, e sobre consolação no reino de

\footnotetext{
${ }^{630}$ GÓGOL, 1976, tomo I, p. 45.

${ }^{631}$ Idem, Ibidem, p. 46.

${ }^{632}$ Idem, Ibidem, p. 48.

${ }^{633}$ Idem, Ibidem, p. 57.

${ }^{634}$ Idem, Ibidem, p. 75.
} 
Deus ${ }^{635 \%}$. A segunda função é delinear a diferença entre dois mundos - real e fantástico -, e preparar o leitor à transição do protagonista de um mundo para outro.

Chegamos à conclusão de que o estilo gótico não era apenas um momento na história da arquitetura, mas uma concepção do diferente mundo - sombrio e misterioso -, que depois passou a ser uma parte importante da poética do "romance de terror", e influenciou, especialmente, os temas literários e os elementos de linguagem das obras, como epítetos e metáforas. Gógol, com seu gosto pelas imagens misteriosas da catedral gótica, em certa medida, encarnou o princípio arquitetônico em suas novelas.

${ }^{635}$ SPACKS, P.M. Horror-Personification in late 18 Century Poetry // Studies in Philology, 1962, Vol. 59, №3,pp. 566-568 apud Vatsuro, 2002, p.88. 


\section{Conclusão}

Essa coletânea consiste das peças escritas por mim em tempos diferentes, em épocas diferentes da minha vida. Não as escrevi ao pedido. Elas se expressavam da minha alma, e eu escolhia como um objeto somente aquilo que me impressionava fortemente ${ }^{636}$.

(Gógol, Arabescos, 1834-1835)

$\mathrm{Na}$ literatura clássica russa, nenhum escritor conseguiu expressar o horror existencial tão profundo como Nikolai Gógol. Os princípios do "romance de terror" eram próximos do escritor por causa da sua ligação com o romantismo alemão, e também por causa das suas peculiaridades psicológicas. O catastrofismo da consciência do escritor já foi percebido pelos pesquisadores $^{637}$. Nesse sentido, parece de crucial importância o seu interesse pelas várias manifestações do gótico: pela estética da arte gótica, especialmente, na arquitetura e na pintura, e pela história da Idade Média, que se tornou uma base para o renascimento gótico na Europa. Não existem indicações documentárias do conhecimento dos romances góticos por Gógol, mas uma orientação - consciente ou inconsciente -, nesse gênero, revela-se já nas suas primeiras obras, publicadas nos anos 30 do século XIX, como demonstram as novelas analisadas nesta dissertação.

No entanto a análise da influência do próprio gênero do romance gótico inglês na obra gogoliana, em geral, está ainda no nível da formulação e da elaboração do problema. A maioria dos artigos dedicados à questão do "gótico e Gógol" trata de uma comparação tipológica dos textos do escritor russo com os romances de Walpole, Maturin, Lewis, e o romance gótico de Hoffmann, O Elixir do Diabo. Os pesquisadores, nesses trabalhos, falam, cautelosamente, de elementos isolados, e, muitas vezes, não fundamentais da poética do gótico nas obras do autor.

Tentando preencher as lacunas sobre o tema de nosso interesse, nesta dissertação não nos baseamos na comparação de Gógol com os outros autores góticos, mas nos esforçamos para traçar um perfil detalhado dos procedimentos góticos em si, transpondo-os para o contexto das novelas gogolianas. Na pesquisa, nos limitamos às peculiaridades significativas

\footnotetext{
${ }^{636}$ GÓGOL, 1976, tomo VI, p. 22.

${ }^{637}$ VIROLÁINEN, 2003, p. 9.
} 
do gótico, como as questões do espaço cênico, a técnica narrativa, o sistema dos personagens e a correlação entre o gótico literário e os procedimentos arquitetônicos.

No caso do espaço gótico, foram abordados aspectos importantes como a imagem do castelo, a divisão do espaço físico em um mundo real, um mundo fantástico e um espaçofronteira. Caracterizamos os momentos definitivos do espaço gótico por meio do sistema das oposições como estática/dinâmica, vivo/morto e silêncio/som. Foi crucial para a nossa pesquisa a análise do conceito da ativação de fronteira em Gógol, e também os temas relacionados a ela, como os temas do labirinto, da surdez e do desentendimento.

No item sobre a técnica narrativa, destacamos as funções góticas principais das narrativas inseridas nas novelas, dentre as quais se destacam a criação de uma distância temporal entre o leitor e os heróis, o processo de surgimento de uma lenda, a introdução dos elementos fantásticos no enredo, e a objetivação do ponto de vista do escritor. Foi mostrado como o enredo e o desenlace da novela dependem das imagens do editor e dos narradores.

No sistema dos personagens, explicamos o caráter desigual da oposição entre o herói e o vilão. Foram apresentados alguns aspectos dos personagens principais e a sua relação com os temas góticos como vingança, maldição familiar e mistério.

Finalmente, no item sobre a influência da arquitetura na poética do gótico, mostramos como as metáforas relacionadas à arquitetura e arte góticas e os temas inspirados na arquitetura revelam-se nos textos literários gogolianos. Entre os procedimentos marcantes estão o efeito da transformação espiritual, a complexidade das descrições da natureza, inspiradas nos ornamentos góticos, os procedimentos do contraste e do grotesco.

Ao que parece, conseguimos indicar a presença significativa do próprio espírito do gótico em Noites em uma granja perto de Dikanka. Para isso, foram analisadas as novelas que, em nossa ótica, levam uma "carga" maior do gótico: A Terrível Vingança, A noite da véspera de Ivan Kupala, Uma noite de maio, ou uma moça afogada, A Carta Perdida. Posteriormente, faz-se possível continuar a pesquisa dos elementos góticos nas outras novelas da coletânea. No contexto do espaço gótico, parece interessante a futura tradução e análise da novela Um lugar encantado, que pertence à segunda parte da coletânea.

A presente dissertação não enfocou alguns elementos da poética do gótico. Particularmente, o componente onírico do desenvolvimento do enredo gótico (sonhos, visões, alucinações, efeitos de embriaguez) foi deixado fora dessa pesquisa. Com a introdução do sonho e dos outros estados do espírito fronteiriços, o princípio místico penetra o enredo. $\mathrm{Na}$ poética do gênero, o sonho aparece como mais um tipo de fronteira entre a vida e a morte, se 
transforma em uma parte do outro espaço e da outra existência, em que os fenômenos fantásticos se concretizam. Parece simbólica a frase de Danilo, de A Terrível Vingança: Sim, os sonhos dizem muitas verdades ${ }^{638}$. O aspecto pouco explorado desse tema, no contexto da poética do gótico, abre a possibilidade para a sua pesquisa ulterior.

A segunda questão que foi abordada apenas de um modo parcial nessa dissertação é o tema do tempo: como sucessão dos acontecimentos no enredo e como um ambiente. O passado, que contém alguns segredos familiares ou um crime não desvendado, define o desenrolar dos acontecimentos no presente. O tempo gótico é confuso, não é linear. Ele possui um caráter retrospectivo: o passado entra no presente de vários modos. A organização retrospectiva do tempo, no romance gótico, combina também com as menções aos eventos futuros que aparecem por meio dos sonhos e das profecias. Além disso, às vezes, existe o decorrer paralelo dos eventos independentes, o decurso dos eventos interrompidos, até uma parada no tempo. A confusão do tempo cronológico é um dos elementos do conceito gótico de ligação acentuada entre o passado, o presente e o futuro. O tempo gótico também é intensificado, quer dizer, o tempo factual do enredo não é o mesmo que o dos acontecimentos que o formam. Um dos procedimentos para essa intensificação do tempo cronológico é uma indicação direta ou indireta ao tempo da vida dos heróis, o efeito que cria no leitor o sentimento de uma sucessão e ligação constante entre o passado e o presente. O estudo desse problema exige o aprofundamento no tema da formação do cronotopo gótico, o que também pode ser realizado no futuro.

Escritor multifacetado, Gógol aplica os elementos da poética do gótico em sua obra de um modo criativo e extraordinário. Os temas tradicionais góticos complementam as outras camadas culturais dos seus textos, tais como romantismo, folclore eslavo, religiosidade ortodoxa, barroco, e muitas outras. O uso do princípio gótico serve, nas novelas ucranianas, para a compreensão dos conceitos de fé e de pecado, de vingança, do bem e do mal, da felicidade, da escolha, etc. Na obra gogoliana, os elementos da poética do gótico servem para uma interpretação filosófica aprofundada desses problemas.

${ }^{638}$ GÓGOL, 1990, p. 54. 
PARTE II 


\section{Breve resumo das novelas}

As novelas A Terrivel Vingança e A Carta Perdida já são traduzidas para português ${ }^{639}$. Porém, faz-se necessário colocar os resumos no corpo da presente dissertação, para facilitar o trabalho com os textos.

\section{A Terrível Vingança}

Uma novela mais próxima da tradição gótica, A Terrível Vingança, publicada no segundo volume de Noites em 1832, trata de uma história do perecimento da família do cossaco Danilo Burulbach, destruída pelo seu maldoso sogro, um feiticeiro e um traidor da pátria. A narrativa começa em Kiev, numa festa do casamento do filho de um chefe militar Gorobietz. Entre os convidados estão a família do cossaco Danilo, que chegou a festa com sua jovem esposa e um filho. Os cossacos estão surpreendidos por não ver o genro de Danilo, que, recentemente, acabou de voltar, depois de 21 anos da ausência, das terras turcas.

Há, no casamento, boatos sobre a volta de um terrível feiticeiro, que aparece somente nos momentos de grandes infortúnios. De repente, quando o padre leva dois ícones para benzer os recém-casados, um dos cossacos na festa se transforma no horrível monstro. As pessoas imediatamente reconhecem nele o feiticeiro, que logo desaparece.

Danilo, com sua família, está voltando para a casa pelo rio Dnepr. A esposa de Danilo, Katerina, está lembrando as velhas lendas sobre o feiticeiro. Está assustada com seu aparecimento no casamento, mas o herói está mais preocupado com os polacos que estão de volta à guerra com os cossacos. Sobre isto, ele está pensando no momento em que eles passam pelo velho castelo, que antigamente pertencia ao feiticeiro, e pelo antigo cemitério, onde, como eles dizem, estão enterrados os ossos dos antecedentes pecadores do feiticeiro. Porém, as cruzes no cemitério estão balançando, debaixo da terra saem os mortos-vivos que estendem seus ossos para a lua e gemem. Acalmando seu pequeno filho, Danilo finalmente chega à sua casa.

De manhã, Danilo começa uma briga com o sombrio e malicioso sogro, o pai de Katerina. Os homens pegam primeiro os sabres e depois os mosquetes. Danilo está ferido, Katerina implora a ambos que parem, e, graças a isso, os cossacos chegam à paz. Logo Katerina conta para Danilo o estranho sonho que ela teve, no qual o sogro era aquele horrível

${ }^{639}$ GÓGOL, 1990; GÓGOL, 2014. 
feiticeiro. O protagonista desaprova os costumes do sogro, alheios à vida dos cossacos. Danilo suspeita que o sogro não é cristão. Depois do almoço, durante o qual o sogro recusa toda a comida tradicional ucraniana: galuchkas ${ }^{640}$, carne de porco, gorilka ${ }^{641}$, ele vai embora.

Danilo decide descobrir aonde vai o sogro e acaba perseguindo-o. Ao ver que o velho entrou no antigo castelo, Danilo sobe uma árvore para olhar o que ele faz lá dentro. O protagonista vê através da janela um quarto mágico, iluminado sem velas, com armas estranhas nas paredes e os morcegos voando sob o teto. $\mathrm{O}$ sogro entra o quarto e começa a falar feitiços. Naquele momento, toda sua aparência muda: ele se torna o feiticeiro, vestido de roupa turca. Ele invoca a alma de Katerina e exige que a ela largue Danilo e vire a sua esposa. A alma da mulher recusa, e Danilo, chocado pela sua descoberta, volta para casa, acorda Katerina e conta tudo para ela. Katerina, horrorizada, renuncia do seu pai-apóstata.

Danilo coloca o feiticeiro na prisão, mas não por causa da bruxaria, mas porque ele traiu sua pátria e tentou chegar a um acordo com os inimigos, os polacos. No dia seguinte, o herói planeja executar o traidor. O feiticeiro, porém, conversa em segredo com sua filha Katerina. Pede para ela a abrir a porta da sua prisão. Promete-lhe que mais adiante vai levar uma vida santa e rezar para Deus, numa tentativa de salvar sua alma pecadora. Katerina acredita e libera o seu pai, mas não conta nada para Danilo.

Como era esperado, os polacos chegam à Ucrânia e atacam as casas. Danilo entra na batalha e mata muitos inimigos, mas é assassinado pela bala atirada da arma do feiticeiro. Este não cumpriu sua promessa à filha e passou para o lado dos polacos. Embora o cossaco Gorobietz ajudasse a vencer a batalha contra os polacos, Katerina está inconsolável.

O feiticeiro volta às ruínas do seu castelo. De novo, ele começa a falar os feitiços, tentando convocar a alma da filha. Mas, em vez de Katerina diante dele, aparece um rosto desconhecido de um homem forte. Embora não terrível, provoca pavor misterioso no feiticeiro.

Katerina passa a morar na casa do cossaco Gorobietz, educando o filho. Uma vez ela acorda à noite depois de um horrível pesadelo. Nele, o feiticeiro matou seu filho. Logo descobre que o bebê está morto e enloquece. Ela procura seu pai por toda parte, a fim de matá-lo. Certa vez, chega a casa um cossaco desconhecido, pergunta sobre Danilo e chora ao saber da morte dele. Ele quer ver Katerina e conversar com ela sobre seu marido. Diz que Danilo pediu a ele que, em caso da sua morte, casar-se com Katerina. Nesse momento, a

\footnotetext{
${ }^{640}$ Prato ucraniano à base de bolinhos de massa cozidos em caldo.

${ }^{641}$ Vodca ucraniana.
} 
mulher reconhece no hóspede o feiticeiro e se atira com a faca contra ele, mas, ele próprio mata a sua filha e some de casa.

De repente, em Kiev começam a acontecer coisas estranhas - toda a terra está coberta de luz, da Criméia até as montanhas Cárpatos, onde se pode ver um cavaleiro sobre um cavalo enorme. $\mathrm{O}$ feiticeiro, que estava no meio do povo, viu o cavaleiro e reconheceu nele o homem desconhecido que ele viu durante sua feitiçaria. Com muito pavor ele sai correndo. Os terrores da noite estão perseguindo o feiticeiro, por isso, ele monta o cavalo e vai para Kiev, para os lugares santos. Vê um monge e pede a ele que reze para sua alma pecadora. Mas o monge abre um livro e vê que o feiticeiro é um pecador tão grande que nada pode fazer para salvá-lo. Encolerizado, o feiticeiro mata o monge. De novo, o feiticeiro tenta escapar, mas não importa aonde ele tenta ir, ele acaba por se aproximar das Cárpatos, local em que está esperando o horrível cavaleiro. Ele agarra o feiticeiro e mata-o. Depois da morte, o feiticeiro vê todos os mortos que levantaram de Kiev, das Cárpatos, de Gálitch, e o cavaleiro joga-o no abismo, onde todos os mortos cravaram nele seus dentes; com exceção de um, o mais horrível de todos, que não conseguia levantar da terra e apenas a sacudia com muita força, o que causou terremotos e matou muitas pessoas.

A narrativa acaba com a antiga canção de um bandurrista na cidade de Glúkhov. Ele canta sobre os tempos muito velhos, sobre a guerra do rei Stepan com os turcos e sobre os irmãos, os cossacos Ivan e Petró. Ivan conseguiu cativar o paxá turco e recebeu o prêmio do rei, que dividiu com seu irmão. Mas Petró estava com inveja, queria deixar todo o ouro para si mesmo, e, por isso, empurrou o irmão para o abismo. Depois da morte o Deus deixou para o Ivan a escolher a punição para seu irmão. Ivan amaldiçoou toda a descendência de Petró e desejou que o último do seu clã fosse um malvado nunca visto, e quando este chegasse ao fim da sua vida, Ivan apareceria do abismo, montado num cavalo, e o lançaria ao abismo, onde seus antecedentes iam roê-lo. Mas Petró não conseguiria se levantar e iria roer a si mesmo, desejando vingar-se sem poder fazê-lo. Deus ficou impressionado com uma vingança tão horrível, mas decidiu que iria cumprir a vontade de Ivan. 


\section{A Carta Perdida}

Provavelmente a mais folclórica das novelas aqui analisadas, A Carta Perdida, publicada no primeiro volume de Noites em 1831, trata de uma estória estranha que ocorreu com o avô de um dos narradores, o diácono Fomá Grigórievitch. O protagonista, o então jovem cossaco, recebe uma ordem do hetman ${ }^{642}$ para levar uma carta à tzarina russa. O herói costura a carta por dentro do seu chapéu para não perdê-la, tira o cavalo do estábulo e começa a sua viagem. No dia seguinte, ele chega à cidade de Konotop, onde, naquele dia, acontece uma feira. Nela, o protagonista de repente encontra o seu conterrâneo, um zaporójetz ${ }^{643}$. Rapidamente, ele trava amizade com ele e os amigos decidem continuar seu caminho juntos, acompanhados por mais um cossaco.

Quando anoitece, os novos amigos se encontram num campo escuro. O zaporójetz começa a sentir medo. Conta para os cossacos que tinha vendido sua alma ao diabo e que, nesse dia, o tinhoso iria levá-lo para o inferno. Pede aos cossacos que o ajudem a não dormir esta noite, para não deixar o diabo arrancar sua alma. Os amigos param seu caminho numa taberna e pedem vodca. Logo zaporójetz adormece e o mesmo acontece com outro cossaco. O herói tenta não dormir para guardar a alma do amigo, mas a maldita sonolência enevoava tudo na sua frente; suas mãos petrificaram; a cabeça tombou, e um sono profundo pegou-o de tal modo que ele caiu feito um morto ${ }^{644}$.

Quando o herói acorda de manhã cedo, ele descobre que seu amigo desaparecera, assim como seu cavalo e seu chapéu, em que estava a carta à tzarina. Chegando à conclusão de que o diabo furtou seu cavalo e a carta, o cossaco decide ir para o inferno. Pergunta às pessoas na taberna, mas ninguém sabe onde está. Finalmente, quem lhe ajuda é o taberneiro, depois que o protagonista lhe dá uma moeda de ouro. Ele explica o caminho para o inferno.

Seguindo as instruções do taberneiro, o cossaco logo se encontra na margem do rio, onde vê um grupo de pessoas estranhas, ao lado de uma chama. Quando tenta perguntar algo a eles, eles ficam calados. Finalmente, o protagonista joga todo o dinheiro que tem no fogo e acaba sentado no inferno, na mesa com os diabos e as bruxas.

"A tribo diabólica" oferece um acordo ao protagonista. Se ele quiser seu chapéu com a carta de volta, ele deve ganhar pelo menos uma das três partidas no jogo de cartas com eles.

\footnotetext{
${ }^{642}$ Chefe eleito do exército cossaco na Ucrânia desde o século XVI; a partir do século XVIII passou a ser governador da Ucrânia.

${ }_{643}$ Cossaco, membro da Zaporójskaia Sietch, organização independente dos cossacos ucranianos, que existiu entre os séculos XVI e XVIII.

${ }^{644}$ GÓGOL, 2014, p. 99.
} 
As primeiras duas vezes, o herói perde, na terceira vez ele persigna as cartas com a cruz santa e logo ganha. Um trovão se espalha no inferno, as bruxas são atacadas por convulsões, e, repentinamente, aparece o chapéu. O herói exige também o seu cavalo de volta, mas diante dele aparecem somente seus ossos. Pede outro cavalo para escapar do inferno. Os diabos lhe dão um cavalo voador. Durante a viagem muito assustadora, o herói perde a consciência e volta a si somente no telhado de sua própria casa. Suas mãos e o rosto estão cobertos de sangue. Decidindo benzer sua casa quando voltar, o herói recomeça sua viagem e rapidamente entrega a carta à tzarina. Mas como ele se esquece de benzer a casa, às vezes, coisas estranhas acontecem com sua esposa. 


\section{Novelas traduzidas para português}

\section{Sobre a tradução}

A presente tradução de $A$ noite da véspera do dia de Ivan Kupala e de Uma noite de maio, ou uma moça afogada teve como objetivo preencher as lacunas no conhecimento da fase ucraniana da obra gogoliana no Brasil.

Totalmente inéditas em português, ou seja, nem mesmo em tradução indireta, as novelas servem como uma introdução à obra do jovem escritor, até agora não devidamente pesquisada no país.

Noites em uma granja perto de Dikanka não são completamente desconhecidas ao leitor brasileiro: das oito há, pelo menos, três novelas que foram traduzidas do russo nos últimos 20 anos. Além de $A$ Terrível Vingança, traduzida por Arlete Cavaliere e já amplamente citada no presente trabalho, existe uma tradução de A Noite de Natal, de Paulo Bezerra, recentemente revisada e publicada ${ }^{645}$. Também Tatiana Belinky fez uma tradução, direcionada ao público infanto-juvenil, incompleta, da novela A feira de Sorótchintsy ${ }^{646}$. Porém, a coletânea, como um todo, nunca foi traduzida no Brasil, e, por isso, nunca foi sujeita a uma análise mais profunda.

Para que a tradução pudesse ser realizada, foi imprescindível a consulta a diversos dicionários, principalmente ao Dicionário da língua grã-russa viva, de V. Dal ${ }^{647}$, e também ao Dicionário da língua russa, de S. Ójegov ${ }^{648}$. Foram bastante proveitosos para nós os dois glossários, feitos pelo próprio Gógol nos prefácios a duas partes de Noites em uma granja, assim como algumas observações em Kniga vsiákoi vsiátchiny ${ }^{649}$ (Livro de toda variedade), um caderno de notas em que Gógol, desde os dezessete anos, registrava as anedotas, provérbios, descrições dos costumes, lendas e os diferentes rituais das festividades populares, bem como os diferentes jogos e os textos das canções.

Entre as dificuldades encontradas no texto, citamos a grande quantidade de "ucranismos", a maioria deles - palavras relacionadas à vida cotidiana dos camponeses da

\footnotetext{
${ }^{645}$ GÓGOL, 2010.

${ }^{646}$ GÓGOL, Nikolai. A feira anual de Sorotchinski. Trad. de Tatiana Belinky. São Paulo: Ática, 1995.

${ }^{647}$ DAL', V. I. Tolkóvyi slovar'jivovo velikorússkovo iazyká. Em 4 tomos. Moskvá: Drofá, 2011.

${ }^{648}$ ÓJEGOV, S. I. Slovar' rússkovo iazyká. Moskvá: Rússki Iazyk, 1990.

${ }^{649}$ GÓGOL, N. V. Kniga vsiákoi vsiátchiny, ili podrútchnaia èntsiklopédiia. In sotchinénii v 14 tomakh. Moskvá-Leningrad: 1937-1952. Tomo 9. 1952, pp. 495-538. Pólnoe sobránie
} 
Ucrânia, cujos contextos e significados são muito distantes da cultura brasileira. São, por exemplo, zaporójetz - cossaco, membro da Zaporójskaia Siétch, organização independente dos cossacos ucranianos, que existiu entre os séculos XVI e XVIII; kutiá - um tipo de pudim doce de trigo e papoula, tradicional das cozinhas eslavas; kontuzs - um tipo de peça externa do vestuário masculino ou feminino, uma roupa longa, geralmente com o comprimento abaixo dos joelhos, com uma série de botões decorados colocados na parte inferior da frente, com as mangas compridas e largas. Pela dificuldade em traduzir essas palavras sem perder a parte do seu significado, optou-se por mantê-las transliteradas, acompanhadas pelas explicações nas notas do rodapé.

Além disso, há, na obra gogoliana, muitas metáforas, epítetos e expressões idiomáticas, para as quais não foi sempre fácil achar uma tradução adequada na língua portuguesa. Foi seguido o princípio de localizar a expressão idiomática quando possível, ou então, tentar procurar a expressão parecida com o mesmo sentido, ou, quando incompatível com o texto de Gógol, inventar uma tradução própria, seguida por uma explicação em nota de rodapé.

A presente tradução tentou manter a complexidade da estrutura da frase gogoliana, com seus longos períodos, com suas comparações e desvios explicativos, quando possível.

O texto original utilizado para a tradução encontra-se em Gógol N.V. Pólnoe sobranie sotchniénii $v 7$ tomakh. Volume I. Moskvá: Khudójestvennaia literatura, 1976. Foi também feito o cotejo da tradução inglesa, feita por Constance Garnett, no livro The complete tales of Nikolai Gogol ${ }^{650}$.

\footnotetext{
${ }^{650}$ The complete tales of Nikolai Gogol. Edited, with an introduction and notes, by Leonard J. Kent. Trad. de Constance Garnett. Chicago-London, The University of Chicago press, 1985. Vol. I.
} 


\title{
A Noite na véspera do dia de Ivan Kupala ${ }^{651}$
}

\author{
Um causo narrado pelo diácono da igreja de ***
}

Fomá Grigórievitch tinha uma peculiaridade bem singular: ele detestava repetir a mesma coisa. Por vezes, se alguém lhe implorasse para narrar alguma história novamente veja só- já metia algo novo ou a modificava tanto que nem dava para reconhecê-la. Uma vez um senhor arrancou esta mesma história de Fomá Grigórievitch, da qual nem se lembrava mais. Para nós, gente simples, fica até complicado nomear esses senhores, pois escribas não são, mas são como revendedores nas nossas feiras: apanham, mendigam, furtam de montão, e publicam todos os meses ou todas as semanas livrinhos não mais grossos do que uma cartilha. Um dia chega de Poltava o mesmo polonês de caftan cor de ervilha-verde ${ }^{652}$, do qual eu falava antes e de quem vocês, creio eu, já leram uma novela ${ }^{653}$, traz consigo um livrinho, abre-o na metade e o mostra para nós. Fomá Grigórievitch já estava pronto para acavalar os óculos sobre o seu nariz, mas, como lembrou que se esquecera de consertá-los com fio e cera, passou o livro para mim. Eu, visto que conheço um pouco a gramática e não uso óculos, pus-me a ler em voz alta. Mal acabara de virar duas páginas quando ele, de repente, me agarrou pela mão.

- Espere! Primeiro me diga, o que o senhor está lendo?

Admito que fiquei um pouco estupefato com uma pergunta dessas.

- Como "o quê", Fomá Grigórievitch? O seu causo, as suas próprias palavras.

- Quem disse ao senhor que estas são as minhas palavras?

- Mas que melhor prova o senhor quer, aqui está impresso:"narrado pelo diácono tal".

- Cuspam, então, na cabeça daquele que imprimiu isso! Está mentindo, moscal ${ }^{654}$ filho da mãe! Não foi assim que eu contei. Parece que alguém tem um parafuso a menos na cabeça! $!^{655}$ Escutem, vou contar tudo agora.

Nós nos aproximamos da mesa e ele começou.

${ }^{651}$ O dia de Ivan Kupala, ou Ivánov den' (O dia de Ivan) é uma festa popular eslava de origem pagã, comemorada na noite de 23 para o 24 de junho (hoje - de 6 para o 7 de julho). Os eslavos tinham a crença de que somente neste dia florescia a flor mítica de samambaia. Eles acreditavam que a pessoa que conseguisse colher essa flor poderia obter várias forças extraordinárias, entre as quais a habilidade de entender a língua dos animais e encontrar tesouros escondidos debaixo da terra. Mas, para colher a flor, a pessoa tinha de superar o medo que os demônios suscitavam nela.

${ }^{652}$ Uma alusão à expressão popular russa chut gorókhovyi, literalmente - "palhaço de ervilha", que significa uma pessoa vazia, que não presta para nada.

${ }^{653}$ Gógol fala sobre a "Sorótchinskaia iármarka" (A feira de Sorótchintsy), que foi publicada em 1831 na primeira parte de Noites em uma Granja, cujo narrador é o polonês.

${ }_{654} \mathrm{Moscal}$ - alcunha que os ucranianos usavam para qualquer russo. No original, toda a frase está em ucraniano.

${ }^{655} \mathrm{O}$ itálico refere-se às frases em ucraniano. 
O meu avô (que Deus o tenha! Que no outro mundo coma somente pães de trigo e pães de mel com sementes de papoula!) era um contador de histórias maravilhoso. Às vezes, começava a falar e a gente tinha vontade de ficar o dia inteiro no mesmo lugar, só escutando. Nem se compara a um bufão qualquer de hoje, que logo começa a falar patranhas, como algum moscal, com a língua como se não comesse há três dias, assim é melhor pegar o chapéu e sair de casa. Lembro como se fosse hoje (a velha, minha finada mãe, era ainda viva) que numa longa noite de inverno, quando no quintal o frio estava de rachar e tapava densamente a vidraça estreita da nossa casa, a mãe estava sentada em frente à penteadeira, esticando com as mãos um fio comprido, balançando o berço com o pé e cantando uma canção que até parece que estou ouvindo agora. A luminária, tremendo e se inflamando, como se estivesse assustada com algo, iluminava a casa para nós. O fuso de fiar zumbia e todos nós, as crianças, reunidas em grupinho, escutávamos o avô que, de tão velho, não descia do leito na sua pétch ${ }^{, 656}$ fazia cinco anos. Mas nem suas palavras encantadoras sobre os velhos tempos, sobre as marchas dos zaporójetz ${ }^{657}$, sobre os polacos, sobre as façanhas valentes de Podkova ${ }^{658}$, Poltorá Kojukhá $^{659}$ e Sagaidátchnyi ${ }^{660}$ atraíam tanto nossa atenção quanto as histórias sobre acontecimentos antigos e estranhos, as quais nos davam arrepios por todo o corpo e deixavam o cabelo de pé. De vez em quando, um medo nos pegava tanto, que, à noite, tudo parecia Deus sabe lá que monstro. Se, à noite, acontecer de você sair de casa por alguma razão, logo pensa que um habitante do outro mundo deitou na sua cama. E juro de pés juntos que até muitas vezes confundia o próprio camisolão, colocado na cabeceira, achando que o diabo se aconchegara ali. Mas o essencial nas histórias do avô era que ele nunca mentira em toda sua vida, e o que ele, às vezes, dizia era exatamente o que tinha acontecido. Vou contar para vocês agora uma das suas histórias maravilhosas. Sei que se pode encontrar com abundância sabichões que escrevinham nas cortes e até leem em língua oficial ${ }^{661}$ e que, se lhes derem um simples livro sagrado, nem entenderiam um A sequer, mas, para arreganhar os dentes sem

\footnotetext{
${ }^{656}$ Petch' - fogão a lenha típico russo, usado não só para preparar e aquecer comida, mas também para esquentar toda a casa; as pessoas usavam sua superfície como leito.

${ }^{657}$ Zaporójetz - cossaco, membro da Zaporójskaia Siétch, organização independente dos cossacos ucranianos que existiu entre os séculos XVI e XVIII.

${ }_{658}^{65}$ Podkova Ivan - líder dos cossacos que, em 1577, conquistou o trono da Moldávia. Em 1578, foi executado.

${ }^{659}$ Poltorá Kojukhá Karp - hetman ucraniano que comandou entre os anos 1638 e 1642.

${ }^{660}$ Sagaidátchnyi (Conachévitch) Piótr - hetman ucraniano que, em 1616-1621, comandava as marchas dos zaporójetz contra os turcos.

${ }^{661}$ Língua oficial (em russo - grajdánskaia gramota), foi introduzida na Rússia por Pedro o Grande, em 1708, para imprimir livros laicos, revistas e jornais. Surgiu como resultado da primeira reforma do alfabeto russo, isto é, a redução da quantidade e a simplificação da grafia das letras. Em oposição a ela, coexistiu, por muito tempo, a língua eslava eclesiástica, mais difícil para ler e escrever, era utilizada, exclusivamente, para a literatura religiosa.
} 
vergonha, eles têm aptidão. Tudo o que contar lhes causará risos. Tanta é a falta de fé que se espalhou pelo mundo! O que mais dizer - juro pelo amor de Deus e a Santíssima Virgem! vocês, talvez, nem acreditem: certa vez abri a boca para falar sobre as bruxas - e aí? apareceu um imprudente que não acredita em bruxas! Eu, graças a Deus, moro há tanto tempo neste mundo e vi tantos incrédulos que seria mais fácil eles levarem um sacerdote na lábia do que cheirarmos um rapé ${ }^{662}$; mas até eles faziam o sinal da cruz de medo das bruxas. Mas que eles sonhem com... apenas não estou com vontade de pronunciar com o quê, não se deve até falar sobre eles.

Há - quantos? - mais de cem anos atrás, contava o meu falecido avô, ninguém reconheceria a nossa aldeia: era uma granja, uma granja das mais pobres! Umas dez casinhas, nem rebocadas nem protegidas, brotavam aqui e acolá no meio do campo. Não havia nenhuma cerca, nenhum palheiro decente onde se pudesse colocar uma vaca ou uma carruagem. E, assim, viviam os ricos, e, se vocês olhassem para gente como nós, para os pobres, veriam um buraco cavado na terra - e pronto, ali estaria uma casa! Apenas pela fumaça se poderia adivinhar que lá vive um homem de Deus. Vocês vão perguntar por que razão eles viviam assim. Não é que fossem pobres, pois naquele tempo quase qualquer um que fosse cossaco trazia muitos bens das terras estrangeiras, mas o fato era que não adiantava arranjar uma casa decente. Quanta gente vagueava naquele tempo em todos os lugares: o povo da Criméia, os polacos, os lituanos! Acontecia que até os próprios vizinhos chegavam em bando e assaltavam os conterrâneos. Acontecia de tudo.

Nessa mesma granja, aparecia, com frequência, um homem, ou, melhor dizendo, um diabo de aparência humana. De onde ele vinha, para quê, ninguém sabia. Patusca, farreia e, subitamente, some sem deixar vestígios, nem dar notícias. Mas, de repente, olha só, de novo apareceu, como caído do céu, perambula pelas ruas da aldeia da qual agora não existe nem rastro e que se encontrava, talvez, a não mais de cem passos de Dikanka.Vai reunir os cossacos transeuntes: a gargalhada e a cantoria não cessam, o dinheiro chove; a vodca flui que nem água... Assediará, às vezes, as moças bonitas: vai presenteá-las com fitas, brincos, colares - não há mais onde colocá-los! É certo que as moças bonitas hesitavam um pouco em aceitar os presentes: Deus sabe, talvez de verdade, tivessem passado por mãos impuras. A própria tia do meu avô, que naquele tempo era dona da taberna na atual estrada de Opochniá, onde frequentemente farreava Bassavriuk (assim eles chamavam esse homem demoníaco), dizia justamente que não aceitaria presentes dele nem por todas as riquezas do mundo. Por

\footnotetext{
${ }^{662}$ No original, provozit' popá v recheté, literalmente - levar um sacerdote numa peneira, que significa mentir na confissão (Comentário de N.V. Gógol).
} 
outro lado, como não aceitar? Qualquer um ficará com medo quando, às vezes, ele enrugar suas sobrancelhas hirsutas e lançar de soslaio um olhar que fazia qualquer um dar no pé, Deus sabe para onde. E se você aceitar, já na noite seguinte, lhe faz uma visita algum "amigo" do pântano, arrastando-se, com cornos na cabeça e apertando seu pescoço, se nele houver um colar; mordendo seu dedo, se nele houver um anel; ou puxando sua trança, se nela tiver enrolada uma fita. Que Deus, então, nos livre desses presentes! Mas - infelizmente - não tem jeito de se livrar deles: se os jogar na água, o anel diabólico ou o colar flutuam e acabam logo em suas mãos.

Havia, na aldeia, uma igreja, se eu me lembro bem, de São Pantaleão. Morava ao lado dela um sacerdote, o padre Afanássi, de saudosa memória. Ao notar que Bassavriuk não estava na igreja nem no santo Domingo de Páscoa, teve a intenção de repreendê-lo e lhe impor a penitência. Tudo em vão -ainda ficou com as pernas quebradas! "Escuta aqui, pan ${ }^{663}$ ! - trovejou em resposta. - melhor que cuide da sua vida em vez de se meter na vida dos outros, se não quiser que sua garganta de bode seja tapada com uma kutiá ${ }^{664}$ quente!”. O que fazer com o maldito? Padre Afanássi anunciou, apenas, que qualquer um que se tornar amigo de Bassavriuk será considerado um católico, um inimigo da igreja de Cristo e de todos os seres humanos.

Naquela aldeia um dos cossacos, chamado Korj, tinha um criado que a gente apelidava Petró Sem-Família; talvez porque ninguém se lembrasse nem do pai, nem da mãe dele. É verdade que o curador da igreja costumava dizer que eles haviam morrido de peste no mesmo ano; mas a tia do meu avô não queria saber disso e fazia de tudo para lhe dar parentes, mesmo que o pobre Petró tivesse tanta necessidade deles como nós temos das nuvens de antanho. Ela dizia que o seu pai estava em Zaporójie, antes disso - caíra prisioneiro dos turcos, sofrera Deus sabe que tormentos e, por algum milagre, tendo se disfarçado de eunuco, dera no pé. As belas moças de cabelo negro e as jovens pouco se importavam com os seus parentes. Diziam somente que ele colocaria todos os rapazes daquele tempo no chinelo se the vestissem um jupan ${ }^{665}$ novo, o apertassem com um cinto vermelho, lhe pusessem na cabeça um chapéu feito de smuchkas ${ }^{666}$ pretas com uma elegante copa azul, pendurassem uma espada turca na anca e colocassem uma chibata numa mão e na outra um cachimbo de aro bonito. Mas, infelizmente, o pobre Petró tinha apenas um camisolão cinza com mais buracos do que moedas de ouro nos

\footnotetext{
${ }^{663}$ Pan utiliza-se como forma de tratamento para a nobreza na Polônia e Ucrânia antigas ("senhor").

${ }^{664}$ Kutiá - um tipo de pudim doce de trigo e papoula, tradicional das cozinhas eslavas.

${ }^{665}$ Jupan - antiga veste masculina superior usada por ucranianos e poloneses.

${ }^{666}$ Smuchka - pele de cordeiro da raça do mesmo nome.
} 
bolsos de algum judeu. E isso nem era a maior desgraça. A desgraça era a seguinte: o velho Korj tinha uma filha tão bela que eu duvido que vocês já tenham tido chance de ver algo parecido. A tia do meu falecido avô contava (e para uma mulher, como vocês sabem, é mais fácil beijar o diabo, sem maldade, do que chamar outra mulher uma beldade) que as bochechas rechonchudas da cossaca eram rosadas e ardentes como uma papoula cor-de-rosa mais suave, quando, depois de se lavar com o orvalho de Deus, ela brilha, endireita as folhinhas e se apruma perante o sol nascente; suas sobrancelhas eram como as cordas negras (as nossas moças hoje as compram para pendurar as cruzes e os ducados dos moscais que passam pelas aldeias com caixas) que se curvam corretamente, como se mirassem nos seus olhos claros; a sua boca pequena, para a qual os jovens daquele tempo olhavam gulosamente, parecia que fora feita para trinar canções do rouxinol; seu cabelo, negro como as asas de uma graúna e macio como linho novo (naquele tempo as nossas moças ainda não se enfeitavam com tranças finas, entrelaçando-as com fitas estreitas, bonitas e coloridas), caía em forma de caracóis crespos sobre o kontusz ${ }^{667}$ bordado de ouro. Ah, que o senhor não me deixe mais cantar o Aleluia no coro da igreja se não é verdade que eu, neste mesmo lugar, a cobriria de beijos, apesar de que fios grisalhos estão se infiltrando por toda a velha floresta que brota do meu cocuruto, e ainda, bem ao lado, está a minha velha, como uma pedra nos sapatos. Então, quando, em algum lugar, um rapaz e uma moça vivem perto um do outro... vocês todos sabem o que acontece. Às vezes, ao romper da aurora, as marcas dos saltos das botas vermelhas eram visíveis onde Pidorka tagarelava com seu Petró. Contudo, não teria vindo à mente de Korj nenhuma má intenção se uma vez (aí, é claro como água que não fora outro senão o tinhoso que tentou) não viesse à cabeça de Petró, sem pensar bem, na entrada da casa, lascar um beijo - como eles dizem - de todo o seu coração, nos lábios rosados da cossaca. Aquele mesmo tinhoso (que ele, o filho de uma égua sonhe com a santa cruz!) levou o velho caduco a abrir a porta da casa, de bobeira. Korj, estupefato, ficou boquiaberto e agarrou a porta com a mão. O maldito beijo, ao que parecia, o ensurdecera por completo. Ele pareceu-lhe mais alto que a batida do pilão na parede, com o qual, geralmente, o mujique, no nosso tempo, afugenta a kutiá $^{668}$, por falta de fuzil e pólvora.

\footnotetext{
${ }^{667}$ Kontusz - um tipo de peça externa do vestuário masculino ou feminino. Era uma roupa longa, geralmente com o comprimento abaixo dos joelhos, com uma série de botões decorados colocados na parte inferior da frente. As mangas eram compridas e largas.

${ }^{668}$ Após todas as festas natalinas, o dia 18 de janeiro, na religião ortodoxa, foi considerado um dia de rigoroso jejum. Nesse dia, os russos e os ucranianos, antigamente, praticavam, para afastar de casa as forças malignas, vários ritos. Entre eles, existia o rito de "afugentar a kutiá". Os jovens da casa batiam com um pilão nos portões, quebravam potes e atiravam com uma espingarda três vezes no ar, o que simbolizava a despedida das almas dos mortos para que elas não prejudicassem os vivos.
} 
Ao voltar a si, ele tirou da parede o chicote do seu avô e já estava pronto para açoitar as costas do coitado do Petró quando, não se sabe de onde, chegou correndo o irmão de Pidorka - Ivás - e, apavorado, agarrou com as mãozinhas as pernas dele, gritando: "Papai, papai! Não bata em Petró!”. O que se vai fazer? Coração de pai não é de pedra: ao pendurar o chicote de volta na parede, ele o acompanhou às escondidas fora da casa: "Se você aparecer na casa outra vez, mesmo que só debaixo das janelas, aí, escuta, Petró, juro por Deus que esse seu bigode negro vai sumir, assim como o seu oselédets ${ }^{669}$ que já está enrolado duas vezes em torno da sua orelha; que eu não me chame Terénti Korj se ele não disser adeus ao seu cocuruto!". Ao dizer isso, lhe deu de leve um tabefe na nuca, e foi assim que Petró caiu, com todo o seu peso, no chão. E lá se foram para a cucuia os beijos! Uma tristeza pesada assolou os nossos pombinhos; e ainda se espalhou o rumor pela aldeia que pegou o hábito de visitar Korj algum polaco com roupa bordada de ouro, de bigode, com sabre, esporas, e os bolsos tilintando como a sineta do saquinho com que o nosso sacristão, Taras, dá uma volta todo dia pela igreja. Pois bem, sabe-se para que visitam um pai quando há uma filha de cabelos negros. Então, um dia, Pidorka, cheia de lágrimas, pegou no colo o seu Ivás: “Ivás, meu bem, Ivás, meu querido! Corra à casa de Petró, minha criança preciosa, como uma flecha atirada de um arco; conta tudo para ele: que amaria seus olhos castanhos, beijaria seu rosto branco, mas o meu destino não me permite. Inundei em lágrimas amargas não apenas uma toalha. Não aguento. Tenho um peso no coração. E meu próprio pai é o meu inimigo: está forçando-me a casar-me com um polaco que não amo. Diga para ele que já estão preparando o casamento, só que não vai haver música nesse casamento: os diáconos vão cantar, em lugar das cobzas ${ }^{670} \mathrm{e}$ sopilkas $^{671}$. Não vou dançar com meu noivo; me carregarão. Escura, escura será a minha casa - feita de madeira de pinos, e no lugar da chaminé, a cruz vai ficar fincada no telhado!”.

Como se estivesse petrificado, sem sair do lugar, Petró escutava enquanto a criança inocente lhe murmurava as palavras de Pidorka. "E eu, desgraçado, pensava em ir à Crimeia e à Turquia ganhar ouro na guerra e, com os bens, voltar para você, minha beldade. Mas não era para ser assim. O mau olhado nos pegou. Vou já, meu querido peixinho, vou também a um casamento: só que não vai haver diáconos nesse casamento; o corvo negro crocitará em vez do sacerdote, em cima de mim; o campo será minha casa; a nuvem cor de chumbo, meu telhado; a águia arrancará meus olhos castanhos; as chuvas lavarão meus ossos de cossaco e o

\footnotetext{
${ }^{669}$ Oselédets - madeixa de cabelos no topo da cabeça, típica dos cossacos.

${ }^{670}$ Cobza - instrumento musical popular de oito cordas.

${ }^{671}$ Sopilka - instrumento musical popular parecido com uma flauta.
} 
torvelinho os secará. Mas por quê? De quem? A quem reclamar? Assim, parece, era vontade de Deus, -perdido eu estou, então!". E caminhou direto para a taberna.

A tia do meu falecido avô se surpreendeu um pouco ao ver Petró na taberna - e ainda na hora em que uma boa alma vai às matinas- e esbugalhou os olhos, como se acabasse de acordar, quando ele pediu uma caneca com pouco menos de meio litro de aguardente. Mas em vão o coitado pretendia afogar suas mágoas. A vodca picava sua língua como urtiga e lhe parecia mais amarga que losna. Jogou a caneca no chão. "Chega de se afligir, cossaco!", trovejou alguém em voz grave em cima dele. Olhou para trás: era Bassavriuk! Ah! Que carranca! O cabelo como as cerdas, os olhos como os de um touro! "Sei o que te faz falta: isto aqui!" Aí, ele fez tilintar com um sorriso demoníaco um porta-moedas de couro, que estava pendurado em seu cinto. Petró estremeceu. "He-he-he! Olhe como arde!"- urrou ele passando as moedas de uma mão para outra.- "He-he-he! Escute como tilinta! E apenas um favor vou exigir de você por um monte de bugigangas assim!". "Diabo!” - gritou Petró. - "Vamos! Estou pronto a fazer qualquer coisa!". Chegaram a um acordo com um aperto de mãos. "Olha, Petró, você chegou na hora certa: amanhã é dia de Ivan Kupala. Somente nesta noite do ano a samambaia floresce. Não deixe passar! Vou te esperar à meia-noite em Medvéji Ovrag ${ }^{672}$."

Acho que até mesmo as galinhas não se exasperam tanto antes da baba trazer-lhes os grãos de trigo, quanto Petró ao esperar a noite. A cada momento examinava se a sombra das árvores havia se tornado mais comprida, se o solzinho, baixando, estava ficando rosado, e quanto mais examinava, com menos paciência ficava. Que demora! Pelo visto, o dia do Senhor perdera seu fim em algum lugar. Finalmente o sol desaparece. Apenas o céu avermelha-se de um lado. E já está empalidecendo. No campo, começa a ficar mais frio. Está escurecendo, escurecendo e escureceu. Até que enfim! Com o coração por pouco a sair pela boca, se arrumou para o caminho e com cautela desceu atravessando a densa floresta no profundo vale chamado Medvéji Ovrag. Bassavriuk já o aguardava ali. Está tão escuro que não se pode enxergar um palmo à frente do nariz. De mãos dadas, eles se enfiaram pelos pântanos lamacentos, emaranhando-se nos abrunheiros que cresciam densamente e tropeçando quase a todo passo. Finalmente alcançam um lugar plano. Petró olhou ao redor: nunca tivera a chance de passar por ali. E ali mesmo Bassavriuk parou.

- Olhe, está vendo as três colinas diante de você? Nelas haverá muitas flores diferentes; mas nem pense em arrancar uma delas sequer. Logo que a samambaia florescer, colhe-a e não olhe para trás, independente do que parecer.

$\overline{{ }^{672} \text { Literalmente, Barranco do Urso. }}$ 
Petró queria perguntar mais alguma coisa... mas, dá uma olhada e - ele já não estava lá. Aproximou-se das três colinas; mas onde estão as flores? Não se enxerga nada. As ervas daninhas negrejavam ao redor e sufocavam tudo com sua densidade. Mas logo no céu surgiu uma fulguração e, na frente dele, apareceu um canteiro inteiro de flores, todas maravilhosas, todas jamais vistas antes; no mesmo lugar, as folhas de uma simples samambaia. Petró ficou na dúvida e parou pensativo diante delas, encostando ambas as mãos nas ancas.

- O que tem de maravilhoso aqui? Vejo esta planta inútil dez vezes por dia; o que tem de tão especial? Será que essa besta do diabo está zombando de mim?

De repente, vê um pequeno botão avermelhando-se, era como se estivesse vivo, mexendo-se. É maravilhoso de verdade! Está se mexendo e ficando maior, maior e avermelhando como uma brasa quente. A estrelinha se inflamou e algo começou a crepitar fracamente e uma flor se abriu diante de seus olhos como uma chama, iluminando as outras ao seu redor.

“Agora é a hora!" - pensou Petró e estendeu sua mão. Vê atrás de si que centenas de mãos peludas também se estendem em direção à flor, e, por trás, algo corre de um lugar para outro. Semicerrando os olhos, deu uma puxada na haste, e a flor foi parar em suas mãos. Tudo ficou em silêncio. No cepo, apareceu Bassavriuk sentado, todo azul como um morto. Não mexia nem um dedo. Seus olhos estão cravados em algo visível só para ele; sua boca semiaberta, e nenhuma palavra sai dela. Ao redor, nada se mexe. Ah, que horror!.. Mas, aí, ouviu-se um assobio, que congelou Petró por dentro, e lhe pareceu que a grama arramalhava, as flores começavam a conversar entre si com uma voz fininha como campainhas de prata; as árvores ribombaram com uma chuva de xingamentos... O rosto de Bassavriuk, de súbito voltou à vida; seus olhos faiscaram. "Afinal, veio a bruxa!” - resmungou ele entre dentes. "Olhe, Petró, agora vai aparecer na sua frente uma beldade: faça tudo que ela ordenar, senão você estará perdido para sempre!". Neste momento, ele afastou com um pau nodoso um abrunheiro e diante deles surgiu uma isbazinha - como eles dizem - sobre patas de galinha. Bassavriuk deu um murro na parede, e a casa balançou. Um cachorrão preto saiu correndo em seu encontro e, com um ganido, se transformou numa gata e se lançou para arrancar os seus olhos. "Deixe, deixe de ser louca, velha diaba!" - dizia Bassavriuk, temperando a fala com tanto palavrão que uma pessoa de bem taparia os ouvidos. De repente, em vez de uma gata, surgiu uma velha com o rosto murcho como uma maçã cozida, toda dobrada, o nariz e o queixo como um alicate com o qual se quebram nozes. "Uma beldade gloriosa!" - pensou Petró, e arrepios passaram pelas suas costas. A bruxa arrancou a flor de suas mãos, inclinou- 
se e, por muito tempo, sussurrou algo a ela, salpicando-a com alguma água. Faíscas choveram da sua boca; uma espuma apareceu nos seus lábios. "Atire-a!" - disse ela passando a flor para ele. Petró atirou-a no ar e - que estranho? - a flor não caiu de imediato, mas por muito tempo parecia uma bolinha de fogo no meio da escuridão e, feito um barco, ficou flutuando no ar; finalmente, aos poucos, começou a descer ao chão e caiu tão longe que mal se via a estrelinha, não maior que uma semente de papoula. “Aqui!" - rouquejou a velha numa voz surda; e Bassavriuk, dando-lhe uma pá, acrescentou: "Cave aqui, Petró. Aqui vai ver tanto ouro como você e Korj jamais sonharam”. Petró, dando cusparadas nas mãos, pegou a pá, pisou nela e escavou a terra, uma vez, a segunda, a terceira, mais uma... Algo duro!... A pá tilinta batendo em algo e não penetra mais. Aí, seus olhos começaram a distinguir um cofre não muito grande, algemado com ferro. Quis alcançá-lo com a mão, mas o cofre começou a se aprofundar na terra, e quanto mais ele tentava, mais fundo ia, mais fundo; e, atrás dele, ouviase uma gargalhada, mais parecida com o chiado de uma cobra. "Não, não verás ouro até que obtenha sangue humano!" - disse a bruxa e conduziu até ele uma criança de uns seis anos coberta por um lençol branco, fazendo-lhe entender, por gestos, que ele precisava cortar a sua cabeça. Petró ficou petrificado. Não é uma piada cortar sem razão a cabeça de algum homem, e ainda de uma criança inocente! Encolerizado, ele tirou o lençol que cobria a cabeça do menino, e o que ele vê, então? Na frente dele, estava Ivás. A coitada da criança pôs as mãozinhas cruzadas e abaixou a cabeça... Furioso, ele deu um salto com a faca em direção à bruxa e até já levantara o braço para golpeá-la...

- E o que você prometeu pela moça? - troou Bassavriuk, como se atirasse uma bala nas costas de Petró. A bruxa bateu o pé: uma chama azul saiu da terra; o centro dela se iluminou e ficou fundido como cristal; e tudo o que havia debaixo da terra ficou claro como o dia. Moedas de ouro, pedras caras, nos cofres e nas caldeiras, estavam amontoadas exatamente debaixo do lugar onde eles estavam parados. Os seus olhos incendiaram-se... a mente se perturbou... Como um louco, ele agarrou a faca, e o sangue inocente esguichou em seus olhos... Uma gargalhada diabólica ribombou de todos os lados. Monstros repugnantes pulavam em matilhas perante ele. A bruxa, agarrando com as mãos o cadáver decapitado, tomava dele o sangue como um lobo... Tudo girava em sua cabeça! Juntando todas as forças, ele se pôs a correr. Tudo à sua frente ficou coberto de vermelho. As árvores, ensanguentadas, pareciam arder e gemer. O céu, incandescido, tremia... Manchas de fogo, feito relâmpagos, lhe apareciam aos olhos. Vencido pela força, entrou correndo na sua cabana e caiu de vez como uma pedra. Um sono mortal o arrebatou. 
Dois dias e duas noites dormiu Petró a sono solto. Ao voltar a si, no terceiro dia, por muito tempo perscrutava os cantos da sua casa; mas, em vão, tentava se lembrar de alguma coisa: sua memória era como o bolso de um velho forreta, de quem não se extorquiria nem um tostão. Ao se esticar um pouco, ouviu que algo tilintou a seus pés. Vê dois sacos de ouro. Apenas naquele momento, como em um sonho, ele se lembrou de que estava procurando algum tesouro, que estava com medo, sozinho no bosque... Mas a que custo, como aconteceu, isso ele não conseguia recordar de jeito nenhum.

Korj viu os sacos e enterneceu: "Petró, seu isso e aquilo! Será que não fui eu quem o amou? Será que ele não era meu próprio filho em minha casa?” - e o velho caduco começou a dizer asneiras, e até mesmo deixou cair uma lágrima. Pidorka começou a lhe contar que os ciganos que passaram por sua casa haviam sequestrado Ivás. Mas Petró nem conseguia se lembrar do rosto da criança: tanto o havia encantado o maldito feitiço demoníaco! Não havia mais razão para adiar. Mostraram o dedo ao polaco e começaram a preparação para o casamento: assaram um monte de pães nupciais, coseram toalhas e lenços, rodaram um barril de aguardente; sentaram à mesa os recém-casados, cortaram um pão redondo; atacaram as cordas das bandurras, os címbalos, as sopilkas, as cobzas - e começou a diversão...

Nos velhos tempos, o casamento era incomparável ao atual. A tia do meu avô, às vezes, contava - era uma maravilha só! As moças, com cabeça enfeitada de fitas amarelas, azuis e rosas, em cima das quais se atava um cadarço dourado, de camisetas finas bordadas em todas as costuras com um fio de seda vermelha e adornadas com pequenas florzinhas de prata, de botas de marroquim com altas ferraduras, dançavam a górlitsa ${ }^{673}$ graciosamente, como as pavoas, ou ruidosamente como um tufão. As recém-casadas, endireitando-se com ar de importância, pavoneavam-se uma a uma e, em ritmo, batiam a gopak ${ }^{674}$, com barquinhos ${ }^{675}$ na cabeça, cujas copas foram todas feitas de brocado de fios dourados, com um pequeno recorte na nuca, de onde emergia uma touca dourada, com dois corninhos de smuchka preta mais fina; de kontuzs azuis, feitos da melhor seda, com as paletas vermelhas. Os rapazes, de altos chapéus de cossaco, de camisolões finos de feltro, apertados com cintos bordados de prata, com os cachimbos na boca, desfaziam-se em rapapés diante delas e tagarelavam. $\mathrm{O}$ próprio Korj não aguentou ver os jovens e decidiu recordar os velhos tempos. Com a bandurra nas mãos, fumando seu cachimbo e, ao mesmo tempo, cantarolando, balançando um cálice

\footnotetext{
${ }^{673}$ Górlitsa - dança popular do século XIX, de origem polonesa. É dançada em par, de modo doce e lírico, com movimentos circulares.

${ }^{674}$ Gopak - dança popular ucraniana, masculina. Inclui pulos, prisiádkas, viradas.

${ }^{675}$ Barquinho é um tipo de chapéu que imita sua forma.
} 
sobre a cabeça, o velhão pôs-se a dançar a prisiádka ${ }^{676} \mathrm{com}$ um grito alto de farrista. O que as pessoas não inventam quando estão meio altas! Quando começam, às vezes, a pôr máscaras meu Deus, nem parecem pessoas! Já nem se compara com as fantasias que hoje acontecem nos nossos casamentos. O que fazem agora? - apenas se vestem de ciganas e moscais. Não, acontecia de um se fantasiar de judeu e outro de diabo, começar primeiro a se beijarem e depois agarrarem os topetes um do outro... Meu Deus! Tanto riso que dói a barriga. Vestiamse com roupas turcas e tártaras: tudo nelas ardia como fogo... E quando começam a fazer bobagens e pregar truques... então melhor virar os santos de costas. Com a tia do falecido avô, que estava presente naquele casamento, aconteceu uma coisa engraçada: naquele dia, ela estava vestida com uma roupa tártara bem folgada, e, com um cálice nas mãos, servia os convidados. E eis que o tinhoso tentou um dos presentes a borrifar as suas costas com vodca; o outro, ao que parece também um rapaz esperto, acendeu o fogo no mesmo minuto e a incendiou... a chama ardeu, a coitada da tia, assustada, pôs-se a tirar, na frente de todos, a roupa... O barulho, a risada, a confusão elevaram-se como em uma feira. Numa palavra, os velhos nunca tinham visto antes um casamento tão divertido.

Pidorka e Petró começaram a viver como um pan com uma pani. Tudo com abundância, todas as coisas brilham... Mas as pessoas de bem balançavam as cabeças um pouco em desaprovação ao observar a vida deles. "Do diabo não virá nada de bom!" - diziam elas em coro. - "De onde, senão do tentador de todos os seres ortodoxos, chegou a ele essa riqueza toda? De onde ele podia tirar um montão de ouro assim? Por que, de repente, no mesmo dia em que ele enriquecera, Bassavriuk sumiu sem deixar vestígios?”. E vocês dizem que as pessoas inventam coisas! Pois, de verdade, nem passou um mês, e já ninguém poderia reconhecer Petró. Por que, o que acontecera com ele, só Deus sabe. Fica sentado no mesmo lugar e não troca palavras com ninguém. O tempo todo fica refletindo como se quisesse lembrar algo. Quando Pidorka consegue forçá-lo a conversar sobre algo, parece estar distraído, começa a falar e até se anima; mas, sem querer, vai olhar para os sacos -"Peraí, peraí, esqueci!" - grita, e de novo fica pensativo, e de novo se esforça para lembrar alguma coisa. Por vezes, quando fica sentado por muito tempo no mesmo lugar, lhe parece que logo, logo tudo de novo virá à sua mente... mas, novamente, tudo some. Imagina estar na taberna; trazem-lhe vodca; a vodca o queima; a vodca lhe dá asco. Alguém se aproxima, bate em seu ombro... mas depois tudo fica como se fosse encoberto por uma névoa. Seu rosto sua em bagas, e ele, sem forças, volta a sentar no seu lugar.

\footnotetext{
${ }^{676}$ Prisiádka - dança típica russa e ucraniana que necessita de grande força nas pernas, consiste em pulos com flexão dos joelhos e no apoio do corpo nas pontas dos pés.
} 
O que não fazia Pidorka: consultava os curandeiros, tentara adivinhar o que havia causado sobressalto e fizera um chá de sono ${ }^{677}$ - nada ajudava. Assim passou o verão. Muitos cossacos ceifaram e colheram toda a safra; muitos, mais ousados que os outros, saíram na marcha. Bandos de patos ainda se amontoavam nos nossos pântanos, mas de toutinegras já não havia nem sombra. As estepes se avermelharam. Medas de trigo surgiam ora cá, ora lá, no campo como chapéus de cossacos. Apareciam no caminho carroças empilhadas de chamiço e lenha. A terra se tornou mais dura e, em alguns lugares, o frio começou a penetrá-la. Já a neve começou a cair do céu e os galhos das árvores se enfeitaram com a geada como uma pele de lebre. Já em um dia claro e gelado, um pisco-chilreiro de peito vermelho, como um nobre janota polonês, passeava pelos montes de neve, arrancando grãos, e as crianças com grandes tacos lançavam no gelo cubos de madeira, enquanto seus pais dormitavam em paz nos petch's, saindo de tempos em tempos com um cachimbo aceso na boca para, com gosto, maldizer o danado frio russo ortodoxo ou tomar o ar fresco e malhar na entrada o trigo que sobrara. Finalmente, a neve começou a derreter e, como eles dizem, o peixe quebrou o gelo do rio com o rabo, mas Petró continua o mesmo, e quanto mais tempo passa, mais sombrio ele se torna. Como se estivesse preso ao chão, fica sentado no meio da casa, os sacos com o ouro aos seus pés. Asselvajou-se, ficou peludo, feio, o tempo todo pensando na mesma coisa, se esforçando para lembrar alguma coisa, e fica com raiva e rancor por não conseguir. Muitas vezes se levanta ferozmente do seu lugar, agita os braços, crava seus olhos em algo como se quisesse apanhá-lo; os lábios se movem como se quisessem pronunciar alguma palavra há muito tempo esquecida - e param imóveis... A fúria o domina; como um demente, rói e morde suas mãos e, por despeito, arranca as madeixas do cabelo, até que, ao se aquietar, cai, como que em delírio, e depois de novo começa a lembrar, e de novo a fúria, e de novo o tormento... Que desgraça divina é esta? A vida se tornou insuportável para Pidorka. No começo, ela se sentia apavorada por ficar sozinha em casa, mas depois se acostumou com sua desgraça. Mas já não se podia reconhecer a Pidorka de antes. Nenhuma cor nas bochechas, nenhum risinho: desolada, debilitada, debulhara os olhos claros em lágrimas. Parece que uma vez alguém ficou com pena dela, deu-lhe o conselho para ir procurar uma feiticeira que morava em Medvéji Ovrag, que tinha a fama de curar todas as doenças do mundo. Decidiu recorrer a esse último recurso. Conversa vai, conversa vem, persuadiu a velha a segui-la. Foi à noite, precisamente

\footnotetext{
${ }^{677}$ Para se adivinhar a causa de sobressalto, jogavam um pedaço de estanho ou cera derretida na água; a coisa a que se assemelhar seria aquela que assustara o doente. Depois, todo o susto ia embora. Faziam um chá de sono contra náusea e dor de barriga. Para isso, queimavam fios de cânhamo, jogavam em uma caneca e a tornavam de cabeça para baixo numa tigela cheia de água, que era colocada na barriga do doente. Após as palavras mágicas sussurradas, davam-lhe para tomar uma colher dessa água. (Comentário de N.V. Gógol).
} 
na véspera do dia de Ivan Kupala. Petró, desmaiado, estava deitado num banco e nem percebeu a presença da visita. Mas, pouco a pouco, começou a levantar-se e a olhar para ela com atenção. De repente, tremeu como se estivesse no cadafalso; o cabelo ficou em pé... e ele riu de tal modo que o terror cortou o coração de Pidorka. "Lembrei, lembrei!" - gritou ele com uma alegria assustadora e, brandindo um machado, atirou-o com toda a força na velha. $\mathrm{O}$ machado cravou-se por duas polegadas na porta de carvalho. A velha desapareceu e uma criança de uns sete anos, com uma camiseta branca, com a cabeça coberta, surgiu no meio da casa... O lençol caiu. "Ivás!" - gritou Pidorka e se lançou em sua direção, mas o fantasma ficou ensanguentado dos pés à cabeça e iluminou a casa inteira com uma luz vermelha... Apavorada, ela correu para a entrada da casa. Ao recobrar os sentidos, queria ajudá-lo; em vão! A porta fechou-se bruscamente atrás dela com tanta força que ela não conseguiu abri-la. As pessoas se reuniram correndo; começaram a bater; quebraram a porta: não havia alma viva dentro. A casa inteira está cheia de fumaça, e apenas no meio, onde antes estivera Petró, há um monte de cinzas do qual, em alguns lugares, ainda subia um vapor. Atiraram-se aos sacos. Em vez de moedas, tinham somente cacos quebrados. Esbugalhando os olhos e boquiabertos, não ousando mover os bigodes, os cossacos ficaram parados como se estivessem pregados ao chão. Tanto foi o pavor instigado neles por esse feitiço.

O que aconteceu depois, não recordo. Pidorka fez a promessa de sair em peregrinação; juntou os bens herdados depois da morte do seu pai e, após alguns dias, sumiu como se nunca tivesse morado na aldeia. Para onde ela foi, ninguém sabia dizer. As velhas, com prontidão, mandaram-na para o mesmo lugar onde Petró fora arrastado; mas um cossaco que veio de Kiev contou que tinha visto, no monastério, uma monja, magra como um esqueleto, que rezava sem parar e na qual os conterrâneos, por todos os sinais, reconheceram Pidorka; disse que ninguém tinha ouvido palavra alguma dela; que ela chegara a pé e trouxera uma guarnição para ícones adornada com pedras tão brilhantes que todos semicerravam os olhos ao observá-la.

Esperem, este ainda não é o fim. No mesmo dia que o tinhoso carregou Petró, de novo surgiu Bassavriuk; mas todos correram dele. Perceberam agora que bicho é aquele: ninguém mais senão o Satanás, que assumiu a imagem humana para caçar tesouros escondidos; e como os tesouros não se entregam em mãos impuras, então ele atrai os jovens. No mesmo ano, todos largaram seus abrigos e se mudaram para uma aldeia nova; mas ali também o maldito Bassavriuk não deixava a gente em paz. A tia do falecido avô dizia que ele estava com a maior raiva exatamente dela, porque ela abandonara a taberna de antes, na estrada de 
Opochniá, e ele fazia todos os esforços para se vingar dela. Uma vez os anciãos da aldeia se juntaram na taberna e - como se diz - conversavam como se deve com os copos na mesa, no meio da qual foi posto, não seria mal dizer, um carneiro assado, não muito pequeno. Tagarelavam sobre isso e aquilo, sobre diferentes curiosidades e sobre milagres. Aí, pareceulhes, e não a um só, mas a todos, que o carneiro levantasse a cabeça, seu olhar vago se animasse e se iluminasse, e um bigode preto e hirsuto aparecesse repentinamente a todos os presentes e, num instante, começasse a se mexer com ar de importância. Todos, imediatamente, reconheceram na cabeça do carneiro a carranca de Bassavriuk; a tia do meu avô até esperava que já-já pediria vodca... Os anciãos honestos agarraram os chapéus e, a toda pressa, dirigiram-se para casa. Outra vez, o próprio curador da igreja, que, de quando em quando, gostava de ficar a sós com o cálice do seu avô, mal conseguiu atingir o fundo do copo umas duas vezes, quando viu que o cálice, em suas mãos, se curvava a ele. Diabo te carregue! Pôs-se a persignar-se!... E, ao mesmo tempo, sua amabilíssima esposa foi vítima de um feitiço: esta, mal começara a sovar a massa numa enorme bacia, quando, de súbito, a bacia saiu pulando para fora da mesa. "Para, para!" - tudo em vão! Endireitando-se com ar de importância, pôs-se a dançar a prisiádka pela casa inteira... Podem rir; mas nossos avôs não estavam rindo. Embora o padre Afanássi percorresse toda a aldeia com água benta e fizesse o diabo correr com o incensário pelas ruas, ainda por muito tempo a tia do falecido avô queixava-se de que alguém, logo quando chegava à noite, batia no telhado e arranhava a parede.

O que mais dizer! Aqui, neste mesmo lugar onde está nossa aldeia, ao que parece, tudo está calmo. Mas não muito tempo atrás, o meu falecido pai e eu ainda lembramos que uma boa alma não podia passar perto da taberna em ruínas, porque a tribo impura ainda a frequentou depois desse causo. Da chaminé enegrecida, a fumaça saía em volutas e, subindo tão alto que, se alguém olhasse, o chapéu caía; espalhava-se com as brasas quentes por toda a estepe, e o diabo (nem convêm lembrá-lo, filho de uma égua) soluçava com tanta força na sua casinha, que as gralhas, assustadas, levantavam-se em bando de carvalhos ao lado e, com um grito selvagem, iam desvairadas pelo céu. 


\title{
Uma noite de maio, ou a moça afogada
}

\begin{abstract}
O inimigo sabe! Se os cristãos começam a fazer algo, eles o perseguem penosamente, perseguem como os galgos perseguem a lebre, mas, apesar de tudo, algo está errado; onde o diabo se arrasta, ele abana o rabo - e de onde pode vir senão do céu ${ }^{678}$.
\end{abstract}

I

\section{Ganna}

Um canto canoro fluía como um rio pelas ruas da aldeia de ***. Era a hora em que, fatigados dos labores e preocupações do dia, rapazes e moças juntavam-se em algazarra numa roda, sob o brilho da noite clara, para derramarem suas alegrias em sons, ao mesmo tempo, repletos de angústia. E a noite, pensativa, sonhadora, abraçava o céu azul, tornando tudo vago e distante. Já desponta o crepúsculo; mas o canto ainda não cessa. Com uma bandurra nas mãos, o jovem cossaco Levkó - filho do cabeça da aldeia ${ }^{679}$ - que andava pé ante pé, esquivou-se dos cantores. O cossaco veste um gorro de Rechetílivka ${ }^{680}$ e, caminhando pela rua, dedilha as cordas e saltarilha. Finalmente, parou silencioso diante da porta de uma casa cercada por cerejeiras não muito altas. De quem será essa casa? De quem será essa porta? Guardou silêncio por alguns instantes, começou a tocar e a cantar:

O sol está baixinho, a noite está pertinho,

Saia para me ver, meu coraçãozinho! ${ }^{681}$

- Não, parece que minha beldade de olhos claros pegou no sono profundo! - disse o cossaco, que encerrou a cantoria e se aproximou da janela. - Gália ${ }^{682}$ ! Gália! Você está dormindo ou não quer sair para me ver? Provavelmente, você está com medo de que alguém vá nos ver, ou não quer, talvez, expor seu rostinho branco ao frio! Não tenha medo: não há ninguém. A noite está morna. Mas mesmo se alguém aparecer, eu te cobrirei com meu

\footnotetext{
${ }^{678}$ No original, em ucraniano.

${ }^{679}$ O cabeça (em russo: golová) é um cargo administrativo indicado pelos cossacos velhos da aldeia.

${ }^{680}$ Gorros de Rechetílivka (uma aldeia na região de Poltava, na Ucrânia central) são feitos de pele de cordeiro sob mesmo nome.

${ }^{681}$ No original, em ucraniano. O autor do texto é o poeta ucraniano Ivan Kotliarévski (1769-1838). Gógol usou vários versos deste poema no texto de Uma noite de maio, especialmente nos diálogos entre o protagonista Levkó e sua namorada.

${ }^{682}$ Um apelido para o nome Ganna.
} 
camisolão, te envolverei com meu cinto, te acolherei em meus braços - e ninguém nos verá. Mas mesmo se soprar o vento frio, te apertarei ao meu coração, te esquentarei com meus beijos, protegerei com o gorro suas perninhas brancas. Coração meu, meu peixinho, tesouro! Apareça, por um instante. Ao menos mostre na janela tua mãozinha branca... Não, você não está dormindo, moça arrogante! - disse ele mais alto, com uma entonação que expressava a vergonha de ter se humilhado de repente. - Você gosta de zombar de mim, adeus!

Com isso, ele se virou, enterrou o gorro na cabeça e, indignado, afastou-se da janela, dedilhando fracamente as cordas da bandurra. Nesse instante, a maçaneta de madeira começou a girar: a porta foi escancarada com um rangido, e uma moça, na sua décima sétima primavera, coberta pelo crepúsculo, olhando para trás com timidez e sem soltar a maçaneta de madeira, atravessou a soleira. Na semiescuridão, seus olhos claros cintilavam afavelmente, como estrelinhas; seu colar vermelho coralino brilhava e não podia nem mesmo esconder dos olhos aquilinos do rapaz o corado de timidez que flamejou em suas bochechas.

- Como você é impaciente, - disse-lhe à meia voz. - Já se zangou! Por que você foi escolher essa hora? Multidões vagueiam pelas ruas a todo o momento... Eu estou tremendo!

- Oh, não trema, minha amorinha vermelha! Encoste-se em mim com mais força! disse o rapaz, abraçando-a, enquanto se livrava da bandurra, que estava pendurada numa alça comprida no seu pescoço e sentou-se ao lado dela ao pé da porta da casa. - Você sabe que mesmo uma hora sem você é amarga para mim.

- Sabe em que eu estou pensando? - interrompeu-lhe a moça, fitando-o com seus olhos pensativos. - O tempo todo parece que um sussurro na minha orelha me diz que a partir de agora não nos veremos com tanta frequência. As pessoas daqui não são bondosas: as moças todas olham com tanta inveja e os rapazes... Eu até reparei que minha mãe recentemente começou a vigiar-me com mais severidade. Devo admitir que eu era mais alegre na casa dos forasteiros.

Um olhar de angústia manifestou-se em seu rosto com as últimas palavras.

- Apenas dois meses na terra natal e já cai em tristeza! Será que eu também te aborreci?

- Oh, você não me aborrece, - disse ela, sorrindo. - Eu te amo, meu cossaco de cabelos negros! Amo você porque tem olhos castanhos e, quando você me olha, parece que minha alma sorri; ela se sente tão alegre e feliz, porque alisa seu bigode negro com tanta graça; porque anda pelas ruas, cantarolando e tocando a bandurra, e eu adoro escutar você. 
- Oh, minha Gália! - gritou o rapaz, beijando-a e apertando-a com mais força junto ao peito.

- Para! Chega, Levkó. Antes diga, você conversou com seu pai?

- Sobre o quê? - disse ele, como se tivesse despertado de um sonho. - Que eu quero me casar com você, e você comigo? - conversei.

Mas, por alguma razão, essa palavra "conversei” ressoou tristemente na sua boca.

- E então?

- O que se pode fazer com ele? O velho caduco, como de costume, fez de conta que é surdo: não ouve nada e ainda me censura por estar vagueando sabe Deus onde, farreando e brincando com os rapazes pelas ruas. Mas não se aflija, minha Gália! Juro pela minha palavra de cossaco que conseguirei convencê-lo.

- Basta você dizer uma só palavra, Levkó, e tudo será como você quiser. Isso eu sei por mim mesma; às vezes, nem eu te obedeceria, mas você diz apenas uma palavra e, involuntária, faço o que você quer. Veja, veja! - continuava ela. Deitou sua cabeça no ombro dele e ergueu seus olhos para onde escurecia infinito o tépido céu ucraniano, encortinado pelos galhos frondosos das cerejeiras diante deles. - Veja, ali, ali, longe umas estrelinhas tremeluzem: uma, outra, a terceira, a quarta, a quinta... Será que são os anjos de Deus que abriram as janelas de suas casinhas luminosas no céu e estão olhando para nós? Sim, Levkó? São eles que olham para a nossa terra? Se as pessoas tivessem asas como os pássaros, que bom seria voar para lá, alto, alto... Ah, que medo! Nenhum carvalho daqui atingirá o céu. E dizem, apesar disso, que há, em algum lugar, em alguma terra distante, uma árvore cuja copa farfalha no céu, e que Deus desce a terra por ela na noite antes do dia santo.

- Não, Gália, Deus tem uma escada comprida que se estende do céu até a terra. Os santos arcanjos a colocam antes do Domingo Santo de Páscoa; e assim que Deus pisar no primeiro degrau, todos os espíritos impuros tombarão mediatamente e aos montes cairão no inferno, e, por isso, na festa do Cristo, não há nenhum espírito malvado na terra.

- Como a água está ondulando sem ruído, tal qual uma criança em seu berço! continuava Ganna, apontando para o lago sombrio, cercado por uma floresta escura de bordo $^{683}$ e pelos salgueiros chorosos ${ }^{684}$, que afogaram nele seus galhos lamentosos. Como um

\footnotetext{
${ }^{683}$ Bordo - um tipo de árvore comum na Ucrânia e na Rússia. No folclore eslavo, o bordo era considerado uma árvore mágica. Existiam crenças de que, com um feitiço malvado, uma pessoa poderia ser transformada num bordo; por isso, não se usava o bordo para a lenha ou como material para fabricação de caixão. Isto é especialmente importante porque o novo dono da casa abandonada quer construir uma destilaria no lugar da floresta; de certo modo, ele ofende os espíritos mágicos.

${ }^{684}$ Salgueiro - outro tipo de árvore comum na Ucrânia. Um dos epítetos constantes para esta árvore, na tradição eslava, é "chorosa" (em russo: plakútchaia), por causa dos seus galhos que pendem para a terra.
} 
fraco ancião, ele agarra com seus abraços frios o céu longínquo, escuro, cobrindo de beijos gélidos as estrelas ardentes que, opacas, deslizam no meio do morno ar noturno, como se estivessem pressentindo o surgimento próximo do esplêndido rei da noite. Ao lado do bosque, num morro, cochilava uma velha casa de madeira com contraventos fechados; o musgo e a erva daninha cobriam seu telhado; macieiras frondosas haviam crescido em abundância diante de suas janelas; o bosque, envolvendo-a com sua sombra, conferia-lhe um aspecto soturno e selvagem; um nogueiral estendia-se junto a sopé dele e descia ao lago.

- Lembro como se fosse num sonho, - disse Ganna, sem desviar seu olhar dele - há muito, muito tempo, quando eu ainda era pequena e morava na casa de minha mãe, contavam algo assustador sobre aquela casa. Levkó, você com certeza sabe, conte para mim!

- Deixe disso, minha beldade! O que não contarão as babas e o povinho estúpido. Você se inquietará, ficará com medo e não conseguirá dormir em paz.

- Conte, conte para mim, meu querido rapaz de cabelos negros! - disse ela, encostando o seu rosto na bochecha de Levkó, abraçando-o. - Não! Vejo que você não me ama, você deve ter outra namorada. Não ficarei com medo; dormirei em paz à noite. Agora é que não conseguirei dormir se você não me contar. Ficarei preocupada, pensando nisso... Conte, Levkó!

- Ao que parece, é verdade o que dizem as pessoas: dentro das moças há o diabo instigando sua curiosidade. Então escute. Há muito tempo, meu benzinho, naquela casa, morava um sótnik ${ }^{685}$. O sótnik tinha uma filha, uma bela pánnotchka ${ }^{686}$, bonita, branca como a neve, branca como o teu rosto. A mulher do sótnik já havia morrido há muito tempo; ele decidiu casar-se com outra. "Vai me mimar como antes, meu pai, quando casar com outra mulher?"- "Vou, minha filha; com ainda mais força vou te apertar ao meu coração! Vou, minha filha; brincos e colares ainda mais brilhantes dar-lhe-ei de presente!". O sótnik trouxe sua jovem esposa para a nova casa. Era formosa a jovem esposa. Era toda rosa e branca a jovem esposa; só que foi tão terrível o olhar que lançou para a enteada, que esta soltou um grito ao vê-la; e nem uma palavra lhe disse a severa madrasta durante o dia inteiro. Caiu a noite. O sótnik, com sua jovem esposa, foi para o seu aposento; a branca pánnotchka também se trancou em seu quarto. Sentiu muita amargura; começou a chorar. De repente, vê uma horrível gata preta se aproximando dela de mansinho; sua pele arde e as garras de ferro arranham o chão. Espantada, ela saltou num banco - a gata seguiu atrás dela. Atravessou num

\footnotetext{
${ }^{685}$ Sótnik - o chefe de centena administrativo-territorial ou militar na Ucrânia entre os séculos XVI e XVIII.

${ }^{686}$ Pan é uma palavra que se utiliza como forma de tratamento para a nobreza na Polônia e Ucrânia antigas (“senhor"). Pánnotchka refere-se a sua filha ("senhorita”).
} 
pulo para o leito - a gata também, e subitamente se atirou em seu pescoço, estrangulando-a. Arrancou-a de si com um grito, jogou-a no chão; de novo se aproxima a horrível gata. Foi tomada de pavor. Na parede, estava pendurado o sabre de seu pai. Agarrou-o e o atirou ao chão - uma pata com garras de ferro caiu e a gata, com um ganido, desapareceu num canto escuro. O dia inteiro a jovem esposa não saiu do seu quarto; no terceiro dia, saiu com uma mão enfaixada. A pobre pánnotchka adivinhou que sua madrasta era uma bruxa e que cortara uma mão. No quarto dia, o sótnik mandou sua filha carregar água, varrer a casa como se fosse uma simples camponesa, e lhe proibiu de aparecer nos aposentos do pan. Era penoso para a pobrezinha, mas ela não podia fazer nada: começou a cumprir a vontade do pai. No quinto dia, o sótnik expulsou sua filha descalça de casa e não lhe deu nem um pedaço de pão para levar. Apenas naquele momento, a pánnotchka chorou e escondeu seu rosto branco nas mãos: "Você deixou sua própria filha perecer, meu pai! A bruxa arruinou a sua alma pecadora! Que Deus te perdoe; quanto a mim, desgraçada, parece que Ele não permite mais que eu more neste mundo!" E ali, está vendo... ? - Neste momento, Levkó virou-se para Ganna, apontando seu dedo para a casa. - Olhe para lá; ali, um pouco mais longe da casa, fica a margem mais alta! Dessa margem, a pánnotchka atirou-se na água, e, desde aquele tempo, ela deixou este mundo...

- E a bruxa? - interrompeu Ganna amedrontada, fitando-o com os olhos cheios de lágrimas.

- A bruxa? As velhas inventaram que, desde aquela época, todas as moças afogadas saíam em noites luarentas no jardim do pan para se aquecerem na luz da lua crescente; e a filha do sótnik se tornou a chefe delas. Certa noite, ela viu sua madrasta ao lado do lago, atacou-a e com um grito, arrastou-a para a água. Mas a bruxa, mesmo assim, achou uma saída: transformou-se debaixo da água numa das moças afogadas e assim escapou de um açoite de cana verde com o qual as moças afogadas intentaram batê-la. Acredite na fala das babas! Contam também que toda noite a pánnotchka reúne as moças afogadas, uma a uma, e dá uma olhada em seus rostos, tentando adivinhar qual delas é a bruxa; mas até hoje não adivinhou. E se ela encontrar alguma pessoa viva, imediatamente, força-a a adivinhar, do contrário, ameaça afogá-la na água. Eis, minha Gália, o que contam os velhos! O pan de hoje quer construir uma destilaria naquele lugar e, de propósito, mandou pôr aqui um destilador... Mas eu estou ouvindo vozes. São os nossos colegas voltando da cantoria. Adeus, Gália! Durma em paz e não pense nessas invenções de babas!

Ao dizer isso, ele a abraçou com mais força, a beijou e foi embora. 
- Adeus, Levkó! - dizia Ganna, após fitar os olhos pensativos no bosque escuro.

Nesse momento, uma imensa lua ardente começou a se levantar da terra majestosa. Metade dela ainda estava sob a terra, mas o mundo inteiro já se enchera com uma luz solene. O lago cobriu-se de faíscas. A sombra das árvores começou a se distinguir claramente na grama verde-escura.

- Adeus, Ganna! - ressoaram as palavras atrás dela, seguidas por um beijo.

- Você voltou! - disse ela, olhando para trás. Mas ao ver diante dela um rapaz desconhecido, virou-se para o outro lado.

- Adeus, Ganna! - ouviu ela de novo, e de novo alguém beijou sua bochecha.

- O tinhoso trouxe mais um! - pronunciou com raiva.

- Adeus, querida Ganna!

- Ainda o terceiro!

- Adeus! Adeus! Adeus, Ganna! - e os beijos choveram nela de todos os lados.

- Aqui há uma corja inteira deles! - gritava Ganna, livrando-se de uma multidão de rapazes que se apressavam todos para abraçá-la ao mesmo tempo. - Como eles não se cansam de mandar beijinhos sem parar! Logo, juro por Deus, não será possível aparecer na rua!

Após essas palavras, a porta se fechou com força e só se ouviu, como um ganido, a tranca de ferro ser aferrolhada.

\section{O cabeça}

Vocês conhecem a noite ucraniana? Oh, vocês não conhecem a noite ucraniana! Observem-na com muita atenção. Do centro do céu, a lua olha para ela. A imensa abóbada celestial alarga-se e abre-se ainda mais imensa. Ela arde e respira. A terra inteira está repleta desse brilho prateado e o ar maravilhoso é refrescante e morno, cheio de volúpia, um oceano de aromas palpita. Uma noite divina! Uma noite encantadora! Os bosques erguem-se imóveis, misteriosos, cheios de escuridão e se lançam em sombras enormes. São quietos e tranquilos esses lagos; o frio e a escuridão de suas águas estão encarcerados, sombrios nas paredes verde-escuras dos jardins. Virgens brenhas de azereiras e cerejeiras estenderam com temor suas raízes no frio das águas e, de vez em quando, murmuram com suas folhas, como se estivessem bravas e indignadas com um formoso brincalhão frívolo - o vento noturno, 
aproximando-se sorrateiro para beijá-las. Toda a paisagem dorme. Mas, em cima, tudo respira, tudo é maravilhoso, tudo é solene. E a alma está plena de liberdade e maravilhada, e visões prateadas emergem, em harmonia, de suas profundezas. Uma noite divina! Uma noite encantadora! E, de repente, tudo se anima: os bosques, os lagos e as estepes. O majestoso canto do rouxinol ucraniano troveja, e parece que até a lua crescente parou no meio do céu para escutá-lo... Como encantada, a aldeia está cochilando nas alturas. Sob a luz da lua, as casas numerosas ficam ainda mais brancas, brilham ainda mais; e, ainda mais deslumbrantes, destacam-se das trevas suas paredes baixas. A cantoria se cala. Tudo está silencioso. As pessoas de Deus já estão dormindo. Apenas aqui e acolá há uma luz acesa nas janelas estreitas. Diante das soleiras de algumas poucas casas, famílias atrasadas estão comendo a sua refeição tardia.

- Não, não é assim que se dança a gopak ${ }^{687}$ ! É por isso que eu digo, nada tem jeito. E o que é isso que o meu colega está dizendo? Não ó: hop tralá! Hop tralá! Hop, hop, hop! Assim conversava consigo mesmo um mujique de meia idade, bêbado, dançando na rua. Juro por Deus, não é assim que se dança a gopak! Para que eu vou mentir? Juro por Deus que não é assim! Assim ó: hop tralá! Hop tralá! Hop, hop, hop!

- Olha só como o homem perdeu o juízo! Se fosse algum garoto, vá lá, mas é um velho javali e, para fazer as crianças rirem, fica dançando à noite na rua! - gritou uma mulher idosa que passava, carregando uma braçada de palha na mão. - Vá para sua casa! Já passou da hora de dormir!

- Eu vou!- disse o mujique e parou. - Eu vou. Eu não me importo com chefe nenhum. O que é que ele está pensando, que o diabo carregue o seu papai! ${ }^{688}$, que só porque ele é o chefe, ele pode derramar água gelada nas pessoas no inverno ${ }^{689}$, aí pode botar seu nariz para cima! Chefe, chefe o quê! Eu sou o meu próprio cabeça. É isso, que Deus me mate! Que Deus me mate, eu sou o meu próprio cabeça. É isso, e não é o que... - ele continuou, aproximandose da primeira casa que estava em seu caminho, e parou em frente a uma janela, escorregando seus dedos no vidro e tentando achar a maçaneta de madeira. "Baba, abra a porta! Baba, seja rápida, estou falando contigo, abra a porta! É hora do cossaco dormir!”

\footnotetext{
${ }^{687}$ Gopak - dança popular ucraniana, masculina. Inclui pulos, prisiádkas, viradas.

${ }^{688}$ No original, em ucraniano.

${ }^{689}$ Trata-se de um hábito comum nas aldeias ucranianas. Iúri Mann, no livro "Poética de Gógol” (MANN, 1978, p. 12), diz que uma ducha no frio era um castigo que os chefes nas aldeias da Maloróssia usavam para os camponeses que atrasavam os pagamentos. O mesmo detalhe está presente na peça cômica do teatro "Um simplório, ou a Astúcia da mulher, enganada por um soldado" do pai do escritor, Vassíli Gógol.
} 
- Aonde vai, Kalénik? Você está à porta da casa de outro! - gritaram atrás dele, rindo, algumas moças que estavam no caminho de volta da cantoria alegre. - Quer que mostremos a você a sua casa?

- Mostrem, jovens gentis!

- Jovens? Vocês ouviram - disse uma delas - como Kalénik é cortês! Por isso devemos mostrar a ele a sua casa... mas não, primeiro dance para nós!

- Dançar? Eh, vocês, moças engenhosas! - pronunciou Kalénik de modo prolongado, rindo, sacudindo o dedo e tropeçando, porque suas pernas não podiam se manter no mesmo lugar. - E vocês me deixarão beijá-las? Vou beijar vocês todas, todas! - e com passos oblíquos pôs-se a correr atrás delas.

As moças soltaram um grito e se dispersaram; mas depois, tomaram coragem e atravessaram correndo para o outro lado ao ver que Kalénik não tinha muita rapidez nos pés.

- Ali está a sua casa! - gritaram para ele, indo embora e indicando uma casa muito maior do que as outras, que pertencia ao chefe da aldeia. Kalénik caminhou obediente para aquela direção, pondo-se a censurar o chefe novamente.

Mas quem é esse chefe que suscitou boatos e falas tão desfavoráveis sobre si? Oh, esse cabeça é uma pessoa importante na aldeia. Enquanto Kalénik não atingir o fim de seu caminho, nós, sem dúvida, teremos tempo para dizer algo sobre ele. Toda a aldeia, ao vê-lo, tira os chapéus; e as moças, as mais jovens, lhe desejam um boa-tarde. Quem dos rapazes não gostaria de ser o chefe! O cabeça tem entrada franca em todas as tabaqueiras e o mujique robusto fica em pé respeitoso, com seu chapéu nas mãos, durante todo o tempo em que o cabeça mete seus dedos gordos e grossos na sua tabaqueira de entrecasca. Na reunião dos moradores, ou congregação ${ }^{690}$, apesar do fato de seu poder ser limitado a poucos votos, o chefe sempre toma as decisões e quase que por vontade própria manda quem ele quiser para nivelar e aplainar a estrada ou cavar os fossos. O chefe é sombrio, severo de aparência e não gosta de falar muito. Há muito, muito tempo, quando a grande tzarina Catarina de saudosa memória visitava a Criméia, ele foi escolhido como guia; executou esse cargo por dois dias inteiros e até teve a honra de sentar na boleia com o cocheiro da tzarina. Exatamente nesse tempo, o chefe aprendeu a inclinar sua cabeça para baixo com um ar de meditação e importância, cofiar seu bigode comprido, encaracolado e lançar de soslaio olhares de falcão. Desde esse tempo, também, o chefe, não se importa sobre o que falam com ele, sempre sabe puxar a conversa sobre como ele guiava a tzarina e sentava na boleia de sua carruagem. $\mathrm{O}$

\footnotetext{
${ }^{690}$ No original, em ucraniano.
} 
cabeça, às vezes, gosta de fazer de conta que é surdo, especialmente se ele escutar algo que não gostaria de ouvir. O chefe detesta janotismo: ele sempre usa um camisolão de feltro preto caseiro, amarra-se com um cinto colorido de lã, e ninguém jamais o viu em outra roupa, exceto, talvez, na ocasião da viagem da tzarina à Criméia, quando ele esteve vestido com um jupan $^{691}$ azul de cossaco. Mas é de se duvidar que alguém possa lembrar esse tempo em toda a aldeia e o jupan ele mantém num cofre trancado. O chefe é viúvo; mas, em sua casa, mora uma cunhada que prepara o almoço e o jantar, lava os bancos, branqueia a casa ${ }^{692}$, fia os tecidos para as suas camisas e cuida de toda a casa. Dizem na aldeia que ela nem é sua parenta, mas já vimos que há muitas pessoas mal intencionadas para com o chefe, prontos para espalhar uma calúnia qualquer. Por outro lado, talvez o fato de que a cunhada não gostava nada quando o chefe visitava um campo cheio de segadoras ou a casa de um cossaco que tinha uma filha jovem, deu motivo para isso. O cabeça é zarolho; mas,em compensação, seu olho solitário é um canalha e pode enxergar de longe uma colona bonitinha. Embora ele não o apontaria para um rosto bonitinho sem antes olhar bem ao seu redor para verificar se a cunhada não está espiando de algum lugar. Mas nós já contamos quase tudo o que é preciso sobre o chefe; e o bêbado Kalénik ainda não atingiu nem a metade do caminho e ainda alimentou por muito tempo o chefe com todos aqueles palavrões seletos que só poderiam sair de sua língua, que se movia com preguiça e incoerência.

\section{III.}

\section{Um rival inesperado. Conspiração.}

- Não, rapazes, não, não quero! Mas que pândega é essa! Vocês não se cansam de traquinar? Já basta a fama que nós ganhamos de sabe Deus que desordeiros. Melhor irem dormir! - Assim dizia Levkó aos seus companheiros pândegos que o instigavam a novas travessuras. - Adeus, irmãozinhos! Boa noite para vocês! - e se afastou deles, a passos rápidos, indo pela rua.

“Será que minha Ganna de olhos claros está dormindo?" - pensava ele, aproximandose da casa com cerejeiras já familiar a nós. Em meio ao silêncio, ouviu-se um murmúrio baixo. Levkó ficou parado. Entre as árvores, viu-se uma camisa branca... “O que significa

\footnotetext{
${ }^{691}$ Jupan - um tipo de vestimenta masculina ucraniana, espécie de camisa comprida.

${ }^{692} \mathrm{Na}$ Maloróssia do século XVIII e XIX, as pessoas costumavam morar em casas rebocadas - mázanki. Para cuidar dessas casas, os moradores deveriam cobrir suas paredes com argila e branqueá-las com cal. Antigamente eles faziam isso todo ano, antes da Páscoa.
} 
isso?" - pensou ele e, após aproximar-se, pé ante pé, escondeu-se atrás de uma árvore. Sob a luz da lua, brilhava o rosto de uma moça, parada diante dele... É Ganna! Mas quem é este homem alto que está de costas para Levkó? Em vão ele tentava observá-lo: uma sombra cobria-o dos pés à cabeça. Apenas na sua frente, caía-lhe um pouco de luz; mas um pequeno passo de Levkó à frente já o colocava no desagradável perigo de ser descoberto. Encostou-se quieto na árvore e decidiu permanecer no mesmo lugar. A moça pronunciou seu nome com clareza.

- Levkó? Levkó ainda é um fedelho! - dizia o homem alto a meia voz rouca. - Se eu o encontrar alguma vez em sua casa, eu vou arrancar-lhe o topete...

- Gostaria de saber quem é esse patife que se vangloria de arrancar meu topete! pronunciou Levkó em voz baixa e esticou o pescoço, esforçando-se para não perder nenhuma palavra. Mas o desconhecido continuava a falar em voz tão baixa, que não se podia distinguir nada.

- Você não tem vergonha! - disse Ganna no final do seu discurso. - Você está mentindo; você está me enganando; você não me ama; eu nunca vou acreditar que você me ama!

- Sei, continuava o homem alto, - Levkó te contou muitas bobagens e virou a sua cabeça (aqui pareceu ao rapaz que a voz do desconhecido lhe era um pouco familiar, como se ele a tivesse ouvido antes). Mas Levkó vai ver! - continuava o desconhecido do mesmo modo. - Ele acha que eu não vejo todos os seus namoricos. Ele vai experimentar, o filho de uma égua, como são os meus punhos.

Diante dessas palavras, Levkó não podia mais conter a sua raiva. Ao dar três passos em direção ao desconhecido, brandiu o punho com toda a força para dar-lhe um bofetão tamanho, que o desconhecido, apesar de sua aparente solidez, talvez não se aguentaria em pé; mas, nesse instante, a luz caiu em seu rosto e Levkó petrificou-se ao ver que diante dele estava o seu próprio pai. Somente com um balanço involuntário de cabeça e um assobio fraco entre os dentes, ele expressou sua surpresa. De um lado, ouviu-se um ruído. Ganna, com muita pressa, voou para dentro da casa e bateu a porta com um estrondo.

- Adeus, Ganna! - gritou neste momento um dos rapazes, que se aproximou do chefe e o abraçou, saltando para trás com terror ao dar de encontro com seu bigode áspero.

- Adeus, minha beldade! - gritou outro, mas esse saiu voando a toda pressa com o empurrão pesado do chefe.

- Adeus, adeus, Ganna! - gritaram vários rapazes e se penduraram no seu pescoço. 
- Vão para o inferno, seus diabretes malditos! - gritava o chefe, afastando-se deles com violência e batendo os pés. - Que diabo de Ganna eu sou? Vão embora, vão se enforcar ao lado dos seus pais, seus filhos do diabo! Colaram como as moscas no mel! Vou mostrar uma Ganna pra vocês!

- O chefe! O chefe! É o chefe! - gritaram os rapazes e se dispersaram por todos os lados.

- Oba, papai! - disse Levkó, voltando a si de seu espanto e olhando em direção ao chefe, que ia embora aos palavrões. - Assim são as travessuras de seu gosto! Ótimo! E eu me admiro e me pergunto o que deve significar isso, porque ele sempre finge ser surdo quando eu começo a falar sobre o negócio. Espere aí, seu velho caduco, vou te dar uma lição sobre como perambular debaixo das janelas das jovens moças, vou te dar uma lição sobre como conquistar as noivas dos outros! Hei rapazes! Venham cá, venham! - gritava ele, acenando para os rapazes, que novamente ajuntavam-se num grupo. - Venham cá! Eu vos exortava para irem dormir, mas agora mudei de ideia e estou pronto para farrear com vocês até uma noite inteira.

- Isso é outra coisa! - disse um rapaz espadaúdo e corpulento que tinha fama de primeiro farrista e pândego na aldeia. - Sempre me sinto entediado quando não consigo farrear com gosto e fazer bastante travessuras. É como se algo estivesse me faltando. Como se tivesse perdido um gorro ou um cachimbo; numa palavra, não me sinto cossaco e pronto.

- Vocês topam enfurecer bem o nosso chefe hoje?

$-\mathrm{O}$ chefe?

- Sim, o chefe. O que ele aprontou, realmente! Ele nos governa como um hetman. Não basta ele mandar em nós como se fossemos seus lacaios, ainda anda cortejando nossas moças. Pois eu acho que não há nenhuma moça bonita na aldeia para a qual o chefe já não tenha arrastado as asas.

- Pois é, pois é. - gritou todo o bando a uma só voz.

- Que raio de lacaios nós somos, rapazes? Não somos da mesma laia que ele? Somos, graças a Deus, cossacos livres! Vamos mostrar para ele, rapazes, que nós somos cossacos livres!

- Vamos! - gritaram os rapazes. - Mas se formos atrás do chefe, também não podemos deixar passar o escrivão!

- Também não vamos deixar passar o escrivão! E eu, como que por sorte, compus uma modinha boa sobre o chefe. Venham comigo, vou ensiná-la a vocês. - continuava Levkó, 
e em seguida atacou as cordas da bandurra com a mão. - E escutem só: fantasie cada um como bem quiser!

- Vai pandegar, a alma do cossaco! - disse o farrista alentado, bateu um pé contra o outro e bateu palmas. - Que maravilha! Que liberdade! Quando começa a fazer loucuras parece que está lembrando os velhos tempos. O coração fica alegre, livre, e a alma como que está no paraíso. Hei, rapazes! Hei, vamos pandegar!

E a multidão voou pelas ruas com muito barulho. E as velhinhas devotas, acordadas pelos gritos, abriram as janelas e se persignaram com as mãos frouxas, dizendo: "Aí, agora os rapazes estão em pândega!"

\section{IV.}

\section{Os rapazes em pândega}

Havia somente uma casa ainda iluminada ao final da rua. É a habitação do chefe. Faz tempo que o chefe acabou de jantar e, sem dúvida, faz tempo que ele gostaria de ir dormir. Mas naquela hora ele tinha uma visita, o destilador, mandado por um proprietário de terras, que tinha um pequeno terreno entre os cossacos livres para construir uma destilaria. Bem debaixo de um pokut ${ }^{693}$, no lugar de honra, a visita estava sentada - um homem baixinho, gordinho, com os olhos pequenos e sempre risonhos, nos quais parecia estar inscrito o prazer com que ele fumava seu cachimbo curto, a cada instante cuspindo e esmagando com seu dedo o tabaco que saia dele e que já havia se tornado cinzas. Nuvens de fumaça cresciam rapidamente por cima dele, cobrindo-o com uma neblina cinzenta. Tinha a aparência de uma ampla chaminé de alguma destilaria que, ao ficar entediada por se manter em seu telhado, decidira dar um passeio, e se pôr com muita cerimônia à mesa na casa do chefe. Debaixo do seu nariz, eriçava um bigode curto e basto, mas ele se divisava com tão pouca clareza em meio à atmosfera de tabaco, que mais parecia um rato que o destilador tinha capturado e guardava em sua boca, abalando o monopólio do gato que morava no celeiro. O chefe, como era o dono da casa, estava apenas de camisa e bombachas de linho. Seu olho aquilino, como um sol poente, pouco a pouco começava a se semicerrar e se apagar. Do outro lado da mesa,

\footnotetext{
${ }^{693}$ Pokut- um lugar de honra na casa reservado para os hóspedes importantes e onde também se encontram os ícones sagrados.
} 
um dos desiátski ${ }^{694}$ que fazia parte da equipe do chefe, vestido em camisolão, por respeito ao dono da casa, fumava um cachimbo.

- E quando, então, vocês pretendem, - disse o chefe, voltando-se para o destilador e fazendo o sinal da cruz por cima de sua boca bocejante - erguer a sua destilaria?

- Se Deus ajudar, nesse outono, talvez, começaremos a destilar. Na Festa do manto da Virgem $^{695}$, posso apostar que o pan vai andar pela estrada trançando as pernas.

Ao pronunciar essas palavras, os olhinhos do destilador sumiram de vista: em vez deles, esticaram-se uns raios até as suas orelhas; o corpo inteiro começou a tremer de riso, e os lábios alegres abandonaram por um instante o cachimbo fumegante.

- Queira Deus. - disse o chefe, e manifestou em seu rosto algo parecido a um sorriso. - Agora, graças a Deus, ainda surgiram muitas destilarias. Mas nos velhos tempos, quando eu guiava a tzarina pela estrada de Pereiaslav ${ }^{696}$ e o falecido Bezboródko ainda...

- Eba, compadre, que tempos você lembrou! Naquele tempo, de Krementchug até o próprio rio Romén, não havia nem duas destilarias. E agora... Você soube o que inventaram os malditos alemães? Dizem que daqui a pouco vão destilar não com lenha, como todos os cristãos honestos, mas com algum vapor diabólico. - Dizendo essas palavras, o destilador, em meditação, observava a mesa e seus braços deitados sobre ela. - Como assim, com vapor juro por Deus que não entendo!

- Que imbecis, Deus me perdoe, são esses alemães! - disse o chefe. - Eu os espancaria com um bastão, os filhos de uma égua! Onde já se viu uma coisa dessas, como que com vapor se pode ferver algo! Pois nem dá para aproximar uma colher de borsch da boca sem queimar os lábios, como se os lábios fossem um leitão novinho...

- E você, compadre, - manifestou-se a cunhada, sentada num leito com as pernas encolhidas - vai morar todo esse tempo em nossa casa sem sua esposa?

- E para que vou precisar dela? Se fosse algo bom, vá lá.

- Será que ela não é boa? - perguntou o chefe, após fitá-lo com um olho.

- De jeito nenhum! Tá velha como o mundo. A cara inteira coberta de rugas, que nem uma bolsa amarrotada. - E o corpo baixinho do destilador balançou-se novamente com um riso alto.

\footnotetext{
${ }^{694}$ Desiátski - um cargo menor, eleito pelos camponeses, normalmente de cada dez casas.

${ }^{695}$ Festa do manto da Virgem é uma das festas do calendário popular eslavo, comemorada dia 14 de outubro, e está conectada ao começo da preparação para o inverno.

${ }^{696}$ A estrada que se dirige à cidade de Pereiaslav que, na segunda metade do século XVI, era uma cidade regimental dos cossacos ucranianos.
} 
Neste momento, alguém começou a apalpar por detrás da porta; a porta se abriu de par em par e um mujique, sem tirar o chapéu, pisou na soleira e parou bem no meio da casa, boquiaberto e observando o teto, como se estivesse absorto em meditações. Era um conhecido nosso, Kalénik.

- Cheguei a casa! - disse ele e sentou-se num banco junto à porta sem prestar nenhuma atenção nas pessoas presentes. - Vixe, como esticou o caminho esse filho do inimigo, o Satanás! A gente anda, anda e não tem fim! Parece que alguém quebrou as minhas pernas. Pegue aí, baba, um casaco de pele, vou colocá-lo embaixo de mim. Não vou subir na petch' para deitar com você, juro por Deus que não vou: minhas pernas estão doendo! Pegueo, ele está aí, perto do pokut, mas fique de olho para não derrubar o pote com rapé moído. Ou melhor, não, não toque, não toque! Você deve estar bêbada hoje... Deixe, eu mesmo vou pegá-lo.

Kalénik levantou-se um pouco, mas uma força indomável pregou-o ao banco.

- Olha só que beleza, - disse o chefe, - entrou na casa de outro e está mandando e desmandando como se estivesse em sua própria casa! Botem-no para fora, por bem ou por mal!

- Deixa ele descansar um pouco, compadre! - disse o destilador, agarrando-lhe a mão. - Esse é um homem útil; se houvesse mais gente assim, a destilaria seria um sucesso...

Mas não foi a gentileza que provocou essas palavras. O destilador acreditava em toda sorte de crendices e, mandar embora imediatamente um homem que já havia se sentado no banco, significava, para ele, trazer azar.

- A velhice não é brincadeira - resmungava Kalénik, deitando-se no banco. - Quem dera eu estivesse bêbado; mas não, não estou. Juro por Deus que não estou! Para que vou mentir? Eu estou pronto para anunciar isso até ao próprio chefe. O que é o chefe para mim? Que ele estique as canelas, o filho de uma égua! Eu cuspo nele! Que aquele diabo zarolho seja atropelado por uma carroça! Acha que pode derramar água gelada nas pessoas, no inverno...

- Eba! Um porco enfiou-se em casa e ainda mete suas patas na mesa! - disse o chefe e levantou do seu lugar com raiva; mas, naquele momento, uma pedra pesada quebrou uma janela em mil pedaços e caiu debaixo dos seus pés. O chefe parou. - Se eu soubesse - disse ele, apanhando a pedra, - que canalha atirou isso, eu o ensinaria como atirar coisas! Que descaramento é esse! - continuava ele, observando a pedra em sua mão com um olhar ardente. - Que ele se engasgue com essa pedra... 
- Pare, pare! Deus te guarde, compadre! - reagiu, empalidecendo, o destilador. - Deus te guarde, nesse e no outro mundo, de benzer alguém com tamanho insulto!

- Agora virou seu defensor! Deixe que o diabo o carregue!

- Nem pense nisso, compadre! Você por acaso não sabe o que aconteceu com a minha falecida sogra?

- Com a sua sogra?

- Sim, com a sogra. À noite, talvez um pouco mais cedo que agora, nós nos pusemos à mesa para jantar: minha falecida sogra, o falecido sogro, também um criado e uma criada, e também as crianças - umas cinco. A sogra despejou um pouco de galuchkas de uma grande sopeira numa tigela para que não ficassem tão quentes. Depois do trabalho, todo mundo ficou com muita fome e não queriam esperar até que elas resfriassem. Ao espetar as galuchkas nos palitos cumpridos, começamos a comer. De repente, não se sabe de onde, surge um homem quem ele é, só Deus sabe, - pede permissão para comer também. Como não dar comida a um homem faminto! Demos também a ele um palito. Só que o hóspede devora as galuchkas que nem uma vaca o feno. E quando todos haviam comido apenas uma e abaixaram os palitos para pegar mais, o fundo da tigela já estava vazio como um poço seco. A sogra despejou mais galuchkas; pensava que o hóspede estava satisfeito e comeria menos. Nada disso. Começou a devorar ainda mais rapidamente! Esvaziou mais uma tigela! "Que você se engasgue com essas galuchkas!" - pensou a sogra faminta; e, de repente, ele se engasgou e caiu no chão. Lançamo-nos em socorro - mas ele já exalara o último suspiro. Asfixiara-se.

- Bem feito para ele, um glutão maldito! - disse o chefe.

- Seria, mas não deu nada certo. Desde aquele tempo, a sogra não tinha paz. Logo que começa a noite, o finado aparece arrastando-se. Monta na chaminé da casa, o maldito, e ainda guarda uma galuchka na boca. Durante o dia, tudo está calmo; mas, logo que começa a escurecer, é só olhar no telhado, e ali está ele, já subiu na chaminé, esse filho de uma égua.

- E ainda com uma galuchka na boca?

- E ainda com uma galuchka na boca.

- Que estranho, compadre! Ouvi algo parecido sobre a falecida tzarina...

Aqui o chefe parou. Debaixo da janela, ouviu-se um barulho e o bater de pés de pessoas dançando. Primeiro, ressoaram fracamente as cordas de uma bandurra, logo acompanhadas por uma voz cantando. As cordas trovejaram com mais força; várias vozes começaram a acompanhá-la e uma canção rumorejou como um turbilhão: 
Rapazes, ouviram o mesmo?

Nossas cabeças estão delirando?

O cabeça vesgo

Tem na cabeça um parafuso faltando.

Ponha, tanoeiro, no chefe

Os arcos de aço!

Borrife, tanoeiro, o chefe

Com um maço, com um maço!

Nosso chefe é grisalho e zarolho,

Velho como o diabo, que imbecil!

É caprichoso e luxurioso;

Chega nas moças sem alvoroço...

Imbecil, imbecil!

Não dá para competir com os moços!

Seria bom te dar um bofete,

Tirar seu bigode e acertar seu pescoço!

Arrancar seu topete! seu topete! ${ }^{697}$.

- Que musiquinha boa, compadre! - disse o destilador, inclinando sua cabeça um pouco de um lado e se virando na direção do cabeça, que ficara estupefato com tamanha insolência. - Boa! Só é uma pena que o chefe seja mencionado com palavras não muito decentes... - E de novo colocou suas mãos na mesa com alguma doce comoção em seus olhos, preparando-se para escutar mais, porque debaixo da janela trovejava uma risada e gritos: "De novo, de novo!". Mas uma pessoa sagaz logo perceberia que não era surpresa que detinha o chefe no mesmo lugar por tanto tempo. Assim, somente um gato velho e experiente deixa um rato inexperiente correr ao lado do seu rabo; e, enquanto isso, cria rapidamente um plano de como cortar caminho para a sua cova. O olho solitário do cabeça ainda estava cravado na janela e já a sua mão, que deu um sinal a um desiátski, agarrava a maçaneta de madeira da porta, quando, de repente, na rua levantou-se um grito... O destilador, que tinha entre os seus méritos também a curiosidade, encheu rapidamente seu cachimbo com o tabaco e saiu correndo para a rua, mas os traquinas já haviam se dispersado.

\footnotetext{
${ }^{697}$ Agradeço a Letícia Mei por sua ajuda com a versificação do poema gogoliano.
} 
“Não, não vai escapar de mim!" - gritava o chefe, puxando pela mão uma pessoa vestida num casaco de pele de cordeiro preto, virado ao avesso. O destilador, aproveitando o momento, se aproximou dele correndo, para dar uma olhada no rosto do perturbador da paz, mas recuou com cautela ao ver uma barba comprida e uma cara terrivelmente suja. "Não, não vai escapar de mim!" - gritava o chefe e continuava a arrastar seu prisioneiro pelo chão, direto para a entrada de casa, e aquele, não mostrando nenhuma resistência, seguia-o com calma, como se estivesse entrando em sua própria casa.

- Karpó, abra a despensa! - disse o chefe ao desiátski. - Vamos botá-lo na despensa escura! Aí vamos acordar o escrivão, juntar os desiátski, caçar todos esses desordeiros e ainda hoje dar início às punições para todos eles!

O desiátski tiniu um pequeno cadeado na entrada e abriu a despensa. Neste mesmo instante, o prisioneiro, aproveitando a escuridão da entrada, com uma força inesperada, subitamente livrou-se de suas mãos.

- Aonde vai! - gritou o chefe, agarrando-o pelo colarinho com ainda mais força.

- Solte, sou eu! - ouvia-se uma voz fininha.

- Não adianta! Não adianta, irmão! Pode ganir à vontade, não só como uma baba, mas até como o diabo, ninguém me fará de bobo! - e o empurrou para dentro da despensa escura com tanta força que o coitado do prisioneiro soltou uns gemidos, caindo no chão, e o próprio chefe, acompanhado pelo desiátski, dirigiu-se para a casa do escrivão, enquanto atrás deles, como um navio a vapor, seguiu fumegando o destilador.

Pensativos, os três andavam olhando para o chão, quando, repentinamente, ao virar para uma travessa escura, gritaram ao mesmo tempo devido a fortes golpes nas testas, e um grito igual troou em resposta a eles. O cabeça semicerrou seu olho e se surpreendeu ao ver o escrivão com dois desiátski.

- Estou indo para a sua casa, pan escrivão.

- E eu - para a casa de vossa mercê, pan chefe.

- Coisas do arco-da-velha, pan escrivão.

- Coisas estranhas mesmo, pan chefe.

$-\mathrm{O}$ que foi?

- Os rapazes estão fazendo diabruras! Estão criando desordem em bandos nas ruas. Alcunham vossa mercê com tantas palavras... Numa palavra, é uma vergonha de dizer; um moscal' bêbado não ousará pronunciá-las com sua língua ímpia. (Tudo isso o escrivão magrelo, em bombachas de linho e num colete da cor de fermento para vinho, acompanhava 
esticando o seu pescoço para frente e recolocando-o em seguida na posição de antes). Tirei um cochilo, mas os malditos diabretes me levantaram do leito com suas canções indecentes e batidas! Queria até pô-los na linha, mas, enquanto colocava as bombachas e o colete, todos se dispersaram,correndo para qualquer canto. O líder deles, porém, não nos escapou. Agora está cantando naquela casa onde se detêm os presos. Eu estava ardendo de curiosidade para saber quem era o tal bicho, mas a sua cara está toda suja de fuligem, como a do diabo que forja os pregos para os pecadores.

- E como ele está vestido, pan escrivão?

- O filho de uma égua veste um casaco de pele preto virado ao avesso, pan chefe.

- Não está mentindo, pan escrivão? E se esse mesmo diabrete está trancado agora na minha despensa?

- Não, pan chefe. Você mesmo, não me leve a mal, faltou um pouco com a verdade.

- Dê-me fogo! Nós vamos dar uma olhada nele!

Trouxeram o fogo, abriram a porta e o chefe exclamou com surpresa ao ver diante de si sua cunhada.

- Diga, por favor, - e com essas palavras ela se aproximou dele - você não perdeu seu último resquício de juízo ainda? Havia no seu crânio zarolho, pelo menos, uma gota de cérebro quando você me empurrou para dentro da despensa escura? Sorte minha que não dei com a cabeça no gancho de ferro. Não gritava para você que era eu? Agarrou-me, o urso maldito, com suas manoplas de ferro e ainda me empurrou! Que você seja empurrado no outro mundo pelos diabos!

Essas últimas palavras, ela levou consigo à rua, aonde se dirigiu para cuidar de alguns assuntos.

- Sim, estou vendo que é você! - disse o chefe após voltar a si. - O que você dirá disso, pan escrivão, não é um velhaco este maldito imprudente?

- Um velhaco, pan chefe.

- Não é hora de pôr na linha todos esses pândegos e os obrigar a trabalhar?

- Há muito tempo, há muito tempo, pan chefe.

- Aqueles imbecis meteram em suas cabeças... Mas que diabo é isso? Me pareceu um grito da cunhada na rua. Aqueles imbecis meteram em suas cabeças que sou igual a eles. Eles acham que eu sou algum irmão deles, um simples cossaco! - Após isso, uma pequena tosse e um olhar de soslaio ao seu redor deram a entender que o chefe se preparava para falar algo importante. - Em mil... não consigo pronunciar esses malditos números, nem que me matem; 
então, num ano, o então comissário Ledátchi recebeu a ordem de escolher entre os cossacos algum que fosse o mais sagaz de todos. Oh! - esse "oh!" o chefe pronunciou após levantar o dedo, - o mais sagaz de todos! Para ser guia para a tzarina. Então eu...

- O que mais dizer! Isso qualquer um já sabe, pan chefe. Todos sabem como você ganhou a mercê da tzarina. Agora deve confessar que eu tive razão; não faltou um tiquinho com a verdade ao dizer que prendera aquele diabrete em casaco de pele virado às avessas?

- Quanto a esse diabo no casaco de pele, para dar o exemplo aos outros, deve-se agrilhoá-lo e puni-lo exemplarmente. Deve-se mostrar para eles o que significa o poder! Quem nomeia o chefe senão o tzar? Depois pegaremos os outros rapazes: não me esqueci de como os malditos pândegos levaram para minha horta uma vara de porcos que devorou todo o meu repolho e os pepinos; não me esqueci de como os filhos do diabo recusaram-se a debulhar meus cereais; eu não me esqueci... Mas eles vão para o diabo, eu preciso saber sem falta quem é aquele velhaco no casaco de pele.

- Dá pra ver que o bicho é esperto! - disse o destilador, que durante toda essa conversa enchia as bochechas de fumaça, que nem um canhão de sítio, e os lábios, que soltaram o cachimbo curto, dispararam um jato inteiro de fogo. - Não seria má ideia prender um homem desses na destilaria; ou ainda melhor, enforcá-lo no cume de um carvalho, como se fosse um candelabro.

Essa piada não pareceu ao destilador completamente estúpida, e ele, em seguida, decidiu, sem esperar a aprovação dos outros, se servir de um riso rouco.

Neste momento, eles se aproximaram de uma casa não muito grande, quase ruída ao chão. A curiosidade dos nossos caminhantes aumentou. Todos se empilharam diante da porta. O escrivão pegou uma chave e a ribombou perto do cadeado, mas essa era a chave do seu cofre. A impaciência aumentou. Ele enfiou a mão no bolso, começou a vasculhar, soltando palavrões, sem achá-la. “Aqui!" - disse ele finalmente. Inclinou-se e a retirou do fundo do seu amplo bolso, com o qual eram guarnecidas suas bombachas de linho. Diante dessa palavra, os corações dos nossos heróis, ao que parece, uniram-se em um só e este enorme coração bateu com tanta força que sua batida desigual não podia ser abafada nem mesmo pelo som do cadeado tilintando. As portas se abriram, e... O chefe ficou pálido como um fantasma; o destilador sentiu um calafrio, e seu cabelo, ao que parece, quis voar para os céus; o horror se manifestou no rosto do escrivão; os desiátski ficaram pregados ao chão e não conseguiam fechar as suas bocas: diante deles estava a cunhada. 
Não menos pasmada do que eles, ela, porém, voltou a si em pouco tempo e fez um movimento para aproximar-se deles.

- Pare! - gritou o chefe numa voz selvagem e fechou bruscamente a porta diante dela. - Senhores! Isto é o Satanás! - continuou ele. - Dê-me fogo! Dê-me fogo depressa! Não pouparei nem a casa pública! Incendeie-a, incendeie, para que não sobre nem os ossos do diabo na terra!

A cunhada gritava aterrorizada, ouvindo por trás da porta uma ordem tão ameaçadora.

- O que é isso, irmãozinhos! - disse o destilador. - Graças a Deus, seus cabelos estão quase cobertos de neve, mas vocês ainda não aprenderam nada: a bruxa não vai se incendiar com um fogo simples! Apenas o fogo de um cachimbo pode incendiá-la. Peraí que eu vou arrumar tudo!

Ao dizer isso, ele esparramou as cinzas quentes do seu cachimbo numa braçada de palha e começou a soprá-las. Neste momento, o desespero tomou conta dos ânimos da coitada da cunhada, e, em voz alta, ela começou a implorar e tentar convencê-los a mudar de ideia.

- Esperem, irmãozinhos! Para que pecar em vão? Talvez nem seja o Satanás, - disse o escrivão. - Se aquilo, quer dizer, aquilo mesmo que está trancado ali, consentir em pôr um sinal da cruz em si mesmo, aí é um sinal indubitável de que não é o diabo.

A proposta foi aprovada.

- Xô, Satanás! - continuava o escrivão, encostando seus lábios na fechadura da porta. - Se você não se mover do lugar, abriremos a porta.

Abriram a porta.

- Persigne-se! - disse o chefe, olhando para trás, como se estivesse escolhendo um lugar seguro em caso de retirada.

A cunhada persignou-se.

- Que diabo! É realmente a cunhada!

- Que força impura te arrastou para cá, minha cara, neste buraco?

E a cunhada, soluçando, contou como os rapazes a pegaram em braçadas na rua e, apesar de sua resistência, a enfiaram pela janela larga da casa e pregaram a janela com tábuas. O escrivão deu uma olhada: os gonzos de um dos contraventos estavam arrancados e este estava pregado só por cima com uma barra de madeira.

- Muito bem, seu Satanás zarolho! - gritou ela e se aproximou do chefe, que retrocedeu um pouco e ainda continuava a examiná-la com seu olho. - Eu sei quais são suas intenções: você queria, você ficaria feliz de ter uma chance de me queimar para que pudesse 
cortejar as moças com mais liberdade, para que não tivesse ninguém vendo como o velho vovô anda fazendo bobagens. Você acha que eu não sei sobre o quê você conversou hoje à noite com Ganna? Oh! Eu sei de tudo. É difícil me enganar, e não seria por você, seu cabeça de vento. Tenho sido muito paciente, mas depois não vá se zangar...

Ao dizer isso, ela mostrou o punho em riste e partiu com pressa, deixando o chefe petrificado. "Não, aqui o Satanás se envolveu a sério", - pensava ele, coçando com força o seu cocuruto.

- Pegamos! - gritaram os desiátski, que entraram, neste momento, na casa.

- Pegaram quem? - perguntou o chefe.

- $\mathrm{O}$ diabo no casaco de pele às avessas.

- Entreguem-no! - gritou o chefe, agarrando as mãos do prisioneiro. - Vocês estão loucos: é o bêbado Kalénik!

- Mas que diabo! Ele estava em nossas mãos, pan chefe! - respondiam os desiátski. $\mathrm{Na}$ travessa, os malditos rapazes nos cercaram, começaram a dançar, a nos puxar, mostrar a língua, arrancá-lo das nossas mãos... o diabo a quatro!... E como nós acabamos com esse paspalho, só Deus sabe!

- Em meu nome e em nome de todos os colonos, vai uma ordem, - disse o chefe capturar, neste exato momento, o bandido e também todos aqueles que vocês acharem na rua, e conduzi-los até mim para punição!

- Tenha piedade, pan chefe! - gritaram alguns, curvando-se aos pés dele. - Se você visse as carrancas deles... que Deus nos mate, nascemos e fomos batizados - mas não vimos ainda caretas tão feias. Nunca se sabe o que pode acontecer, pan chefe, podem assustar tanto um homem de bem que depois nenhuma baba consentirá em aliviar o susto.

- Eu é que vou dar um susto em vocês! Que foi? Não querem me obedecer? Vocês devem ser amigos deles! Vocês são uns rebeldes! O que foi?... Sim, o que foi?... Vocês estão criando desordem!...Vocês... Vou denunciar ao comissário! Agora mesmo! Ouviram, agora mesmo! Corram, corram como o vento! Que eu... que vocês...

Todos correram para todos os lados.

V.

\section{A moça afogada}


Sem preocupar-se com nada, sem pensar em seus perseguidores, o responsável por todo esse rebuliço aproximava-se lentamente da velha casa e do lago. Suponho não ser necessário dizer que era Levkó. Seu casaco de pele preto estava desabotoado. O gorro, ele segurava numa mão. Escorria suor em bagas. A floresta de bordo, negra, se destacava de um modo majestoso e sombrio, encarando a luz da lua crescente. O lago imóvel soprou um vento fresco num passante cansado, obrigando-o a descansar à margem. Tudo estava silencioso. Do matagal, ouviam-se somente os trinos de um rouxinol. Um sono invencível começou a pregar os olhos de Levkó; o corpo, cansado, estava pronto para cair na modorra e se entorpecer; a cabeça inclinada... "Não, assim eu vou pegar no sono aqui!" - dizia ele, se levantando e esfregando os olhos. Olhou ao redor: a noite diante dele parecia ainda mais brilhante. Uma luz estranha, deleitosa se misturou com o resplendor da lua crescente. Nunca antes lhe ocorrera ver algo assim. Uma neblina prateada caiu sobre os arredores. $\mathrm{O}$ aroma das macieiras florescentes e das flores noturnas fluía por toda a terra. Pasmado, ele olhou para as águas imóveis do lago: a antiga casa senhorial, virada às avessas, era vista nele de um modo claro e com certo resplendor brilhante. No lugar dos contraventos soturnos, as janelas de vidro e as portas resplandeciam alegremente. Através das vidraças limpas, cintilava algo dourado. E, de repente, lhe pareceu que a janela se abrira. Retendo a respiração, sem contrair um só músculo e sem despregar os olhos do lago, ele, ao que parece, mergulhara em suas profundezas e viu: primeiro um cotovelo branco se debruçou na janela, depois apareceu uma cabeça pequena e gentil, com uns olhos cintilantes que irradiavam luz através das ondas dos cabelos castanhoescuros e se encostou no cotovelo. Viu que a moça balançava um pouco a cabeça, que acenava o braço, sorria... Num instante, o coração de Levkó começou a palpitar... A água ondeou e a janela se fechou de novo. Silencioso, ele se afastou do lago e olhou para a casa: os contraventos soturnos estavam abertos; as vidraças brilhavam sob a luz da lua crescente. "Veja só como se deve confiar nos rumores. - pensou ele. - A casa está novinha; as tintas estão tão frescas, como se ela tivesse sido pintada hoje. Alguém deve estar morando aqui". - e em se silêncio aproximou, mas tudo nela estava quieto. Canções de rouxinóis ecoavam umas nas outras de um modo vibrante e sonoro, e, quando pareciam morrer na ânsia e volúpia, ouvia-se o farfalhar e o cricrido dos grilos ou o estalido de uma ave do pântano, que batia com seu bico escorregadio no espelho amplo das águas. Levkó sentiu certa liberdade e um doce silêncio em seu coração. Afinando a bandurra, ele começou a tocar e a cantar:

Oi, lua, minha luazinha! 
E você, estrela clara!

Oi, iluminem o quintal

Em que mora a garota linda! ${ }^{698}$

A janela se abriu em silêncio, e aquela mesma cabeça, cujo reflexo ele vira no lago, espiou, escutando a música com atenção. Com seus longos cílios, ela semicerrava os olhos. Toda ela era branca como papel, como o brilho da lua crescente; mas como era admirável, como era bonita! Ela se pôs a rir... Levkó estremeceu.

- Cante para mim, jovem cossaco, cante alguma música! - disse ela em voz baixa, inclinou a cabeça de lado e baixou por completo seus cílios bastos.

- Que música você quer, minha querida pánnotchka?

As lágrimas escorreram silenciosamente pelo seu rosto pálido.

- Rapaz, - dizia ela, e algo inexplicavelmente comovente se ouviu na sua fala. Rapaz, ajude-me a encontrar a minha madrasta! Não lhe negarei nada. Eu te recompensarei. Recompensarei com presentes ricos e generosos! Tenho braceletes bordados em seda, colares, colarinhos. Dar-te-ei um cinto perolado. Tenho ouro também... Rapaz, ajude-me a encontrar a minha madrasta! Ela é uma bruxa terrível: por causa dela eu não tive paz neste mundo. Torturava-me, obrigava-me a trabalhar como uma simples camponesa. Olhe o meu rosto: ela tirou o corado das minhas bochechas com seus feitiços impuros. Veja meu pescoço branco: não saem! Não saem! Não sairão de jeito nenhum essas manchas azuis deixadas por suas garras de ferro! Olhe as minhas pernas brancas: elas andavam muito, não por tapetes, mas pela areia quente, pela terra fria, pelo abrunheiro bravo elas andavam; e os meus olhos, olhe para eles: não enxergam mais de tantas lágrimas... Procure-a, rapaz, procure minha madrasta!

Sua voz, que de repente se elevara, cessou. As lágrimas brotavam aos borbotões em seu rosto pálido. Um sentimento pesado, cheio de piedade e tristeza apertou o peito do rapaz.

- Estou pronto para fazer tudo por você, minha pánnotchka! - disse ele com emoção sincera - mas como, onde posso encontrá-la?

- Veja, veja! - disse ela rapidamente - Ela está aqui, brincando na margem numa roda entre as minhas donzelas e tomando banho de lua. Mas ela é esperta e ladina. Assumiu a aparência de uma moça afogada, mas eu sei, eu sinto que está aqui. Sinto um peso, uma falta de ar por causa dela. Por causa dela, não consigo nadar levemente, livre, como um peixe. Mergulho e caio no fundo, como uma chave. Procure-a, rapaz!

\footnotetext{
${ }^{698}$ Canção popular. No original, em ucraniano.
} 
Levkó observou a margem: na neblina fina e prateada passavam rapidamente, leves como sombras, moças em camisas brancas, como em um prado coberto de lírios do vale; seus colares de ouro, seus enfeites e ducados tremeluziam em seus pescoços, mas estavam pálidas; era como se seus corpos fossem esculpidos em nuvens transparentes e pareciam reluzir de um lado ao outro sob a luz da lua crescente prateada. A roda, brincando, se aproximou dele. Ouviram-se vozes.

- De corvo, vamos brincar de corvo! - rumorejaram todas como uma cana ribeirinha, tocada pelos lábios leves do vento na hora silenciosa do crepúsculo.

- Quem será o corvo, então?

Jogaram a sorte - e uma das moças saiu da multidão. Levkó começou a observá-la. O rosto, o vestido - tudo nela era tal qual nas outras. Via-se, somente, que ela desempenhava este papel a contragosto. A multidão se esticou numa fileira e corria de um lado ao outro, fugindo dos ataques do inimigo rapinador.

- Não, não quero ser o corvo! - disse a moça, abatida pelo cansaço. - Estou com pena de arrancar os pintinhos da sua pobre mãe!

"Você não é a bruxa!" - pensou Levkó.

- Quem será o corvo, então?

As moças se prepararam para jogar a sorte mais uma vez.

- Eu serei o corvo! - ofereceu-se uma delas.

Levkó começou a fixar seu olhar nela. Perseguia a fileira com velocidade e audácia, e se atirava para todos os lados, tentando capturar sua vítima. Neste momento, Levkó começou a perceber que seu corpo reluzia de um jeito diferente das outras: dentro dele se via algo negro. De repente, ressoou um grito: o corvo se atirou sobre uma das moças da fileira, agarrou-a, e pareceu a Levkó que suas garras se mostraram e, em seu rosto, fulgurou uma alegria maldosa.

- Bruxa! - disse, de súbito apontou para ela, e se voltou para a casa. A pánnotchka deu uma risada e as moças, com um grito, levaram consigo aquela que representava o corvo.

- Como agradecê-lo, rapaz? Eu sei, não é de ouro que você precisa: você ama Ganna, mas seu severo pai te impede de se casar com ela. Não vai te impedir mais; tome, dê-lhe esta carta...

A pequena mão branca se esticou, seu rosto reluziu e brilhou... Com um tremor incompreensível e um palpitar ansioso no coração, ele pegou a carta e... acordou. 


\section{VI.}

\section{O despertar}

Será possível que foi tudo um sonho? - disse Levkó para si, se erguendo de uma pequena colina. - Tudo parecia tão vivo, como se fosse real!... Estranho, estranho!... - repetiu ele, olhando ao seu redor. A lua crescente, parada em cima da sua cabeça, indicava a meianoite; em todo lugar reinava o silêncio; do lago, soprava um vento frio; acima dele, se encontrava a casa antiga com os contraventos fechados; o musgo e as ervas daninhas indicavam que os moradores a haviam abandonado há muito tempo. Neste momento, ele afrouxou seu punho, que estivera cerrado convulso durante o sono, e deu um grito de espanto, ao notar a carta na mão. "Ah, se eu soubesse ler!” - pensou ele, girando-a por todos os lados. Neste instante, ouviu-se um barulho atrás dele.

- Não tenham medo, peguem-no de jeito! Por que ficaram assustados? Somos dez. Posso apostar que esse aí é gente e não o diabo! - assim gritava o chefe aos seus companheiros, quando Levkó se sentiu agarrado por várias mãos, algumas das quais tremiam de medo. - Amigo, tire sua máscara assustadora! Chega de fazer as pessoas de tolas! pronunciou o chefe, agarrou-o pelo colarinho, e, perplexo, esbugalhou seu olho. - Levkó, meu filho! - gritou, se afastando, surpreso, e baixando as mãos. - Era você, seu filho de uma égua! Ah, sua criatura do diabo! Eu tentando adivinhar quem é o tal patife, e que diabo seria esse casaco virado às avessas, pregando peças! E então acaba que é tudo coisa sua, tomara que seu pai se engasgue, mas que atrevimento, sair aí conduzindo toda essa balbúrdia e compondo canções!... E-he-he, Levkó! O que significa isso? Ao que parece, suas costas estão pedindo uma chicotada! Amarrem-no!

- Espere, pai! Mandaram-me entregar-lhe esta carta, - disse Levkó.

- Não há tempo para cartas agora, meu caro! Amarrem-no!

- Espere, pan chefe! - disse o escrivão ao desdobrar a carta - é a letra do comissário!

- Do comissário?

- Do comissário? - repetiram os desiátski maquinalmente.

“Do comissário? Que estranho, ainda mais enigmático!”- pensou Levkó.

- Leia, leia! - disse o chefe - O que o comissário escreve?

- Vamos escutar o que escreve o comissário! - pronunciou o destilador, segurando o cachimbo pela boca e acendendo o fogo. 
O escrivão pigarreou e começou a ler:

- "Ordem ao chefe da aldeia, Evtukh Makogónenko. Chegou ao nosso conhecimento que você, um velho tolo, em vez de coletar os pagamentos atrasados e pôr a aldeia em ordem, ficou besta e trama intrigas..."

- Juro por Deus - interrompeu o chefe - que não ouvi nada!

O escrivão começou de novo:

- "Ordem ao chefe da aldeia, Evtukh Makogónenko. Chegou ao nosso conhecimento que você, um velho to..."

- Pare, pare! Não precisa! - gritou o chefe - Apesar de eu não ter ouvido entendi já que esse não é o assunto principal. Prossiga a leitura!

- Em consequência disso, ordeno-lhe casar imediatamente seu filho Levkó Makogónenko com a cossaca da sua aldeia, Ganna Petrytchénkova, e, além disso, consertar as pontes na estrada central e também não dar os cavalos dos colonos aos pans do tribunal sem meu consentimento, mesmo que eles estejam vindo diretamente da câmara do Estado. Caso, quando chegar, encontre alguma ordem minha não executada, apenas você será o único responsável. Comissário, tenente retirado, Kozmá Derkatch-Drichpanóvski”.

- Vejam só! - disse o chefe, boquiaberto. - Vocês estão ouvindo, estão ouvindo? O chefe vai responder por tudo, por isso devem obedecer! Obedecer sem objeção! Do contrário, não reclamem... E quanto a você, - continuava ele, voltando-se para Levkó - devido à ordem do comissário, embora me pareça estranho como foi que isso chegou até ele, caso você, mas primeiro vai experimentar uma chicotada! Sabe aquele chicote que está pendurado em casa na parede ao lado do pokut? Vou consertá-lo amanhã... De onde você tirou esta carta?

Levkó, apesar do assombro que lhe causara a inesperada reviravolta das coisas, tinha a prudência de ter em mente outra resposta para esconder a verdade sobre como lhe caíra nas mãos a carta.

- Eu me dirigia - disse ele - ainda ontem à noite para a cidade e encontrei o comissário, que saía da brisca ${ }^{699}$. Ao descobrir que sou da nossa aldeia, deu-me esta carta e ainda me ordenou que lhe transmitisse pessoalmente, papai, que no caminho de volta passará aqui e almoçará conosco.

- Ele disse isso?

- Disse.

\footnotetext{
${ }^{699}$ Brisca - carro leve transformado em trenó, usado na Rússia do século XIX.
} 
- Vocês ouviram? - disse o chefe, voltando-se para seus companheiros com ares de importância - o comissário vem nos visitar pessoalmente, quer dizer, me visitar, no almoço! Oh! - Aqui o chefe levantou o dedo e pôs a cabeça em tal posição, como se estivesse apurando alguma coisa. - O comissário, vocês ouviram, o comissário vem almoçar em minha casa! O que você acha, pan escrivão, e você, compadre, isto não é qualquer coisa! Não é?

- Pelo que eu me lembro - adicionou o escrivão - nenhum chefe ofereceu almoço ao comissário.

- Nem todos os chefes são iguais! - proferiu o chefe, cheio de si. Sua boca se entortou, e um riso pesado e rouco, mais parecido com o ruído de um trovão distante, ressoou de seus lábios. - O que você acha, pan escrivão, para uma visita ilustre, é preciso ordenar que de cada casa traga um frango ou um tecido, ou alguma outra coisa... Não é?

- É preciso, é preciso, pan chefe!

- E o casamento, papai? - perguntou Levkó.

- O casamento? Mostrarei um casamento para você!... Mas, em honra da visita ilustre... o pope casará vocês amanhã. Vão ao diabo! Que o comissário veja o que significa a diligência! E agora, amigos, vamos dormir! Vão para as suas casas!... Os acontecimentos de hoje me lembraram daquele tempo em que eu... - Com essas palavras, o chefe lançou de soslaio seu olhar usual, importante e significativo.

- Agora o chefe começará a contar como ele guiava a tzarina! - disse Levkó e, com passos rápidos, se apressou alegre até a casa familiar a nós, cercada pelas cerejeiras baixas. "Que Deus a tenha, bondosa e maravilhosa, pánnotchka - pensou ele. - Que você esteja sempre sorrindo entre os santos anjos! Não contarei para ninguém o milagre que aconteceu nesta noite, apenas para você, Gália, vou segredá-lo. Você será a única que acreditará em mim e rezará comigo pela alma da infeliz moça afogada!"

Neste momento, ele se aproximou da casa. A janela estava aberta; os raios da lua crescente atravessavam-na e caíam sobre Ganna, que dormia diante dela; sua cabeça estava apoiada nas mãos; as bochechas ardiam levemente; os lábios se moveram, pronunciando vagamente o nome de Levkó. "Durma, minha beldade! Que você sonhe com tudo o que há de melhor no mundo, mas até isso não será melhor que o nosso despertar!”. Tendo se persignado sobre ela, ele fechou a janela e se retirou silenciosamente. E, após alguns minutos, todos na aldeia já haviam adormecido; somente a lua crescente continuava pairando brilhante e maravilhosa nos desertos imensos do esplêndido céu ucraniano. Solene, ele continuava respirando nas alturas, e a noite, a noite divina, ardia majestosa. A terra continuava linda em 
seu brilho maravilhoso e prateado, mas já ninguém se inebriava com isso: todos caíram no sono. Apenas de vez em quando o silêncio era interrompido pelo latido dos cachorros, e ainda por muito tempo o bêbado Kalénik cambaleou pelas ruas adormecidas, à procura de sua casa. 


\title{
Referências Bibliográficas
}

\author{
Obras de N.V. Gógol
}

GÓGOL, N.V. A Avenida Niévski. Trad. Arlete Cavaliere e Mário Francisco. São Paulo: Paz e Terra, 2002.

_. A feira anual de Sorotchinski. Trad. de Tatiana Belinky. São Paulo, Ática, 1995. . Almas Mortas. Trad. de Tatiana Belinky. São Paulo, Abril Cultural, 1979. Kniga vsiákoi vsiátchiny, ili podrútchnaia èntsiklopédiia (Livro de todas as coisas variadas, ou uma enciclopédia auxiliar). In . Pólnoe sobránie sotchinénii v 14 tomakh (Obra completa em 14 tomos). Moskvá-Leningrad: 1937-1952. Tomo 9.

. Ob arkhitekture nynechnego vrémeni (Sobre a arquitetura de hoje). In

Pólnoe sobránie sotchinenii v 14 tomakh (Obra completa em 14 tomos). Tomo 8. Artigos. Moskvá - Leningrad: AN SSSR, 1952.

O capote e outras histórias. Tradução, posfácio e notas de Paulo Bezerra. São Paulo: Editora 34, 2010.

. O nariz e A Terrivel Vingança. Trad. de Arlete Cavaliere. São Paulo: Editora da Universidade de São Paulo, 1990.

. O srédhikh vekakh (Sobre a Idade Média). In Pólnoe sobránie sotchinenii v 14 tomakh (Obra completa em 14 tomos). Tomo 8. Artigos. Moskvá - Leningrad: AN SSSR, 1952.

. Pólnoe sobránie sotchinéni v 14 tomakh (Obra completa em 14 tomos). Tomo 10.

Cartas, 1820-1835. In MECHTCHERIAKOV N. K. (org.). Moskvá-Leningrad: AN SSSR, 1940 ,

. Sobránie sotchinéni v semí tomakh (Obras em 7 tomos). In

MACHÍNSKI S. I, KHRÁPTCHENKO M. B. (org.). Tomo I. Moskvá: Khudójestvennaia literatura, 1976.

Teatro completo. Organização, tradução, prefácio e notas de Arlete Cavaliere. São Paulo: Ed. 34, 2009.

The complete tales of Nikolai Gogol. Edited, with an introduction and notes, by Leonard J. Kent. Trad. de Constance Garnett. Chicago-London, The University of Chicago press, 1985. Vol. I. 


\section{Bibliografia sobre Gógol, teoria e crítica literária em português}

CESERANI, Remo. O fantástico. Trad. de Nilton Cezar Tridapali. Curitiba: UFPR, 2006. CAVALIERE, Arlete. A magia das máscaras. In GÓGOL, Nikolai. O nariz e A Terrível Vingança. Trad. de Arlete Cavaliere. São Paulo: Editora da Universidade de São Paulo, 1990. Teatro russo: percurso para um estudo da paródia e do grotesco. São Paulo:

Humanitas, 2009.

GOMBRICH, E.H. A História da Arte. 15a edição. Tradução de Álvaro Cabral. Rio de Janeiro: Editora Guanabara Koogan, 1993.

JOLLES, André. Formas simples: Legenda, Saga, Mito, Adivinha, Ditado, Caso, Memorável, Conto, Chiste. Trad. Álvaro Cabral. São Paulo: Ed. Cultrix, 1976.

JAUSS, Hans Robert. A história da literatura como provocação à teoria literária. Trad. de Sérgio Tellaroli. São Paulo: Ática, 1994.

PETROVA, Maria. As bruxas na obra de Nikolai Gógol: Uma evolução da imagem folclórica. In Anais do VII Simpóio Nacional da História Cultural - Escrita, circulação, leituras e recepções. São Paulo: 2015.

Proximidade dos contos ucranianos de Nikolai Gógol ao conto maravilhoso. In VIII Encontro de Letras Orientais e Eslavas, 2013, Rio de Janeiro. Caderno de Programação e Resumos do VIII Encontro de Letras Orientais e Eslavas, 2013.

PHILIPPOV, Renata. Sonhos e fantástico em Edgar Allan Poe e Charles Baudelaire. 1999. Tese (mestrado em letras). Universidade de São Paulo, 1999.

PROPP, Vladímir. As raízes históricas do conto maravilhoso. Trad. de Paulo Bezerra. São Paulo: Martins Fontes, 1997. Morfologia do conto maravilhoso. Rio de Janeiro: Forense-Universitária, 1984.

PUSHKIN, Aleksandr. Eugênio Oneguin. Romance em versos. Moscou: Grupo Editorial "Azbooka - Atticus", 2008.

VERNANT, Jean-Pierre. Mito e pensamento entre os gregos. Estudos de psicologia histórica. Trad. De Haiganuch Sarian. Rio de Janeiro: Paz e Terra, 1990.

\section{Bibliografia sobre Gógol, teoria e crítica literária em russo}

AFANÁS'EV, A.K. Poètítcheskie vozzréniia slavián na prirodu (As ideias poéticas dos eslavos sobre a natureza). Em três tomos. Tomo III. Moskvá: Sovrieménnyi pisátel', 1995. 
ALEKSÁNDROVSKI G.V. Istóriko-literatúrnye kommentárii $k$ povestiám N.V. Gógolia "Vietcherá na khútore bliz Dikanki" (Os comentários histórico-literários às novelas de N. V. Gógol 'Noites em uma granja perto de Dikanka'). Kiev: tipografia de P.I. Bonadúrer, editor F.A. Ioganson, 1914.

ALEKSÉEV, M. P. Tch. P. Mét'iurin i evo "Mel'mot skitálets" (C. Maturin e o seu 'Melmoth ou homem errante'). Moskvá: Naúka, 1983. Disponível: <http://thelib.ru/books/alekseev_m/chrmetyurin_i_ego_melmot_skitalec-read.html>. ALLÉNOVA, Tatiana. Kategóriia irreálnovo ujássnovo $i$ spóssoby eió vyrajéniia v khudójestvennom prostránstve N.V. Gógolia na materiale yazyká povestéi "Vetcherá na khútore bliz Dikanki" $i$ "Mírgorod" (A categoria do irreal terrivel e os modos de sua manifestação no espaço artístico de N. V. Gógol no material da linguagem das novelas de 'Noites emu ma granja perto de Dikanka' e 'Mírgorod'). Tese (Doutorado em filologia). Moskvá: Universidade estatal de Moscou de pedagogia (MPGU), 2000.

ARKHÍPOVA, I. V. Khudójestvennoe soznánie N.V. Gógolia i estètika barokko (A consciência artística de N. V. Gógol e a estética do barroco). Dissertação do doutorado em filologia. Ekaterinburg, 2004.

BAKHTIN, M. M. Rablé i Gógol' (Rabelais e Gógol). In Tvórtchestvo Fransuá Rablé e naródnaia kultura srednevekóvia e Renessansa (A cultura popular na Idade Média e no Renascimento: o contexto de François Rabelais). Moskvá: Khudójestvennaia literatura, 1965.

Vopróssy literatury i estétiki: Isslédovaniia ráznykh let (As questões de literatura e estética: As pesquisas dos anos variados). Moskvá: Khudójestvennaia literatura, 1975. Sobranie sotchinénii (Obras). Volume 3. Teóriia romana (1930-1961) (A teoria do romance). Moskvá: Iazykí slaviánskikh kul'tur, 2012.

BARABACH, I. Chotlandsko-irlándskie paralleli v gogolevédenii ukraínskovo zarubéj 'ia (Os paralelos escocês-irlandeses nas pesquisas sobre Gógol dos ucranianos no exterior). In MANN (org.), 2003.

.Gógol' i traditsii staroukraínskovo teatra (Dva etiúda) (Gógol e as tradições do teatro antigo ucraniano). In VIKÚLOVA, V. P. (Org.) N. V. Gógol' i teatr: III gógolevskie tchténiia (N. V. Gógol e o teatro: as III leituras gogolianas). Moskvá: Knijnyi dom "Universitet", 2004.

BOTCHAROV, Sergei. “Krassávitsa mira”. Jénskaia krassota u Gógolia (A beldade do mundo. A beleza feminina em Gógol). In MANN (Org.), 2003. 
BÉLYI, Andrei. Gógol' (Gógol). In GONTCHAROV, S. (Org.) Gógol': Pro et Contra. Tomo I. Sankt-Peterburg: Rússkaia khristiánskaia gumanitárnaia akadémia, 2009. Masterstvó Gógolia: Isslédovanie (Mestria de Gógol. Uma pesquisa). Prefácio de

L. Kámenev. Moskvá-Leningrad: Gosudárstvennoie izdátelstvo khudójestvennoi literatury, 1934.

Simvolizm kak miroponimánie (O simbolismo como a compreensão do mundo). Moskvá: Respúblika, 1994.

BLAGÓI, D. Motiv (O motivo). In BRÓDSKI, N., LAVRÉTSKI, A. LÚNIN, È. et al. (Org.) Literatúrnaia èntsiklopédiia. Slovar' literatúrnykh términov (Enciclopédia literária.

Dicionário dos termos literários). Em 2 tomos. Moskvá, Leningrad: Izdátel'stvo Frénkel', 1925. Tomo 1

BRIÚSSOV, Valérii. Ispepeliónnyi. K kharakterístike Gógolia (Incinerado. Para uma característica de Gógol). In GONTCHAROV (Org.), 2009.

BUTÚZOV, A.E. (Org.) Rússkaia gotítcheskaia póvest' XIX veka (A novela gótica russa do século XIX). Moskvá: Tri kvadrata, 2008.

CHAMBINAGO, S. K. Gógol’ i Goia (Gógol e Goia). In GONTCHAROV (Org.), 2009.

DE LOTTO, CINZIA. Gógol': odéjda i moda (Gógol: a roupa e a moda). In MANN (Org.), 2003.

DAL', V. I. Tolkóvyi slovar' jivovo velikorússkovo iazyká (Dicionário da língua russa viva). Em 4 tomos. Moskvá: Drofá, 2011.

DMÍTRIEVA, Ekaterina. N.V. Gógol'v zapadnoevropéiskom kontekste: méjdu iazykami i kul'túrami (Gógol no contexto da Europa Ocidental: entre as línguas e as culturas). Moskvá: IMLI RAN, 2011.

EIKHENBAUM, Boris. O proze. O poèzii. Sbornik statéi (Sobre a prosa. Sobre a poesia. Uma coletânea de artigos). Leningrad: Khudójestvennaia literatura, 1986.

FIÓDOROV, F. P. (Org.) Rússkii romantizm: prostranstvo e vriémia (O Romantismo russo: o espaço e o tempo). Dáugavpils: Izdátelstvo Daugavpíllskovo pedagogítcheskovo universiteta, 1991.

GÍPPIUS, V.V. Gógol’ (Gógol). In GONTCHAROV, S. A (Org.), 2009.

GIÚNTER, Hans. Méjdu mamónoi i místikoi. Problemátika hudójnika v 'Portrete' Gógolia (Entre Mamon e a mística. A problemática do artista em 'O Retrato' de Gógol). In MANN (Org.), 2003 
GONTCHAROV, S.A. (Org.) Gógol': Pro et Contra. Tomo I. Sankt-Peterburg, Rússkaia khristiánskaia gumanitárnaia akadémia, 2009.

(Org.) Gógolevski sbórnik (A coletânea de Gógol). Sankt-Peterburg, Obrazovánie, 1993.

Son - duchá, liubov' - sem 'iá, mujskóe - jénskoe v ránnem tvórtchestve Gógolia

(Sonho-alma, amor-família, masculino-feminino na obra de Gógol jovem). In (Org.), 1993.

GORODÉTSKI, B. P., PRUTSKOV, N. I, FRIDLÉNDER, G. M. (Org.). Rússkaia literatura. Trudy otdéla nóvoi rússkoi literatury (A literatura russa. Os estudos do departamento da literatura russa nova). Tomo I. Moskvá-Leningrad: AN SSSR, 1957.

GRÉKOV, Vladímir. "Poslédni den'Pompéi” glazami N.V. Gógolia i V.F. Odóevskovo: ot razruchéniia "idillii” $k$ razruchéniiu kósmossa ('O último dia de Pompeia' através do olhar de Gógol e de Odóevski: da destruição de um 'idílio’ à destruição de cosmos). In MANN (Org.), 2003.

GUKÓVSKI, G. A. Realizm Gógolia (O realismo de Gógol). Moskvá-Leningrad:

Gosudárstvennoe izdátel'stvo khudójesvennoi literatury, 1959.

GURÉVITCH, A. I. Kategórii srednevekóvoi kultury (As categorias da cultura da Idade Média). Moskvá: Iskusstvo, 1972.

GURÉVITCH, Pável. Rol'óbrazov plastitcheskikh iskusstv v khudójestvennom mire Gógolia na materiale khudójestvennoi prozy (O papel das imagens das artes plásticas no mundo artístico de Gógol, no material da prosa). In MANN (Org.), 2003.

IASIUKÓVITCH, I. V. Muzykál'nye obrazy v rússkoi romantitcheskoi proze 30-40kh godov XIX veka (As imagens musicais na prosa russa romântica dos anos 30-40 do século XIX). Kolómna: Kolómenski gosudárstvennyi pedagogítcheski institut, 2003.

IVANÍTSKI, Aleksandr. Gógol' I Gofman: istok i preodolénie groteska (Gógol e Hoffmann: a fonte e a superação do grotesco). In MANN (Org.), 2003.

JIRMÚNSKII, V.M. Teóriia literatury. Poètika. Stilístika (Teoria literária. Poética. Estilística). Leningrad: Naúka, 1977.

KALÁCHNIKOVA, O.L. Gógol' i “drugóe” barokko: tol’ko li "profetítcheski páfos"? (Gógol e o 'outro’ barroco: apenas o 'ênfase profético'?) In VIKÚLOVA, V.P. (Org.) N.V. Gógol'i sovreménnaia kul'tura: 6-e gogolévskie thcténiia. Moskvá: KDU, 2007.

KAPITÁNOVA, L. A., KORÓVIN, V.I. et. al. Proza v èpókhu romantizma (A prosa na época do romantismo). In KORÓVIN, V.I. (Org.). Istóriia rússkoi literatury XIX veka: v 3 
tchastiákh (A história da literatura russa do século XIX. Em três partes). Parte 2. Moskvá: Vládos, 2005.

KARANDACHOVA, Ol'ga. Khudójestvennoie prostranstvo “ukrainskikh” sbornikov N.V. Gógolia ("Vetcherá na khútore bliz Dikanki”, "Mírgorod”) (O espaço artístico das coletâneas ucranianas de N. V. Gógol ('Noites em uma granja perto de Dikanka', 'Mírgorod'). Tese (doutorado em filologia). Tver': Universidade estatal de Tver', 1999. KARASSIÓV, L.V. Gógol'v tékste (Gógol em texto). Moskvá: Znak, 2012.

KARTACHOVA, Irina. Gógol’ i Giugó (Gógol e Hugo). In MANN (Org.), 2003. KORÓVIN, V.I. (Org.). Istóriia rússkoi literatury XIX veka: v 3 tchastiákh (A história da literatura russa do século XIX: em três partes). Parte 2. Moskvá: Vládos, 2005.

KOTLIARÉVSKI, N. Nikolai Vassílievitch Gógol': Ótcherki iz istórii rússkoi póvesti i dramy (N. V. Gógol: os ensaios tirados da história da novela e do drama russos). Sankt-Peterburg: 1903, p. 106 Apud DMÍTRIEVA, 2011.

KRIVONÓS, V. Ch. Sny i probujdéniia v "Peterbúrgskikh povestiakh” Gógolia (Os sonhos e os despertares em 'Contos petersburgueses' de Gógol). In GONTCHAROV, S.A. (Org.), 1993.

\section{LEVENTAL’ V., DRUGOVÉIKO-DOLJÁNSKAIA S., KRUSSÁNOV P. (Org.).}

Literatúrnaia mátritsa. Utchébnik, napíssannyi pissáteliami (A matriz literária. Um livro didático escrito pelos escritores). Sankt-Peterburg - Moskvá: Limbus Press, 2011. LÉVTCHENKO, O.A. Prostránstvenno-vremennye otnochéniia v rússkoi romantítcheskoi ballade 20-30-kh godov XIX veka (As relações espaço-temporais na ballada russa romântica dos anos 20-30 do século XIX). In Rússkii romantizm: prostranstvo e vrémia (Romantismo russo: o espaço e o tempo). Dáugavpils: Izdátel'stvo Daugavpíllskogo pedagogítcheskovo universiteta, 1991.

LOBÁNOV, V.V. (org.) Biblioteka V. A. Jukóvskovo: opissánie (A biblioteca de Jukóvski: uma descrição). Tomsk: Universidade de Tomsk, 1981.

LÓTMAN, Iúri. Bessedy o rússkoi kul'ture (As conversas sobre a cultura russa). SanktPeterburg: Ázbuka, 2014. . O rússkoi literature. Stat'í i isslédovaniia (1958-1993) (Sobre a literatura russa. Os artigos e os estudos). Sankt-Peterburg: Iskusstvo-SPb, 1997. Utchébnik po rússkoi literature dliá srédnei chkoly (Um livro didático de literatura russa para o ensino médio). Moskvá: Iazykí rússkoi kul’tury, 2000. 
V chkole poetitcheskovo slova: Puchkin, Lérmontov, Gógol'. Kniga dliá utchítelia (Na escola da palavra poética: Púchkin, Lérmontov, Gógol. Um livro para um professor). Moskvá: Prosvechtchénie, 1988.

. "Zvoniátchi v prádedniuiu slavu” (Soando para a glória dos bisavôs). In .$O$ rússkoi literature. Stat'i i isslédovaniia (1958-1993) (Sobre a literatura russa. Os artigos e os estudos). Sankt-Peterburg: Iskusstvo-SPb, 1997.

MÁLKINA, Viktória. "Stráchnaia mest"” $i$ “Zámok Otranto” Uólpola ('A Terrível Vingança' e 'O castelo de Otranto' de Walpole). In TAMÁRTCHENKO, N.; ZÚSSEVA, V.; MÁLKINA, V. et. al. Gotítcheskaia traditsiia v rússkoi literature (Tradição gótica na literatura russa). Moskvá: Izdátel’ski Tsentr RGGU, 2008.

MANN, I.V. (Org.) Gógol’ kak iavlénie mirovoi literatury (Gógol como um fenômeno da literatura mundial). Moskvá: IMLI RAN, 2003.

Poètika Gógolia (A poética de Gógol). 2ª edição, complementada. Moskvá:

Khudójestvennaia literatura, 1978.

Proizvedénie, ne pokhójee na drugíe (Uma obra não parecida com as outras). In (Org.), 2003.

Rússkaia literatura XIX veka. Èpokha romantizma (A literatura russa do século XIX. A época do romantismo). Moskvá: RGGU, 2007.

. Usslojnénie romantítcheskovo mira v "Vetcherakh na khutore bliz Dikanki" (Uma complicação do mundo romântico em 'Noites em uma granja perto de Dikanka'). In 2007

Vstrétcha v labirinte. Frants Kafka i Nikolai Gógol' (Um encontro no labirinto. Franz Kafka e Nikolai Gógol). In Voprossy literatury, 1999, №2.

MATSAPURA, L. V. Gotitcheskaia traditsiia v póvesti Gógolia "Stráchnaia mest'”" (A tradição gótica na novela de Gógol 'A Terrível Vingança'). Disponível em:

http://www.domgogolya.ru/science/researches/1274/

MELETÍNSKI, E; NEKLIÚDOV, S.; NÓVIK, E. et. al. Struktura volchébnoi skazki (A estrutura do conto maravilhoso). Moskvá: RGGU, 2001.

MEREJKÓVSKI, Dmítri. Gógol’i tchiort (Gógol e o diabo). In GONTCHAROV (Org.), 2009

MODZALÉVSKII, L. Biblioteka Púchkina: Nóvye materialy (A biblioteca de Púchkin: os materiais novos). Moskvá: Jurnál'no-gazétnoe ob’edinénie, 1934. 
NABÓKOV, Vladímir. Gógol' (Gógol). Disponível em:

<http://gatchina3000.ru/literatura/nabokov_v_v/gogol.htm>.

NETCHIPÓRENKO, I. D. “Ryjie” ili “smechnye” liúdi na Ukraine: ot Gógolia do nachikh dnei (Os 'ruivos' ou os 'engraçados' na Ucrânia: de Gógol até os nossos dias). In Logítcheskii análiz iazyká. Iazykovye mekhanizmy komizma (A análise lógica da língua. Os mecanismos linguísticos da comicidade). Moskvá: Índrik, 2007.

ÓJEGOV, S.I. Slovar' rússkovo iazyká ( $O$ dicionário da língua russa). Moskvá: Rússkii Iazyk, 1990.

ORLÍTSKI, I. Sillabo-tonitcheskii metr v proze Gógolia (O metro sílabo-tônico na prosa de Gógol). In MANN (Org.), 2003.

PANTILÉEVA, A. I. (Org.) Sámye znamenitye chedévry gótiki (As obras-primas mais famosas do gótico). Moskvá: Belyi Górod, 2014.

PARFIÓNOV, A. T. Gógol' i barokko: "Igroki”" (Gógol e o barrocco: 'Os jogadores'). In Mirovoe drevo, 1996, №4.

POLIAKOVA, Angelina. Strukturoobrazúiuchtchaia rol' narodnovo kaliendariá v tsikle N.V. Gógolia "Vetcherá na khútore bliz Dikanki” (O papel estrutural do calendário popular na coletânea de N. V. Gógol 'Noites em uma granja perto de Dikanka'). Tese (Doutorado em filologia) Moskvá: Universidade estatal de Moscou de pedagogia (MPGU), 2008.

PÚCHKIN, A. S. Roman v pís'makh (O romance em cartas). In GÓRKI, M. BLAGÓI, D., BONDI, S. et. al. (Org.). __ Pólnoe sobránie sotchinénii v 16 tomakh (Obra completa em 16 tomos). Tomo VIII. Moskvá, Leningrad: AN SSSR, 1948.

RÓZANOV, V. V. Legenda o velíkom inkvizitore F. M. Dostoévskovo (O Grande Inquisidor de F. M. Dostoiévski). Moskvá: 1996.

SAMORÓDNITSKAIA, Ekaterina. "Británskoi muzi nebylitsy”: ob otnochénii Gógolia k gotitcheskim románam ('As invenções da musa britânica': sobre a atitude de Gógol aos romances góticos). In MANN (Org.), 2003.

. N.V. N.V. Gógol' i Tch. R. Mèt'iurin (Gógol e C. Maturin). In

TAMÁRTCHENKO, N., ZÚSSEVA, V., MÁLKINA, V. et.al. (Org.), 2008.

SEKÁTSKI, Aleksandr. Gógol' - otkrovénnoe i sokrovénnoe (Gógol-o revelado e o escondido). In LEVENTAL’ V., DRUGOVÉIKO-DOLJÁNSKAIA S., KRUSSÁNOV P. (Org.), 2011. 
SMIRNOV, I.P. Formirovánie i transformirovanie smysla v ránnikh tékstakh Gógolia ("Vetcherá na khútore bliz Dikanki”) (A formação e a transformação do sentido nos textos do jovem Gógol - Noites em uma granja perto de Dikanka). Russian literature, 1979, №7. SÓBOLEV, Lev. Netchístaia sila v Nótchi pered rojdestvom (vídeo) (A força impura em 'Noite de Natal'). Disponível em: <http://arzamas.academy/special/ruslit/episodes/20>. SOFRÓNOVA, L. A. Mifopoètika ránnevo Gógolia (A mitopoética do jovem Gógol). SanktPeterburg: Aleteiia, 2010.

STEPÁNOV, A.I. Gógol v “Otétchestvennikh zapískakh”, 1830 (Gógol na revista 'Otétchestvennye zapiski' em 1830). In Rússkaia literatura. Trudy otdiéla nóvoi rússkoi literaturi (Literatura russa. Os estudos obras do departamento da literatura russa nova). In GORODÉTSKI, PRUTSKOV, FRIDLÉNDER (Org.),1957.

Syn Otétchestva (revista), 1817, №18.

STRANO, G. Evropéiskie e rússkie literatúrnye istótchniki v tvórtcheskom protsesse Gógolia (As fontes literárias europeias e russas no processo criativo de Gógol) In MANN (Org.), 2003.

TAMÁRTCHENKO, N.; ZÚSSEVA, V.; MÁLKINA, V. et. al. Gotitcheskaia tradítsia v rússkoi literature (A tradição gótica na literatura russa). Moskvá: Izdátelskii Tsentr RGGU, 2008 .

TCHUDAKOV, G.I. Otnochénie tvórtchestva N.V. Gógolia k zapadnoievropéiskim literatúram (A relação da obra de Gógol às literaturas da Europa Ocidental). Kiev: 1908. TERTS, Abram. V tení Gógolia (Na sombra de Gógol). Disponível em: <http://modernlib.ru/books/arzhak_nikolay_terc_abram/v teni_gogolya/read $>$. TIAJIÓLOV, V. N. Isskusstvo srédnikh vekov (A arte da Idade Média). Moskvá: Izobrazítel'noe isskússtvo, 1993.

TOLSTÓI, L.N. Pólnoe sobránie sotchinéni v 90 tomakh (Obra completa em 90 tomos). Moskvá: Gosudárstvennoie izdátelstvo khudójestvennoi literatury, 1928-1958. Tomo 13. TZARYNNYI, Ándri. Mysli malorossiánina, po protchtiénii povestéi pásitchnika Rúdovo Panká, izdanykh im v knijke pod zagláviem: "Vietcherá na khútore bliz Dikanki”, i retsenzii na ónye (Os pensamentos do morador da Maloróssia, após a leitura das novelas do colmeeiro Rúdyi Pankó, publicadas sob o título 'Noites em uma granja perto de Dikanka', e das resenhas sobre esse livro). Sankt-Peterburg: Tipográfiia N. Gretcha, 1832. VATSURO, V.E. Gotítcheski roman v Rossii ( $O$ romance gótico na Rússia). Moskvá: Nóvoe literatúrnoe obozrénie, 2002. 
VERESSÁEV, V.V. Gógol'v jizni: Sistematitcheskii svod pódlinnykh svidétel'stv sovreménnikov (Gógol na vida: um conjunto sistemático das testemunhas verdadeiras dos contemporâneos). Prefácio de I. Zolotússki, preparação do texto e dos comentários de E. L Beznóssov. Moskvá/Leningrad: Academia, 1933.

VIKÚLOVA, V.P. (org.) N.V. Gógol'i sovriemiénnaia kul'tura: 6-e gogoliévskie thcténiia (Gógol e a cultura moderna: as 6as leituras gogolianas). Moskvá, KDU, 2007.

VINOGRÁDOV, V.V. Ízbrannye trudy. Poètika rússkoi literatury (Os estudos selecionados. A poética da literatura russa). Moskvá: Naúka, 1976.

ZALÓMKINA, G.V. Poètika prostranstva i vrémeni v gotitcheskom siujete (A poética do espaço e do tempo no enredo gótico). Samara: Samárskii universitet, 2006.

ZAMÁNOVA, Irada. Prostranstvo i vrémia v khudójestvennom mire sbórnika N.V. Gógolia “Vetcherá na khútore bliz Dikanki ( $O$ espaço e o tempo no mundo artístico da coletânea 'Noites em uma granja perto de Dikanka'). Tese (Doutorado em filologia). Oriól: Universidade Estatal de Oriól, 2000.

ZASSLÁVSKI, Oleg. Zámyssel 'Gét'mana': rekonstrúktsiia siujeta i kompozitsii (A ideia de 'Hetman': uma reconstrução do enredo e da composição). In MANN (Org.), 2003 ZOLOTÚSSKI I. P. Gógol' (Gógol). - 5ª edição. Moskvá: Molodáia Gvárdiia, 2005.

\section{Bibliografia sobre Gógol, teoria e crítica literária em outros idiomas}

AVSEY, Ignat. The Gothic in Dostoevskii and Gogol: the British connection. In CORNWELL, Neil (Org.). The Gothic-fantastic in Nineteenth-century Russian literature. Amsterdam - Atlanta: Rodopi, 1999.

BAKER, Ernest A. The history of the English novel. Vol.5: The novel of sentiment and the Gothic romance. London: H.F. \& G. Witherby, 1942.

BAYER-BERENBAUM, Linda. The Gothic imagination: Expansion in Gothic literature and Art. London: Farleigh Dickinson University Press, 1982.

BOTTING, Fred. Gothic. London: Routledge, 1996.

CHAUNCEY, Finch E. Classical influence on N.V. Gogol. In: The Classical Journal, Vol. 48, №8 (May, 1953).

CHAPIRO, Gavriel. Nikolai Gogol' and the Baroque Heritage. In Slavic Review, Vol. 45 №1 (Spring 1986).

CLERY, E.J. The genesis of “Gothic” fiction. In HOGLE (Org.), 2002. 
CORNWELL, Neil (Org.). The Gothic-fantastic in Nineteenth-century Russian literature. Amsterdam - Atlanta: Rodopi, 1999.

COX, Gary. Geographical, sociological and sexual tensions in Gogol's Dikan'ka stories. In Slavic and East European journal. Bd. 24. 3. Fall 1980.

ERLANDE-BRANDENBURG, Alain. L'art gothique. Paris: Citadelles \& Mazenzod, 2004. FISHER, Benjamin Franklin. Poe and the gothic tradition. In HAYES (Org.), 2002.

GAMER, Michael. Gothic fictions and Romantic writing in Britain.In HOGLE (Org.), 2002. HAGGERTY, George H. Gothic Fiction / Gothic Form. The Pennsylvania State University Press: University Park and London, 1989.

HALE, Terry. French and German Gothic: the beginnings. In: HOGLE (Org.), 2002. HAYES, Kevin (Org.). The Cambridge companion to Edgar Allan Poe. New York: Cambridge University Press, 2002.

HOGLE, Jerrold E. (Org.) The Cambridge Companion to Gothic fiction. New York: Cambridge University Press, 2002.

HOLQUIST, James M. The Devil in Mufti: The Märchenwelt in Gogol's Short Stories. In PMLA, Vol. 82, n.5 (Oct., 1967).

HOWARD, Jaqueline. Reading Gothic fiction: A Bakhtinian Approach. Oxford: Clarendon Press, 1994.

KASTAN, David Scott (Org.). The Oxford Encyclopedia of British Literature. Oxford: Oxford University Press, 2005, tomo 4.

MEYER, Priscilla. Supernatural Doubles: Vii and The Nose. In CORNWELL, Neil (Org.), 1999.

MILES, Robert. The 1790s: the effulgence of Gothic. In HOGLE (Org.), 2002.

PUNTER, David. A companion to the Gothic. Oxford: Blackwell Publishing, 2000.

PUTNEY, Christopher. Russian Devils and Diabolic Conditionality in Nikolai Gogol's

Evenings on a Farm near Dikanka. New York: Peter Lang, 1999.

RADCLIFFE, Ann. The Novels. Complete in one volume. New York: Georg Olms Verlag Hildesheim, 1974.

ROBERTS, L. M. Literary nationalism in German and Japanese Germanistik. Peter Lang, 2010.

SCOTT, Walter. Prefatory Memoir to Mrs. Ann Radcliffe. In The novels of Mrs. Ann Radcliffe. London. Hurst, Robinson and Co. 1824. Disponível em: 
<http://books.google.ru/books?id=831EAAAAcAAJ\&printsec=frontcover\&source=gbs_ge_su mmary_r\&cad $=0 \# v=$ onepage $\& q \& \mathrm{f}=$ false $>$.

SIMMONS, E.J. Gogol and English Literature. In The Modern Language Review, Vol. 26, №4 (Oct., 1931).

SIMPSON, Mark S. The Russian Gothic novel and its British antecedents. Ohio: Slavic Publishers, 1986.

SOBEL, Ruth. Time, space and genre in Gogol's 'Mirgorod'. In Essays in Poetics: The Journal of the British Neo-formalist circle, April 1981 vol. 4 №1. UK: Univ. of Keele. SPACKS, P.M. Horror-Personification in late 18 Century Poetry. In Studies in Philology, 1962, Vol. 59, №3.

SUMMERS M. The Gothic Quest: A History of the Gothic Novel. New York: Russel\&Russel, 1964.

TRACY, Ann B. The Gothic Novel, 1790-1830. Lexington: University of Kentucky, 1981. VARMA, Devendra P. The Gothic Flame. London: The Scarecrow Press, 1987.

WALPOLE, Horace. The Castle of Otranto, a Gothic Story. The third edition. London: Printed for John Murray, Successor to Mr. Sandby, №32, Fleet-street, 1769. Disponível em: $<$ https://play.google.com/books/reader?printsec=frontcover\&output=reader\&id=QiAGAAAA QAAJ\&pg=GBS.PR3>.

ZACHARIAS-LAGHANS, G. Der Unheimliche Roman um 1800. Bonn: 1968. 